\title{
History and geochemical evolution of igneous rocks forming the Panama land bridge since Late Cretaceous
}

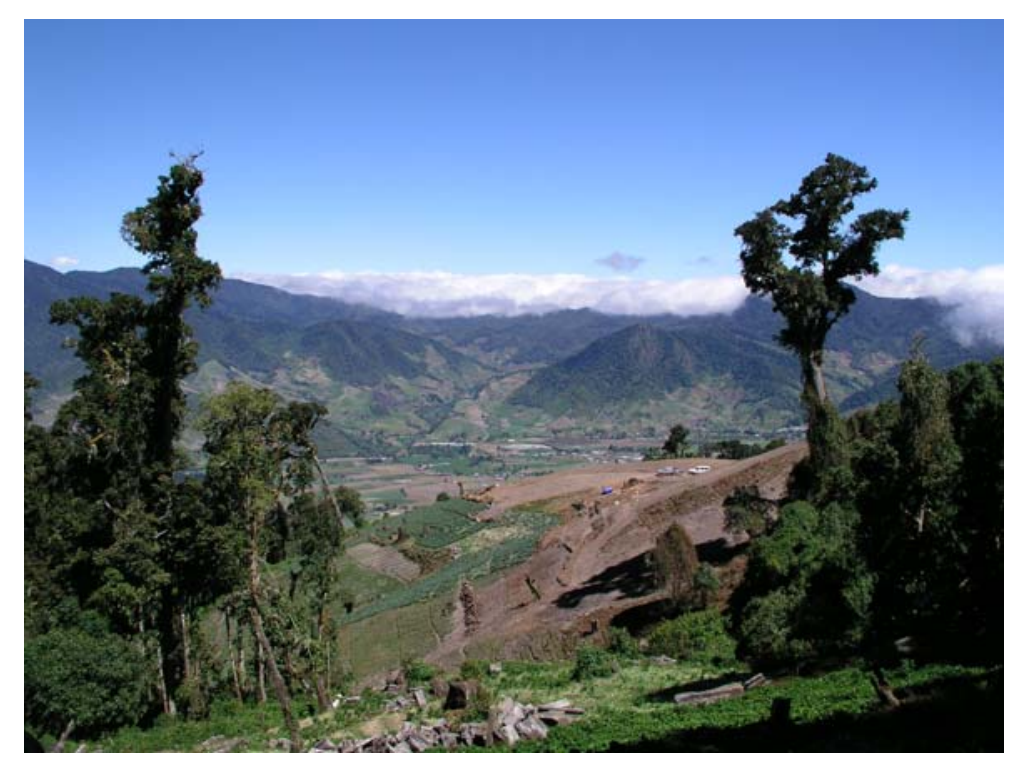

\author{
Dissertation \\ zur Erlangung des Doktorgrades \\ der Mathematisch-Naturwissenschaftlichen Fakultäten \\ der Georg-August-Universität zu Göttingen
}

vorgelegt von

Wencke Wegner

aus Mannheim

Göttingen 2011 
D7

Referent: Prof. Dr. Gerhard Wörner

Korreferent: Prof. Dr. Bent Hansen

Tag der mündlichen Prüfung: 
„Überall geht ein frühes Ahnen dem späteren Wissen voraus.“

Alexander von Humboldt

Für Anne,

die immer an mich geglaubt hat, aber den Glauben an sich selbst verlor. 


\section{Acknowledgments}

'Oh wie schön ist Panama...' (Janosch, 1978) ... and how complex and interesting I would like to add to these words. On my way to understand the evolution of Panama I had many companions who were on hand with help and advice and in times of trouble they showed me the right way.

In the first place I would like to thank my doctoral advisor Gerhard Wörner who gave advice and support to me and he never grew tiered of presenting new ideas and approaches how to solve the open questions. He taught me, that even unsatisfactory results can contribute to the solution of a problem as long as they are interpreted and discussed sufficiently.

Special thanks to all staff members of the division of Geochemistry, who supported me at any time and had a sympathetic ear form my ideas as well as a prompt date of measurement for my samples. Thanks to Ingrid Reuber who introduced and supported me in the clean lab. Particular thanks to Stefan Möller who solved my recurrent IT-problems with a considerable amount of patience.

I have furthermore to thank the Isotope geology section for using the mass spectrometers and the friendly and qualified assistance during measurements.

I would like to thank Russell Harmon for inspiring oxygen isotope discussions and support as well as the best field work I ever had.

Thanks to the staff member of the Rare Gas Geochronology Laboratory at the University of Wisconsin-Madison and specially Brian Jicha for measuring my $\mathrm{Ar} / \mathrm{Ar}$ data.

Many thanks to my colleges from the "mensa team“ and the "Kaffeerunde“ representing my social background. Informal conversation about the meaning of life and diverse anecdotes provided an agreeable social climate. Additional sport events like bowling and skiing made things much easier.

Last but not least I would like to thank my friends and my family. Financial and moral support of my parents as well as loyalty and flexibility of my sister and my friend, made me finish this study. 


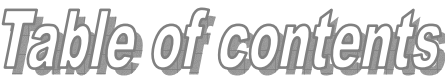

Acknowledgments

Index of figures and tables. IV

Abstract / Zusammenfassung. VII ohe⿴囗玉

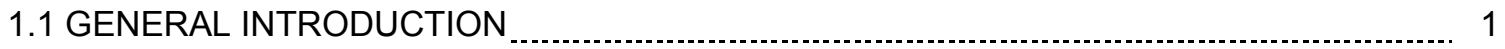

1.1.1 The Rio Chagres Project ............................................................................... 1

1.1.2 Subduction Zone Arc Magmatism ........................................................ 2

1.2 GEOLOGICAL BACKGROUND

1.3 OUNTLINE OF THIS STUDY

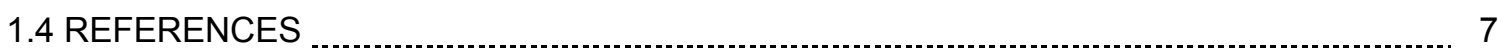

ohtents

2.1 SAMPLE COLLECTION

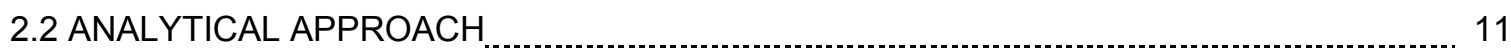

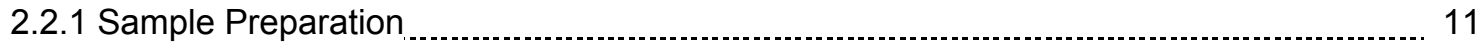

2.2.2 X-ray Fluorescence Spectroscopy (XRF) ......................................................... 12

2.2.3 Inductive Coupled Plasma Mass Spectrometry (ICP-MS)....................................... 13

2.2.4 Thermal Ionization Mass Spectrometry (TIMS) ................................................... 13

2.2.5 Dual inlet Gas-source Mass Spectrometry ........................................................ 14

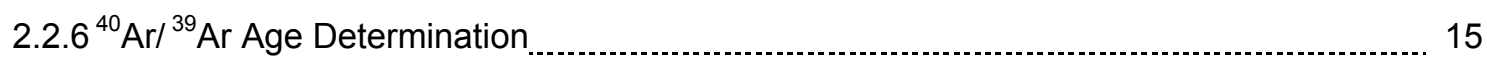

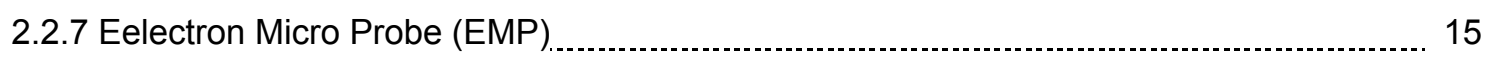

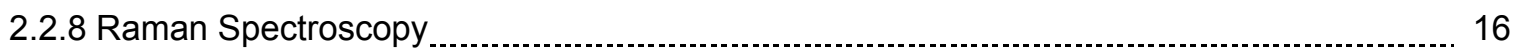

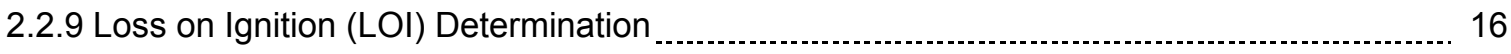

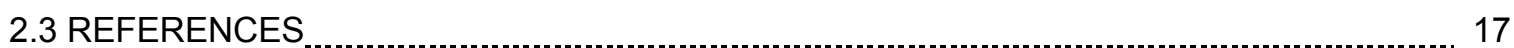

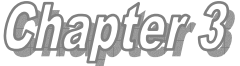

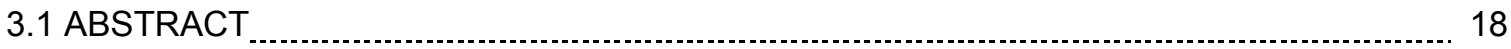

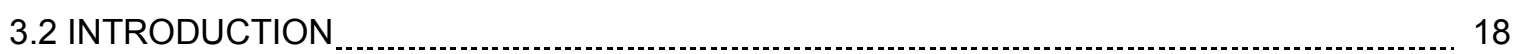

3.2.1 The Chagres Igneous Complex................................................................... 18

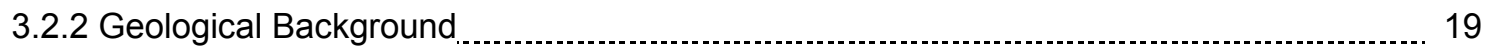

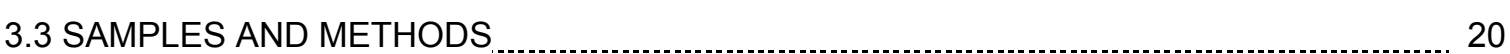

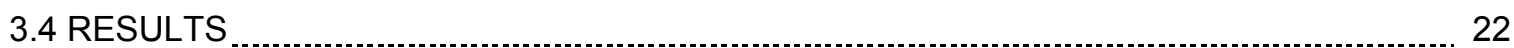

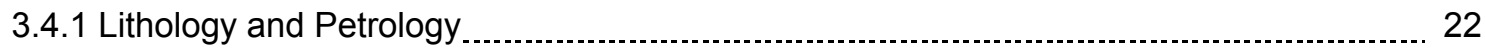

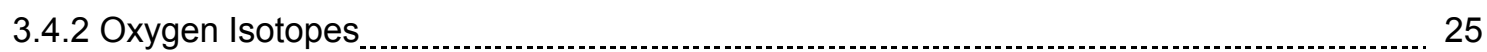

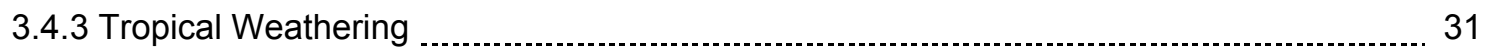

3.4.4 Major Elements versus Alteration Proxies ....................................................... 32

3.4.5 Trace Element variations due to Source variation, Slab fluid and Alteration ................ 36

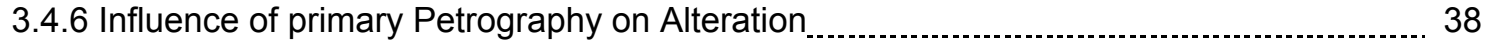

3.5 DISCUSSION

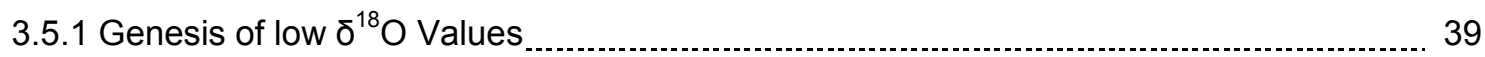


3.5.2 Evolution of the different Alteration Types $\ldots 40$

3.5.3 No Correlation between Elemental Composition and Alteration Proxies _...................... 42

3.5.4 Oxygen Isotopes as Tracer for multiple Alteration Events .................................... 43

3.5.5 Implications of Alteration for Interpretations of Mantle Sources ................................. 45

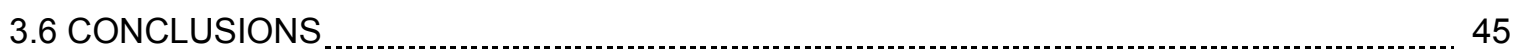

3.7 REFERENCES

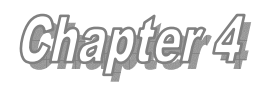

4.1 ABSTRACT

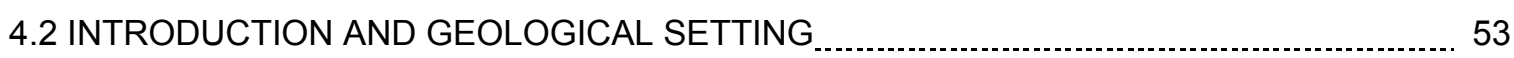

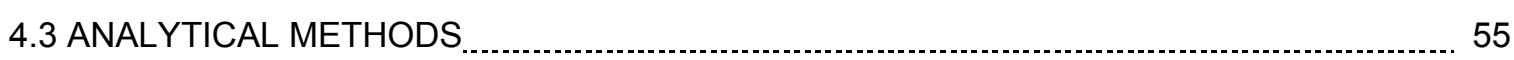

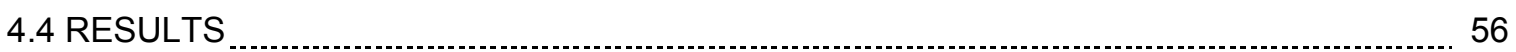

4.4.1 Age, Composition and Mantle Source of CLIP Terranes ......................................... 61

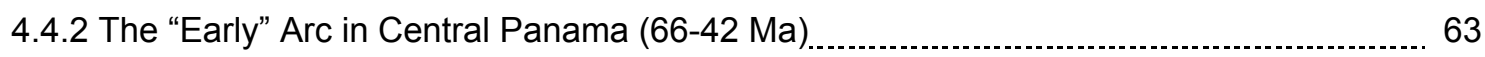

4.4.3 The Miocene Arc (36 to $5 \mathrm{Ma}) \ldots$

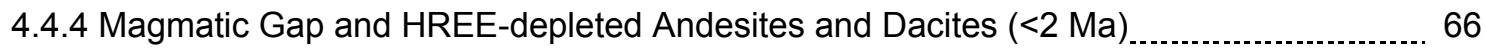

4.5 DISCUSSION: CHANGING MANTLE SOURCES THROUGH TIME _......................... 68

4.6 SUMMARY AND CONCLUSIONS ................................................................... 71

4.7 REFERENCES

Che

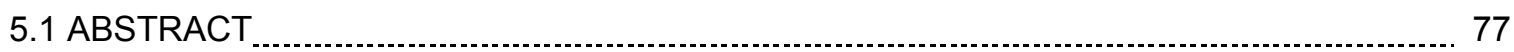

5.2 INTRODUCTION AND GEOLOGICAL SETTING ..................................................... 77

5.3 SAMPLE COLLECTION AND ANALYTICAL METHODS ............................................ 81

5.4 RESULTS AND DISCUSSION

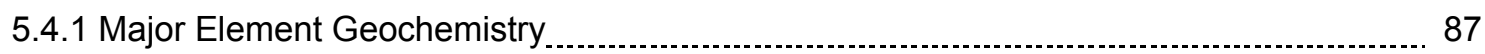

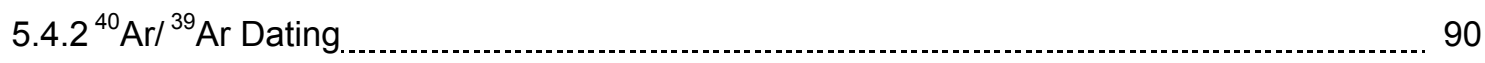

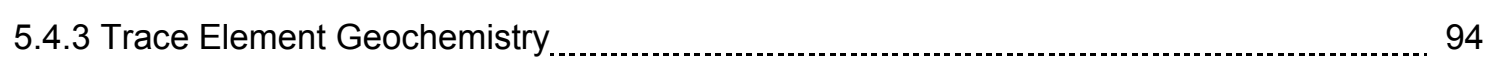

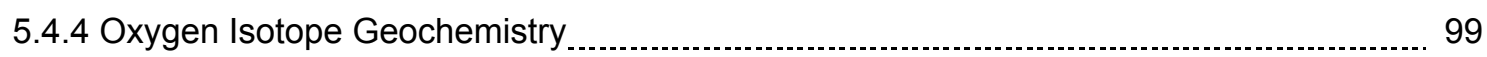

5.4.5 Temporal History of Radiogenic Isotope Variations _............................................ 109

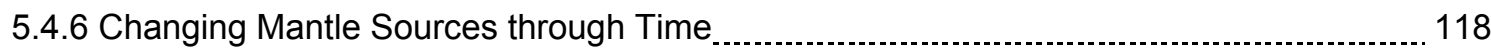

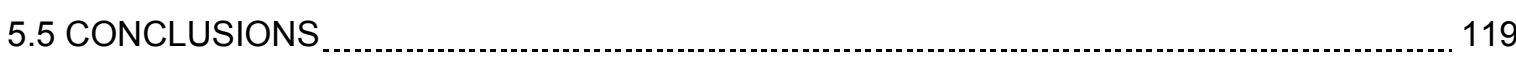

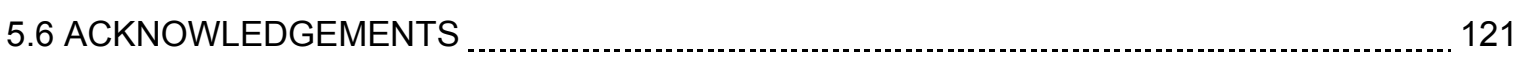

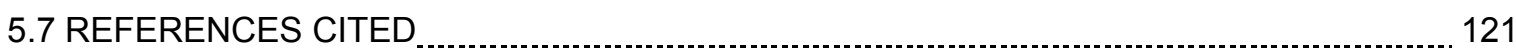

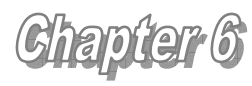

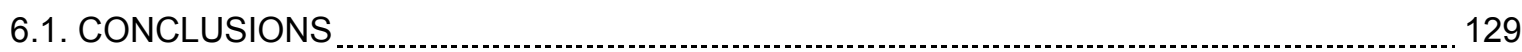

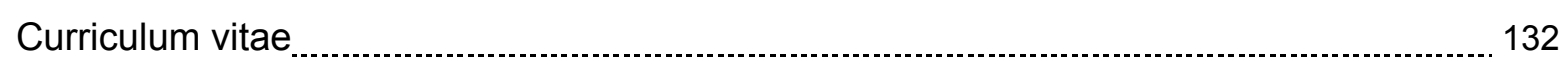

Appendiry provided on $C D$
I. Sample Regions Panama
II. Full Data Table
III. Complete Ar-results 


\section{Index of figures and tables}

\section{Chaperient}

Figure 1.1. Reconstruction of the tectonic evolution of the Central American land bridge from late Cretaceous to present

Figure 1.2. DEM (digital elevation model) map of Panama showing the location of the different magmatic arcs

\section{Chatenter?}

Figure 2.1. DEM (digital elevation model) map of Panama showing the geographic distribution of the samples analysed for this study

\section{C.}

Figure 3.1. Topographic map section of Panama showing the location of the samples taken from the Chagres igneous complex (CHICO)

Figure 3.2. Schematic sketch of the Chagres Volcanic Complex a submarine edifice based on the rock units found in the area of the Rio Chagres Basin

Figure 3.3. Photomicrographs of different alteration phenomena in studied rocks

Figure 3.4. Histogram of $\delta^{18} \mathrm{O}$ values illustrating the $\mathrm{O}$-isotope variation

Figure 3.5. Plot of $\delta^{18} \mathrm{O}$ values versus $(A)$ silica content and $(B)$ water content of the whole rock

Figure 3.6. Chemical classification and nomenclature of volcanic rocks

Figure 3.7. Variation of major element ratios relative to the two alteration proxies water content and positive $\Delta^{18} \mathrm{O}$ measured-pristine

Figure 3.8. Trace element patterns, for all analysed samples from the $\mathrm{CHICO}$

Figure 3.9. Photomicrographs of two fresh minerals without alteration aspects and solution-precipitation signs however characterized by low $\delta^{18} \mathrm{O}$ values

Figure 3.10. Schematic sketch showing the two stage process of the formation of the observed $\delta^{18} \mathrm{O}$ values

Figure 3.11. Plot of $\mathrm{Al}_{2} \mathrm{O}_{3}$ versus $(\mathrm{A}) \mathrm{TiO}_{2}$ and (B) $\mathrm{CaO}$ in pyroxenes, amphiboles and chlorites

Figure 3.12. Plot of $\mathrm{H}_{2} \mathrm{O}$ versus the the $\Delta^{18} \mathrm{O}$ measured-pristine

Table 3.1. Petrographic composition of the different samples used for alteration investigations

Table 3.2. Oxygen - isotope composition of minerals and whole rock as well as fresh values calculated following the procedure of Bindeman et al. (2004) as explained in the text

Table 3.3. Major, minor and trace element bulk rock composition 


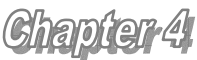

Figure 4.1. Plate-tectonic setting of the Central American land bridge 54

Figure 4.2. Map of Panama showing the sample locations of this study

Figure 4.3. Total Alkali - Silica diagram for the volcanic and intrusive rocks from central and western Panama analyzed in this study

Figure 4.4. Chondrite-normalized trace element patterns for volcanic and intrusive rocks from central and western Panama

Table 4.1. Major- and trace-element composition of representative sample

\section{Shaverter}

Figure 5.1. Tectonic setting of the Central America Land Bridge region

Figure 5.2. Topographic map of Panama showing the locations and volcanic features referred to in the text and the geographic distribution of the samples

Figure 5.3. Chemical classification and nomenclature of volcanic rocks displayed in total alkali versus silica (TAS) diagram

Figure 5.4. Subdivision of subalkaline rocks after Rickwood (1989) based on the basis of $\mathrm{K}_{2} \mathrm{O}$ versus silica content

Figure 5.5. Age distribution of CLIP rocks and Galápagos-derived seamounts and age distribution of arc rocks in central and western Panama and in southern Costa Rica

Figure 5.6. Trace element patterns, normalized to primitive mantle (Sun and McDonough 1989), for igneous rocks from central and western Panama

Figure 5.7. Plot of $\mathrm{Ta} / \mathrm{Yb}$ versus $\mathrm{Th} / \mathrm{Yb}$ for magmatic rocks from central and western Panama.

Figure 5.8. Plot of chondrite normalized ratios of $\mathrm{La} / \mathrm{Nb}$ versus $\mathrm{Nb} / \mathrm{Zr}$

Figure 5.9. Histogram of $\delta^{18} \mathrm{O}$ values illustrating the $\mathrm{O}$-isotope variation in (A) feldspar, (B) pyroxene, and (C) amphibole for Panamanian igneous rocks

Figure 5.10. Plot of mineral ${ }^{87} \mathrm{Sr} /{ }^{86} \mathrm{Sr}$ versus $\delta^{18} \mathrm{O}$ for $(\mathrm{A})$ amphibole and pyroxene and $(B)$ feldspar for Panamanian igneous rocks

Figure 5.11. Histogram comparing $\delta^{18} \mathrm{O}$ values Panamanian adakites $(A)$ with those from Costa Rica (B) analyzed by Abratis (1998) and various locations worldwide including Panama (C) analyzed by Bindeman et al. (2005)

Figure 5.12. Plot of $\mathrm{Pb}-, \mathrm{Nd}$-, and $\mathrm{Sr}$-isotope ratios for igneous rocks from central and western Panama over the past 80 million years

Figure 5.13. Plots of initial $\mathrm{Sr}-$, $\mathrm{Nd}$ - and $\mathrm{Pb}$ - isotope ratios for magmatic rocks of western and central Panama 
Table 5.1. Summary of ${ }^{40} \mathrm{Ar} /{ }^{39} \mathrm{Ar}$ incremental-Heatig experiments

Table 5.2. O-isotope compostion of minerals and $\delta^{18} \mathrm{O}_{\text {magma }}$ values calculated following the procedure of Bindeman et al. (2004) 101

Table 5.3. Ranges of $\delta^{18} \mathrm{O}$ variation for Panamanian igneous rocks 102

Table 5.4. Initial and measured $\mathrm{Sr}$ - and $\mathrm{Nd}$ - isotopic composition for separated minerals

Table 5.5. Initial and measured $\mathrm{Pb}$ - isotopic composition for separated minerals

\section{Ch:}

Figure 6.1. Schematic sketch of the arc evolution of south Central America between the Late Cretaceous and today 


\section{Abstract}

Major and trace elements, Sr-, Nd-, $\mathrm{Pb}$-, and O-isotopes and ${ }^{40} \mathrm{Ar} /{ }^{39} \mathrm{Ar}$ dating of igneous rocks from the Cordillera de Panama and the Soná and Azuero Peninsulas define the magmatic evolution over the last $95 \mathrm{Ma}$ in western Panama. An initial phase of intraplate magmatism derived from a Galápagos-type plume source and forms the Caribbean Large Igneous Province basement at 95-69 Ma. Younger accreted terranes with enriched trace element patterns were amalgamated between 71 and $21 \mathrm{Ma}$. A distinct magmatic suite in the Soná and Azuero Peninsulas shows trace element patterns suggesting the initiation of subduction at 71-68 Ma (SonáAzuero arc). Arc magmatism continues in the cordillera with a first pulse between 66 and $61 \mathrm{Ma}$ in the Chagres and Bayano area and a second pulse from 50 to $42 \mathrm{Ma}$ (Chagres-Bayano arc). A third phase of younger arc magmatism started after a significant magmatic gap of about $20 \mathrm{Ma}$ from 19-7 Ma along the whole Cordillera de Panama (Cordilleran arc). The youngest magmatic phase consists of isolated volcanic centers of adakitic composition in the Cordillera de Panama that developed over the last $2 \mathrm{Ma}$ (Adakite suite).

Initiation of arc magmatism at $71 \mathrm{Ma}$ coincides with the cessation of Galápagos plateau formation, which insicates a causal link. The transition from intraplate to arc magmatism occurred relatively fast ( $3 \mathrm{Ma}$ ) and introduced a new enriched mantle source. The transition between early Chagres-Bayano arc and younger Cordilleran arc (41 to $19 \mathrm{Ma}$ ) involves a change to more homogeneous intermediate mantle wedge compositions through mixing and homogenisation of sub-arc magma sources through time and/or the replacement of the mantle wedge by a homogeneous, relatively undepleted asthenospheric mantle. The break-up of the Farallon plate at this time ( $25 \mathrm{Ma})$ may have triggered these changes. Adakite volcanism started after a magmatic gap, enabled by the formation of a slab window.

The validity of these results is supported by alteration studies. Even though strong petrographic evidence for alteration and new growth of minerals is found, the compositional and isotopic systematics are changed relatively little by hydrothermal alteration at variable temperatures and diverse water-rock ratios. Therefore source composition determinations are possible as long as oxygen isotopes are used as tracers even if the samples are affected by alteration. 


\section{Zusammenfassung}

Anhand von Haupt- und Spurenelemente, Sr-, $\mathrm{Nd}-, \mathrm{Pb}-$, und O-isotope sowie ${ }^{40} \mathrm{Ar} /{ }^{39} \mathrm{Ar}$ Datierungen von magmatischen Gesteinen aus der Cordillera de Panama und von den Halbinseln Soná und Azuero, wird die magmatische Entwicklung von West-Panama über die letzten $95 \mathrm{Ma}$ beschrieben. Eine initale Phase von Intraplatten-Magmatismus, mit einer Galápagos-typ Plumesignatur formte das „Caribbean Large Igneous Province“ Grundgebirge zwischen 95 und 69 Ma. Junge akkretionierte Terrane mit angereicherten Spurenelementmustern wurden zwischen 71 und $21 \mathrm{Ma}$ an den Plateaurand angeschlossen. Eine klar ausgeprägte magmatische Serie von den Halbinseln Soná und Azuero zeigt Spurenelementsignaturen die den Beginn der Subduktion auf 71-68 Ma festlegen (SonáAzuero arc). Der Subduktionszonen-Magmatismus hält an und verlagert sich in das Chagres und Bayano Gebiet in der Cordillera de Panama (Chagres-Bayano arc). Diese Phase ist durch 2 Schübe/Pulse gekennzeichnet, von denen der erste von 66-61 Ma und der zweite von 50 bis $41 \mathrm{Ma}$ auftrat. Eine dritte Phase von jungem Subduktionszonen-Magmatismus begann nach einer prominenten magmatischen Lücke (20 Ma) entlang der Cordillera und dauerte von 19-7 Ma (Cordilleran arc). Die jüngste magmatische Phase besteht aus isolierten vulkanischen Zentren mit adakitischer Zusammensetzung die entlang der Cordillera verteilt sind (Adakite suite). Diese Phase entwickelte sich in den letzten $2 \mathrm{Ma}$.

Da die Initiierung des Subduktionszonen-Magmatismus vor 71 Ma mit dem Ende der Galápagos-Plateaubildung zusammen fällt, liegt ein Zusammenhang nahe. Der Übergang von Intraplatten- zu Subduktionszonen-Magmatismus verlief relativ schnell (3 $\mathrm{Ma}$ ) und beinhaltete eine neue angereicherte Mantelquelle. Der Übergang zwischen dem ChagresBayano arc und dem jüngeren Cordilleran arc (41 bis $19 \mathrm{Ma}$ ) ist charakterisiert durch die Bildung eines homogeneren intermediären Mantelkeils, der entweder durch Mischung und Homogenisierung der Subarc-Quelle mit der Zeit und/oder Austausch des Mantelkeils durch einen homogenen und relativ unverarmten asthenosphärischen Mantel entstanden ist. Das Auseinanderbrechen der Farallon Platte zu dieser Zeit $\left(\begin{array}{ll}\sim & \mathrm{Ma}\end{array}\right)$ könnte diese Veränderungen ausgelöst haben. Adakite Vulkanismus setzte nach einer magmatischen Lücke ein, ermöglicht durch die Bildung eines so genannten „slab window“.

Die Gültigkeit dieser Ergebnisse wird durch Alterationsstudien unterstützt. Obwohl deutliche petrographische Beweise für Alteration und Mineralneubildungen gefunden wurden, sind sowohl die Element-Zusammensetzung als auch die Isotopensysteme relativ wenig durch hydrothermale Alteration, bei unterschiedlichen Temperaturen und verschiedenen WasserGestein-Verhältnissen, beeinflusst. Auf Grund dessen ist die Bestimmung der Zusammensetzung der Magmenquellen, solange Sauerstoffisotope als Tracer verwendet werden, möglich, auch wenn die Proben alteriert sind. 


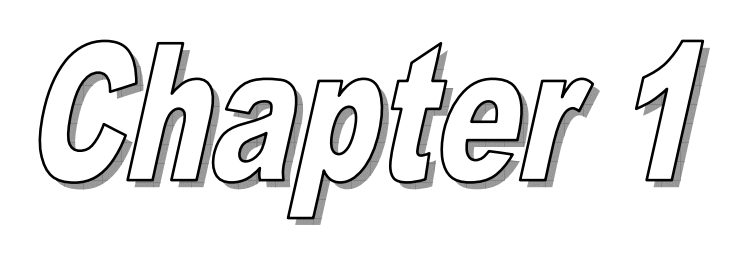

Introduction and geological setting 


\subsection{GENERAL INTRODUCTION}

\subsubsection{The Rio Chagres Project}

Over the last $70 \mathrm{Ma}$, the Central American land bridge is a "hot spot" of fundamental changes over the last $70 \mathrm{Ma}$ which affected large areas of the world (e.g. Maury et al., 1995). The arrival of the Caribbean plateau in the position of the today's Azuero and Soná peninsula led to the development of a volcanic arc system which builded and eventually closed the Central American land bridge ca. $3 \mathrm{Ma}$ ago (Haug and Tiedemann, 1998). This newly formed narrow landmass facilitated flora and fauna to exchange between the Americas. On the other hand the pathway from ocean to ocean was closed. As an outcome of this, e.g. Haug et al. (2001) showed differences between Pacific and Atlantic developed in terms of foraminifera population, sea level (Atlantic $\sim 0.7 \mathrm{~m}$ below the Pacific) and salinity (Atlantic: $3.54 \%$; Pacific: $3.45 \%$ ). In addition new ocean currents were formed leading to global climatic changes (e.g. Pliocene warm period followed by northern hemisphere glaciations).

Today the Panama region is still of special interest and global importance, less in an ecologic than in an economic way. The Panama Canal is one of the most important artificial water ways in the world. In April 2006 the enlargement of the canal was initiated. Until 2014 the canal will be broadened and new locks will double today's capacity. Prior to these works the international, multidisciplinary "Chagres project" was founded. The aim of this project is to characterise the Rio Chagres basin, the main water supplier for the Panama Canal, in terms of biology, soil science, meteorology, hydrology, remote sensing and geology (Harmon, 2005). In special focus are the quantification of hydrologic processes and the modelling of flow dynamics with regard of sediment transport toward the Canal Zone. For these topics lithology is a key information in terms of erosion potential, river profiles and runoff dynamics. Therefore petrological and geochemical analyses were carried out to investigate the magmatic basement of the Chagres basin. In addition to this submarine oceanic island complex called "Charges Igneous Complex" other samples were taken along the Cordillera de Panama from the border to Costa Rica in the west to the Bayano area in the east to define the magmatic history of the Central American land bridge in Panama through time. 


\subsubsection{Subduction Zone Arc Magmatism}

Subduction zones and related arc magmatism are of scientific interest for a long time already. They are studied world wide with the main focus on "the ring of fire" around the Pacific Ocean (e.g. Brantly, 1994). Subduction zones are regions of destruction of oceanic crust but more dominant of production of new continental crust. These processes are the essence for continental build up. In the special tectonic case of the Central American subduction zone the formation of a preliminary island arc and then a new continental arc led to the formation of a land bridge between North and South America. As a consequence the ocean currents changed accompanied by climatic changes along the globe. This process of land bridge formation occurred between 6.2 and 3.5 Ma (Duque-Caro, 1990; Coates et al., 1992, 2000; Collins et al., 1996; Haug et al., 2001). However the origin of uplifted basaltic crust started much earlier with the beginning of the formation of the Caribbean Large Igneous Province (CLIP) at around $139 \mathrm{Ma}$ (Hoernle et al., 2004). During this long time period several tectonic rearrangements took place and as a consequence different magmatic phases fed from different mantle sources contributed to the genesis of the magmatic arc. Geochemical studies in this region so far dealt either with the origin of the CLIP basement and younger mafic complexes (Goossens et al., 1977; Hauff et al., 1997, 2000; Hoernle et al., 2002, 2004; Hoernle and Hauff, 2007) or the formation of Quaternary volcanic centers (de Boer et al., 1988, 1995; Defant et al., 1991a, 1991b; Drummond et al.; 1995; Abratis und Wörner, 2001; Carr et al., 2003). Only scant attention existed to link the CLIP basement with the younger volcanic arc phases (de Boer et al., 1988, 1995).

Based on major and trace elements, age data and isotope data this study fills this gap of knowledge. It will describe the different arc magmatic phases starting at around $70 \mathrm{Ma}$ and developing until today and link them to their specific magma sources. In addition the origin and composition of the different magma sources will be characterized. Associated tectonic events will be described and their influences on magma genesis will be constrained. Furthermore using the example of the Chagres igneous complex ( $\mathrm{CHICO}$ ) alteration processes of magmatic arc rocks in a submarine and tropical environment will be characterized. Based on the alteration results the consistence of the isotope and geochemical data and following conclusion will be shown. 


\section{2 GEOLOGICAL BACKGROUND}

Most of the volcanoes of the world are related to subduction of oceanic crust forming volcanic arcs. Arc magmatism is restricted to active convergent continental and oceanic margins where an oceanic plate is subducted beneath a continental or oceanic one. Released slab fluids in specific depths lead to melting of the overlying mantle wedge. Resulting magma rises and creates plutonic intrusions or volcanic eruptions near or on the surface. In the case of present day Central America the Nazca and Cocos plate are subducted in an eastward dipping subduction zone beneath the Caribbean plate. In Panama the subduction zone is blocked and the plate movements are taken up by thrust movement in the northern and eastern Panama deformed belt (Mann and Kolarsky, 1995). Therefore, no active arc magmatism along Panama in recent times exists. Only in the very west volcan Baru shows adakitic volcanism in historic time.

The history and geological evolution of the land bridge in this work will be considered from ca. $70 \mathrm{Ma}$ ago starting with the formation of the Soná -Azureo arc. The oldest sample dated here is a $71 \mathrm{Ma}$ old dacite from the Azuero peninsula. However the evolution of the rock units that form the land bridge today started earlier with the formation of the Caribbean Large Igneous Province (CLIP, Hoernle et al., 2004). This overthickened oceanic plateau formed in the region of the today's Galápagos hot spot, moved eastward and reached the position of the present Caribbean Plate between northern South America in the south and the Chortis Block in the north in the Campanian (Fig.1.1). Subduction and associated arc magmatism at its newly formed western margin started at $\sim 71 \mathrm{Ma}$ in the region of Soná and Azuero peninsulas. This arc magmatism continues for $\sim 5 \mathrm{Ma}$ and then moved towards the present day Chagres and Bayano area (Fig. 1.1, 1.2). This arc magmatism lasted $\sim 25 \mathrm{Ma}$ and after a period of magmatic lull arc magmatism commenced along the Cordillera de Panama at $\sim 22 \mathrm{Ma}$. This is a consequence of the break up of the Farallon plate into the Cocos and Nazca plate slightly earlier at $\sim 25 \mathrm{Ma}$ (Barckhausen et al., 2008). During the time of convergence Galápagos seamounts accreted to the margin (Hauff et al., 1997, 2000; Hoernle et al., 2002; Buchs et al., 2010). The collision of the Panama block with the South American plate around 13-7 Ma (Coates et al., 2004) or 25-23 Ma (Farris et al., 2011) led to uplift and bending of the orogen. 

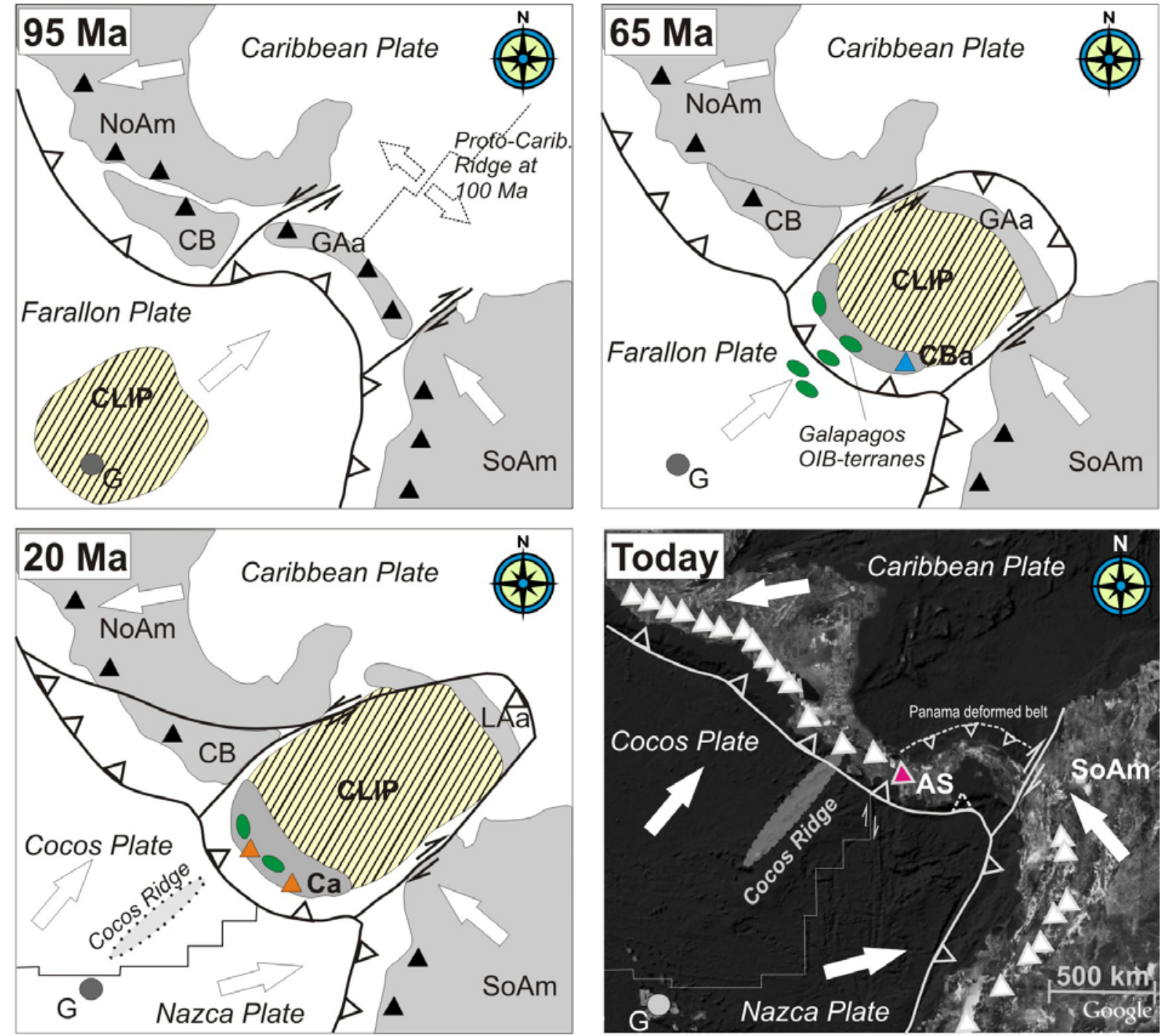

Figure 1.1. Reconstruction of the tectonic evolution of the Central American land bridge from late Cretaceous to present (based on Mann et al., 2007; Pindell et al., 2006, and respective references there in). Bold arrows indicate direction of plate motion. NoAm-North America, SoAm-South America, CB-Chortis Block, CLIP-Caribbean large igneous province, G-Galápagos hot spot, GAa-Greater Antilles arc, LAa-Lesser Antilles arc, OIB-Ocean island basalt, CBa-ChagresBayano arc, Ca-Cordilleran arc, AS-Adakite suit.

The formation of different fault systems, the Panama Canal Zone fault in the west, the northern and southern Panama deformed belt, and the Atrato fault in the east enabled the movement of the Chocó block to the north relative to the stable Chorotega Block. 'Normal' arc magmatism stopped in the upper Miocene and is followed by a magmatic gap in the region of western Panama for 2-3 Ma. During this time the cessation of spreading in the Panama Basin took place (Lonsdale and Kilgord, 1978) and the isthmus closed between 6.2 and 3.5 Ma (Duque-Caro, 1990; Coates et al., 1992; Collins et al., 1996; Haug et al., 2001; Coates et al., 2000). 
These tectonic rearrangements are accompanied by choked subduction. However at around $2 \mathrm{Ma}$ isolated, scattered adakitic volcanism started in western Panama fed by a slab window beneath Costa Rica and the northern part of Panama (Johnston and Thorkelson, 1997; Abratis and Wörner, 2001), leading to the present day situation.

\subsection{OUNTLINE OF THIS STUDY}

This thesis is subdivided into six chapters. Chapter 1 gives a brief introduction to the Rio Chagres project, subduction zone arc magmatism in general and the geological background of this study.

Chapter 2 summarizes the sample collection and sample preparation as well as all analytical methods used.

Chapter 3 describes the hydrothermal alteration processes attributed to high- and low-temperature water/rock interactions in a submarine magmatic setting using the example of Chagres igneous complex and its implications for the isotope and trace element interpretation in the later chapters.

Chapter 4 documents preliminary results about the history of the Panamanian land bridge based on major and trace element data from samples collected from 2002 to 2006 and nine already present Ar-Ar ages. The $\sim 200$ samples from 2006 were processed, analysed and combined with the data of the earlier field trips. Major ideas about timing, spatial distribution and sources of magmatism were developed and changed slightly with time and between chapter 4 and 5, which are based on published papers. Mainly based on trace element patterns and literature data as well as a few initial Ar-Ar ages we defined three different groups of basement rocks of the Caribbean large igneous province and three additional magmatic arc groups of different age and composition. We assumed a developing arc system along the Cordillera de Panama propagating from east to west. The younger arc samples are exposed in isolated centers near the Pacific coast and older samples are found further North up in the Cordillera de Panama (Fig. 1.1A). The distinction between the younger and the older arc rocks has been done by field observation based on petrography of the rocks and morphologic features of the volcanoes due to a lack of age data. 

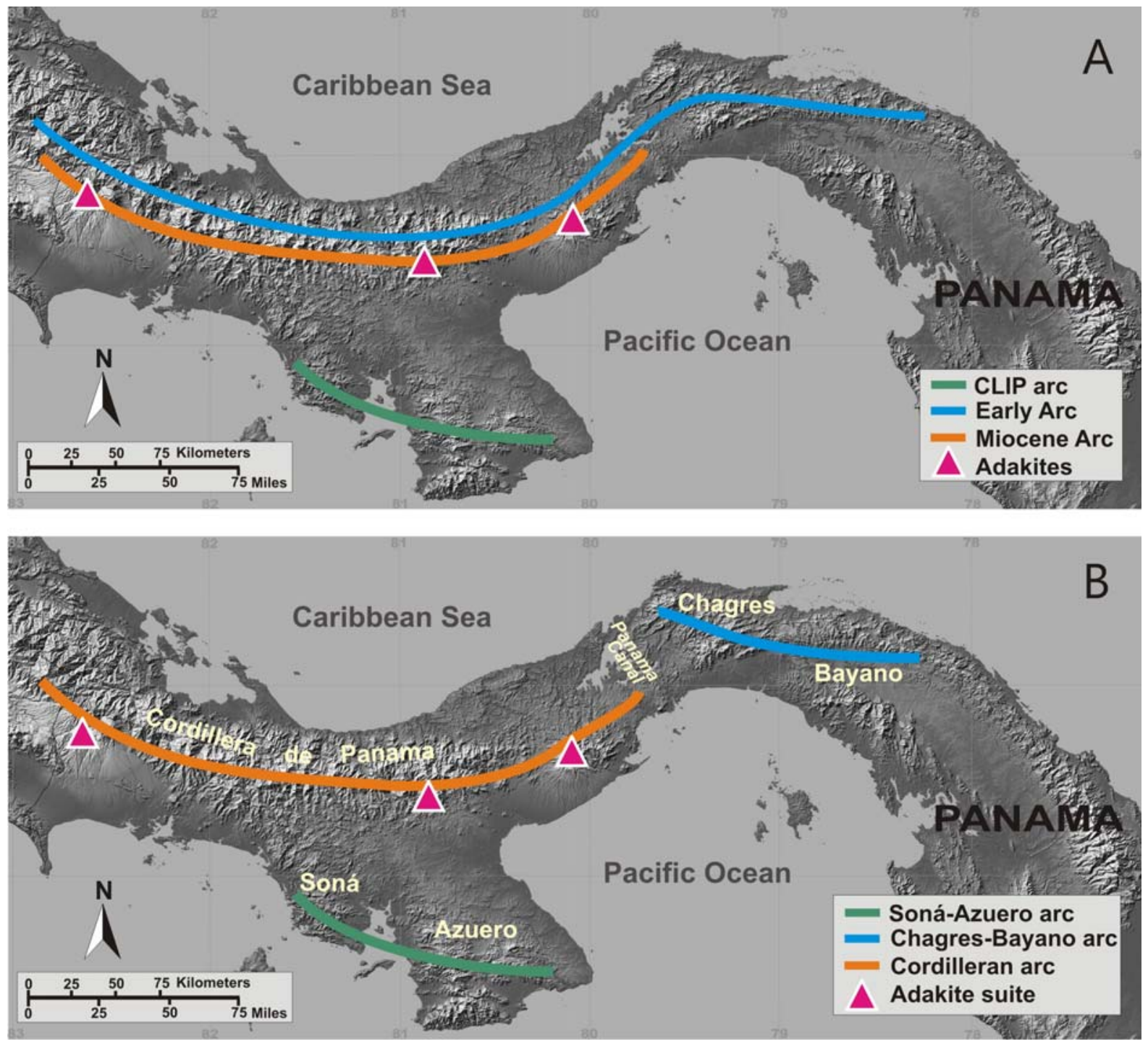

Figure 1.2. DEM (digital elevation model) map of Panama showing the location of the different magmatic arcs, $(A)$ according to chapter 4 and (B) after chapter 5, discussed in this thesis. CLIP-Caribbean large igneous province.

Chapter 5 is build on the previous one and provides detailed insights to magma source compositions, timing and spatial distribution of the different arc phases, initiation of the subduction zone and changes in magma sources trough time related by tectonic rearrangements. These improved findings were possible to draw based on Sr-, Nd-, Pb-, and O-isotope analysis of 40 samples and 26 new Ar-Ar ages. As a consequence we found the location of the older arc from chapter 4 needed to be modified. Based on extended Ar-Ar age data the arc is more localized in the area of Chagres and Bayano region. The Cordillera de Panama west of the Panama Canal is solely composed of younger arc rocks (Fig.1.1B).

Chapter 6 supplies a summary of conclusions from all chapters. 
The electronic Appendix provides a full data table, detailed Ar-Ar results and two additional maps showing the sample regions in detail.

\subsection{REFERENCES}

Abratis, M., and Wörner, G., 2001, Ridge collision, slab-window formation, and the flux of Pacific asthenosphere into the Caribbean realm: Geology, v. 29, no. 2, p. $127-130$.

Barckhausen, U., Ranero, C. R., Cande, S. C., Engels, M., and Weinrebe, W., 2008, Birth of an intraoceanic spreading center: Geology, v. 36, no. 10, p. 767-770.

Brantley, S. R., 1994, Volcanoes of the United States, U.S. Dept. of the Interior, U.S. Geological Survey.

Buchs, D. M., Arculus, R. J., Baumgartner, P. O., Baumgartner-Mora, C., and Ulianov, A., 2010, Late Cretaceous arc development on the SW margin of the Caribbean Plate: Insights from the Golfito, Costa Rica, and Azuero, Panama, complexes: Geochemistry Geophysics Geosystems, v. 11, p. 35.

Carr, M., Feigenson, M., Patino, L., and Walker, J., 2003, Volcanism and geochemistry in Central America; progress and problems, in Eiler, J. M., ed., Inside the Subduction Factory: Geophysical Monograph Series, p. 153-174.

Coates, A. G., Collins, L. S., Aubry, M. P., and Berggren, W. A., 2004, The geology of the Darien, Panama, and the late Miocene-Pliocene collision of the Panama arc with northwestern South America: Geological Society of America Bulletin, v. 116, no. 11-12, p. 1327-1344.

Coates, A., Aubry, M., Berggren, W., and Collins, L., 2000, New evidence for the earliest stages in the rise of the Isthmus of Panama from Bocas del Toro, Panama: Geological Society of America, 2000 annual meeting Abstracts with Program, v. 32 p. A-146.

Coates, A. G., Jackson, J. B. C., Collins, L. S., Cronin, T. M., Dowsett, H. J., Bybell, L. M., Jung, P., and Obando, J. A., 1992, Closure of the Isthmus of Panama: The near-shore marine record of Costa Rica and western Panama: Geological Society of America Bulletin, v. 104, no. 7, p. 814-828.

Collins, L. S., Coates, A. G., Berggren, W. A., Aubry, M.-P., and Zhang, J., 1996, The late Miocene Panama isthmian strait: Geology, v. 24, no. 8, p. 687-690.

de Boer, J., Drummond, M., Bordelon MJ, Defant MJ, Bellon H, and RC, M., 1995, Cenozoic magmatic phases of the Costa Rican island arc (Cordillera de Talamanca), in Mann, P., ed., Geologic and Tectonic Development of the Caribbean Plate Boundary in Southern Central America: Boulder, Colorado, Geological Society of America, p. 35-55.

de Boer, J. Z., Defant, M. J., Stewart, R. H., Restrepo, J. F., Clark, L. F., and Ramirez, A. H., 1988, Quaternary calc-alkaline volcanism in western Panama: Regional variation and implication for the plate tectonic framework: Journal of South American Earth Sciences, v. 1, no. 3, p. 275-293.

Defant, M., Clark, L., Stewart, R., Drummond, M., de Boer, J., Maury, R., Bellon, H., Jackson, T., and Restrepo, J., 1991a, Andesite and dacite genesis via 
contrasting processes: the geology and geochemistry of El Valle Volcano, Panama: Contributions to Mineralogy and Petrology, v. 106, no. 3, p. 309-324.

Defant, M. J., Richerson, P. M., De Boer, J. Z., Stewart, R. H., Maury, R. C., Bellon, H., Drummond, M. S., Feigenson, M. D., and Jackson, T. E., 1991b, Dacite Genesis via both Slab Melting and Differentiation: Petrogenesis of La Yeguada Volcanic Complex, Panama: Journal of Petrology, v. 32, no. 6, p. 1101-1142.

Drummond, M. S., Bordelon, M., de Boer, J. Z., Defant, M. J., Bellon, H., and Feigenson, M. D., 1995, Igneous petrogenesis and tectonic setting of plutonic and volcanic rocks of the Cordillera de Talamanca, Costa Rica-Panama, Central American arc: American Journal of Science, v. 295, no. 7, p. 875-919.

Duque-Caro, H., 1990, The choco block in the northwestern corner of South America: Structural, tectonostratigraphic, and paleogeographic implications: Journal of South American Earth Sciences, v. 3, no. 1, p. 71-84.

Farris, D. W., Jaramillo, C., Bayona, G., Restrepo, S. A., Montes, C., Cardona, A., Mora, A., Speakman, R. J., Glasscock, M. D., and Valencia, V., in press, Fracturing of the Panamanian Isthmus during initial collision with South America: Geology.

Goossens, P. J., Rose, W. I. J., and Flores, D., 1977, Geochemistry of tholeiites of the Basic Igneous Complex of northwestern South America: Geological Society of America Bulletin, v. 88, no. 12, p. 1711-1720.

Harmon, R.S. (ed), 2005, The Rio Chagres, Panama, Multidisciplinary profile of a tropical watershed: Springer, Water Science and Technology Library, v. 52, p.1-355

Hauff, F., Hoernle, K., Schmincke, H. U., and Werner, R., 1997, A Mid Cretaceous origin for the Galápagos hotspot: volcanological, petrological and geochemical evidence from Costa Rican oceanic crustal segments: Geologische Rundschau, v. 86, no. 1, p. 141-155.

Hauff, F., Hoernle, K., van den Bogaard, P., Alvarado, G., and Garbe-Schönberg, D., 2000, Age and geochemistry of basaltic complexes in western Costa Rica: Contributions to the geotectonic evolution of Central America: Geochemistry Geophysics Geosystems, v. 1, no. 5.

Haug, G. H., and Tiedemann, R., 1998, Effect of the formation of the Isthmus of Panama on Atlantic Ocean thermohaline circulation: Nature, v. 393, no. 6686, p. 673-676.

Haug, G. H., Tiedemann, R., Zahn, R., and Ravelo, A. C., 2001, Role of Panama uplift on oceanic freshwater balance: Geology, v. 29, no. 3, p. 207-210.

Hoernle, K., and Hauff, F., 2007, Oceanic Igneous Complexes in Bundschuh, J., and Avarado, G., eds., Central America: Geology, Resources and Hazards: Lisse, Swets \& Zeitlinger, p. 523-547.

Hoernle, K., Hauff, F., and van den Bogaard, P., 2004, 70 m.y. history (139-69 Ma) for the Caribbean large igneous province: Geology, v. 32, no. 8, p. 697-700.

Hoernle, K., van den Bogaard, P., Werner, R., Lissinna, B., Hauff, F., Alvarado, G., and Garbe-Schonberg, D., 2002, Missing history (16-71 Ma) of the Galápagos hotspot: Implications for the tectonic and biological evolution of the Americas: Geology, v. 30, no. 9, p. 795-798. 
Johnston, S. T., and Thorkelson, D. J., 1997, Cocos-Nazca slab window beneath Central America: Earth and Planetary Science Letters, v. 146, no. 3-4, p. 465474.

Lonsdale, P., and Klitgord, K. D., 1978, Structure and tectonic history of the eastern Panama Basin: Geological Society of America Bulletin, v. 89, no. 7, p. 981999.

Mann, P., and Kolarsky, R., 1995, East Panama deformed belt; structure, age, and neotectonic significance in Mann, P., ed., Geologic and Tectonic Development of the Caribbean Plate Boundary in Southern Central America: Boulder, Colorado, Geological Society of America, p. 111-130.

Mann, P., Rogers, R. D., and Gahagan, L., 2007, Overview of plate tectonic history and its unresolved tectonic problems, in Bundschuh, J., and Alvarado, G. E., eds., Central America: Geology, Resources and Hazards: London, Taylor and Frencis, p. 205-241.

Maury, R. C., Defant, M. J., Bellon, H., de Boer, J. Z., Stewart, R. H., C., , and Joseph, 1995, Early Tertiary arc volcanics from eastern Panama, in Mann, P., ed., Geologic and Tectonic Development of the Caribbean Plate Boundary in Southern Central America: Boulder, Colorado, Geological Society of America, p. 29-34.

Pindell, J., Kennan, L., Stanek, K. P., Maresch, M. W., Draper G., 2006, Foundations of Gulf of Mexico and Caribbean evolution: eight controversies resolved: Geological Acta, v. 4, p. 303-341. 


$$
\text { Cingerier } 2
$$

Sample collection and analytical methods 


\subsection{SAMPLE COLLECTION}

Figure 2.1 shows the locations of the analysed samples. The study area extends along the Central Cordillera of Panama from the Lake Bayano region in the east at $9^{\circ} 11^{\prime} 54^{\prime \prime} \mathrm{N}, 78^{\circ} 23^{\prime} 13^{\prime \prime} \mathrm{W}$ to the Costa Rican border in the west at $8^{\circ} 41^{\prime} 43^{\prime \prime} \mathrm{N}$, $82^{\circ} 48^{\prime} 40^{\prime \prime} \mathrm{W}$. Samples were also collected in a NW-SE traverse along the Panama Canal, throughout the Upper Rio Chagres region northeast of the Panama Canal, and from the Azuero and Soná peninsulas in southern Panama. Most of the samples are volcanic and plutonic rocks of Upper Cretaceous to Quaternary age, but there are also some samples from the Cretaceous basement included.

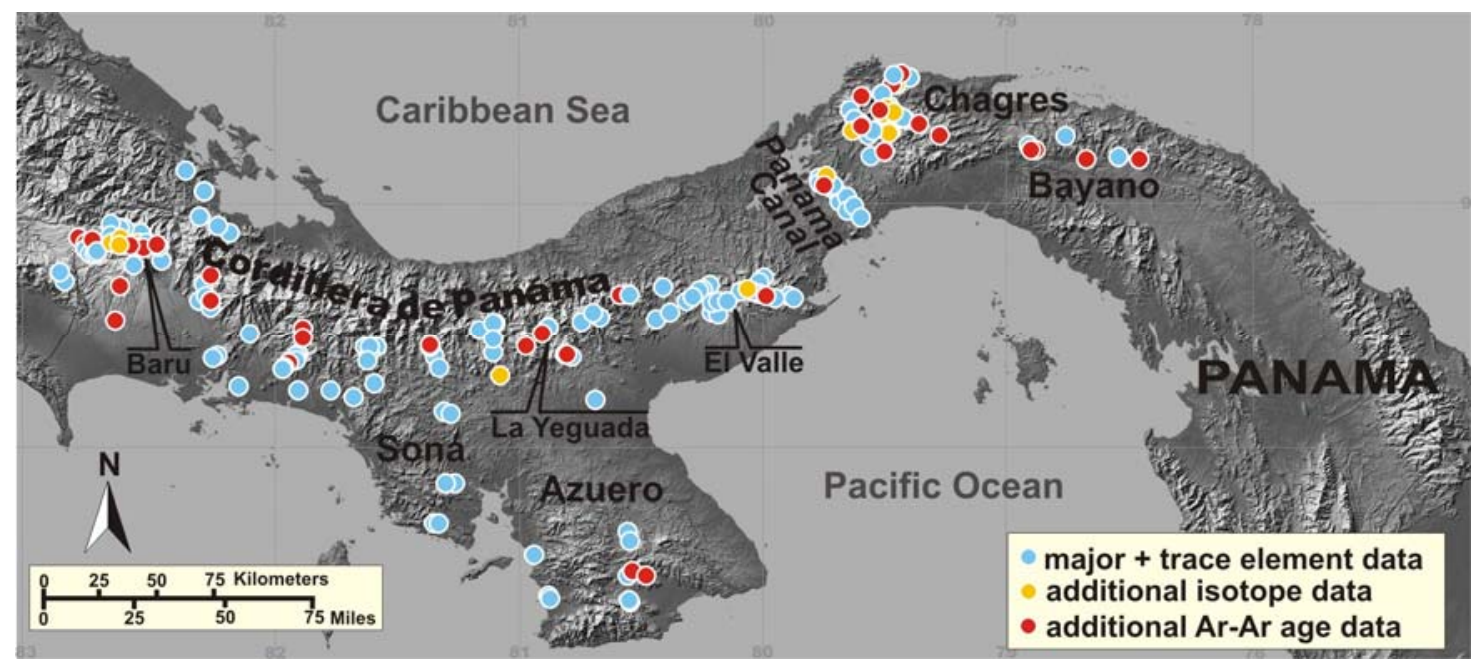

Figure 2.1. DEM (digital elevation model) map of Panama showing the geographic distribution of the samples analysed for this study. Grey symbols represent sample locations from which we obtained major and trace element data. Yellow symbols define samples with additional isotope data and the red symbols display samples with Ar-Ar dates available.

A set of 438 samples of the least altered rocks were selected from a larger suite of samples collected from central-western Panama over an E-W distance of about 500 $\mathrm{km}$ from the Lake Bayano area in the east to the Costa Rica border in the west (Fig. 2.1) between 2001 and 2006 in six individual field sessions. Only the freshest rocks were sampled in the field, but due to the tropical environment and the alteration history of these rocks some samples exhibited minor but noticeable degrees of chemical alteration. The samples were cleaned from alteration rimes, where present, in the field and the rocks were chipped to pieces (ca. $\leq 5 \mathrm{~cm}$ ). Depending on the rock type (grain size), between 1-3 kg of sample was collected for subsequent laboratory analysis. 


\subsection{ANALYTICAL APPROACH}

After preliminary examination and description based on hand specimen and thin sections, 310 samples were selected for geochemical analysis at the Geosciences Center at the University of Göttingen by X-ray fluorescence spectroscopy (XRF) and Inductive Coupled Plasma Mass Spectrometry (ICP-MS).

Based on theses results as well as on mineral content, lithology, and presumed age from geological field relations, subsets of 40 samples (mainly separated minerals) were selected for age dating and determination of ${ }^{87} \mathrm{Sr} /{ }^{86} \mathrm{Sr},{ }^{143} \mathrm{Nd} /{ }^{144} \mathrm{Nd}$ as well as ${ }^{206} \mathrm{~Pb} /{ }^{204} \mathrm{~Pb},{ }^{207} \mathrm{~Pb} /{ }^{204} \mathrm{~Pb},{ }^{208} \mathrm{~Pb} /{ }^{204} \mathrm{~Pb}$ and ${ }^{18} \mathrm{O} /{ }^{16} \mathrm{O}$ isotope ratios. The samples were chosen to represent all lithologies and age groups as well as a large spatial distribution. These samples are chosen to characterise the different arc systems along the Isthmus of Panama trough time. Amphiboles and K-feldspars were preferred to pyroxenes and other mineral phases for analysis because these minerals have elevated REE, $\mathrm{K}$ and/or $\mathrm{Sr}$ contents which is important for isotopic analysis and for $\mathrm{Ar}-\mathrm{Ar}$ age dating. These 40 samples were dated by the ${ }^{40} \mathrm{Ar} /{ }^{39} \mathrm{Ar}$ method at the UW-Madison Rare Gas Geochronology Laboratory and for 35 samples Ar-Ar reliable ages were received. As a consequence of strong secondary alteration of the Soná-Azuero arc rocks, only two samples from his group were suitable for isotopic analysis. The Chagres-Bayano arc and Adakite suite groups each contributed 14 samples and 10 samples from the Cordilleran arc group were analyzed for isotopes and age.

In a different approach another subset of 13 samples of the Chagres igneous complex were measured in terms of alteration effects produced by hydrothermal fluid circulation during or shortly after emplacement of these rocks. Polished thin sections were used for phase characterization via optical polarization microscopy, electron micro probe (EMP) and Raman spectroscopy. Mineral separates of amphibole, clinopyroxene and feldspar as well as whole rock powder were analyzed for ${ }^{18} \mathrm{O} /{ }^{16} \mathrm{O}$ isotope ratios. Whole rock powders were used for loss on ignition determination.

\subsubsection{Sample Preparation}

After sorting and cleaning, the rock fragments were first broken into small chips in a jaw crusher and then further reduced in size in a roller mill. Approximately $100 \mathrm{~g}$ of the crushed sample material was separated by a rotary sample divider and then ground to powder $(<65 \mu \mathrm{m})$ in an agate ball mill for X-ray fluorescence spectroscopy 
(XRF) and Inductive Coupled Plasma Mass Spectrometry (ICP-MS) as well as for whole rock ${ }^{18} \mathrm{O} /{ }^{16} \mathrm{O}$ isotope ratios.

The crushed material was further used for mineral separation. These samples were sieved wet and then the 500-250 $\mu \mathrm{m}$ fraction was processed repeatedly in a magnetic separator to concentrate specific mineral phases of interest (amphibole, pyroxene, and feldspar). For ${ }^{40} \mathrm{Ar} /{ }^{39} \mathrm{Ar}$ dating and isotopic analysis, separation of amphibole from the other mineral phases proved challenging. Intergrowth and inclusions necessitated the time-consuming procedure of hand picking under a binocular microscope.

Polished high quality thin sections were made for those samples which were analysed for fluid alteration processes by electron micro probe (EMP) and Raman spectroscopy.

\subsubsection{X-ray Fluorescence Spectroscopy (XRF)}

Concentrations of major and minor elements ( $\mathrm{Si}, \mathrm{Ti}, \mathrm{Al}, \mathrm{Fe}, \mathrm{Mn}, \mathrm{Mg}, \mathrm{Ca}, \mathrm{Na}, \mathrm{K}, \mathrm{P}$ ) as well as selected trace elements ( $\mathrm{Nb}, \mathrm{Zr}, \mathrm{Y}, \mathrm{Sr}, \mathrm{Rb}, \mathrm{Ga}, \mathrm{Zn}, \mathrm{Cu}, \mathrm{Ni}, \mathrm{Co}, \mathrm{Cr}, \mathrm{V}, \mathrm{Ba}, \mathrm{Sc}$ ) were analysed by $\mathrm{X}$-ray fluorescence spectroscopy (XRF). Samples were prepared for measurement as glass disks. The fully automated fusion instrument, SGE 21 from Schoeps was used. The glass disks, used for both major and trace element determination, were prepared by mixing lithium tetraborate and lithium metaborate (Spectromelt A 12, Merck) with the sample powder. $4200 \mathrm{mg}$ of this flux and $700 \mathrm{mg}$ of the sample are weighed in platinum-gold crucibles and fused for $15 \mathrm{~min}$ at $1100{ }^{\circ} \mathrm{C}$, after which the melt is poured into pre-heated, polished $32 \mathrm{~mm}$-diameter platinum molds. Measurements were performed using a PANalytical AXIOS Advanced sequential X-ray fluorescence spectrometer. For the calibration of major and trace element determination, about 50 reference materials from the US Geological Survey, the International Working Group "Analytical Standards of Minerals, Ores and Rocks", the National Research Council of Canada, the Geological Survey of Japan, the South African Bureau of Standards, and the U.S. National Institute of Standards \& Technology were used. For major element analyses, the analytical precision is better than $1-2 \%$; for trace element determinations standard deviations of consecutive analyses are in the range of 2 to $5 \%$ relative at the level of 20 to $30 \mathrm{ppm}$. Detection limits vary from 3 to $0.5 \mathrm{ppm}$ for the majority of the measured elements (G. Hartmann, personal communication). 


\subsubsection{Inductive Coupled Plasma Mass Spectrometry (ICP-MS)}

Inductive Coupled Plasma Mass Spectrometry (ICP-MS) can simultaneously analyze a wide spectrum of trace elements from $\mathrm{Li}$ to $U$ at low detection limits and high analytical precision, especially for those elements with masses $>80$. A general description of the method is given in Potts (1987). Rare Earth Elements (La-Lu), High Field Strength Elements ( $\mathrm{Nb}, \mathrm{Ta}, \mathrm{Zr}$, Hf), Large Ion Lithophile Elements (Rb, Sr, Ba, $\mathrm{Cs}$ ) and a group of other trace elements ( $\mathrm{Li}, \mathrm{Sc}, \mathrm{Cu}, \mathrm{V}, \mathrm{Cr}, \mathrm{Co}, \mathrm{Ni}, \mathrm{Zn}, \mathrm{Y}, \mathrm{Pb}, \mathrm{Th}, \mathrm{U}$ ), were measured using a Perkin Elmer SCIEX ELAN DRC II inductive coupled plasma mass spectrometer. Sample solutions were prepared following an approach modified from Heinrichs \& Herrmann (1990). First, $100 \mathrm{mg}$ of sample powder $(<65 \mu \mathrm{m})$ was dissolved in $1 \mathrm{ml} \mathrm{HF}$ and $2 \mathrm{ml} \mathrm{HNO} 3$ by pressure digestion $\left(180{ }^{\circ} \mathrm{C} / 8 \mathrm{~h}\right.$ ). The solutions were evaporated to dryness for 1 hour at $140^{\circ} \mathrm{C}$. For the second pressure digestion for 8 hours at $180^{\circ} \mathrm{C}$, the samples were subsequently dissolved in $1 \mathrm{ml} \mathrm{HF}$ and $1 \mathrm{ml} \mathrm{HClO}_{4}$. The solutions were evaporated and different quantities of $\mathrm{HClO}_{4}$ and $\mathrm{HCl}$ were added in succession and evaporated. After this procedure, $2 \mathrm{ml} \mathrm{HNO}_{3}$ and $10 \mathrm{ml}$ de-ionised water, together with $200 \mu \mathrm{l}$ of an internal standard containing $\mathrm{Ge}$, $\mathrm{Rh}, \mathrm{In}$, and $\mathrm{Re}$, was added to the sample. This solution was transferred into a $100 \mathrm{ml}$ quartz-glass flask and the remaining volume was filled with de-ionised water. The resulting solution contained the sample in a dilution 1:1000 with $20 \mathrm{ppb} \mathrm{Ge}, \mathrm{Rh}, \mathrm{Re}$, and In as internal standards. Based on co-processing the laboratory internal standards and the international standards JB-3 and JA-2 as unknown samples, the $2 \sigma$ error of the analytical method was estimated to be $<20 \%$ for $\mathrm{Nb}$ and $\mathrm{Ta},<10 \%$ for $\mathrm{Be}, \mathrm{Cs}, \mathrm{Cu}, \mathrm{Hf}, \mathrm{Li}, \mathrm{Y}, \mathrm{Rb}, \mathrm{Pb}, \mathrm{Tl}$, Th and $\mathrm{U}$ and ca. $5 \%$ for the REE.

\subsubsection{Thermal lonization Mass Spectrometry (TIMS)}

Isotope ratios of ${ }^{87} \mathrm{Sr} /{ }^{86} \mathrm{Sr},{ }^{143} \mathrm{Nd} /{ }^{144} \mathrm{Nd},{ }^{206} \mathrm{~Pb} /{ }^{204} \mathrm{~Pb},{ }^{207} \mathrm{~Pb} /{ }^{204} \mathrm{~Pb}$, and ${ }^{208} \mathrm{~Pb} /{ }^{204} \mathrm{~Pb}$ were measured using a Thermo Finnigan TRITON TI thermal ionization mass spectrometer (TIMS). For Sr-, Nd-, and $\mathrm{Pb}$-isotope ratio determinations, $30 \mathrm{mg}$ of hand-picked feldspar and $50 \mathrm{mg}$ of amphibole were leached with $1 \mathrm{ml} 0.18 \mathrm{~N} \mathrm{HCl}$ at $50{ }^{\circ} \mathrm{C}$ and $100{ }^{\circ} \mathrm{C}$ each for $15 \mathrm{~min}$. After repeated rinsing and drying the mineral separates for $\mathrm{Sr}$ and $\mathrm{Nd}$ were dissolved in $4 \mathrm{ml} \mathrm{HF}: \mathrm{HNO}_{3}$ (1:1) for 24 hours at 200 ${ }^{\circ} \mathrm{C}$ in Savillex beakers within a pressure vessel. The solution was evaporated at 140 ${ }^{\circ} \mathrm{C}$ to complete dryness and subsequently dissolved in $4 \mathrm{ml} 6 \mathrm{~N} \mathrm{HCl}$ and again evaporated to dryness. Finally the samples were dissolved in $2.5 \mathrm{ml} 2.6 \mathrm{~N} \mathrm{HCl}$, 
transferred in PE vials and centrifuged. During the separation procedure the sample solution was rinsed with $2.6 \mathrm{~N} \mathrm{HCl}$ through columns containing ion exchange resin BIORAD AG 50W-X8, 200-400 mesh. The Sr-rich elution was collected and evaporated to dryness and stored until measured. For Nd separation, the REE-rich fraction of the first separation step was separated in a second set of columns. $\mathrm{Nd}$ was rinsed with $0.18 \mathrm{~N} \mathrm{HCL}$ through columns filled with Teflon powder impregnated with ion-exchanging HDEHP Bis-(2-etylhexy)-Phosphate. For TIMS measurements, the separated $\mathrm{Sr}$ and $\mathrm{Nd}$ was dissolved in $3 \mu \mathrm{l} \mathrm{HNO}_{3}$ and $3 \mu \mathrm{I} \mathrm{H}_{3} \mathrm{PO}_{4}$. Both fractions were loaded on Re-double filaments $(\sim 1 \mu \mathrm{g})$. The measured $\mathrm{Sr}$ - and $\mathrm{Nd}$-isotope ratios were corrected for mass fractionation to ${ }^{86} \mathrm{Sr} /{ }^{88} \mathrm{Sr}=0.1194$ and ${ }^{146} \mathrm{Nd} /{ }^{144} \mathrm{Nd}=$ 0.7219 and then normalized to values for NIST SRM-987 (0.710245), and La Jolla (0.511847), respectively. Measured values of these standards over the period of the study were $0.710258 \pm 0.000007$ (10 analyses) and $0.511848 \pm 0.000005$ (10 analysis). External $2 \sigma$ errors are estimated at $<0.001 \%$ for $\mathrm{Sr}$ and $\mathrm{Nd}$.

For $\mathrm{Pb}$ separation about $100 \mathrm{mg}$ of leached minerals were dissolved in $4 \mathrm{ml} \mathrm{HF}$ : $\mathrm{HNO}_{3}(1: 1)$ in Savilex pressure vessels at $200^{\circ} \mathrm{C}$ for at least 12 hours. After pressure digestion and evaporation, the samples were dissolved $2 \mathrm{x}$ in $1 \mathrm{ml} 0.5 \mathrm{~N} \mathrm{HBr}$ and evaporated. For centrifugation, the samples were dissolved in $1 \mathrm{ml} 0.5 \mathrm{~N} \mathrm{HBr}$. $\mathrm{Pb}$ was separated on anion exchange columns containing resin (Biorad AG1-X8, 200400 mesh). The samples were first washed with $1 \mathrm{ml} 0.5 \mathrm{~N} \mathrm{HBr}$ then with $0.3 \mathrm{ml} 2 \mathrm{~N}$ $\mathrm{HCl}$ and finally eluted with $1.5 \mathrm{ml} 6 \mathrm{~N} \mathrm{HCl}$. Alkalis and earth alkalis, were removed by a repeated separation process. The $\mathrm{Pb}$ fraction was mounted on $\mathrm{Re}$ single filament using $3 \mu \mathrm{l} \mathrm{HNO}_{3}$ and $3 \mu \mathrm{l}$ silica-gel. Ionization temperature for $\mathrm{Pb}$ measurement was held \pm constant between $1150{ }^{\circ} \mathrm{C}-1300^{\circ} \mathrm{C}$ and controlled by an optical temperaturereader. Measured $\mathrm{Pb}$-isotope ratios were corrected to NIST SRM-981 using a mass fractionation factor of $0.069 \%$ for ${ }^{206} \mathrm{~Pb} /{ }^{204} \mathrm{~Pb}, 0.077 \%$ for ${ }^{207} \mathrm{~Pb} /{ }^{204} \mathrm{~Pb}$ and $0.049 \%$ for ${ }^{208} \mathrm{~Pb} /{ }^{204} \mathrm{~Pb}$. Thirteen standard measurements gave means of ${ }^{206} \mathrm{~Pb} /{ }^{204} \mathrm{~Pb}=16.92$ $\pm 0.01,{ }^{207} \mathrm{~Pb} /{ }^{204} \mathrm{~Pb}=15.47 \pm 0.01,{ }^{208} \mathrm{~Pb} /{ }^{204} \mathrm{~Pb}=36.73 \pm 0.03$. The total error $(2 \sigma)$ was $<0.1 \%$.

\subsubsection{Dual inlet Gas-source Mass Spectrometry}

Stable isotope ratio mass spectrometry was used to determine the ${ }^{18} \mathrm{O} /{ }^{16} \mathrm{O}$ ratios of single or a few amphibole, pyroxene, and feldspar grains. Measurements were carried out at a Thermo MAT 253 dual inlet gas-source mass spectrometer. The gas 
extraction line used is similar to that described by Sharp (1990) except that $F_{2}$ is used for fluorination instead of $\mathrm{BrF}_{5}$ and that $\mathrm{O}_{2}$ is measured directly and not reacted to $\mathrm{CO}_{2}$. For a measurement, $\sim 1 \mathrm{mg}$ of minerals, which typically comprised 1 to 3 crystals at a grain size of 500-250 $\mu \mathrm{m}$, were used. For each batch of analyses, 12 samples and 4 standards were loaded into a Ni sample holder and evacuated over night. The samples were heated $\left(>2000{ }^{\circ} \mathrm{C}\right)$ by a $\mathrm{CO}_{2}$-laser in an atmosphere of $\mathrm{F}_{2}$, liberating molecular oxygen and forming residual fluorides. Excess $F_{2}$ is then removed by reaction with $\mathrm{NaCl}$ at $\sim 150{ }^{\circ} \mathrm{C}$ to form $\mathrm{NaF}$ and any $\mathrm{Cl}_{2}$ produced is collected in two liquid nitrogen traps at $-196{ }^{\circ} \mathrm{C}$. Finally, purified sample $\mathrm{O}_{2}$ is trapped on a molecular sieve at $-196{ }^{\circ} \mathrm{C}$ and then the $\mathrm{O}_{2}$ is expanded into the mass spectrometer inlet system for a simultaneous analysis of masses 32,33 , and 34 by heating of the molecular sieve to $\sim 80{ }^{\circ} \mathrm{C}$. The sample gas is compared with a reference $\mathrm{O}_{2}$ of known $\delta^{18} \mathrm{O}_{\text {Vsmow }}$ (Vienna Standard Mean Ocean Water) of $+12.5 \%$ to determine its O-isotope ratios. For further details see Pack et al. (2007). Measured $\delta^{18} \mathrm{O}$ values were corrected for machine drift by normalization to measured standards (NBS 28 quartz, San Carlos olivine, UWG-2 garnet).

\subsection{6 ${ }^{40} \mathrm{Arl}{ }^{39} \mathrm{Ar}$ Age Determination}

${ }^{40} \mathrm{Ar} /{ }^{39} \mathrm{Ar}$ incremental heating experiments were performed on amphibole, K-feldspar, plagioclase crystals, and matrix material in the Rare Gas Geochronology Laboratory at the University of Wisconsin-Madison using a defocused $25 \mathrm{~W} \mathrm{CO}_{2}$ laser. Individual grains were analyzed from four samples, but in most cases, multi crystal aliquots ( $10 \mathrm{mg}$ ) were lased to yield sufficient argon for analysis. Prior to each laser stepheating experiment, samples were pre-degassed at $2.0 \%$ power to remove water and atmospheric argon. Experiments yielded largely concordant age spectra with 410 steps comprising $>82 \%$ of the gas released. Isotopic analyses and data reduction followed the procedures of Smith et al. (2006).

\subsubsection{Electron Micro Probe (EMP)}

The electron micro probe JEOL JXA 8900 RL was used for backscattered electron images (BSE) and quantitative wavelength dispersive (WDX) measurements to determine the different secondary mineral phases which formed during hydrothermal alteration to quantify the element values in specific minerals to find differences between unaltered and altered species and fluids, to give ideas about element 
mobility. Measurements were carried out on polished thin sections coated with carbon to ensure conductivity. BSE images were taken in the composition (COMPO) mode at $15 \mathrm{kV}$ accelerating voltage and $15 \mathrm{nA}$ beam current in a slow scanning mode to increase resolution. WDX measurements were carried out at the same beam conditions with a beam diameter of $5 \mu \mathrm{m}$ for the sample and $20 \mu \mathrm{m}$ for the standards. The oxides $\mathrm{SiO}_{2}, \mathrm{Al}_{2} \mathrm{O}_{3}, \mathrm{TiO}_{2}, \mathrm{FeO}, \mathrm{MgO}, \mathrm{MnO}, \mathrm{CaO}, \mathrm{Cr}_{2} \mathrm{O}_{3}, \mathrm{Na}_{2} \mathrm{O}, \mathrm{K}_{2} \mathrm{O}$ and $\mathrm{BaO}$ were quantified on a 24 oxygen basis in the main silicate minerals like feldspar, amphibole, pyroxene and dark mica with a general silica program. The counting times on the peak were $15 \mathrm{~s}$ for all elements except for $\mathrm{Ba}(30 \mathrm{~s})$. The background on both sides of the peak was counted each $5 \mathrm{~s}$ except for $\mathrm{Ba}$ (15 s). The results were corrected with the phi-rho-z method. The detection limits for the different elements were between 100 ppm for $\mathrm{K}$ and around 300 ppm for $\mathrm{Ba}$.

\subsubsection{Raman spectroscopy}

Raman spectroscopy was used in addition to the electron micro probe for secondary mineral phases identification. A Horiba Jobin Yvon LabRam-HR 800 UV microRaman spectrometer with a focal length of $800 \mathrm{~mm}$ was used. The samples were excited with a wavelength line of $488 \mathrm{~nm}$ of an Argon lon Laser (Melles Griot IMA $106020 B 0 S$ ) with a laser power of $20 \mathrm{~mW}$. The laser beam was dispersed by a 600 I/mm grating on a CCD detector with $1024 \times 256$ pixels, yielding a spectral dispersion of $0.43 \mathrm{~cm}^{-1}$. The acquisition time was $15 \mathrm{~s}$ for a spectral range of $100-2000 \mathrm{~cm}^{-1}$. For calibration of the spectrometer a silicon standard with a major peak at $520.4 \mathrm{~cm}^{-1}$ was

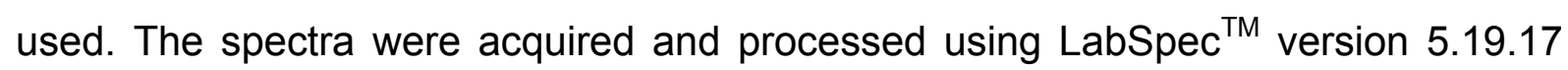
(Jobin-Yvon, Villeneuve d'Ascq, France).

\subsubsection{Loss on Ignition (LOI) Determination}

To measure the water content in the different samples the loss on ignition was determined. For this purpose $5 \mathrm{~g}$ of whole rock powder $(<65 \mu \mathrm{m})$ was weighted in and heated over a temperature ramp to $1050{ }^{\circ} \mathrm{C}$ for $24 \mathrm{~h}$. The powder was weighted afterwards and the water content was calculated following the equation:

$\frac{L O I(g) \times 100}{\text { initial weight }(g)}=\% \mathrm{H}_{2} \mathrm{O}$ 


\subsection{REFERENCES}

Heinrichs, H., and Herrmann, A. G., 1990, Praktikum der analytischen Geochemie, Springer-Lehrbuch: Berlin, Springer-Verlag, 669p.

Pack, A., Toulouse, C., and Przybilla, R., 2007, Determination of oxygen triple isotope ratios of silicates without cryogenic separation of NF3-technique with application to analyzes of technical $\mathrm{O}_{2}$ gas and meteorite classification: Rapid Communications in Mass Spectrometry, v. 21, p. 3721-3728.

Potts, P. J., 1987, A handbook of silicate rock analysis, Analytica Chimica Acta: London, Blackie, $622 \mathrm{p}$.

Sharp, Z. D., 1990, A laser-based microanalytical method for the in situ determination of oxygen isotope ratios of silicates and oxides: Geochimica et Cosmochimica Acta, v. 54, no. 5, p. 1353-1357.

Smith, M. E., Singer, B. S., Carroll, A. R., and Fournelle, J. H., 2006, High-resolution calibration of Eocene strata: ${ }^{40} \mathrm{Ar} /{ }^{39} \mathrm{Ar}$ geochronology of biotite in the Green River Formation: Geology, v. 34, p. 393-396. 


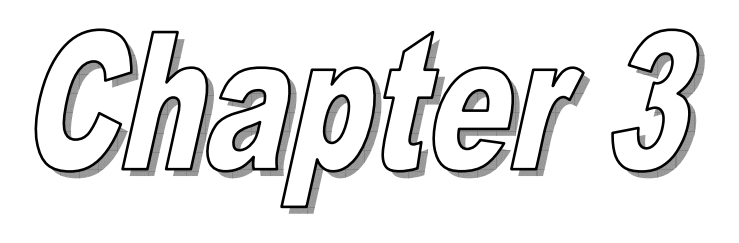

Sub-seafloor alteration of the Chagres igneous complex, central Panama and its implication for O-isotopes and major and trace elements 


\subsection{ABSTRACT}

The $\delta^{18} \mathrm{O}$ values of 13 whole rock samples and their major phenocrysts (amphibole, pyroxene and plagioclase) from magmatic rocks from the Chagres igneous complex (CHICO) were measured in order to asses alteration processes on submarine arc lavas.

The values range for $\delta^{18} \mathrm{O}_{\text {amph }}$ from $0.8-6.1 \%$, for $\delta^{18} \mathrm{O}_{\text {plag }}$ from $4.8-10.2 \%$ and for $\delta^{18} \mathrm{O}_{\mathrm{WR}}$ from 4.2-9.5\%. Based on these values three types of alteration were defined. Type 1 represents samples which are affected by low temperature hydrothermal alteration. Type $2+3$ comprise samples that experienced a subsequent second low temperature alteration with a low water-rock ratio (2) and high water-rock ratio (3).

The mobility of major and trace elements does not systematically correlate to alteration types. Geochemical variations in magma source composition, additional slab fluids and one or rather two types of alteration can not be resolved.

$\delta^{18} O_{W R}$ values for most altered samples show that the over all enrichment or depletion in $\delta^{18} \mathrm{O}$ is less than $1 \%$. Based on the $\delta^{18} \mathrm{O}_{\mathrm{WR}}$ data the degree of alteration of the $\mathrm{CHICO}$ is minor compared to mid ocean ridges and oceanic seamounts where high-T alteration is often expressed more strongly. This lower degree of alteration shows only little influence on isotope systematics and element patterns which leads to a good interpretability in relation to source compositions based on correct isotopes and trace elements.

\subsection{INTRODUCTION}

\subsubsection{The Chagres Igneous Complex}

Sub-seafloor exchanges between igneous rocks and fluids are very diverse and vary from cold water to hot hydrothermal solutions and from low to high water-rock ratios. These processes are well studied for the upper oceanic crust at spreading ridges and ophiolite complexes (e.g. Alt et al., 1996; Bach et al., 2001; Bednarz and Schmincke, 1989) as well as oceanic seamounts (Schiffman and Staudigel, 1994, 1995).

The Chagres igneous complex ( $\mathrm{CHICO}$ ) in central Panama is a $66 \mathrm{Ma}$ old submarine volcanic arc complex (Wörner et al, 2009).It formed in response to the subduction of the Farallon plate beneath the Caribbean plate. The CHICO area was magmatically active in two major pulses over a long time (66-42 Ma). This provides time and heat to develop different fluid circulation systems which lead to multiple alteration events. Today the $\mathrm{CHICO}$ is exposed to the deeper parts of the intrusion level as part of the 
Central American land bridge in Panama. A large variety of different magmatic rock types are exposed in one volcanic complex. The spectrum comprises gabbro to granite intrusive and basalt to dacite volcanic rocks. The $\mathrm{CHICO}$ is mainly build by different submarine volcanic lithologies which are composed of pillow lava, rare pillow breccias and submarine debris flows, but most abundantly massive submarine sheet flows, dykes and dyke swarms. Some of the debris flows contain oxidized clasts which indicate a subaerial eruption. The deeper level consists of massive granite, tonalite, granodiorite, diorite and gabbro intrusions. Several of these intrusions are cut by dykes of different but mainly basaltic composition. These lithologies show that the $\mathrm{CHICO}$ is mainly a submarine volcanic complex with high magma eruption rates with only a small eruptive part above sea level. Thus the $\mathrm{CHICO}$ gives an excellent base to investigate various fluid/rock interactions in a submarine volcanic complex. In this work we present petrological, isotopic and geochemical data on 13 samples from 26 mineral separates and 13 whole rock powders to verify alteration processes in the $\mathrm{CHICO}$. The results provide ideas about element mobility as well as petrological, mineralogical and isotopic changes in microscopic and macroscopic scale, caused by various hydrothermal alterations of a submarine volcanic complex.

\subsubsection{Geological Background}

The plate tectonic history of this region (Pindell et al. 2006) is characterized by intra oceanic triple plate interactions and numerous overlapping tectonic events since Cretaceous. Here only a very brief overview is given. The formation of the rocks that comprise the Central American land bridge started ca. 139-110 Ma (Hoernle et al., 2004) ago in the region of the today's Galápagos hot spot with mafic volcanism forming the Caribbean large igneous province (CLIP). This young oceanic plateau moved on top of the Farallon plate eastward and reached its position of the present Caribbean Plate between South America and the Chortis Block, a geological province of continental affinity, in the Campanian. The CLIP forms the basement for subduction associated arc magmatism which started $71 \mathrm{Ma}$ in the region of the Azuero and Soná peninsula (Wegner et al. 2011). The magmatic arc then continued and formed the $\mathrm{CHICO} 66 \mathrm{Ma}$ ago as part of the new submarine chain of arc volcanoes which was later moved in the today's Chagres-Bayano area. This kind of early arc volcanism continued in the Chagres-Bayano area for $25 \mathrm{Ma}$. Then a period of volcanic lull followed. A new, less depleted type of arc magmatism commenced to 
the west of the older arc along the Cordillera de Panama (de Boer et al., 1995) and lasted from 22 to $7 \mathrm{Ma}$. During the time of arc magmatism (69-16 Ma) seamount terrains with Galápagos affinity such as Quepos, Osa, Burica, Soná and Azuero accreted to the active margin (Hauff et al., 1997, 2000; Hoernle et al., 2002; Buchs et al., 2010). These terrains today are important parts of the basement of this region. Arc magmatism stopped in the Upper Miocene and is followed by a magmatic gap in the region of Western Panama for 2-3 Ma. In the same time interval the cessation of ocean floor spreading in the Panama Basin took place (Lonsdale and Kiltgord, 1978) and the isthmus closed between 6.2 and 3.5 Ma (Coates et al., 1992; Collins et al., 1996). These tectonic events are accompanied by further tectonic rearrangements. Thrust movement in the northern and eastern Panama deformed belt and the Panama fracture zone (Mann and Kolarsky, 1995) took up the plate convergence due to choked subduction which lead to the magmatic gap.

There is only little evidence for active subduction and no sign for "normal" arc volcanism in Panama today (de Boer et al., 1991). However there is isolated, rare Adakite volcanism in western Panama since the last 2 Ma (Defant et al., 1991a; 1991b; Johnston and Thorkelson, 1997; Abratis and Wörner, 2001; Wegner et al., 2011).

\subsection{SAMPLES AND METHODS}

13 samples from the Chagres igneous complex (CHICO) from 13 localities in the Chagres basin (Fig. 3.1) were selected out of 76 samples which were previously analyzed for major and trace elements (Wegner et al., 2011). Samples were chosen to cover a large spatial distribution throughout the complex, different rock types representing the entire spectrum of $\mathrm{SiO}_{2}$ and comprise plutons as well as volcanic rocks. Representative samples of between 1 and $3 \mathrm{~kg}$ were selected for XRF and ICP-MS analysis of whole-rock chemical composition. For further details of sample processing see Wegner et al. (2011).

The $\delta^{18} \mathrm{O}$ values of mineral separates (amphibole, pyroxene and feldspar) and the whole rock powders were determined using a Thermo MAT 253 dual inlet gas-source mass spectrometer. For a measurement, $\sim 1 \mathrm{mg}$ of rock powder and minerals, which typically comprised 1 to 3 crystals at a grain size of $500-250 \mu \mathrm{m}$, were heated $\left(>2000^{\circ} \mathrm{C}\right.$ ) by a $\mathrm{CO}_{2}$-laser in an atmosphere of $\mathrm{F}_{2}$ to release the oxygen. The sample gas is compared with a reference $\mathrm{O}_{2}$ of known $\delta^{18} \mathrm{O}_{\text {vsmow }}$ (Vienna Standard Mean 
Ocean Water) of $+12.5 \%$ to determine its $\delta^{18} \mathrm{O}$-isotope ratios. The measured $\delta^{18} \mathrm{O}$ values were corrected for machine drift by normalization to co-processed NBS 28 quartz standard.

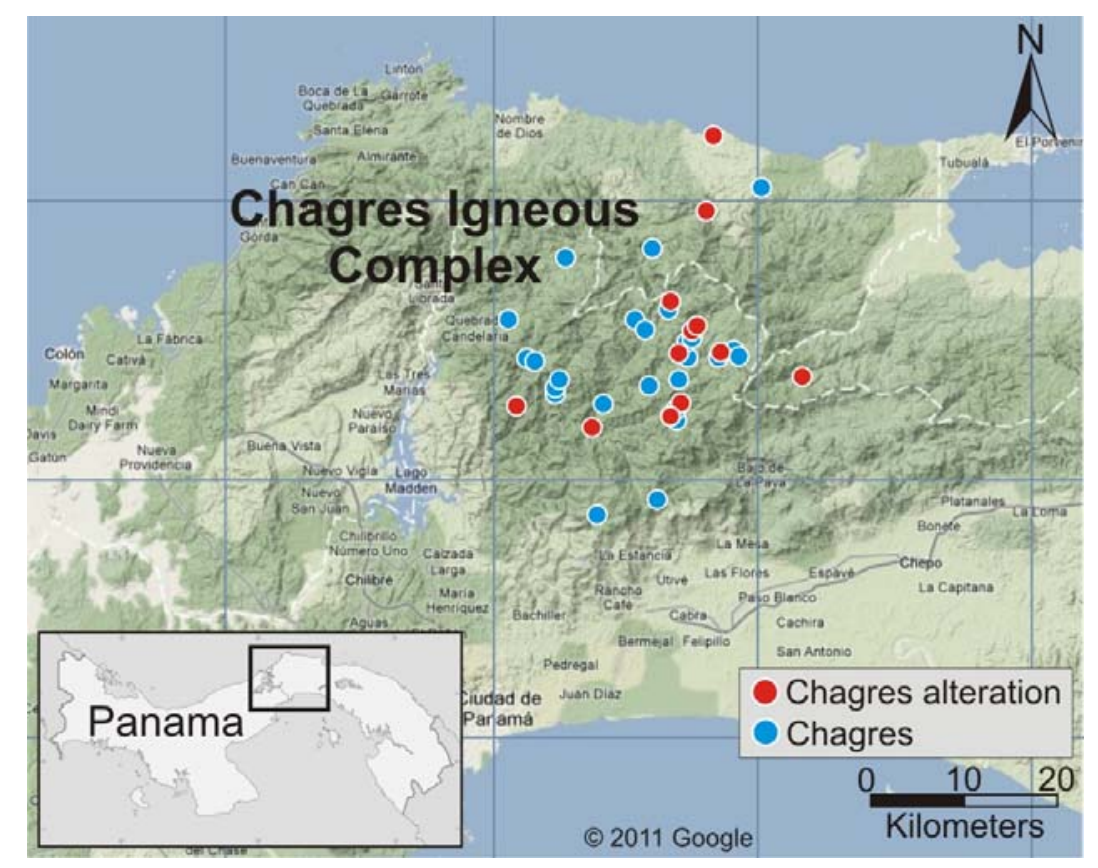

Figure 3.1. Topographic map section of Panama showing the location of the samples taken from the Chagres igneous complex (CHICO). Map based on Google maps 2011.

The electron microprobe JEOL JXA $8900 \mathrm{RL}$ was used for backscattered electron images (BSE) and quantitative wavelength dispersive (WDX) measurements to determine the different secondary mineral phases that formed during hydrothermal alteration. Elemental concentrations in unaltered and altered minerals species were measured to constrain element mobility.

Raman spectroscopy was used for secondary mineral phase determination and was carried out using a Horiba Jobin Yvon LabRam-HR 800 UV micro-Raman spectrometer with a focal length of $800 \mathrm{~mm}$. As excitation wavelength the $488 \mathrm{~nm}$ line of an Argon Ion Laser (Melles Griot IMA 106020B0S) with a laser power of $20 \mathrm{~mW}$ was used.

Whole rock water concentrations were estimated by loss of ignition (LOI). $5 \mathrm{~g}$ of whole rock powder $(<65 \mu \mathrm{m})$ was weighted in and heated over a temperature ramp to $1050{ }^{\circ} \mathrm{C}$ for $24 \mathrm{~h}$. 


\subsection{RESULTS}

\subsubsection{Lithology and Petrology}

The $\mathrm{CHICO}$ is mainly composed of submarine lava flows, dikes, volcaniclastic rocks and coarse grained intrusive rocks of different $\mathrm{SiO}_{2}$ content (Fig. 3.2).

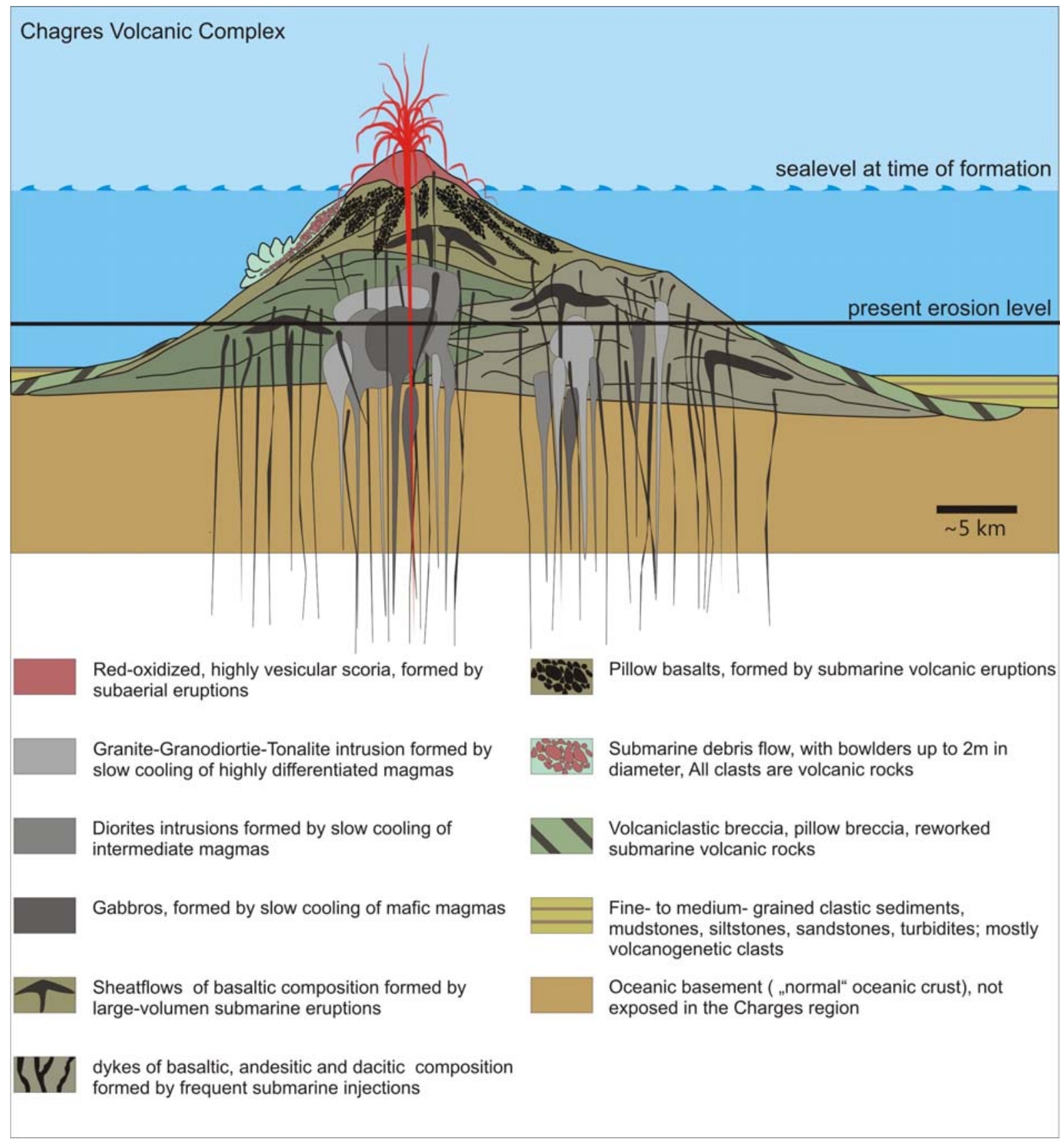

Figure 3.2. Schematic sketch of the Chagres Volcanic Complex a submarine edifice based on the rock units found in the area of the Rio Chagres Basin (3:1 vertical exaggeration). Modified after Wörner et al. (2005).

Most submarine flows are of basaltic to andesitic composition displaying a fine grained vesicle free texture with rare phenocrysts of pyroxene, amphibole and 
plagioclase. The abundance and massive character of the sheet flows and only rare intercalations with pillows and volcaniclastics reflect submarine effusive events with high eruption rates. The volcaniclastic rocks are composed of mainly dense clasts, however rare red vesicular scoria also occurs. The dikes are also mainly of basaltic and andesitic composition and vesicle free. In some places dike swarms are abundant. Often multiple dike inflictions are observed to coalesce into small diorite intrusive bodies. These observations imply again high eruption rates. The dense nature of most of the volcanic rocks argues for an emplacement below the vesiculation depth of $\sim 200 \mathrm{~m}$ for water (Wörner et al., 2005). The intrusive rocks are coarse-grained granites and gabbros whereas the diorites are mostly fine grained micro-diorites. For our alteration study we took samples representing most of the above mentioned lithologies.

Table 3.1. Petrographic composition of the different samples used for alteration investigations.

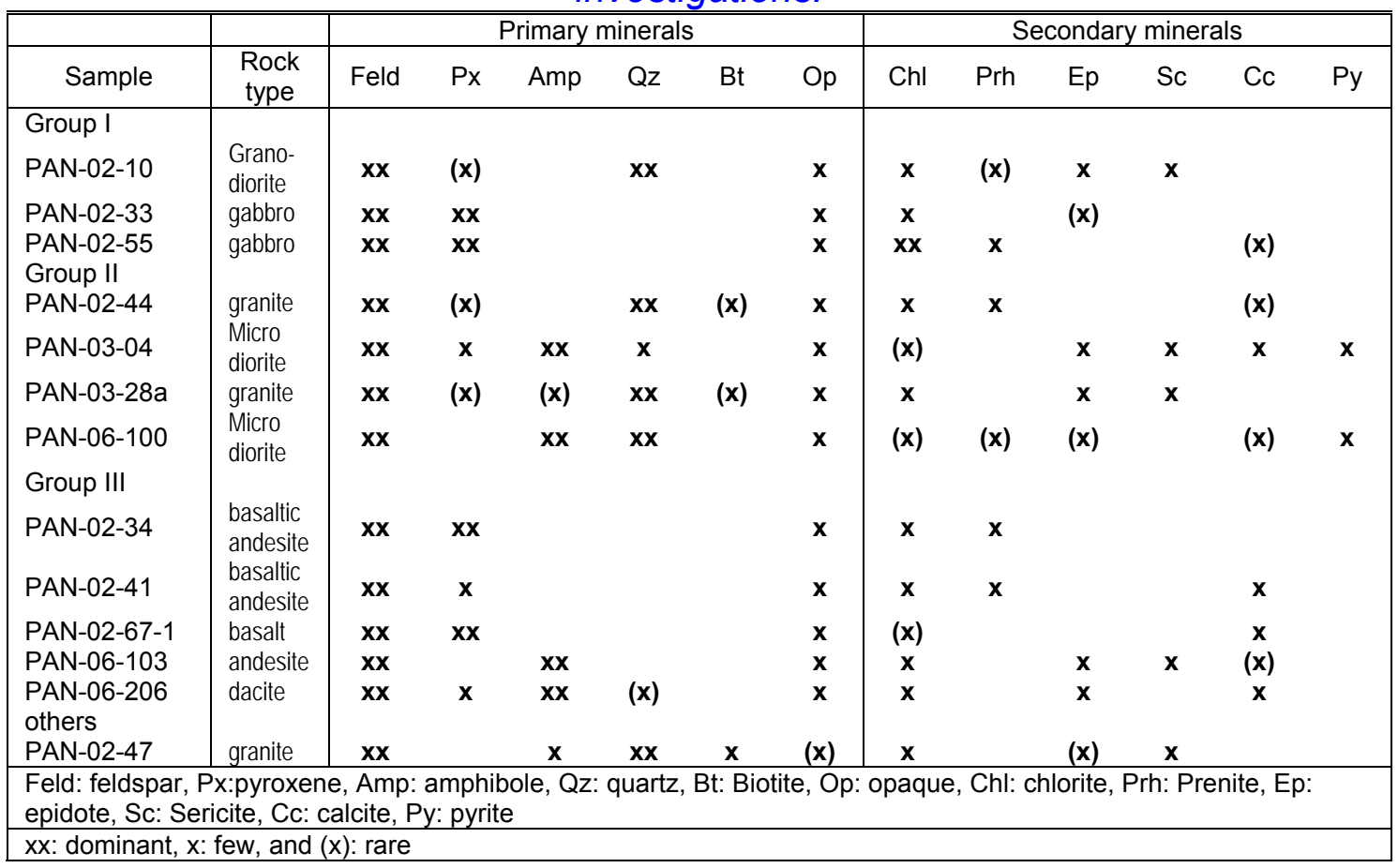

The petrographic composition of the samples is shown in Table 3.1 The dominant igneous phase in all samples is feldspar followed by pyroxene and amphibole. Depending on the degree of differentiation, quartz and biotite are common too. Opaque minerals are present in all samples, however, they contribute only little to the volume. Beside these primary minerals a large variety of secondary alteration minerals are present. Figure 3.3 shows different alteration phenomena in microscope 
scale. The most common secondary mineral is chlorite which comprises between $<1$ and $25 \mathrm{vol} \%$ of the sample. Replacement of pyroxene and amphibole by chlorite is abundant in volcanic and intrusive rocks. The chlorites are sometimes intergrown with prehnite. Many samples show secondary calcite. Most notably calcite is more abundant in volcanic rocks and display significant amounts in the ground mass and in fractures of the phenocrysts. Other common alteration processes are saussuritization and sericitization of plagioclases which are preferentially found in high silica intrusives. Secondary pyrite is also observed in the two micro-diorite samples.

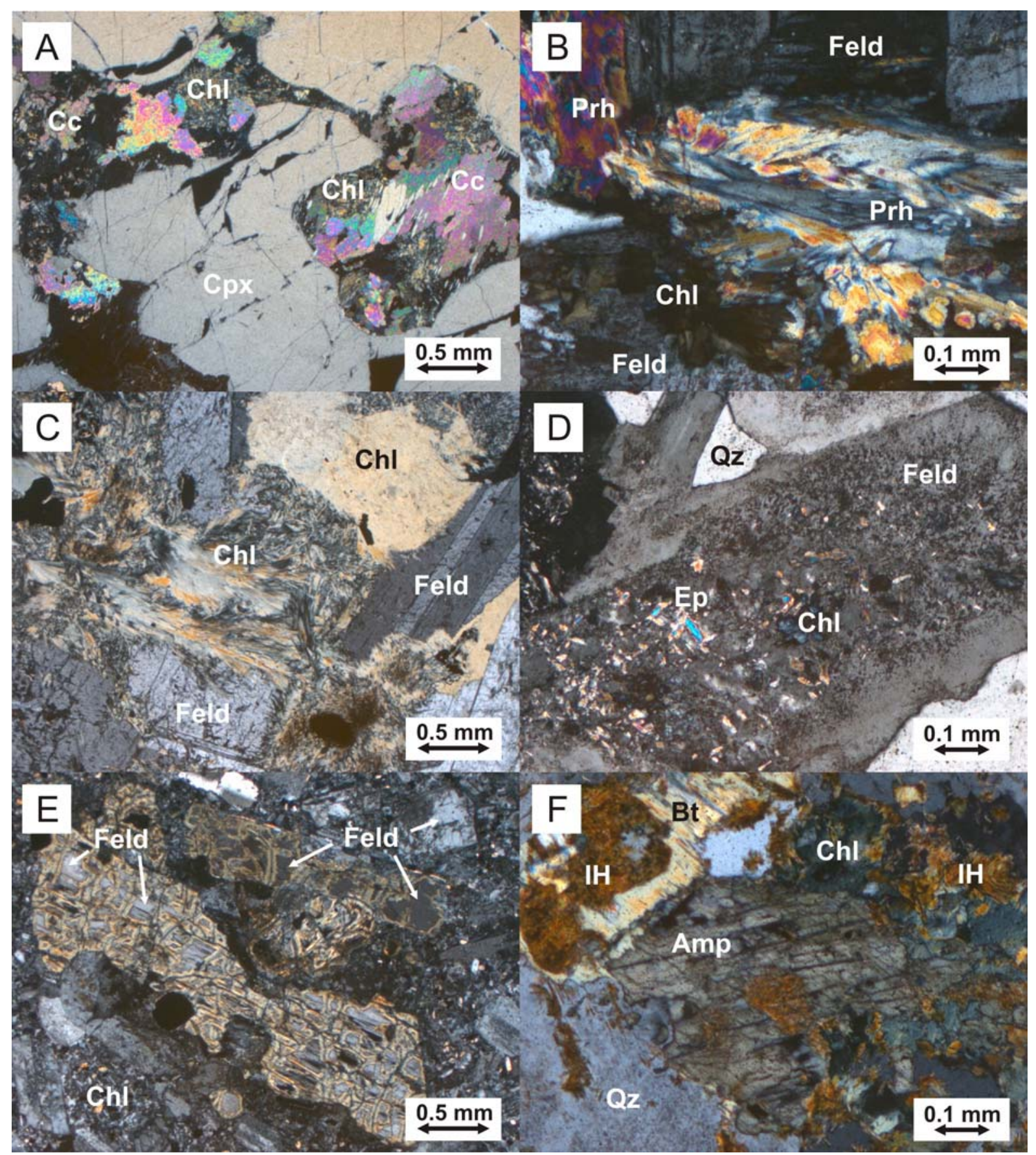


Figure 3.3. (previous page): Photomicrographs of different alteration phenomena in studied rocks. All pictures are taken in crossed-polarized transmitted light. Abbreviations: Cc, calcite; Chl, chlorite; Cpx, clinopyroxene; Prh, prehnite; Feld, feldspar; Ep, epidote; Qz, quartz; Bt, biotite; Amp, amphibole; IH, iron hydroxide. (A) Secondary calcite and chlorite in a basalt fills fractures in a large clinopyroxene phenocryst. (B) Intergrowth of prehnite and chlorite in granite. (C) Typical chlorite in a gabbro showing abnormal brownish or blue-greyish interference colours. (D) Saussuritization of feldspar in granite with epidote and chlorite inclusions. The feldspar is partly altered to pyllosilicates which leads to the greyish structures. (E) Transformation reaction of feldspar in basaltic andesite. (F) Typical alteration pattern in granite with chlorite and iron hydroxides associated with amphibole, biotite and quartz.

According to these observations all samples are affected by secondary low or high temperature alteration. Comparing volcanic and intrusive rocks most alteration takes place in the smaller grain sizes. In both rock types large minerals are less affected than smaller ones except for saussuritization and sericitization. In some volcanic rocks there tend to be two generations of the same mineral (pyroxene and amphibole) some are altered and others are fresh. In conclusion there is a large variety of different minerals and no systematic assemblage has been observed with respect to rock type.

\subsubsection{Oxygen Isotopes}

We analysed ${ }^{18} \mathrm{O} /{ }^{16} \mathrm{O}$ ratios from whole rock powder and minerals for plagioclase, amphibole and clinopyroxene for 13 samples. Measured ${ }^{18} \mathrm{O} /{ }^{16} \mathrm{O}$ are displayed in Table 3.2 using the " $\delta$ "-notation $\left.\delta^{18} \mathrm{O}_{(\%)}=\left({ }^{18} \mathrm{O} /{ }^{16} \mathrm{O}_{\text {sample }} /{ }^{18} \mathrm{O} /{ }^{16} \mathrm{O}_{\text {standart }}-1\right) \times 1000\right)$ relative to VSMOW. Theoretical and experimental mineral-mineral and mineral-melt isotopic fractionations will be used to assess equilibrium considerations between the mineral phases. The samples analyzed span a wide range in bulk composition from $49 \%$ to $77 \% \mathrm{SiO}_{2}$. Figure 3.4 shows the distribution of the $\delta^{18} \mathrm{O}$ values for the different minerals and the whole rocks. $\delta^{18} \mathrm{O}$ values of the extrusive rocks are shifted to significantly higher values compared to the intrusive rocks. This phenomenon is most pronounced in the whole rock and plagioclase samples (Fig.3.4A, C) and less well in the amphiboles. The total range of $\delta^{18} \mathrm{O}$ values is the same for plagioclase $(5.3 \%)$, amphibole $(5.3 \%)$ and whole rocks $(5.4 \%$ ). However most amphiboles tend to have low $\delta^{18} \mathrm{O}$ values $\left(0.8-5.1 \%\right.$ ) but two samples show equilibrium $\delta^{18} \mathrm{O}$ values $(5.5-6.1 \%)$. 


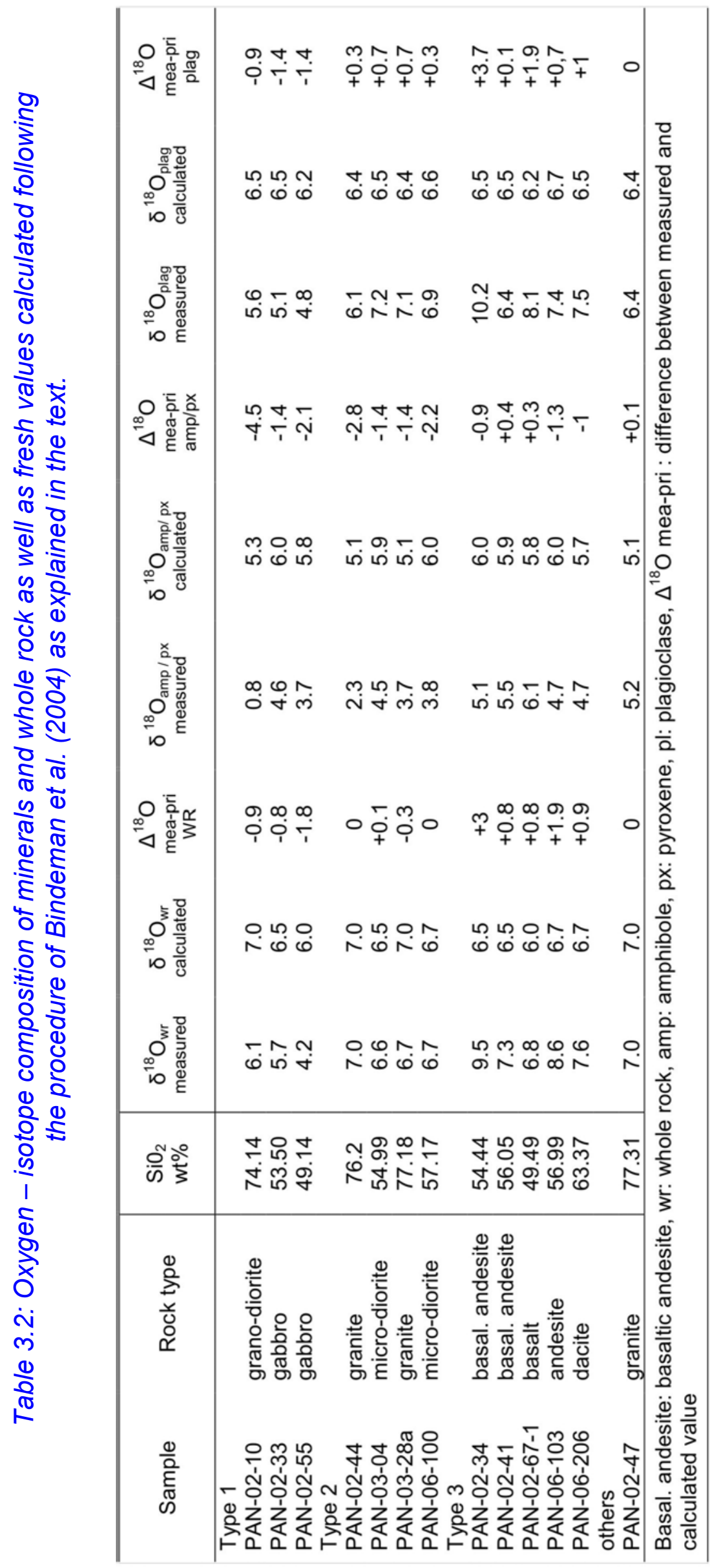


Since analysed samples are clean, handpicked minerals, theses values imply that the magmatic $\delta^{18} \mathrm{O}$ values also should have been low probably caused by assimilation of hydrothermally altered country rock material or a cryptic high temperature alteration which is not recorded as petrographic evidence but in the $\delta^{18} \mathrm{O}$ values (see discussion below). The plagioclases and whole rocks show enriched, depleted and pristine $\delta^{18} \mathrm{O}$ values. A whole rock pristine $\delta^{18} \mathrm{O}$ value in this case is defined as the value expected for a melt of certain $\mathrm{SiO}_{2}$ content without alteration or assimilation influence (see below). Plagioclase $\delta^{18} \mathrm{O}$ values range between $4.8 \%$ and $10.2 \%$ and the whole rocks between $4.2 \%$ and $9.5 \%$.

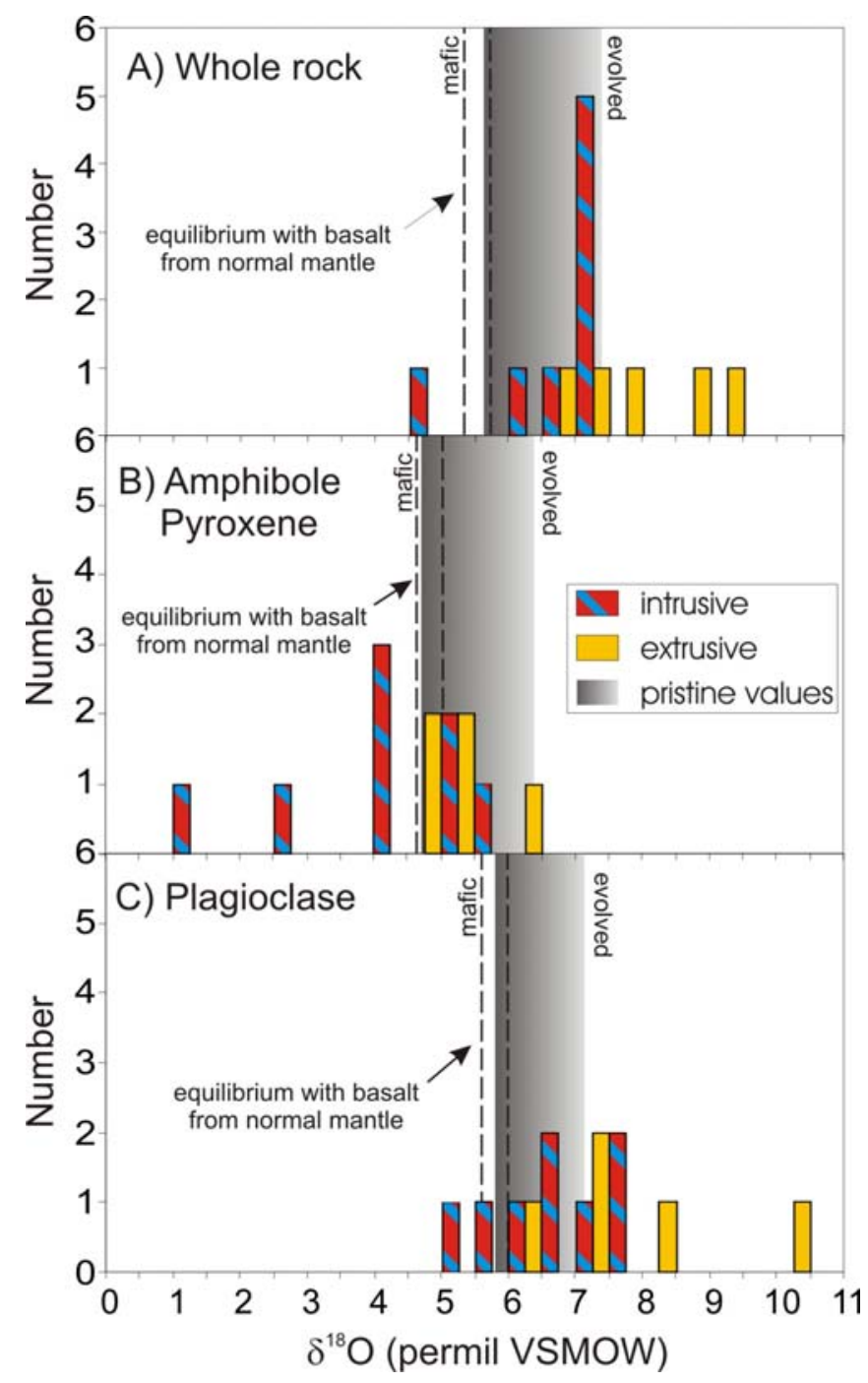

Figure 3.4. Histogram of $\delta^{18} \mathrm{O}$ values illustrating the O-isotope variation in $(A)$ whole rock, (B) amphibole/pyroxene and (C) plagioclase for CHICO rocks. Dark grey displays intrusive rocks, light grey for extrusive rocks. VSMOW - Vienna standard mean ocean water. 
To characterize $\delta^{18} \mathrm{O}$ variations and alteration processes we plotted bulk rock, amphibole/pyroxene and plagioclase $\delta^{18} \mathrm{O}$ values versus the $\mathrm{SiO}_{2}$ content and the water content of the sample (Fig. 3.5). The $\delta^{18} \mathrm{O}$ values are not correlated to $\mathrm{SiO}_{2}$ content with no difference between basalts/gabbros and granites. Only two pyroxenes show extreme low values $(0.8 \%$ and $2.3 \%$ in the granites where as the whole rock (4.2\%o-9.5\%) and plagioclases (4.8\%o-10.2\%o) are in the same range. Overall $\delta^{18} \mathrm{O}$ variations are largest for low silica rocks and slightly decrease towards higher $\mathrm{SiO}_{2}$ values where the baseline formed by the amphiboles/pyroxenes stays constant and the plagioclase and whole rock values decrease. However two pyroxenes fall below the baseline at high $\mathrm{SiO}_{2}$ content and low water content. In addition a gap in sample composition exists in the range from 63-74 wt\% $\mathrm{SiO}_{2}$. The plot of $\delta^{18} \mathrm{O}$ values of the different minerals and the whole rock versus water content shows no trend. However, extrusive rocks show consistently higher water contents than the intrusive rocks with a tendency to higher $\delta^{18} \mathrm{O}$ values. The trends for plagioclase and whole rock $\delta^{18} \mathrm{O}$ values are parallel for most water contents and in the same range, where as the trend for amphibole/pyroxene is different. This observation is consistent with the mass balance because plagioclase is the dominating phase and therefore the plagioclase values dominate the whole rock values. The few amphiboles and pyroxenes are systematically lower, however, they do not affect the whole rock as much as the plagioclase.

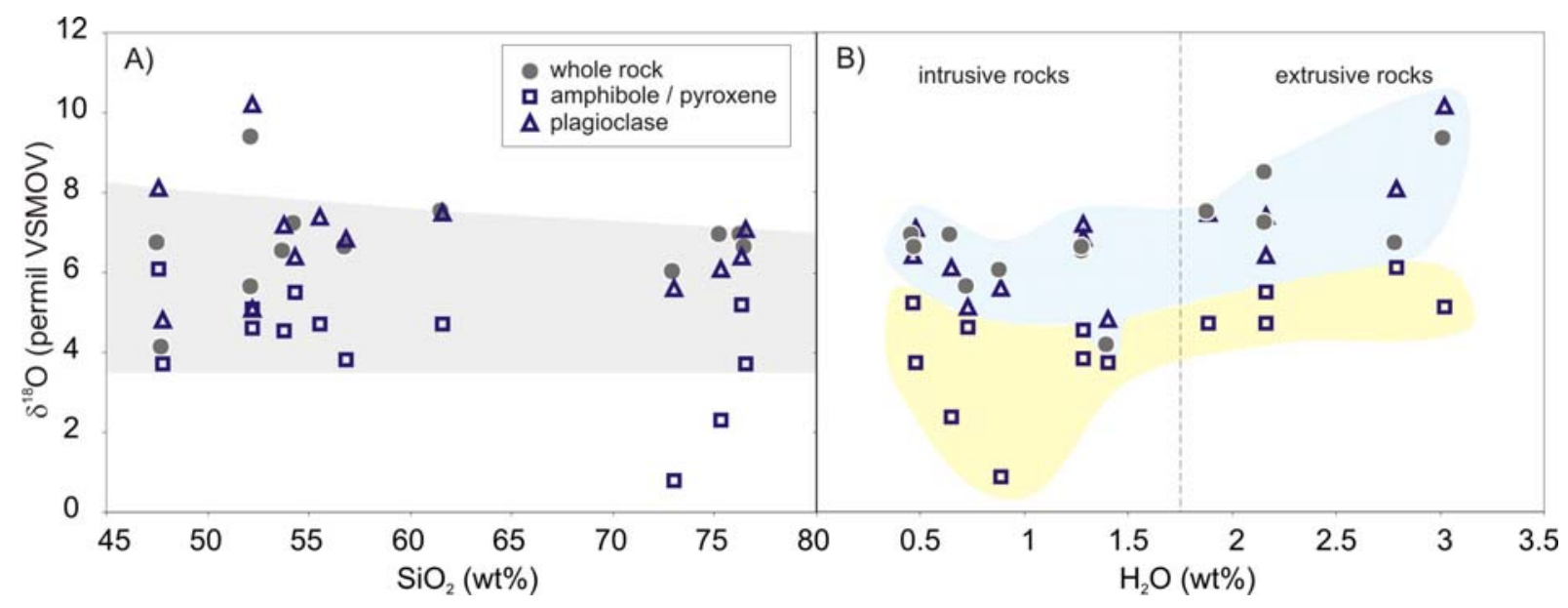

Figure 3.5. Plot of $\delta^{18} \mathrm{O}$ values versus $(A)$ silica content and $(B)$ water content of the whole rock. The data for whole rock, amphibole/pyroxene and plagioclase show no trend with $\mathrm{SiO}_{2}$ and slightly increased values of $\mathrm{H}_{2} \mathrm{O}$ for extrusive rocks relating to intrusive rocks. Shaded areas display sample distribution; grey: all, blue: whole rock and plagioclase, yellow: amphibole/pyroxene. 
To assess different alteration processes and element nobilities we defined some unaltered $\delta^{18} \mathrm{O}$ values for our rocks and minerals. Based on the work of Eiler et al. (1996, 1997, 2000) and Bindemann et al. (2004, 2005), fresh arc basaltic melts should have $\delta^{18} \mathrm{O}$ values in the range of $5.8 \pm 0.2 \%$. Matsuhisa (1979), Harmon and Gerbe (1992) and Bindemann et al. (2004) showed that high-silica dacites and ryolithic melt that was derived solely by closed system fractionation should have higher $\delta^{18} \mathrm{O}$ values up to $\sim 7 \%$. Accordingly, for samples from the Galapágos spreading centre off shore Panama Muehlenbachs and Byerly (1982) found $\delta^{18} \mathrm{O}_{\mathrm{WR}}$ values from 5.9-7.1\%o for mafic and differentiated rocks. Wegner et al. (2011) showed that $\mathrm{CHICO}$ magmas derived from a mantle source that was modified by a few $\%$ of sediments. Therefore we define our pristine melt values $\left(\delta^{18} \mathrm{O}_{\text {melt }}\right)$ for reference to altered rocks as follows: $<52 \mathrm{wt} \% \mathrm{SiO}_{2}=6.0 \%, 52-57 \mathrm{wt} \% \mathrm{SiO}_{2}=6.5 \%$, 57-63 wt $\%$ $\mathrm{SiO}_{2}=6.7 \%$ and $>67 \mathrm{wt} \% \mathrm{SiO}_{2}=7.0 \%$. Our whole rock measurements on fresh samples should represent the melt values however, plutonic rocks may have accumulated crystals. Based on these defined pristine melt values we used the equations developed by Bindemann et al. (2004) to calculate the pristine mineral values for plagioclase, amphibole and pyroxene.

$\delta^{18} O_{a m p h / p x}=\delta^{18} O_{\text {melt }}-\left(0.061 * \mathrm{SiO}_{2}(w t \%)-2.27\right)$

$\delta^{18} O_{\text {plag }}=\delta^{18} O_{\text {melt }}-\left(0.027 * \mathrm{SiO}_{2}(w t \%)-1.45\right)$

The thus equated mineral values are only approximations not taking directly into account the anorthite - albite ratio of the plagioclase, and the variation value of $\mathrm{Mg} / \mathrm{Fe}$ ration of amphibole and pyroxene. To take this into account we allowed for a uncertainty of $\pm 0.4 \%$ for the individual pristine values.

The equated pristine $\delta^{18} \mathrm{O}$ values were compared with the measured ones. We found distinct differences which were beyond the allowed uncertainty. Based on these findings we define tree different groups of samples (Tab. 3.2). The first group is the most coherent in terms of $\delta^{18} \mathrm{O}$ values and consists of three samples: a granodiorite $\mathrm{PAN}-02-10$, and two gabbros PAN-02-33 and PAN-02-55. Theses samples are characterized by low whole rock $\delta^{18} \mathrm{O}$ values which range between $4.2 \%$ and $6.1 \%$, low amphibole $\delta^{18} \mathrm{O}$ values from $0.8 \%$ to $4.6 \%$ and low plagioclase $\delta^{18} \mathrm{O}$ values in the range between $4.8 \%$ and $5.6 \%$. The main characteristics of this group are therefore low $\delta^{18} \mathrm{O}$ values for all measured phases, which imply that these rocks 
contain a component that underwent high temperature hydrothermal alteration which leads to the ${ }^{18} \mathrm{O}$-depletion. For further details see the discussion.

The second group is characterised by uniform whole rock $\delta^{18} \mathrm{O}$ values at typical values (6.6 \%o $-7.0 \%$ ) but low $\delta^{18} \mathrm{O}$ values for amphiboles/pyroxenes $(2.3 \%$ \%-4.5 \%o). The $\delta^{18} \mathrm{O}$ values for plagioclase are either slightly elevated or pristine $\left(6.1 \% \mathrm{o}^{-7.2} \%\right.$ o). This group comprises two granites (PAN-02-44 and PAN-03-28a) and two diorites (PAN-03-04 and PAN-06-100). These results are consistent with a combination of high temperature and low temperature hydrothermal alteration.

The unique feature of the third group is the high whole rock $\delta^{18} \mathrm{O}$ values in the range between $6.8 \%$ and $9.5 \%$. The amphibole/pyroxene $\delta^{18} \mathrm{O}$ values are low or pristine (4.7\%o-6.1\%o) and for the plagioclases mainly high between $7.4 \%$ and $10.2 \%$ except of PAN-02-41 which shows a pristine value of $6.4 \%$. This group contains five volcanic samples and is composed of a basalt (PAN-02-67-1), two basaltic andesites (PAN-02-34 and PAN-02-41), an andesite (Pan-06-103) and a dacite (PAN-02-206). The data suggest again a combination of high temperature and low temperature hydrothermal alteration. However this alteration is different from that of type 2. The $\delta^{18} \mathrm{O}$ values for whole rocks and minerals are generally more enriched than in the second group. For whole rock and plagioclase values this leads to the highest differences between the calculated pristine $\delta^{18} \mathrm{O}$ values and the measured values. For amphibole/pyroxene in contrast the differences are the smallest. These results suggest a stronger influence of the low temperature hydrothermal alteration particularly reflected in the plagioclase compared to group two samples.

One granite sample does not fit any of the three groups (PAN-02-47). From the oxygen isotope point of view the sample PAN-02-47 looks completely pristine. All oxygen values for whole rock (7.0\%), amphibole (5.2\%) and plagioclase (6.4 \%o) are within the pristine range. However this sample is not pristine at all. Petrographic observation shows abundant secondary chlorite, dirty brownish to greyish plagioclases with pyllosilicates and epidote inclusions and remarkable ion hydroxides (Fig. 3.3F). Taking these facts into account it seems that only by mere chance the combination of different alteration processes lead to pristine $\delta^{18} \mathrm{O}$ values. Therefore we treat this sample as an altered one, however, we cannot integrate it in one of the above groups.

In order to interpret major- and trace element mobility in the following, we need some unaltered reference samples which we identify by $\delta^{18} \mathrm{O}$ values and petrography. In 
the case of gabbro PAN-03-07 the whole rock and amphibole $\delta^{18} \mathrm{O}$ values are pristine but the plagioclase values are low. Petrographic inspection shows that most of the sample is free of alteration. The amphiboles are fresh, there is almost no chlorite, most plagioclases appear unaltered only a few are cloudy and there are only rare other secondary phases. However, rare pyroxenes show some alteration to chlorite. Even though we hand picked clean mineral separates it seems possible that the measured plagioclase oxygen isotopes values are affected by the rare cloudy plagioclases. The samples PAN-03-29 and PAN-04-04 a basaltic andesite and an andesite show pristine $\delta^{18} \mathrm{O}$ values for pyroxene and plagioclase, (no whole rock measured). There are a few secondary phases and alteration features in the thin section similar as in the sample PAN-03-07. For the granite PAN-02-45 the oxygen data for minerals and whole rock are missing however the petrography shows the least altered composition of all granites analysed in the $\mathrm{CHICO}$ and thus we also include this sample for trace element reference. Based on these observations we define these samples (PAN-03-07, PAN-03-29, PAN-04-04, PAN-02-45) as nearly unaltered and use them as reference for the chemical element mobility considerations later in this study.

The granite samples PAN-02-47 and gabbro PAN-03-07 show that it is difficult from $\delta^{18} \mathrm{O}$ values alone to assess alteration. It is really necessary to combine petrographical and oxygen isotope evidence of different phases and whole rocks to evaluate alteration of a rock sample.

\subsubsection{Tropical Weathering}

In the case of the CHICO located in the tropic rain forest in Panama, tropical weathering is a possible process for element mobilization and oxygen isotope changes. Based on Striepe (2007) we can almost entirely exclude weathering phenomena for our samples. He studied element mobility of a gabbro sample with characteristic weathering crust from the CHICO area. Based on La-ICPMS and EMS measurements it was found that during weathering processes certain elements are almost completely leached from the rocks. He described the processes with regard to element mobility and petrography. The mobile behavior for the different elements is as follows: $\mathrm{Ca}>\mathrm{Na}>\mathrm{K}, \mathrm{Rb}, \mathrm{Sr}>\mathrm{Ba}>\mathrm{La}>(\mathrm{Ce})>\mathrm{Pr}>\mathrm{Nd}>\mathrm{Sm}>(\mathrm{Eu})>\mathrm{Y}, \mathrm{Sc}>$ $\mathrm{Gd}>\mathrm{Tb}>\mathrm{Dy}>\mathrm{Ho}>\mathrm{Er}>\mathrm{Tm}>\mathrm{Yb}>\mathrm{Lu}>\mathrm{Cr}, \mathrm{Mn}$, Fe, Co, Zn $>$ As, Sb, Ge, Ga $>\mathrm{U}$, $\mathrm{Th}>\mathrm{Hf}, \mathrm{Zr}, \mathrm{V}>\mathrm{Ta}, \mathrm{Nb}$. This means for example an inverse behavior of $\mathrm{K}$ and $\mathrm{U}$ 
compared to low temperature alteration (Alt et al., 1996; Staudigel et al., 1996). However the main point for our study is that the weathering is restricted to a ca. $3.5 \mathrm{~cm}$ wide layer which was exposed to the surface. Deeper in the sample only unweathered, homogeneous values are detected which reflect the composition of the variably altered gabbro. This finding implies that weathering effects can be excluded if samples do not contain the weathering rinds which are optically easy to distinguish form the unweathered rock. Our sampling method accounted for that, therefore we can ignore this tropical weathering as a cause for element mobilization.

For the oxygen isotopes this general statement cannot be made because for $\delta^{18} \mathrm{O}$ no data are available form that study. With respect to oxygen isotopes low temperature surface weathering leads to enrichment in ${ }^{18} \mathrm{O}$ in the whole rock (Hoefs, 2009).

\subsubsection{Major Elements versus Alteration Proxies}

Major- and trace-element compositions for 13 whole-rock samples are reported in Table 3.3. The samples range in composition from gabbro to granite and from basalt to dacite (Fig. 3.6A). The intrusive rocks belong to the low- $\mathrm{K}$ tholeiitic series and the extrusive rocks plot directly on the border between low-K tholeiitic and medium-K calc-alkaline series (Fig. 3.6B). The bulk rock compositions of the samples represent the large variety of composition present in the $\mathrm{CHICO}$.
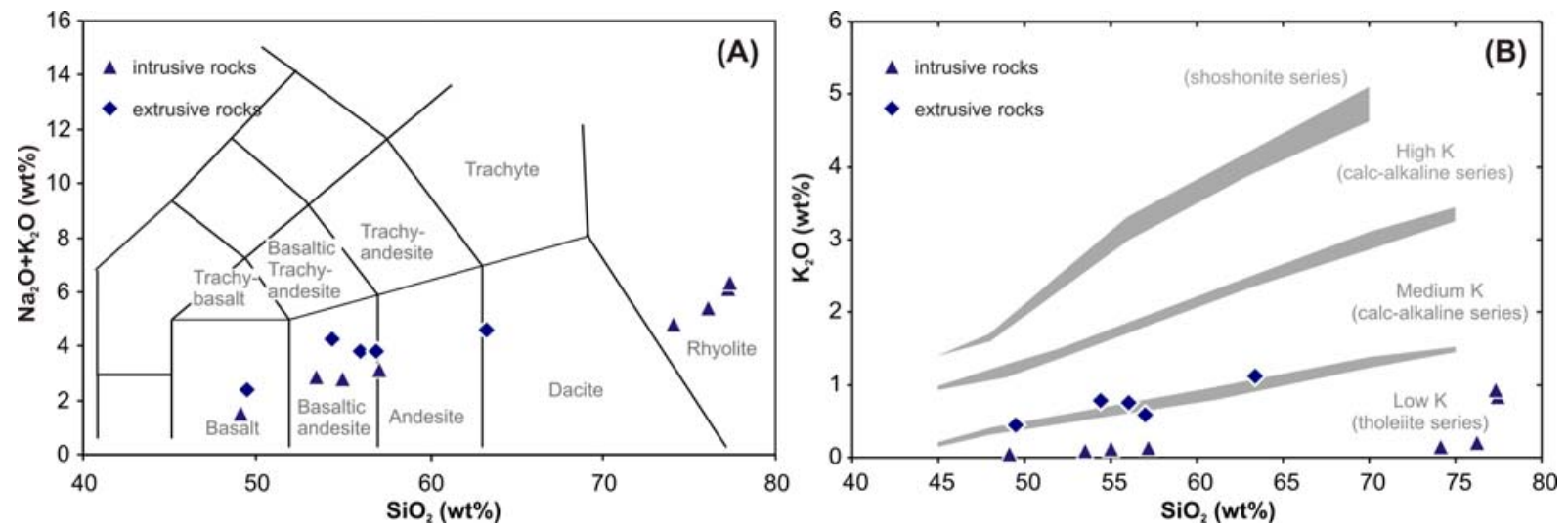

Figure 3.6. Chemical classification and nomenclature of volcanic rocks. (A) Total alkali verus silica (TAS) diagram according Le Maitre et al.(1989) and (B) Subdivison of subalkaline rocks after Rickwood (1989).

With regard to alteration selected element ratios are plotted versus the two available alteration tracers: water content and $\delta^{18} \mathrm{O}$ value (Fig. 3.7). The potential effect of alteration is expressed as $\Delta^{18} \mathrm{O}$ measured-pristine which is here defined as the difference 
between the measured $\delta^{18} \mathrm{O}$ value and the calculated pristine $\delta^{18} \mathrm{O}$ value for the respective composition. The pristine composition is estimated following the approached described earlier. All deviations are expressed as positive values. However this parameter is not a simple alteration indicator like water content displaying increasing alteration with increasing value. For $\Delta^{18} \mathrm{O}$ measured-pristine values superimposed high and low temperature processes can not be resolved and would potentially cancel each other out.
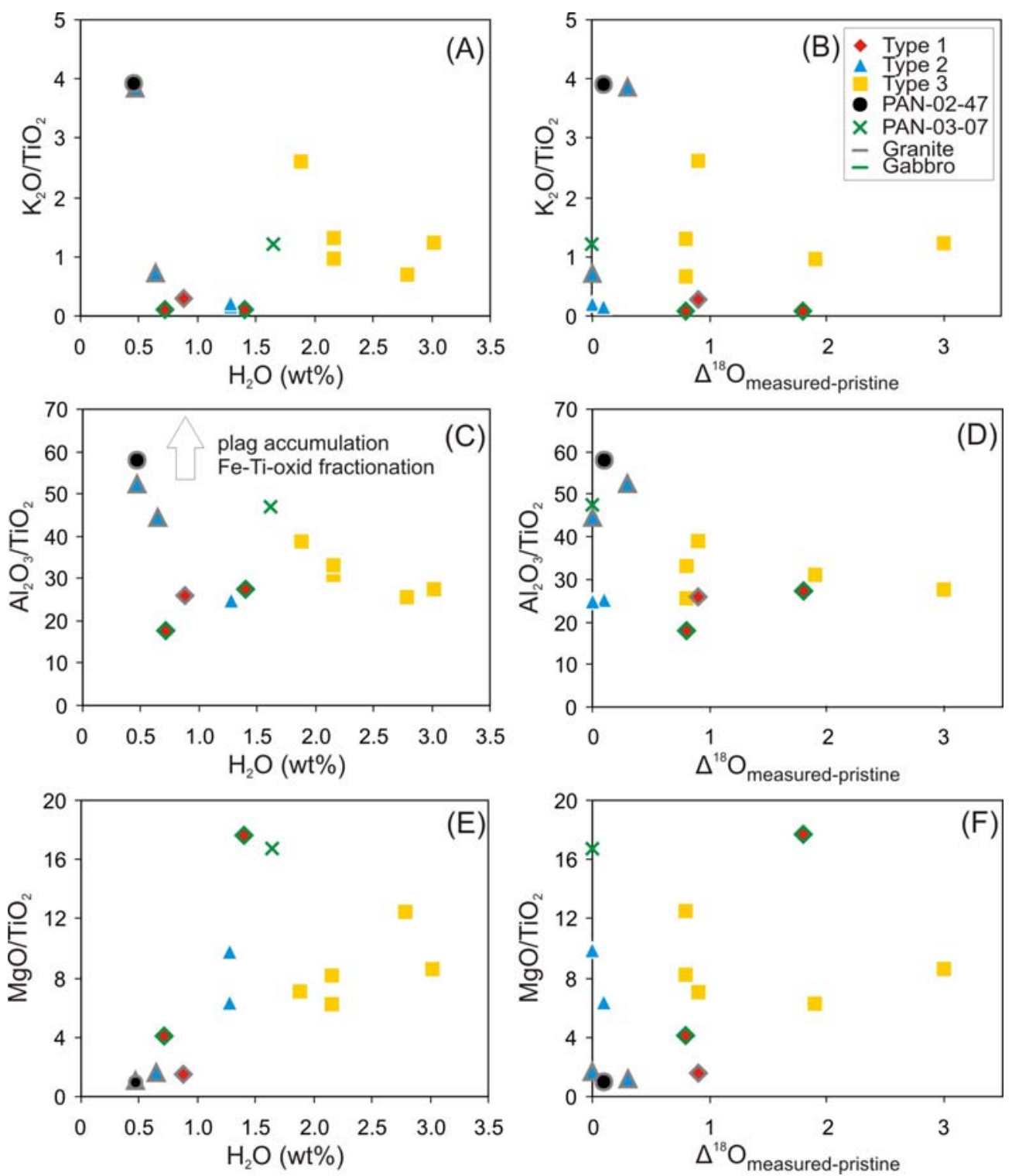

Figure 3.7. Variation of major element ratios relative to the two alteration proxies water content and positive $\Delta^{18} \mathrm{O}$ measured-pristine which is defined as the difference between the measured $\delta^{18} \mathrm{O}$ whole rock values and the defined pristine $\delta^{18} \mathrm{O}$ whole rock value (see text for details). $(A)+(B) A$ mobile element versus immobile, $(C)+(D)$ two immobile elements and $(E)+(F)$ a intermediate element versus an immobile. Colours indicate different alteration groups based on $\delta^{18} \mathrm{O}$ values. 
Following the work of Bach et al. (2001) we choose $\mathrm{TiO}_{2}$ as our normalization value. $\mathrm{Ti}$ and $\mathrm{Al}$ were tested against all other elements to identify the most immobile reference element. Ti appears to be best, however, there are some variations with differentiation (Fe-Ti-oxid-fractionation) and plagioclase accumulation. The ratio $\mathrm{Al}_{2} \mathrm{O}_{3} / \mathrm{TiO}_{2}$ shows the ratio of two immobile elements (Fig. 3.7A, B). The ratio does not show any correlation with the alteration tracers as expected. In fact, the ratio should be more or less constant for mafic samples. The highest values are observed for granites due to Ti-oxid-fractionation. The scatter in concentration of the less differentiated samples is attributed to the highly variable bulk rock compositions, inherited from the different mantle sources and slightly influenced by differentiation processes and therefore most likely not caused by alteration.

In the case of $\mathrm{K}_{2} \mathrm{O} / \mathrm{TiO}_{2}$ (Fig. 3.7C, D) a mobile element $\left(\mathrm{K}_{2} \mathrm{O}\right)$ is normalized to an immobile element $\left(\mathrm{TiO}_{2}\right)$. For a clear alteration signal variable but increasing $\mathrm{K}_{2} \mathrm{O}$ is expected with increasing alteration at low temperature conditions (Bednarz and Schmicke, 1989; Alt et al., 1996; Staudigel et al., 1996; Nakamura et al., 2007). However Seyfried and Mottl (1982) found a loss of $\mathrm{K}_{2} \mathrm{O}$ at low temperature in their experiments. A different behaviour is expected for high temperature conditions where Bednarz and Schmicke (1989) as well as Nakamura et al. (2007) found depletion in $\mathrm{K}_{2} \mathrm{O}$ with increasing alteration. However such trends are not observed. For samples with low water content and small $\Delta^{18} \mathrm{O}$ measured-pristine values of the whole rock a large variation in $\mathrm{K}_{2} \mathrm{O}$ content is observed. The type 1 samples which are only affected by low temperature alteration (see discussion below) show relatively small scatter in both alteration proxies. Type 2 and 3 show a decrease in $\mathrm{K}_{2} \mathrm{O} / \mathrm{TiO}_{2}$ with increasing water content. In terms of $\Delta^{18} \mathrm{O}$ measured-pristine values the variation in $\mathrm{K}_{2} \mathrm{O}$ is largest in the type 2 samples and less pronounced in type 3 . No clear distinction between the different groups is recognized, however.

The $\mathrm{MgO} / \mathrm{TiO}_{2}$ ratio (Fig. 3.7E, $\mathrm{F}$ ) is representative for the behaviour of an element which is slightly mobile during low temperature and high temperature alteration and decreases with increasing alteration under low temperature conditions (Muehlenbachs and Clayton, 1972; Bach et al., 2001).

For high temperature alteration Nakamura et al. (2007) proposed enrichment of MgO with increasing alteration. The groups show internally high variations and inconsistent behaviour between water and $\Delta^{18} \mathrm{O}_{\text {measured-pristine values. }}$ 
Table 3.3. Major, minor and trace element bulk rock composition.

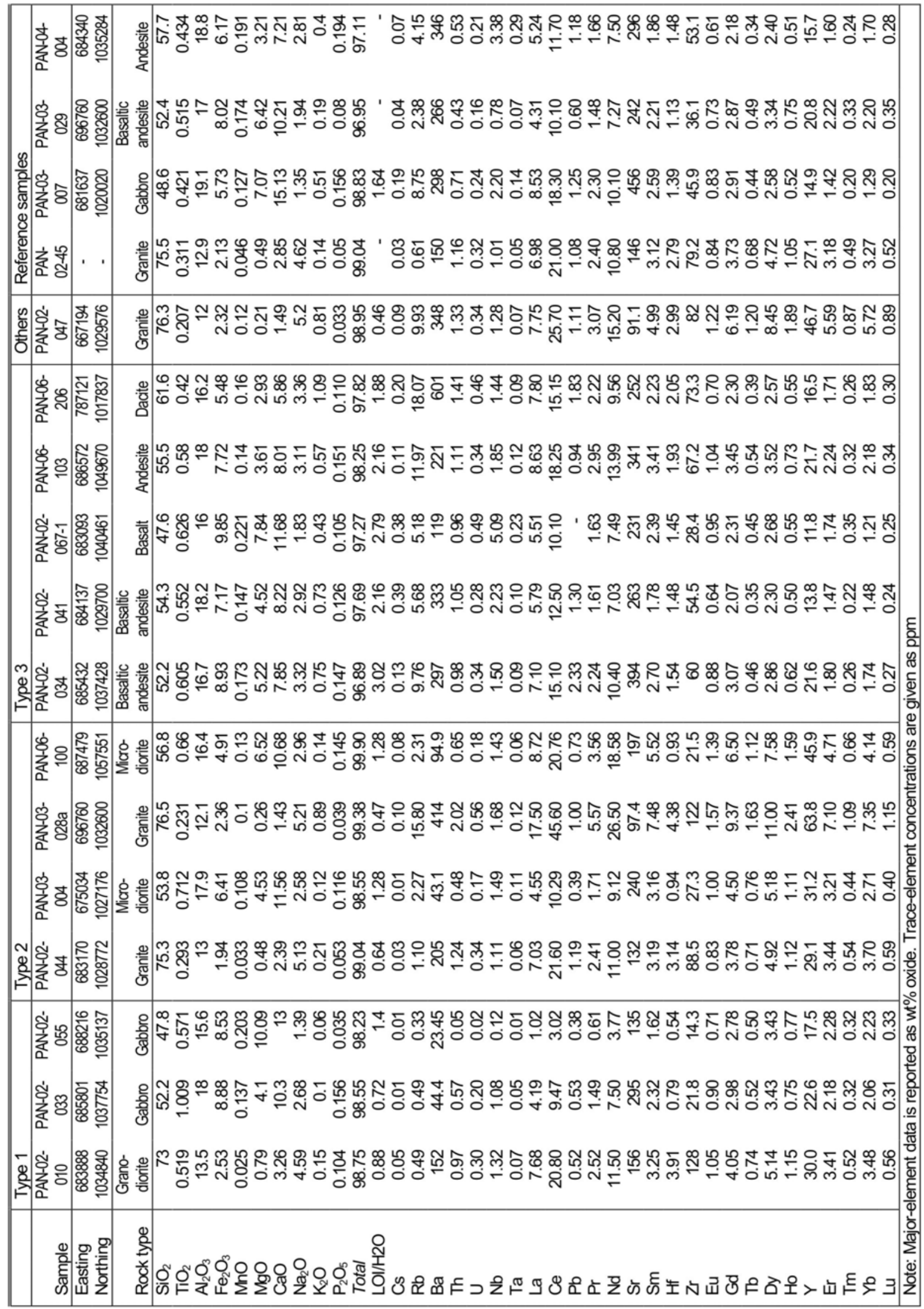


An increase in $\mathrm{MgO}$ is observed for increasing $\mathrm{H}_{2} \mathrm{O}$ for type 2 and 3 . For $\Delta^{18} \mathrm{O}$

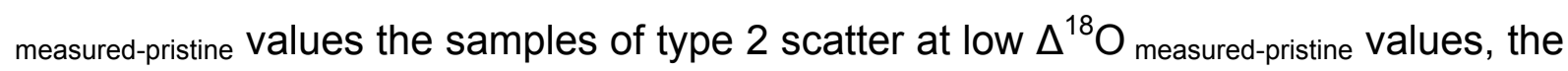
type 1 samples show a roughly negative trend and the type 3 forms a more or less horizontal array with moderate scatter.

\subsubsection{Trace Element variations due to Source variation, Slab fluid and Alteration}

In Figure 3.8A the trace elements are plotted in a multi element diagram normalized to primitive mantle. The plot shows a clear subduction signature expressed by the $\mathrm{Nb}$, Ta trough and the high enrichment peaks for the fluid mobile elements $\mathrm{Cs}, \mathrm{Rb}$, $\mathrm{Ba}, \mathrm{K}, \mathrm{Pb}$ and $\mathrm{Sr}$. Ti shows a negative peak which is attributed to differentiation. Variable $\mathrm{Nb}$ and $\mathrm{Ta}$ values indicate the variation in the mantle source composition (Wegner et al., 2011), because these elements are immobile and should not changed during slab fluid addition and alteration. As illustrated by the rare earth elements (REE) and $\mathrm{Nb}$ and $\mathrm{Ta}$ (excluding sample PAN-02-55) the source variations are relatively large, however, some of the variation is attributed to differentiation. The mobile large-ion-lithophile elements (LIL) like $\mathrm{Cs}, \mathrm{Ba}, \mathrm{Rb}, \mathrm{Pb}$ and $\mathrm{Sr}$ are expected to show enrichment due to slab fluid addition displayed as peaks in the spider diagram. Some samples show negative peaks in these elements what is attributed to alteration. From this observation we know that alteration influences the mobile elements.
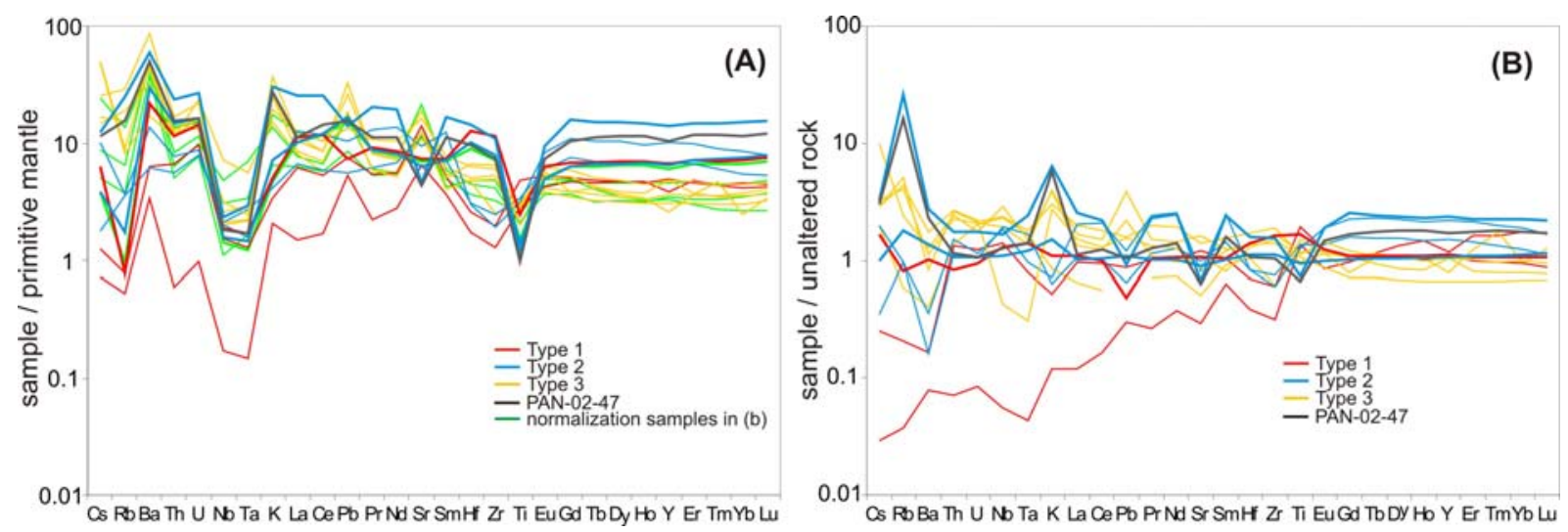

Figure 3.8. Trace element patterns, for all analysed samples from the CHICO. Values in (A) normalized to Sun and McDonough (1989) primitive mantle, in (B) normalized to least altered sample of similar rock type and differentiation degree. Elements are plotted according to their decreasing incompatibility from left to right. Colours indicate different alteration types based on $\delta^{18} \mathrm{O}$ values. Bold lines indicate granites. 
The samples of the different alteration groups show variations in both, source composition and the degree of fluid enrichment in addition to variable alteration.

In Figure 3.8B the samples are normalized to a least altered sample the of same differentiation degree to account for differentiation and different initial trace element patterns. However, the inhomogeneous source composition and the variable slab fluid enrichment still will lead to differences between samples that are not dependent on alteration (see discussion for detail). The gabbro PAN-02-55 is the most depleted sample in the CHICO. In the whole dataset (Wegner et al., 2011) seven samples fill the gap between this most depleted one and the majority of the samples displayed here. For this sample PAN-02-55 the effect of a depleted source composition of the trace elements is so extreme that consideration of alteration is not possible. However for major elements and oxygen isotopes this sample is normal.

In the following the mobile elements will be examined for their behavior during low and high temperature alteration conditions. A special focus is laid on the type 1 samples because they are only affected by high temperature alteration. The low $\delta^{18} \mathrm{O}$ values of all samples can only explained by either high temperature alteration or assimilation of material which was altered under high temperature conditions (see discussion for details). The Cs values of all types are variable. Type 1 and 2 samples show enrichment and depletion, type 3 shows enrichment for all samples. For Cs Alt et al. (1996) and Staudigel et al. (1996) postulate enrichment in the rock for low temperature alteration. For high temperature alteration only experimental data are available (Seyfried et al., 1998) which indicate Cs depletion. A simple interpretation based on the literature data is thus not possible for our data. For $\mathrm{Rb}$ the type 1 samples are highly depleted. Type 2 and 3 rocks show mainly enrichment and few slightly depleted values. Type 1 depletion is consistent with literature data of high temperature hydrothermal alteration (Nakamura et al., 2007; James et al. 2003). The effect for low temperature hydrothermal alteration is opposite to high temperature alteration (Alt et al., 1996; Staudigel et al., 1996). Alt and Teagle (2003) showed enrichment for $\mathrm{Ba}$ under low temperature alteration conditions whereas Seyfried and Mottl (1992) found depletion in their experiments. For high temperature alteration depletion is observed (Nakamura et al., 2007; Mottl and Holland, 1978). Type 1 samples are depleted or unchanged in Ba which is consistent with high temperature alteration. Type 2 and 3 samples show variable depletion and enrichment. Chen et al. (1986) described the behavior of $\mathrm{Pb}$ during hydrothermal alteration as variable. 
Depletion is proposed by Michard and Alberede (1985) for high temperature hydrothermal alteration. Our samples show depletion for all samples of type 1 and enrichment for most of the type 3 samples. Type 2 samples scatter around unchanged values with only minor enrichment and depletion. Sr mobility during high temperature hydrothermal alteration is poorly defined. Nakamura et al. (2007) found depletion, James et al. (2003) found enrichment and Mottl and Holland (1978) found both depletion and enrichment depending on experiment conditions. Our high temperature alteration samples of type 1 show weak enrichment. During low temperature alteration Sr should be depleted (Christidis, 1998; Seyfried and Mottl, 1982; Alt and Teagle, 2003). This trend is shown by the type 2 samples which are all weakly depleted. For type 3 samples we observe enrichment and depletion. The variation in $\mathrm{Sr}$ content is smallest compared to the other mobile elements.

Trace element variations that can be partly ascribed to alteration thus do not behave systematically in the different types defined on the basis of their $\delta^{18} \mathrm{O}$-systematics. At least type 1 samples should show a coherent enrichment and depletion behavior because they are only affected by high temperature alteration. Since the other two types show combinations of variably intense high temperature and low temperature alteration, no systematic trace element variations are expected.

Taking all the information from major and trace elements in account, we conclude that we can not easily resolve changes in element bulk rock composition caused by alteration and allocate these to high and low temperature conditions of alteration. The sequential processes under changing thermal conditions (on top of already inhomogeneous source material) lead to different and partly contrasting exchange processes of the major and trace elements.

\subsubsection{Influence of primary Petrography on Alteration}

The dataset comprises intrusive and extrusive samples as well as differentiated and mafic samples. Mineral alteration is independent of primary rock type. Based on $\delta^{18} \mathrm{O}$ values the alteration is independent from the degree of differentiation. We find mafic and differentiated samples displaying the same alteration type. However there is a difference between extrusive and intrusive rocks. The extrusive rocks form an exclusive group with the special alteration type 3 . The extrusive rocks are also characterized by the highest water contents. 
Mobility of major and trace elements are independent of the nature of the parent rock during alteration which is in contrast to findings by Christidis (1998). The extrusive rocks form the most coherent group in alteration patterns, however, they do not display particular features. We can conclude that the degree of differentiation is irrelevant for alteration but the emplacement mechanism is important. Extrusive emplacement leads to direct contact with high quantities of low temperature seawater. Thus the main difference between alteration of intrusive and extrusive rocks is temperature and the water rock ratio which is lower, respectively higher for the extrusive rocks.

\subsection{DISCUSSION}

\subsubsection{Genesis of low $\delta^{18} \mathrm{O}$ Values}

The most unusual feature of the measured samples is the relatively depleted $\delta^{18} \mathrm{O}$ values for amphiboles and pyroxenes, in reference to mantle melt values in all groups. Three processes are known to produce low $\delta^{18} \mathrm{O}$ values: (1) $\mathrm{A}$ low $\delta^{18} \mathrm{O}$ mantle source (Macpherson et al., 2000), (2) contamination of low $\delta^{18} \mathrm{O}$ wall rocks produced by hydrothermal alteration (Thirlwall et al., 1997; Garcia et al., 1998; Eiler et al., 1996, 2005), and (3) high temperature hydrothermal alteration (McCulloch et al., 1980).

If the low $\delta^{18} \mathrm{O}$ values are indeed magmatic, then equilibrium should be observed among the coexisting mineral phases. In Contrast we observe a significant heterogeneity of the different mineral phases. Some phases show low values some, pristine and some high $\delta^{18} \mathrm{O}$ values. For a mantle source signal the mineral phases should be in mutual equilibrium and the $\delta^{18} \mathrm{O}$ values should correlated to $\mathrm{SiO}_{2}$ which is not the case here. Therefore we exclude the influence of a primarily depleted mantel source.

The second possibility, assimilation of a young high-T hydrothermally altered crust or slab component, is also not detectable. There is no correlation of decreasing $\delta^{18} \mathrm{O}$ with increasing $\mathrm{SiO}_{2}$. Crustal contamination in variably evolved magmatic rocks generally increases with the extent of differentiation (Taylor, 1980). Therefore differentiated samples are expected to show systematically lower $\delta^{18} \mathrm{O}$ values than mafic rock if crustal contamination involves low $\delta^{18} \mathrm{O}$ altered country rock.

Having excluded a primary depleted source and assimilation for most rocks, we favor the third alternative. The low $\delta^{18} \mathrm{O}$ values of amphiboles and pyroxenes are attributed 
to a dominantly high temperature hydrothermal alteration. This is consistent with all facts observed for petrographically altered minerals.

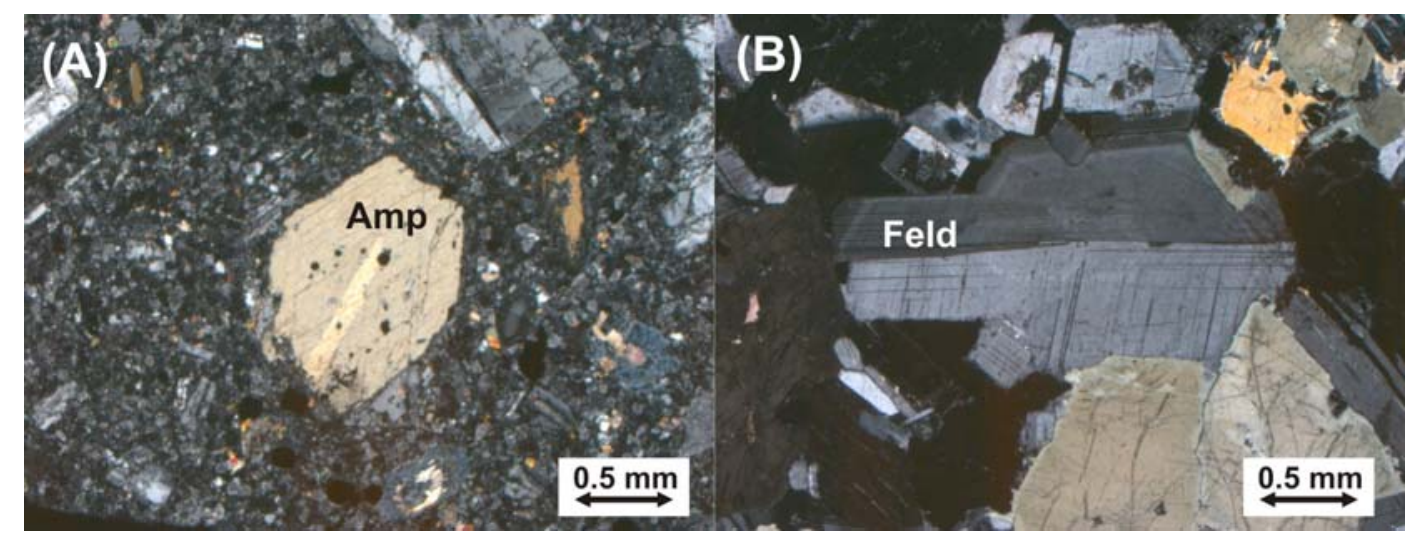

Figure 3.9. Photomicrographs of two fresh minerals without alteration aspects and solution-precipitation signs however characterized by low $\delta^{18} \mathrm{O}$ values. (A) Amphibole from PAN-06-206 dacite and (B) feldspar from PAN-03-04 microdiorite.

However there is a group of minerals from different samples which look absolutely fresh but display low $\delta^{18} \mathrm{O}$. Diffusion as an exchange process is ineffective and solution-precipitation processes can be excluded by microscopy (Fig. 3.9). For these rocks assimilation of wall rock material which was hydrothermally altered under high temperature conditions cannot be excluded.

\subsubsection{Evolution of the different Alteration Types}

We propose a two stage model to explain the $\delta^{18} \mathrm{O}$ data (Fig. 3.10). Before the first stage a "normal" mantle source forms fresh magmatic rocks which show "normal" pristine $\delta^{18} \mathrm{O}$ values for the mineral phases and the whole rock. This pristine rock is influenced by a fluid under high temperature conditions. The results of this high temperature fluid overprint are lowered $\delta^{18} \mathrm{O}$ values for all mineral and the whole rock. An alternative process with the addition of hydrothermally altered crustal material is proposed for rocks with rare fresh minerals of low $\delta^{18} \mathrm{O}$. Samples of type 1 represent this first stage. These rocks are the precursors for the following second stage. The second stage is subdivided into two possible scenarios. One with a lower water/rock ratio and the other with more fluid involved. Starting with the "dry" case, the rocks modified in the first step experience a second alteration event under low temperature conditions. This second stage alteration produced higher $\delta^{18} \mathrm{O}$ values compared to the precursor. 


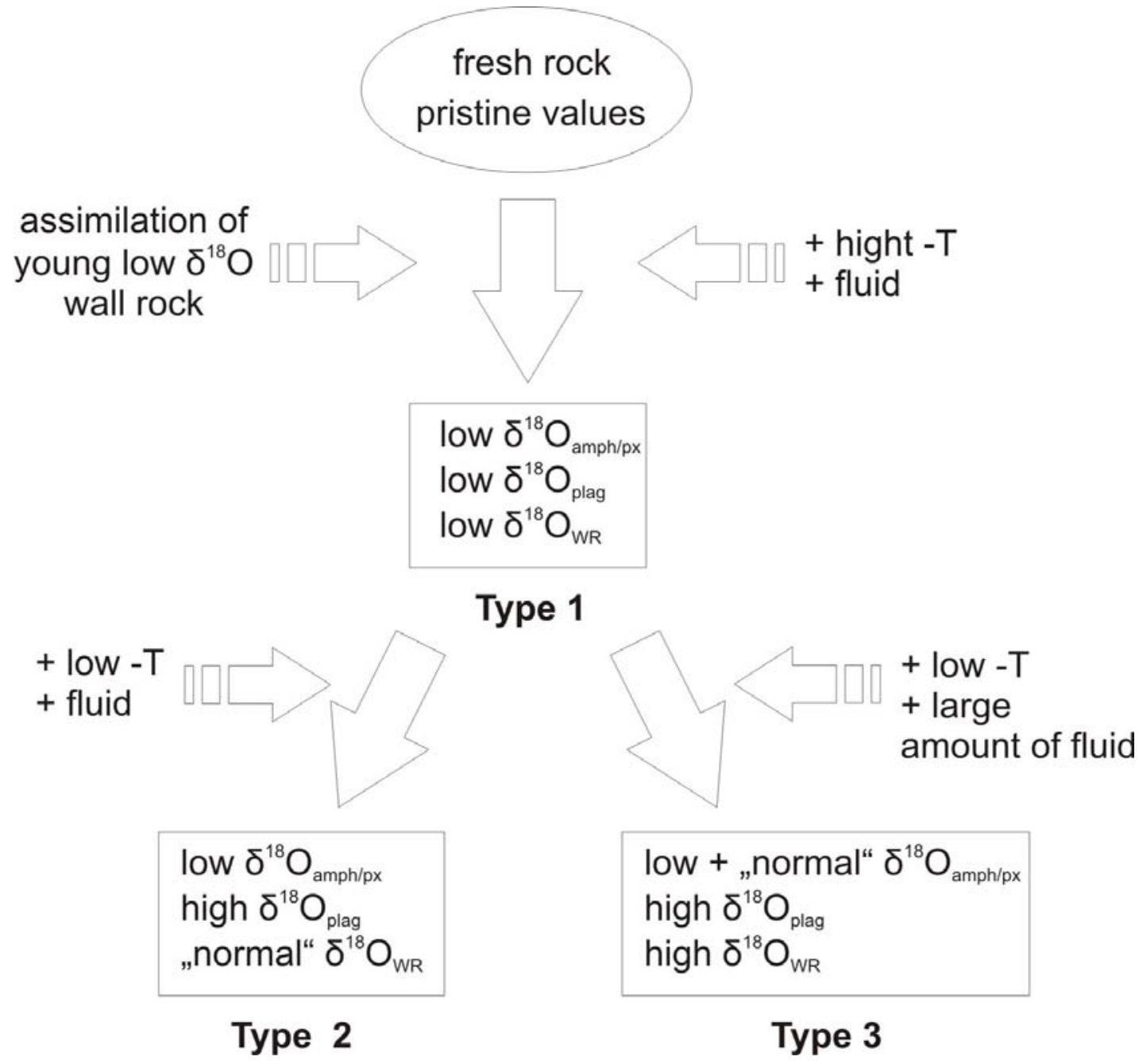

Figure 3.10. Schematic sketch showing the two stage process of the formation of the observed $\delta^{18} \mathrm{O}$ values.

As we started with low $\delta^{18} \mathrm{O}$ values in all phases, the second event leads to a visible increase of the previously depleted $\delta^{18} \mathrm{O}$ values. Depending on the stability of the different phases for alteration the weakest phase plagioclase is most easily affected. Consequently we observe for plagioclases of this group reset "normal" or even elevated $\delta^{18} \mathrm{O}$ values. For the more resistant amphiboles and pyroxenes we still see the low values formed by the first high temperature fluid alteration event. The whole rock values of these samples of type 2 show reset "normal" values, attributed to the mixture of mineral phases with different $\delta^{18} \mathrm{O}$ signatures: resistant phenocrysts show low $\delta^{18} \mathrm{O}$ values whereas the matrix and weaker phases are strongly modified. In the fluid-rich case the effects of the low temperature alteration is more intensive. The plagioclases $\delta^{18} \mathrm{O}$ values are all shifted towards high values (up to 10.2\%) and even the amphiboles and pyroxenes are shifted toward higher values and some show reset "normal" $\delta^{18} \mathrm{O}$ values. According to the more intensive alteration of matrix and 
interstitial phases whole rocks of the type 3 all show elevated $\delta^{18} \mathrm{O}$ values. All samples of type 3 are extrusive, which is consistent with a fluid-rich alteration environment.

\subsubsection{No Correlation between Elemental Composition and Alteration Proxies}

Our samples do not show any convincing correlation between water content, mineral assemblages or the $\delta^{18} \mathrm{O}$ values of the whole rock and their minerals. Oxygen isotopes and petrography argue for moderate to extensive alteration in three different environments. The trace elements however do not mirror theses distinctions. A first step to solve this problem is the examination of scaling effects. The $\delta^{18} \mathrm{O}$ mineral values and petrographic results represent small spatial scales in the size of several mineral grains. In this scale range we find mineral transformations which are clearly connected with processes of element reorganization and mobility. These alteration reactions are accompanied by changes in local mineral composition and oxygen isotopes. An example is given in Figure 3.11 for the alteration of pyroxenes and amphiboles to chlorite. $\mathrm{Ti}$ is set free during the alteration of pyroxenes and amphiboles to chlorite. Ti, which does not fit into the chlorite structure, is immobile and taken up by other phases like titanite and rutile. The same is true for Ca during the chloritization. Even though $\mathrm{Ca}$ is mobile, it is taken up locally by e.g. calcite.
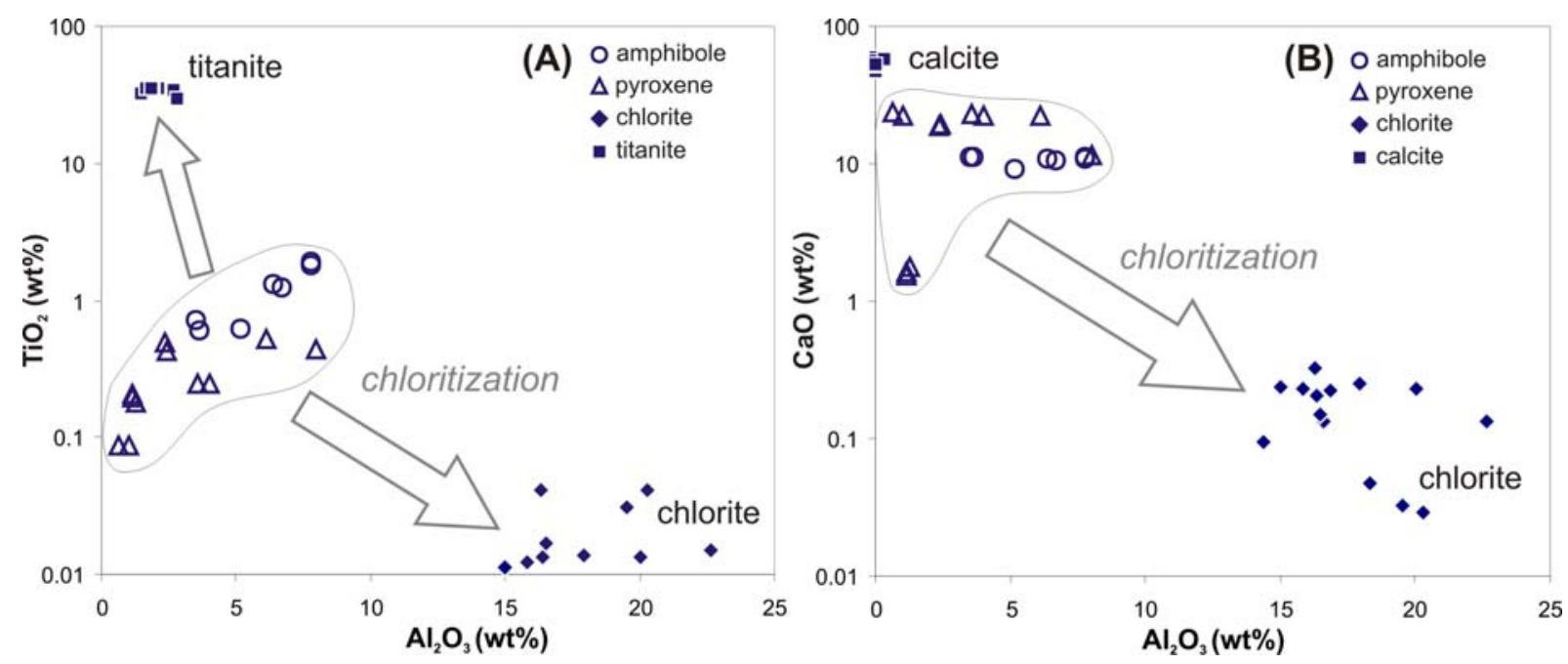

Figure 3.11. Plot of $\mathrm{Al}_{2} \mathrm{O}_{3}$ versus $(A) \mathrm{TiO}_{2}$ and $(B) \mathrm{CaO}$ in pyroxenes, amphiboles and chlorites. (A) The $\mathrm{TiO}_{2}$ loss during chloritization is compensated by formation of $\mathrm{Ti}$ rich phases like rutile and titanite. $(B)$ The released $\mathrm{CaO}$ is taken up by calcite.

Similar element reorganizations from one phase to another one are known for the sericitisation for example. For these small scale processes we conclude that there 
are diverse processes present which lead to a redistribution of elements and isotopes. This can explain the formation of secondary minerals and the differences in oxygen isotopes between altered and fresh minerals during alteration processes. However as these processes operate only on a small scale this may imply that at a hand specimen scale the effects of mineral alteration are balanced with respect to dissolution and precipitation and less chemical differences are detectable between altered and fresh bulk rocks. Element mobility at different spatial scales then is reflected in highly variable but potentially unsystematic variation of whole rock compositions.

However, this simple solution does not apply for $\delta^{18} \mathrm{O}$ values in whole rocks. These values represent the same fraction of the sample as the major and trace elements. If the above explanation applies also to the $\delta^{18} \mathrm{O}_{W R}$ values these also should be unchanged. As shown before this is not the case. In the following we give some ideas how this paradoxon could be explained. A reason is the depiction of the mobility of the major and trace elements. The CHICO provides characteristics which make it really difficult to precisely infer the mobility patterns of the particular elements. First, there is no definite fresh rock as a reference for a given altered rock type. Also, variable initial magma compositions due to different sources cannot be resolved from alteration effects. This is attributed to the high age (66 Ma) and the long activity period (ca. $25 \mathrm{Ma}$ ) of the CHICO. For alteration normalization we are therefore forced to use the least altered samples assuming that it represents the fresh rock. Second, our only tools to constrain the alteration conditions are oxygen isotopes and petrography. The composition of the fluid or the fluids involved in alteration is not known for the Chagres region, therefore the contribution of the fluid can not be considered. However a composition similar to seawater is most likely due to the submarine setting. These limitations lead to uncertainties in the identification of element mobility.

\subsubsection{Oxygen Isotopes as Tracer for multiple Alteration Events}

The most reliable and direct proxy for alteration are $\delta^{18} \mathrm{O}$ values. However the fractionation is smallest under high temperature hydrothermal conditions, but $\delta^{18} \mathrm{O}$ values of amphibole, pyroxene, plagioclase and whole rock are changed significantly. This implies intensive hydrothermal system under high temperature conditions causing the alteration early in the history of formation of the CHICO. 


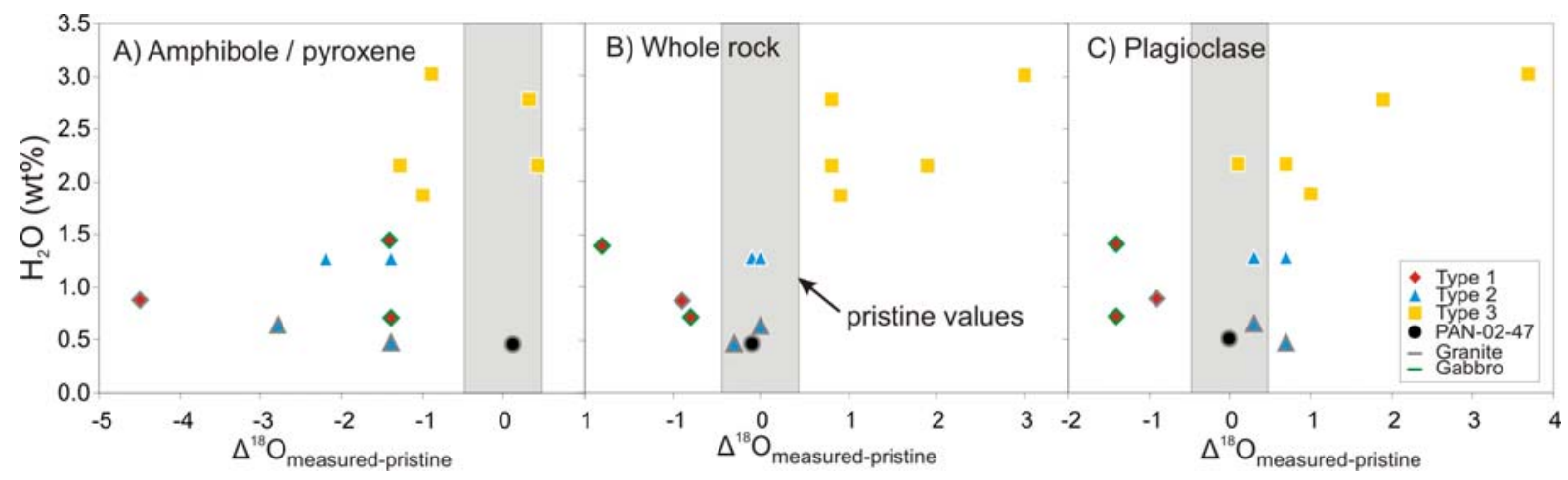

Figure 3.12. Plot of $\mathrm{H}_{2} \mathrm{O}$ versus the the $\Delta^{18} \mathrm{O}$ measured-pristine value (defined as the difference between the measured $\delta^{18} \mathrm{O}$ whole rock values and the calculated pristine $\delta^{18} \mathrm{O}$ whole rock value) for amphibole/pyroxene, whole rock and plagioclase. Note that the two alteration parameters are not correlated. Colours indicate different alteration types based on $\delta^{18} \mathrm{O}$ values.

These alteration patterns are still recorded as higher or lower $\delta^{18} \mathrm{O}$ values of the amphiboles and pyroxenes (Fig. 3.12). The plagioclases in contrast mainly show the influence of the subsequent low temperature alteration. The whole rocks represent the combination of all mineral phases, grain boundaries and matrix. Lecuyer and Reynard (1996) found that there is no major change in cations with pronounced $\delta^{18} \mathrm{O}$ depletion for fluid alteration under high temperature conditions. Hydration, $\delta^{18} \mathrm{O}$ values and element mobility increases with decreasing temperature of alteration. This implies that the depleted $\delta^{18} \mathrm{O}$ values may be reset or even reversed by the low temperature alteration event as long as fluids permeabilities are present. Apparently such resetting occurred in $\mathrm{CHICO}$ rocks but incompletely. Additionally the major and trace elements should more resemble the low temperature alteration conditions.

The alteration potential of the $\mathrm{CHICO}$ can be estimated with the help of $\delta^{18} \mathrm{O}$ values and the amount of secondary minerals per sample. Apart form three extreme samples most of them plot in a $\pm 1 \%$ field around the pristine values in $\delta^{18} \mathrm{O}_{\mathrm{WR}}$ composition (Fig. 3.12) but still show between $5-25 \%$ secondary mineral phases in thin section. Compared to mid ocean ridge and ophiolithic settings (Barrett and Friedrichsen, 1987; Gregory and Taylor, 1981) this indicates that chemical exchange and mobilization occurs on smaller length scales below the size of hand specimen. The hydrothermal system appears to be relatively inefficient compared to the hot zones of the oceanic crust and ocean island volcanoes. This might be due to differences in the state of the hydrothermal system between e.g. mid ocean ridges and the $\mathrm{CHICO}$ setting. The heat and water supply at the mid ocean ridge is rather 
continuous and steady. Therefore established fractures and pathways can be used by fluids offering a good permeability. As a consequence defined alterations zones are developed. At the $\mathrm{CHICO}$ in contrast the thermal supply is rather periodic and single rocks cycle through different thermal environments caused by multiple intrusions. This successive alteration is less intense. Beside the thermal aspect the $\mathrm{CHICO}$ provides only limited fluid pathways attributed to high eruption rates which formed vast stacks of sheet flows compared to OIB seamounts which show lower eruption rates resulting in pillows and breccias. This limitation of fluid pathways leads also to lower permeability and hence lower alteration intensity.

\subsubsection{Implications of Alteration for Interpretations of Mantle Sources}

As a surprising result, even with strong petrographic evidence for alteration and new growth of minerals, the compositional and isotopic systematics are changed relatively little. This leads creditability to the interpretation of Wegner et al. (2011) who postulated changing mantle sources based on trace element pattern and $\mathrm{Pb}-, \mathrm{Nd}-$, $\mathrm{Sr}$ - and $\mathrm{O}$ - isotopes during the time of $\mathrm{CHICO}$ formation and subsequent magmatism along the landbrige of Panama. However, sample PAN-02-47 shows that superimposed processes with contrary effects can cause apparently "normal" values, which would lead to misinterpretation in source composition constrains. However the probability that such rocks are produced in a significant amount is very low.

\subsection{CONCLUSIONS}

Based on oxygen isotopes, petrographic investigations and major and trace element composition the following conclusions for the $\mathrm{CHICO}$ can be drawn:

1. The formation of secondary alteration minerals in different amounts and composition lead to small scale element exchanges between different mineral phases.

2. Oxygen isotopes reveal three different alteration events. First all samples experienced a high temperature hydrothermal alteration. A subset of some samples (type 2 and 3) was subsequently affected by a second low temperature hydrothermal event which partly reset the changes of the former alteration. The low temperature event is subdivided into a group with low fluid/rock ratio (type 2) and high seawater/rock ratio (type 3 ). 
3. Major and trace element variations due to alteration are not correlated to oxygen isotopes, partly due to highly inhomogeneous source compositions and variable slab fluid enrichments which caused elemental variations even before alteration. In addition subsequent alteration events under changing temperature conditions and fluid rock ratios lead to contrasting element mobility. This can either intensify, smoothen out or reverse existing element patterns.

4. Weathering effects can mostly be excluded for major and trace elements. For oxygen isotopes the effects of low temperature alteration would be intensified.

5. The alteration potential of the $\mathrm{CHICO}$ rocks is less pronounced than the one of mid ocean ridges and ocean island volcanoes. Therefore even massive submarine volcanism of the CHICO type would not lead to extensive exchanges between seawater and magmatic rocks.

6. Taking the Chagres igneous complex as an example it is shown that even with strong petrographic evidence for alteration and new growth of minerals, the compositional and isotopic systematics may change relatively little. This leads creditability to the interpretation of changing mantle sources based on trace element pattern and $\mathrm{Pb}-, \mathrm{Nd}-, \mathrm{Sr}$ - and $\mathrm{O}$ - isotopes

For further investigations, alteration studies are easier in regions of homogeneous source composition and without subduction fluid addition. For more detailed results of the $\mathrm{CHICO}$ the knowledge about the composition of the alteration fluid and the fresh rock would facilitate the investigations and lead to real numbers for element fluxes. Additionally more mineral phases like quartz and the secondary phases like chlorite, epidot and prehnite should be measured for oxygen isotopes to better constrain the alteration trends by complete mass balance.

\subsection{REFERENCES}

Abratis, M., and Worner, G., 2001, Ridge collision, slab-window formation, and the flux of Pacific asthenosphere into the Caribbean realm: Geology, v. 29, no. 2, p. 127-130.

Alt, J. C., and Teagle, D. A. H., 2003, Hydrothermal alteration of upper oceanic crust formed at a fast-spreading ridge: mineral, chemical, and isotopic evidence from ODP Site 801: Chemical Geology, v. 201, no. 3-4, p. 191-211.

Alt, J. C., Teagle, D.A.H., Laverne, C., Vanko, D.A., Bach, W., Honnorez, J., Becker, K., Ayadi, M., and Pezard, P.A., 1996., Ridge-flank alteration of upper ocean crust in the eastern Pacific: synthesis of results for volcanic rocks of Holes 
504B and 896A, in Alt, J. C., Kinoshita, H., Stokking, L.B., and Michael, P.J. (Eds.), ed., Proc. ODP, Sci. Results, 148:: College Station.

Bach, W., Alt, J. C., Niu, Y., Humphris, S. E., Erzinger, J., and Dick, H. J. B., 2001, The geochemical consequences of late-stage low-grade alteration of lower ocean crust at the SW Indian Ridge: results from ODP Hole 735B (Leg 176): Geochimica Et Cosmochimica Acta, v. 65, no. 19, p. 3267-3287.

Barrett, T. J., and H., F., 1987, Oxygen-isotopic composition of basalts from young spreading axes in the eastern Pacific: Canadian Journal of Earth Sciences, v. 24 , no. 11 , p. 2105-2117.

Bednarz, U., and Schmincke, H. U., 1989, Mass-Transfer during sub-seaflor alteration of the uper Troodos crust (Cyprus): Contributions to Mineralogy and Petrology, v. 102, no. 1, p. 93-101.

Bindeman, I. N., Eiler, J. M., Yogodzinski, G. M., Tatsumi, Y., Stern, C. R., Grove, T. L., Portnyagin, M., Hoernle, K., and Danyushevsky, L. V., 2005, Oxygen isotope evidence for slab melting in modem and ancient subduction zones: Earth and Planetary Science Letters, v. 235, no. 3-4, p. 480-496.

Bindeman, I. N., Ponomareva, V. V., Bailey, J. C., and Valley, J. W., 2004, Volcanic arc of Kamchatka: a province with high-[delta]180 magma sources and largescale 180/160 depletion of the upper crust: Geochimica et Cosmochimica Acta, v. 68 , no. 4, p. 841-865.

Buchs, D. M., Arculus, R. J., Baumgartner, P. O., Baumgartner-Mora, C., and Ulianov, A., Late Cretaceous arc development on the SW margin of the Caribbean Plate: Insights from the Golfito, Costa Rica, and Azuero, Panama, complexes: Geochemistry Geophysics Geosystems, v. 11.

Chen, J. H., Wasserburg, G. J., Vondamm, K. L., and Edmond, J. M., 1986, The UTh- $\mathrm{Pb}$ systematics in hot-springs on the East Pacific Rise at $21^{\circ} \mathrm{N}$ and Guaymas-basin: Geochimica et Cosmochimica Acta, v. 50, no. 11, p. 24672479.

Christidis, G. E., 1998, Comparative study of the mobility of major and trace elements during alteration of an andesite and a rhyolite to bentonite, in the Islands of Milos and Kimolos, Aegean, Greece: Clays and Clay Minerals, v. 46, no. 4, p. 379-399.

Coates, A. G., Jackson, J. B. C., Collins, L. S., Cronin, T. M., Dowsett, H. J., Bybell, L. M., Jung, P., and Obando, J. A., 1992, Closure of the Isthmus of Panama: The near-shore marine record of Costa Rica and western Panama: Geological Society of America Bulletin, v. 104, no. 7, p. 814-828.

Collins, L. S., Coates, A. G., Berggren, W. A., Aubry, M.-P., and Zhang, J., 1996, The late Miocene Panama isthmian strait: Geology, v. 24, no. 8, p. 687-690.

de Boer, J., Drummond, M., Bordelon MJ, Defant MJ, Bellon H, and RC, M., 1995, Cenozoic magmatic phases of the Costa Rican island arc (Cordillera de Talamanca), in Mann, P., ed., Geologic and Tectonic Development of the Caribbean Plate Boundary in Southern Central America: Boulder, Colorado, Geological Society of America, p. 35-55.

de Boer, J. Z., Defant, M. J., Stewart, R. H., and Bellon, H., 1991, Evidence for active subduction below western Panama: Geology, v. 19, no. 6, p. 649-652. 
Defant, M., Clark, L., Stewart, R., Drummond, M., de Boer, J., Maury, R., Bellon, H., Jackson, T., and Restrepo, J., 1991a, Andesite and dacite genesis via contrasting processes: the geology and geochemistry of El Valle Volcano, Panama: Contributions to Mineralogy and Petrology, v. 106, no. 3, p. 309-324.

Defant, M. J., Richerson, P. M., De Boer, J. Z., Stewart, R. H., Maury, R. C., Bellon, H., Drummond, M. S., Feigenson, M. D., and Jackson, T. E., 1991b, Dacite Genesis via both Slab Melting and Differentiation: Petrogenesis of La Yeguada Volcanic Complex, Panama: Journal of Petrology, v. 32, no. 6, p. 1101-1142.

Eiler, J. M., Carr, M. J., Reagan, M., and Stolper, E., 2005, Oxygen isotope constraints on the sources of Central American arc lavas: Geochemistry Geophysics Geosystems, v. 6.

Eiler, J. M., Farley, K. A., Valley, J. W., Hauri, E., Craig, H., Hart, S. R., and Stolper, E. M., 1997, Oxygen isotope variations in ocean island basalt phenocrysts: Geochimica et Cosmochimica Acta, v. 61, no. 11, p. 2281-2293.

Eiler, J. M., Farley, K. A., Valley, J. W., Hofmann, A. W., and Stolper, E. M., 1996, Oxygen isotope constraints on the sources of Hawaiian volcanism: Earth and Planetary Science Letters, v. 144, no. 3-4, p. 453-467.

Eiler, J. M., Grönvold, K., and Kitchen, N., 2000, Oxygen isotope evidence for the origin of chemical variations in lavas from Theistareykir volcano in Iceland's northern volcanic zone: Earth and Planetary Science Letters, v. 184, no. 1, p. 269-286.

Garcia, M. O., Ito, E., Eiler, J. M., and Pietruszka, A. J., 1998, Crustal Contamination of Kilauea Volcano Magmas Revealed by Oxygen Isotope Analyses of Glass and Olivine from Puu Oo Eruption Lavas: Journal of Petrology, v. 39, no. 5, p. 803-817.

Gregory, R. T., and Taylor, H. P., 1981, An oxygen isotope profile in a section od cretaceous oceanis-crust, Samil orphiolite, Oman- Evidence for delta-18-O buffering of the oceans deep (less tha $5 \mathrm{~km}$ ) seawater-hydrothermal circulation at mid-ocean ridges: Journal of Geophysical Research, v. 86, no. NB4, p. 2737-2755.

Harmon, R. S., and Gerbe, M. C., 1992, The 1982-83 eruption at Galunggung Volcano, Java (Indonesia): Oxygen isotope geochemistry of a chemically zoned magma chamber: Journal of Petrology, v. 33, no. 3, p. 585-609.

Hauff, F., Hoernle, K., Schmincke, H. U., and Werner, R., 1997, A Mid Cretaceous origin for the Galápagos hotspot: volcanological, petrological and geochemical evidence from Costa Rican oceanic crustal segments: Geologische Rundschau, v. 86 , no. 1, p. 141-155.

Hauff, F., Hoernle, K., van den Bogaard, P., Alvarado, G., and Garbe-Schönberg, D., 2000, Age and geochemistry of basaltic complexes in western Costa Rica: Contributions to the geotectonic evolution of Central America: Geochemistry Geophysics Geosystems, v. 1, no. 5.

Hoefs, J., 2009, Stable Isotope Geochemistry: Heidelberg, Berlin, New York, Springer, 308 p.

Hoernle, K., Hauff, F., and van den Bogaard, P., 2004, 70 m.y. history (139-69 Ma) for the Caribbean large igneous province: Geology, v. 32, no. 8, p. 697-700. 
Hoernle, K., van den Bogaard, P., Werner, R., Lissinna, B., Hauff, F., Alvarado, G., and Garbe-Schonberg, D., 2002, Missing history (16-71 Ma) of the Galapagos hotspot: Implications for the tectonic and biological evolution of the Americas: Geology, v. 30, no. 9, p. 795-798.

James, R. H., Allen, D. E., and Seyfried, W. E., 2003, An experimental study of alteration of oceanic crust and terrigenous sediments at moderate temperatures (51 to 350 degrees $\mathrm{C}$ ): Insights as to chemical processes in near-shore ridge-flank hydrothermal systems: Geochimica Et Cosmochimica Acta, v. 67, no. 4, p. 681-691.

Johnston, S. T., and Thorkelson, D. J., 1997, Cocos-Nazca slab window beneath Central America: Earth and Planetary Science Letters, v. 146, no. 3-4, p. 465474.

Le Maitre, R. W., Bateman, P., Dudek, A., Keller, J., Lemeyre J., Le Bas, M., Sabine, P., Schmid, R., Sorensen, H., Streckeisen, A., Wooley, A., and Zanettin, B., 1989, A classification of igneous rocks and glossary of terms: Oxford, Blackwell Publishing, 193 p.

Lecuyer, C., and Reynard, B., 1996, High-temperature alteration of oceanic gabbros by seawater (Hess Deep, Ocean Drilling Program Leg 147): Evidence from oxygen isotopes and elemental fluxes: Journal of Geophysical Research-Solid Earth, v. 101, no. B7, p. 15883-15897.

Lonsdale, P., and Klitgord, K. D., 1978, Structure and tectonic history of the eastern Panama Basin: Geological Society of America Bulletin, v. 89, no. 7, p. 981999.

Macpherson, C. G., Hiltonb, D. R., Matteya, D. P., and Sintonc, J. M., 2000, Evidence for an 180-depleted mantle plume from contrasting 180/160 ratios of backarc lavas from the Manus Basin and Mariana Trough Earth and Planetary Science Letters, v. 176, no. 2, p. 171-183

Mann, P., and Kolarsky, R., 1995, East Panama deformed belt; structure, age, and neotectonic significance in Mann, P., ed., Geologic and Tectonic Development of the Caribbean Plate Boundary in Southern Central America: Boulder, Colorado, Geological Society of America, p. 111-130.

Matsuhisa, Y., 1979, Oxygen isotopic compositions of volcanic rocks from the east Japan island arcs and their bearing on petrogenesis: Journal of Volcanology and Geothermal Research, v. 5, no. 3-4, p. 271-296.

McCulloch, M. T., Gregory, R. T., Wasserburg, G. J., and Taylor, H. P., 1980, Neodymium, Strontium and oxygen isotopic study of the Cretaceous Samail ophiolite and implications for teh petrogenesis and seawater-hydrothermal alteration of the oceanic-crust: Earth and Planetary Science Letters, v. 46, no. 2, p. 201-211.

Michard, A., and Albarede, F., 1985, Hydrothermal uranium uptake at ridge crests: Nature, v. 317, no. 6034 , p. 244-246.

Mottl, M. J., and Holland, H. D., 1978, Chemical exchange during hydrothermal alteration of basalt by seawater. 1. Experimental results for major and minor components of seawater: Geochimica et Cosmochimica Acta, v. 42, no. 8, p. 1103-1115. 
Muehlenbachs, K., and Byerly, G., 1982, O-18-enrichement of silicic magmas caused by crystal fractionation at the Galapagos spreading center: Contributions to Mineralogy and Petrology, v. 79, no. 1, p. 76-79.

Muehlenbachs, K., and Clayton, R. N., 1972, Oxygen Isotope Studies of Fresh and Weathered Submarine Basalts: Canadian Journal of Earth Sciences v. 9, no. 2, p. $172-184$.

Nakamura, K., Kato, Y., Tamaki, K., and Ishii, T., 2007, Geochemistry of hydrothermally altered basaltic rocks from the Southwest Indian Ridge near the Rodriguez Triple Junction: Marine Geology, v. 239, no. 3-4, p. 125-141.

Pindell, J., Kennan, L., Stanek, K. P., Maresch, M. W., Draper G., 2006, Foundations of Gulf of Mexico and Caribbean evolution: eight controversies resolved: Geological Acta, v. 4, p. 303-341.

Rickwood, P. C., 1989, Boundary lines within petrologic diagrams which use oxides of major and minor elements: Lithos, v. 22, no. 4, p. 247-263.

Schiffman, P., and Staudigel, H., 1994, Hydrothermal alteration of a seamount complex on La Palma, Canary Islands: Implications for metamorphism in accreted terranes: Geology, v. 22, no. 2, p. 151-154.

Schiffman, P., and Staudigel, H, 1995, The smectite to chlorite transition in a fossil seamount hydrothermal system; the basement complex of La Palma, Canary Islands.: Journal of Metamorphic Geology, v. 13, no. 4, p. 487-498.

Seyfried, W. E., Chen, X., and Chan, L. H., 1998, Trace element mobility and lithium isotope exchange during hydrothermal alteration of seafloor weathered basalt: An experimental study at 350 degrees C, 500 bars: Geochimica Et Cosmochimica Acta, v. 62, no. 6, p. 949-960.

Seyfried, W. E., and Mottl, M. J., 1982, Hydrothermal alteration of basalt by seawater under seawater-dominated conditions: Geochimica Et Cosmochimica Acta, v. 46 , no. 6 , p. $985-1002$.

Staudigel, H., Plank, T., White, W. M., and Schmincke, H., 1996, Geochemical fluxes during seafloor alteration of the upper oceanic crust: DSDP Sites 417 and 418, in Bebout, K., ed., Subduction From Top to Bottom, Geophysical Monograph, p. 19-38.

Striepe, S., 2007, Elementmobilität während der tropischen Verwitterung eines Gabbros; Panama [Beachelor thesis thesis]: Universität Göttingen, 92 p.

Sun, S. S., and McDonough, W. F., 1989, Chemical and isotopic systematics of oceanic basalts: implications for mantle composition and processes: Geological Society, London, Special Publications, v. 42, no. 1, p. 313-345.

Taylor, H. P., 1980, The effects of assimilation of country rocks by magmas on $18 \mathrm{O} / 16 \mathrm{O}$ and $87 \mathrm{Sr} / 86 \mathrm{Sr}$ systematics in igneous rocks: Earth and Planetary Science Letters, v. 47, no. 2, p. 243-254.

Thirlwall, M. F., Jenkins, C., Vroon, P. Z., and Mattey, D. P., 1997, Crustal interaction during construction of ocean islands: $\mathrm{Pb}-\mathrm{Sr}-\mathrm{Nd}-\mathrm{O}$ isotope geochemistry of the shield basalts of Gran Canaria, Canary Islands: Chemical Geology, v. 135, no. 3-4, p. 233-262.

Wegner, W., Wörner, G., Harmon, R. S., and Jicha, B. R., 2011, Magmatic history and evolution of the Central American Land Bridge in Panama since 
Cretaceous times: Geological Society of America Bulletin, v. 123, no. 3-4, p. 703-724.

Wörner, G., Harmon, R., Hartmann, G., and Simon, K., 2005, Geology and Geochemistry of Igneous Rocks in the Chagres River Basin, in RS, H., ed., The Chagres Basin, Multidisciplinary Profile of a Tropical Watershed: Water Science and Technology Library, Springer, p. 65-82.

Wörner, G., Harmon, R. S., and Wegner, W., 2009, Geochemical evolution of igneous rock and changing Magma Sources during the Evolution and Closure of the Central American Landbridge, in S. M. Kay, V. A. Ramos, and Dickinson, W. R., eds., GSA Memoir, Backbone of the Americas: Shallow Subduction, Plateau Uplift, and Ridge and Terrane Collision: Boulder, Colorado, p. 183-196. 


\section{Chatiser}

Geochemical evolution of igneous rock and changing

magma sources during the formation and closure of the

Central American land bridge of Panama

Gerhard Wörner ${ }^{1}$, Russell S. Harmon ${ }^{2}$, and Wencke Wegner ${ }^{1}$

${ }^{1}$ Abt. Geochemie, GZG, Universität Göttingen, Goldschmidtstr. 1,

37077 Göttingen, Germany

${ }^{2}$ Army Research Office, U.S. Army Research Laboratory, P.O. Box 12211,

Research Triangle Park, NC 27709, USA

The Geological Society of America Memoir 204, pages 183-194

2009 


\subsection{ABSTRACT}

The geological development of Panama's isthmus resulted from intermittent magmatism and oceanic plate interactions over approximately the past 100 m.y. Geochemical data from $\sim 300$ volcanic and intrusive rocks sampled along the Cordillera de Panama document this evolution and are used to place it within a tectonic framework. Three distinct trace element signatures are recognized in the oldest basement rocks: (1) oceanic basement of the Caribbean Large Igneous Province (CLIP-basement) that display flat trace element patterns, (2) CLIP terranes show enriched ocean-island basalt (OIB) signatures, and (3) CLIP rocks exhibit arc signatures.

The Chagres Igneous Complex represents the oldest evidence of arc magmatism in Panama. These rocks are tholeiitic, with enriched but highly variable fluid-mobile element (Cs, Ba, Rb, K, Sr) abundances. Ratios of these large ion lithophile elements (LILEs) to immobile trace elements (e.g., $\mathrm{Nb}$, Ta, middle and heavy rare earth elements) have a typical, but variably depleted, arc-type character that was produced by subduction below the CLIP oceanic plateau. These early arc rocks likely comprise much of the upper crust of the Cordillera de Panama and indicate that by $66 \mathrm{Ma}$ the mantle wedge beneath Panama was chemically distinct (i.e., more depleted) and highly variable in composition compared to the Galapagos mantle material from which earlier CLIP magmas were derived.

Younger Miocene andesites were erupted across the Cordillera de Panama from 20 to $5 \mathrm{Ma}$ and display relatively uniform trace-element patterns. High field strength elements (HFSEs) increase from a tholeiitic to medium-K arc compositions. The change in mantle sources from CLIP basement to arc magmas indicates that enriched sub-CLIP (i.e., plume) mantle material was no longer present in the mantle wedge at the time that subduction magmatism commenced in the area. Instead, a large spectrum of mantle compositions was present at the onset of arc magmatism, onto which the arc fluid signature was imprinted. Arc maturation led to a more homogeneous mantle wedge, which became progressively less depleted due to mixing or entrainment of less-depleted back-arc mantle through time.

Normal arc magmatism in the Cordillera de Panama terminated around 5 Ma due to the collision of a series of aseismic ridges with the developing and emergent Panama landmass. Younger heavy rare earth element-depleted magmas (younger than $2 \mathrm{Ma}$ ) 
which still carry a strong arc geochemical signature, were probably produced by oceanic-ridge melting after their collision.

\subsection{INTRODUCTION AND GEOLOGICAL SETTING}

The western part of the Central American land bridge between the Santa Elena transform fault in northern Costa Rica, which is the boundary with the continental Chortis terrane of northern Central America, and the Atrato fault zone in northern Colombia, which is a westward extension of the South Caribbean fault, is characterized by a series of mafic complexes (Fig. 4.1) that form the foundation of the Central American land bridge. These mafic terranes represent the major constructional elements of the Central American crust of Costa Rica and Panama. Similar terranes are known from Colombia and northern Ecuador (Goossens et al., 1977; Reynaud et al., 1999). Goossens et al. (1977) first noted their age range, from the Cretaceous to the Eocene and described their distribution from northern Costa Rica to the northern Colombian Andes. Based on similar lithology and common tholeiitic character Goossens et al. (1977) also proposed their correlation and common origin as accreted oceanic terrains. More recently, Hauff et al. (2000) and Hoernle et al. $(2002,2004)$ suggested the term Caribbean Large Igneous Province (CLIP) for this region and linked these CLIP rocks to the Galapagos plume and the thickened oceanic crust of the Caribbean Plate. They interpreted these mafic terranes as a series of aseismic ridges and ocean islands from the Galapagos plume, equivalents of which can be observed as aseismic ridges on the Nazca Plate (Fig. 4.1). These authors also confirmed the Cretaceous to Tertiary age for these terranes first proposed by Goossens et al (1977) based on more precise Ar-Ar dating (139 and $50 \mathrm{Ma}$, see recent compilation by Hoernle and Hauff, 2007). Still, the origin of these terranes and the Caribbean Plate remain a matter of debate and involves a complex and controversial tectonic history (Pindell et al., 2006 and reference therein) for the Caribbean plate with which they are associated. Hypothetical origins that have been proposed include: (1) A change from westward-dipping subduction of the Farallon plate to an eastward-facing Caribbean arc system in Aptian time (Pindell et al., 2005); (2) Formation of the Caribbean Large Igneous Province (CLIP), either subsequent to the development of the Galapagos plume as a consequence of subduction of the proto-Caribbean spreading center and formation of a slab window (Pindell et al., 2006), or by successive accretion of oceanic ridges over some $70 \mathrm{~m}$. 
y. (Hoernle et al., 2004); (3) Northwestward movement of the Caribbean plate between North and South America with southwest subduction of the proto-Caribbean oceanic crust and associated magmatism in the Greater Antillean arc; (4) Consumption of the Proto-Caribbean oceanic crust by trench-trench collision with South America during Late Cretaceous-Paleocene time (i.e., 60-70 Ma; Pindell et al., 2006); and (5) Establishment of a more recent northeastward-verging subduction zone, terrane accretion, and arc magmatism that developed at the western margin of the modern Caribbean plate (Mann and Kolarsky, 1995; de Boer et al., 1988; Pindell and Barret, 1990).

Subaerial volcanic rocks in Costa Rica and Panama were produced by a younger island arc system that evolved from the Oligocene to present from a tholeiitic to a more mature arc calc-alkaline character (Alvarado et al., 1992; de Boer et al., 1995; Abratis and Wörner, 2001). Presently-active arc volcanism in Costa Rica, westernmost Panama, and northern Colombia is associated with the northwestward (northeastward) subduction of the Cocos and. Nazca Plates respectively (Fig. 4.1).

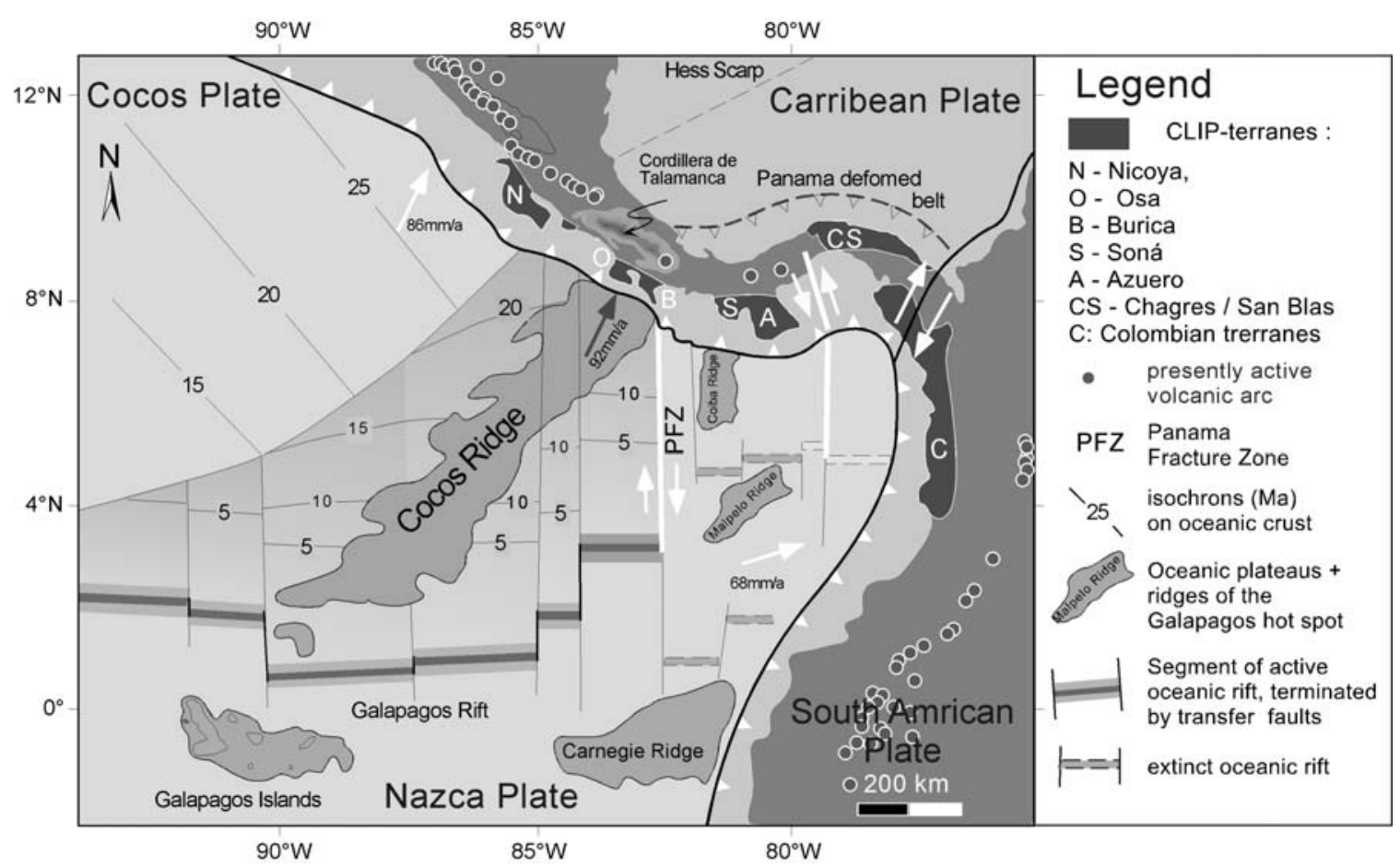

Figure 4.1. Plate-tectonic setting of the Central American land bridge following Meschede and Barckhausen (2001); accreted mafic complexes from Goossens et al. (1977). CLIP - Caribbean large igneous province. 
Two volcanic gaps presently exist in the region, the first where the Cocos Ridge collided with the arc in southern Costa Rica, and the second in central and eastern Panama where plate convergence has been accommodated since the mid-Miocene time by movement along the N-S trending Panama Fracture Zone and in the Panama deformed belt of the Caribbean plate (Fig. 4.1). As a consequence, the convergent plate boundary in central and eastern Panama has locked, arc volcanism has ceased, and related northward displacement of Panama has been accommodated by strike-slip motion, oroclinal bending, and resulting E-W-extension (Fig. 4.1, Escalante, 1990). The result of this complex tectonic situation was a zone of low topography in central Panama were the final closure of the land bridge occurred some 3-2 m.y. ago (Collins et al., 1996; Haug et al. 1998; Coates et al., 2000).

The Panama Canal was built in this region, between mountainous landscapes generated by the compressional regime to the west and transpressional deformation in eastern Panama and northern Colombia.

Based on data from the literature combined with our new analyses, this paper documents changing magma compositions over the past 66 m.y. in western-central Panama and traces their changing mantle sources through this time interval. These changes reflect the crustal growth and arc maturation that, together with the juvenile magmatic addition to the upper plate, led to the final closure of the land bridge and fostered its consolidation.

\subsection{ANALYTICAL METHODS}

Some 300 samples of Late Cretaceous- to Quaternary- age igneous rocks were collected at 207 localities along the Cordillera de Panama (Fig. 4.2). Representative samples of between 1 and $3 \mathrm{~kg}$ of the most unaltered rock present at each location were selected for X- ray fluorescence (XRF) spectroscopy and inductive couple plasma-mass spectrometry (ICP-MS) determination of whole-rock chemical composition. For some of the more altered samples, secondary veins were removed by handpicking after initial crushing. About $100 \mathrm{~g}$ of this sample material was then ground to powder $(<65 \mu \mathrm{m})$ in an agate mill.

Major- and minor- element ( $\mathrm{Si}, \mathrm{Ti}, \mathrm{Al}, \mathrm{Fe}, \mathrm{Mn}, \mathrm{Mg}, \mathrm{Ca}, \mathrm{Na}, \mathrm{K}, \mathrm{P}$ ) abundances were measured by XRF on fused glass discs. Measurements were undertaken on a Philips PW 1480 XRF spectrometer. Based on multiple measurements of internal and international reference material, the analytical error for both major and minor 
elements is $\pm 0.4-1.8 \%$. Trace element (Nb, Ta, Be, Cs, Cu, Hf, Li, Y, Pb, Rb, TI, Th, $U$ and rare earth element [REE]) abundances were measured by ICP-MS. Sample were digested in pressurized Teflon vessels by dissolving a $100 \mathrm{mg}$ sample in a solution of $3 \mathrm{ml} \mathrm{HF}$ and $2 \mathrm{ml} \mathrm{HNO}_{3}$. Samples were then repeatedly dried down and redissolved in a mixture of $1 \mathrm{ml} \mathrm{HClO}_{4}$ and $1 \mathrm{ml} \mathrm{HF}$. In a final step, an internal standard containing $20 \mathrm{ppb} \mathrm{Rh}, \mathrm{Re}$, and In was mixed into a mixture of $750 \mu \mathrm{HClO}_{4}$, $500 \mu \mathrm{HF}$, and $2 \mathrm{ml} \mathrm{HNO}_{3}$, and the final solution was diluted with deionised water to a volume of $100 \mathrm{ml}$. A blank solution and standards were prepared for each batch of 18 samples. The spiked solution was analyzed using a FISONS VG PQ STE instrument. Standard JA2 was analyzed every 11 samples. The $\pm 2 \sigma$ error of the method is estimated to be $<20 \%$ for $\mathrm{Nb}$ and $\mathrm{Ta}$, $<10 \%$ for $\mathrm{Be}, \mathrm{Cs}, \mathrm{Cu}, \mathrm{Hf}, \mathrm{Li}, \mathrm{Y}, \mathrm{Pb}$, $\mathrm{Rb}, \mathrm{TI}, \mathrm{Th}$ and $\mathrm{U}$ and $\sim 5 \%$ for the rare earth elements (REEs).

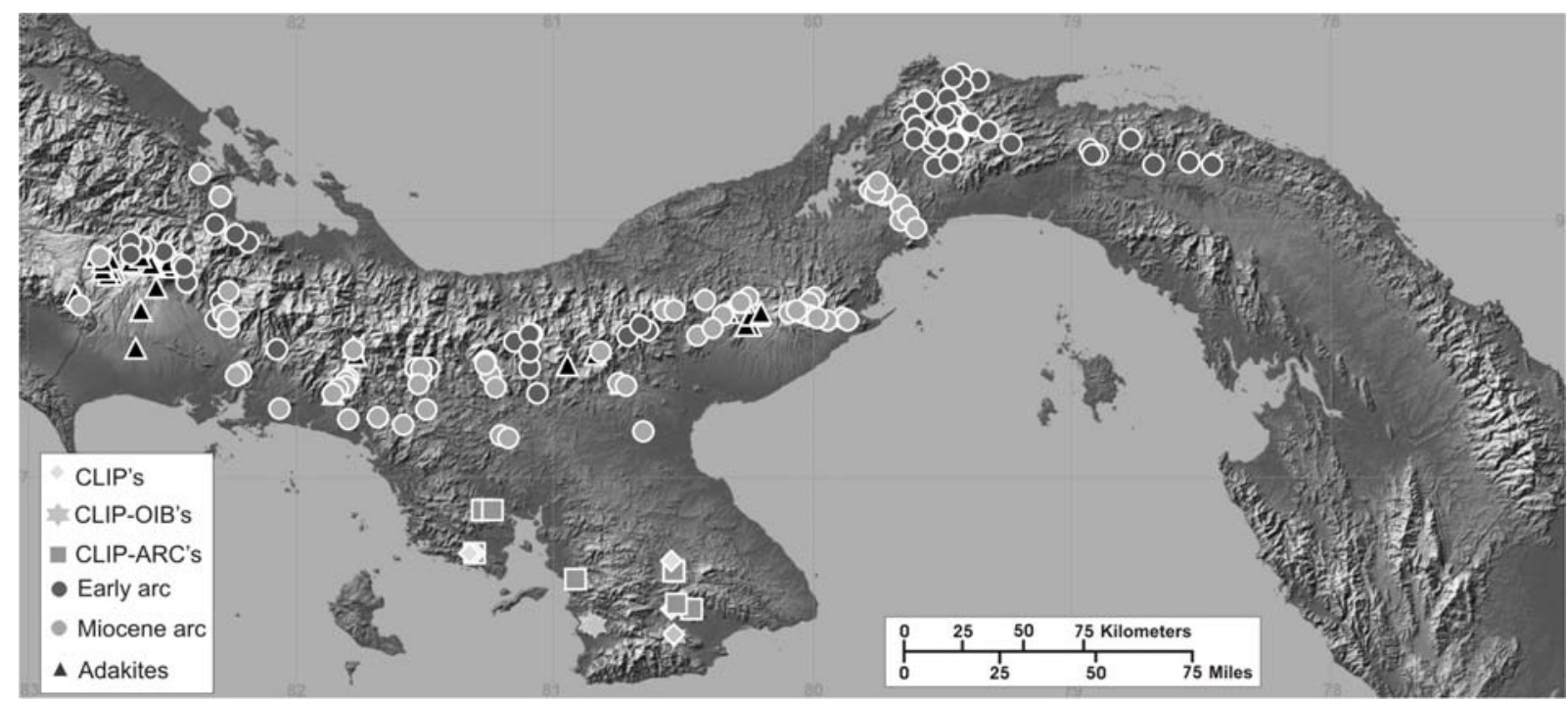

Figure 4.2. Map of Panama showing the sample locations of this study. The different symbols refer to the tectonic association of each sample. CLIP - Caribbean large igneous province; OIB - ocean-island basalt; $A R C$ - arc rocks of variable age.

\subsection{RESULTS}

Geochemical analyses of representative samples are provided in Table 4.1, where all data have been normalized to volatile-free compositions and total Fe is reported as $\mathrm{Fe}^{2+} \mathrm{O}$. A complete data set of major and trace element analyses is in the GSA Data Repository, or, alternatively, a full data table is provided in the electronic appendix. 
Table 4.1. Major- and trace-element composition of representative sample.

\begin{tabular}{|c|c|c|c|c|c|c|c|c|c|c|}
\hline \multirow[b]{2}{*}{ Sample } & \multicolumn{5}{|c|}{ Group 1: CLIP oceanic basement } & \multicolumn{5}{|c|}{ Group 2: CLIP-OIB } \\
\hline & $\begin{array}{l}\text { PAN- } \\
06-197\end{array}$ & $\begin{array}{l}\text { PAN- } \\
06-198\end{array}$ & $\begin{array}{c}\text { PAN- } \\
05-029\end{array}$ & $\begin{array}{c}\text { PAN- } \\
05-018\end{array}$ & $\begin{array}{c}\text { PAN- } \\
05-009\end{array}$ & $\begin{array}{l}\text { PAN- } \\
05-019\end{array}$ & $\begin{array}{l}\text { PAN- } \\
05-028\end{array}$ & $\begin{array}{c}\text { PAN- } \\
05-020\end{array}$ & $\begin{array}{l}\text { PAN- } \\
05-011\end{array}$ & $\begin{array}{l}\text { PAN- } \\
05-026\end{array}$ \\
\hline Region & Sona & Sona & Azuero & Azuero & Azuero & Azuero & Azuero & Azuero & Azuero & Azuero \\
\hline EASTING & 459472 & 460897 & 503618 & 538893 & 546883 & 510795 & 509629 & 510795 & 539597 & 510795 \\
\hline NORTHING & 853859 & 853719 & 842217 & 831487 & 831171 & 824126 & 824335 & 824126 & 820923 & 824126 \\
\hline Lithology & basalt & basalt & basalt & basalt & basalt & basalt & basalt & basalt & basalt & basalt \\
\hline $\mathrm{SiO}_{2}$ & 47.9 & 48.2 & 47.9 & 48.7 & 48.4 & 39.9 & 42.0 & 45.4 & 48.3 & 46.1 \\
\hline $\mathrm{TiO}_{2}$ & 1.02 & 1.08 & 2.02 & 1.30 & 1.99 & 0.76 & 1.27 & 3.46 & 2.80 & 3.05 \\
\hline $\mathrm{Al}_{2} \mathrm{O}_{3}$ & 14.37 & 14.17 & 14.40 & 14.10 & 14.90 & 4.20 & 6.30 & 13.40 & 13.40 & 13.80 \\
\hline $\mathrm{Fe}_{2} \mathrm{O}_{3}$ & 10.44 & 11.31 & 13.18 & 12.73 & 13.36 & 12.66 & 13.85 & 13.13 & 11.46 & 11.76 \\
\hline $\mathrm{MnO}$ & 0.18 & 0.18 & 0.25 & 0.18 & 0.22 & 0.17 & 0.17 & 0.17 & 0.15 & 0.16 \\
\hline $\mathrm{MgO}$ & 8.34 & 8.32 & 6.83 & 7.71 & 4.70 & 30.91 & 26.30 & 5.74 & 6.80 & 5.53 \\
\hline $\mathrm{CaO}$ & 13.24 & 11.07 & 10.64 & 12.47 & 8.19 & 5.09 & 5.08 & 8.79 & 9.38 & 7.86 \\
\hline $\mathrm{Na}_{2} \mathrm{O}$ & 1.93 & 3.05 & 3.22 & 1.89 & 4.68 & 0.01 & 0.74 & 3.54 & 3.82 & 3.04 \\
\hline $\mathrm{K}_{2} \mathrm{O}$ & 0.07 & 0.11 & 0.17 & 0.07 & 0.17 & 0.02 & 0.16 & 1.24 & 0.64 & 0.17 \\
\hline $\mathrm{P}_{2} \mathrm{O}_{5}$ & 0.077 & 0.088 & 0.194 & 0.101 & 0.215 & 0.079 & 0.134 & 0.383 & 0.273 & 0.383 \\
\hline Total & 97.57 & 97.59 & 98.80 & 99.25 & 96.82 & 93.80 & 96.01 & 95.25 & 97.03 & 91.84 \\
\hline Sc & 64 & 57 & 53 & 51 & 43 & 15 & 19 & 30 & 35 & 35 \\
\hline V & 333 & 327 & 357 & 317 & 383 & 96 & 145 & 299 & 287 & 304 \\
\hline Co & 42 & 45 & 45 & 49 & 41 & 109 & 105 & 43 & 40 & 44 \\
\hline $\mathrm{Ni}$ & 97 & 103 & 73 & 90 & 28 & 1463 & 1155 & 57 & 98 & 83 \\
\hline $\mathrm{Zn}$ & 70 & 76 & 132 & 100 & 124 & 88 & 117 & 134 & 116 & 120 \\
\hline $\mathrm{Rb}$ & 2.23 & 2.4 & 1.9 & 0.7 & 2.5 & 2.6 & 5.7 & 27.7 & 7.8 & 3.4 \\
\hline $\mathrm{Sr}$ & 141 & 111 & 198 & 113 & 265 & 21 & 134 & 429 & 427 & 346 \\
\hline$Y$ & 21 & 24 & 51 & 26 & 42 & 8 & 13 & 36 & 29 & 38 \\
\hline $\mathrm{Zr}$ & 57 & 70 & 82 & 49 & 86 & 34 & 58 & 178 & 132 & 147 \\
\hline $\mathrm{Nb}$ & 2.88 & 3.29 & 3.47 & 4.04 & 3.92 & 4.39 & 8.41 & 35.30 & 25.36 & 29.09 \\
\hline $\mathrm{Ta}$ & 0.13 & 0.16 & 0.19 & 0.27 & 0.25 & 0.15 & 0.34 & 1.94 & 1.63 & 1.69 \\
\hline $\mathrm{Cd}$ & 0.10 & 0.10 & 0.13 & 0.15 & 0.22 & 0.05 & 0.07 & 0.13 & 0.11 & 0.17 \\
\hline Cs & 0.03 & 0.05 & 0.08 & 0.005 & 0.11 & 0.04 & 0.17 & 0.13 & 0.004 & 0.05 \\
\hline $\mathrm{Ba}$ & 48 & 17 & 62 & 21 & 96 & 10 & 30 & 255 & 212 & 78 \\
\hline $\mathrm{Hf}$ & 1.43 & 1.70 & 3.35 & 2.06 & 3.52 & 1.26 & 2.14 & 6.53 & 5.11 & 5.70 \\
\hline $\mathrm{Pb}$ & 0.34 & 0.43 & 1.64 & 0.52 & 2.72 & 0.79 & 0.69 & 1.28 & 1.15 & 1.33 \\
\hline Th & 0.19 & 0.21 & 0.26 & 0.26 & 0.49 & 0.52 & 0.76 & 2.43 & 1.70 & 1.97 \\
\hline$U$ & 0.08 & 0.08 & 0.10 & 0.09 & 0.16 & 0.29 & 0.22 & 0.68 & 0.51 & 0.55 \\
\hline La & 2.46 & 3.08 & 5.13 & 3.31 & 6.31 & 4.90 & 7.95 & 24.08 & 18.42 & 20.24 \\
\hline $\mathrm{Ce}$ & 6.96 & 8.60 & 16.36 & 9.42 & 17.55 & 12.34 & 19.05 & 55.18 & 43.43 & 47.41 \\
\hline $\mathrm{Pr}$ & 1.16 & 1.41 & 2.97 & 1.57 & 3.07 & 1.60 & 2.65 & 7.73 & 6.14 & 6.67 \\
\hline $\mathrm{Nd}$ & 6.29 & 7.39 & 16.74 & 8.50 & 16.63 & 7.44 & 12.30 & 35.05 & 27.93 & 30.98 \\
\hline $\mathrm{Sm}$ & 2.21 & 2.49 & 5.54 & 2.76 & 5.20 & 1.80 & 3.00 & 8.19 & 6.54 & 7.25 \\
\hline $\mathrm{Eu}$ & 0.84 & 0.94 & 1.89 & 1.04 & 1.90 & 0.60 & 0.98 & 2.55 & 2.18 & 2.38 \\
\hline Gd & 2.93 & 3.35 & 6.97 & 3.51 & 6.34 & 1.80 & 2.92 & 7.98 & 6.58 & 7.25 \\
\hline $\mathrm{Tb}$ & 0.54 & 0.61 & 1.28 & 0.64 & 1.10 & 0.27 & 0.45 & 1.19 & 0.98 & 1.08 \\
\hline Dy & 3.52 & 3.98 & 8.87 & 4.45 & 7.39 & 1.61 & 2.66 & 7.01 & 5.84 & 6.55 \\
\hline Ho & 0.75 & 0.86 & 1.85 & 0.92 & 1.56 & 0.30 & 0.48 & 1.28 & 1.08 & 1.24 \\
\hline $\mathrm{Er}$ & 2.22 & 2.54 & 5.52 & 2.68 & 4.52 & 0.77 & 1.22 & 3.24 & 2.74 & 3.31 \\
\hline $\mathrm{Tm}$ & 0.30 & 0.35 & 0.78 & 0.38 & 0.65 & 0.10 & 0.16 & 0.43 & 0.36 & 0.45 \\
\hline $\mathrm{Yb}$ & 2.03 & 2.33 & 4.99 & 2.44 & 4.12 & 0.62 & 1.01 & 2.49 & 2.14 & 2.73 \\
\hline Lu & 0.30 & 0.35 & 0.75 & 0.37 & 0.62 & 0.09 & 0.14 & 0.37 & 0.31 & 0.40 \\
\hline
\end{tabular}


Table 4.1. Major- and trace-element composition of representative samples (continued)

\begin{tabular}{|c|c|c|c|c|c|c|c|c|c|c|}
\hline \multirow[b]{2}{*}{ Sample } & \multicolumn{5}{|c|}{ Group 3: CLIP-arc } & \multicolumn{5}{|c|}{ Group 4: Early arc } \\
\hline & $\begin{array}{c}\text { PAN- } \\
06-204\end{array}$ & $\begin{array}{c}\text { PAN- } \\
06-203\end{array}$ & $\begin{array}{c}\text { PAN- } \\
06-205\end{array}$ & $\begin{array}{c}\text { PAN- } \\
05-004\end{array}$ & $\begin{array}{c}\text { PAN- } \\
05-008\end{array}$ & $\begin{array}{c}\text { PAN- } \\
03-007\end{array}$ & $\begin{array}{c}\text { PAN- } \\
03-004\end{array}$ & $\begin{array}{c}\text { PAN- } \\
05-031\end{array}$ & $\begin{array}{c}\text { PAN- } \\
06-088\end{array}$ & $\begin{array}{c}\text { PAN- } \\
06-206\end{array}$ \\
\hline Region & Sona & Sona & Sona & Azuero & Azuero & Chagres & Chagres & $\begin{array}{l}\text { Santa Fe } \\
\text { Traverse }\end{array}$ & $\begin{array}{l}\text { Penonome } \\
\text { Loop }\end{array}$ & Bayano \\
\hline EASTING & 464621 & 464621 & 468175 & 540343 & 546883 & 681638 & 675034 & 496224 & 545793 & 787121 \\
\hline $\begin{array}{l}\text { NORTHING } \\
\text { Lithology }\end{array}$ & $\begin{array}{c}870824 \\
\text { basaltic } \\
\text { andesite }\end{array}$ & $\begin{array}{l}870824 \\
\text { andesite }\end{array}$ & $\begin{array}{c}870544 \\
\text { dacite }\end{array}$ & $\begin{array}{l}846613 \\
\text { andesite }\end{array}$ & $\begin{array}{c}831171 \\
\text { dacite }\end{array}$ & $\begin{array}{c}1020020 \\
\text { gabbro }\end{array}$ & $\begin{array}{c}1027177 \\
\text { micro- } \\
\text { diorite }\end{array}$ & $\begin{array}{l}921091 \\
\text { andesite }\end{array}$ & $\begin{array}{l}953830 \\
\text { andesite }\end{array}$ & $\begin{array}{c}1017837 \\
\text { grano- } \\
\text { diorite }\end{array}$ \\
\hline $\mathrm{SiO}_{2}$ & 54.9 & 56.6 & 64.4 & 57.0 & 59.4 & 48.6 & 53.8 & 58.3 & 57.6 & 61.6 \\
\hline $\mathrm{TiO}_{2}$ & 0.38 & 0.51 & 0.53 & 0.25 & 0.18 & 0.42 & 0.71 & 1.00 & 0.78 & 0.42 \\
\hline $\mathrm{Al}_{2} \mathrm{O}_{3}$ & 15.81 & 16.03 & 14.65 & 14.60 & 13.10 & 19.10 & 17.90 & 16.40 & 15.69 & 16.20 \\
\hline $\mathrm{Fe}_{2} \mathrm{O}_{3}$ & 9.07 & 8.36 & 5.71 & 8.68 & 7.49 & 6.37 & 7.12 & 8.10 & 7.01 & 6.09 \\
\hline $\mathrm{MnO}$ & 0.18 & 0.14 & 0.12 & 0.16 & 0.22 & 0.13 & 0.11 & 0.13 & 0.15 & 0.16 \\
\hline $\mathrm{MgO}$ & 5.86 & 4.63 & 2.28 & 5.16 & 6.45 & 7.07 & 4.53 & 2.50 & 2.50 & 2.93 \\
\hline $\mathrm{CaO}$ & 9.15 & 8.47 & 6.71 & 7.32 & 4.10 & 15.13 & 11.56 & 6.85 & 5.67 & 5.86 \\
\hline $\mathrm{Na}_{2} \mathrm{O}$ & 2.24 & 3.08 & 2.91 & 2.91 & 3.38 & 1.35 & 2.58 & 2.83 & 2.95 & 3.36 \\
\hline $\mathrm{K}_{2} \mathrm{O}$ & 0.29 & 0.40 & 0.78 & 1.95 & 0.46 & 0.51 & 0.12 & 1.92 & 3.41 & 1.09 \\
\hline $\mathrm{P}_{2} \mathrm{O}_{5}$ & 0.169 & 0.153 & 0.117 & 0.078 & 0.081 & 0.156 & 0.116 & 0.308 & 0.302 & 0.110 \\
\hline Total & 98.02 & 98.40 & 98.16 & 98.11 & 94.86 & 98.83 & 98.55 & 98.34 & 96.03 & 97.82 \\
\hline Sc & 40 & 38 & 32 & 40 & 30 & 53 & 29 & 27 & 19 & 18 \\
\hline V & 278 & 312 & 212 & 236 & 174 & 226 & 180 & 177 & 166 & 137 \\
\hline Co & 31 & 22 & 13 & 26 & 23 & 37 & 19 & 21 & 16 & 15 \\
\hline $\mathrm{Ni}$ & 35 & 25 & 10 & 13 & 31 & 43 & 25 & 6 & 6 & 10 \\
\hline $\mathrm{Zn}$ & 82 & 67 & 61 & 77 & 167 & 49 & 42 & 93 & 80 & 67 \\
\hline $\mathrm{Rb}$ & 5.3 & 8.2 & 13.6 & 23.0 & 4.4 & 8.8 & 2.3 & 39.9 & 77.6 & 18.1 \\
\hline $\mathrm{Sr}$ & 349 & 578 & 270 & 321 & 359 & 456 & 240 & 428 & 511 & 252 \\
\hline Y & 23 & 21 & 18 & 12 & 9 & 15 & 31 & 31 & 24 & 16 \\
\hline$Z r$ & 32 & 67 & 64 & 21 & 33 & 46 & 27 & 91 & 150 & 73 \\
\hline $\mathrm{Nb}$ & 0.54 & 1.58 & 1.16 & 1.25 & 1.14 & 2.20 & 1.49 & 8.08 & 9.40 & 1.44 \\
\hline $\mathrm{Ta}$ & 0.03 & 0.09 & 0.07 & 0.14 & 0.09 & 0.14 & 0.11 & 0.49 & 0.50 & 0.09 \\
\hline $\mathrm{Cd}$ & 0.10 & 0.07 & 0.06 & 0.07 & 0.25 & 0.08 & & 0.10 & 0.07 & 0.05 \\
\hline Cs & 0.16 & 1.08 & 1.38 & 0.17 & 0.07 & 0.19 & 0.01 & 0.66 & 0.91 & 0.20 \\
\hline $\mathrm{Ba}$ & 195 & 242 & 351 & 884 & 295 & 298 & 43 & 934 & 859 & 601 \\
\hline $\mathrm{Hf}$ & 0.83 & 1.76 & 1.68 & 0.99 & 1.37 & 1.39 & 0.94 & 3.66 & 3.99 & 2.05 \\
\hline $\mathrm{Pb}$ & 1.81 & 3.61 & 1.85 & 2.80 & 3.38 & 1.25 & 0.39 & 5.57 & 5.43 & 1.83 \\
\hline Th & 0.38 & 1.09 & 0.49 & 0.70 & 0.95 & 0.71 & 0.48 & 3.20 & 4.02 & 1.41 \\
\hline$U$ & 0.15 & 0.46 & 0.20 & 0.34 & 0.39 & 0.24 & 0.17 & 1.15 & 1.59 & 0.46 \\
\hline La & 4.60 & 5.86 & 4.75 & 4.12 & 7.04 & 8.53 & 4.55 & 18.09 & 20.47 & 7.80 \\
\hline $\mathrm{Ce}$ & 7.58 & 11.43 & 10.54 & 9.20 & 14.02 & 18.30 & 10.29 & 35.72 & 39.81 & 15.15 \\
\hline $\mathrm{Pr}$ & 1.41 & 1.93 & 1.79 & 1.45 & 2.15 & 2.30 & 1.71 & 5.13 & 5.19 & 2.22 \\
\hline $\mathrm{Nd}$ & 6.65 & 8.87 & 8.65 & 6.53 & 9.67 & 10.10 & 9.12 & 23.09 & 21.03 & 9.56 \\
\hline Sm & 1.79 & 2.44 & 2.41 & 1.55 & 2.14 & 2.59 & 3.16 & 5.46 & 4.51 & 2.23 \\
\hline $\mathrm{Eu}$ & 0.61 & 0.71 & 0.77 & 0.38 & 0.61 & 0.83 & 1.00 & 1.43 & 1.23 & 0.70 \\
\hline $\mathrm{Gd}$ & 2.23 & 2.89 & 2.80 & 1.66 & 1.95 & 2.91 & 4.50 & 5.52 & 4.69 & 2.30 \\
\hline $\mathrm{Tb}$ & 0.37 & 0.48 & 0.47 & 0.26 & 0.25 & 0.44 & 0.76 & 0.88 & 0.66 & 0.39 \\
\hline Dy & 2.55 & 3.10 & 3.03 & 1.82 & 1.42 & 2.58 & 5.18 & 5.66 & 4.03 & 2.57 \\
\hline $\mathrm{Ho}$ & 0.61 & 0.70 & 0.66 & 0.41 & 0.28 & 0.52 & 1.11 & 1.14 & 0.83 & 0.55 \\
\hline $\mathrm{Er}$ & 1.99 & 2.19 & 2.01 & 1.28 & 0.77 & 1.42 & 3.21 & 3.27 & 2.43 & 1.71 \\
\hline $\mathrm{Tm}$ & 0.29 & 0.32 & 0.29 & 0.20 & 0.12 & 0.20 & 0.44 & 0.48 & 0.34 & 0.26 \\
\hline $\mathrm{Yb}$ & 2.04 & 2.23 & 1.95 & 1.39 & 0.78 & 1.29 & 2.71 & 3.11 & 2.38 & 1.83 \\
\hline Lu & 0.33 & 0.35 & 0.30 & 0.22 & 0.13 & 0.20 & 0.40 & 0.48 & 0.36 & 0.30 \\
\hline
\end{tabular}


Table 4.1. Major- and trace-element composition of representative samples (continued)

\begin{tabular}{|c|c|c|c|c|c|c|c|c|c|c|}
\hline \multirow[b]{2}{*}{ Sample } & \multicolumn{5}{|c|}{ Group 5: Miocene arc } & \multicolumn{5}{|c|}{ Group 6: Adakites } \\
\hline & $\begin{array}{l}\text { PAN- } \\
06-114\end{array}$ & $\begin{array}{c}\text { PAN- } \\
05-056\end{array}$ & $\begin{array}{c}\text { PAN- } \\
06-011\end{array}$ & $\begin{array}{l}\text { PAN- } \\
03-032\end{array}$ & $\begin{array}{c}\text { PAN- } \\
06-219\end{array}$ & $\begin{array}{l}\text { PAN- } \\
05-049\end{array}$ & $\begin{array}{c}\text { PAN- } \\
06-097\end{array}$ & $\begin{array}{c}\text { PAN- } \\
06-166\end{array}$ & $\begin{array}{c}\text { PAN- } \\
06-177\end{array}$ & $\begin{array}{c}\text { PAN- } \\
06-180 \mathrm{~g}\end{array}$ \\
\hline Region & $\begin{array}{l}\text { Road to } \\
\text { Bocas }\end{array}$ & $\begin{array}{l}\text { Canal- } \\
\text { Tour }\end{array}$ & $\begin{array}{l}\text { Santa } \\
\text { Clara } \\
\text { Loop }\end{array}$ & $\begin{array}{l}\text { Coclecito } \\
\text { Traverse }\end{array}$ & Campana & $\begin{array}{c}\text { La } \\
\text { Yeguada }\end{array}$ & El Valle & Baru & Baru & Baru \\
\hline EASTING & 358387 & 644264 & 311164 & 561246 & 614431 & 515419 & 594961 & 340254 & 326350 & 330650 \\
\hline $\begin{array}{l}\text { NORTHING } \\
\text { Lithology }\end{array}$ & \begin{tabular}{|c|}
1007756 \\
basaltic \\
andesite \\
\end{tabular} & $\begin{array}{c}1000475 \\
\text { basaltic } \\
\text { andesite }\end{array}$ & $\begin{array}{r}976475 \\
\text { basaltic } \\
\text { andesite }\end{array}$ & $\begin{array}{r}956056 \\
\text { basaltic } \\
\text { andesite }\end{array}$ & $\begin{array}{c}954900 \\
\text { dacite }\end{array}$ & $\begin{array}{l}932671 \\
\text { dacite }\end{array}$ & $\begin{array}{c}953725 \\
\text { dacite } \\
\end{array}$ & $\begin{array}{r}973213 \\
\text { andesite }\end{array}$ & $\begin{array}{r}955330 \\
\text { andesite }\end{array}$ & $\begin{array}{c}973680 \\
\text { basaltic } \\
\text { andesite }\end{array}$ \\
\hline $\mathrm{SiO}_{2}$ & 52.2 & 51.4 & 52.6 & 55,2 & 62,6 & 69,1 & 64,2 & 57,2 & 57,0 & 54,9 \\
\hline $\mathrm{TiO}_{2}$ & 0.84 & 1.70 & 0.88 & 0,76 & 0,56 & 0,28 & 0,22 & 0,72 & 0,73 & 0,72 \\
\hline $\mathrm{Al}_{2} \mathrm{O}_{3}$ & 21.50 & 16.00 & 17.18 & 15,60 & 16,70 & 16,10 & 15,72 & 16,80 & 16,50 & 16,30 \\
\hline $\mathrm{Fe}_{2} \mathrm{O}_{3}$ & 5.70 & 11.18 & 9.08 & 8,72 & 5,07 & 1,56 & 2,37 & 6,54 & 6,28 & 7,05 \\
\hline $\mathrm{MnO}$ & 0.20 & 0.18 & 0.35 & 0,17 & 0,06 & 0,04 & 0,06 & 0,11 & 0,10 & 0,12 \\
\hline $\mathrm{MgO}$ & 1.91 & 4.19 & 3.91 & 4,78 & 1,86 & 0,74 & 0,84 & 3,44 & 3,30 & 6,39 \\
\hline $\mathrm{CaO}$ & 6.94 & 8.53 & 8.65 & 8,40 & 5,72 & 2,96 & 4,19 & 7,48 & 6,64 & 8,03 \\
\hline $\mathrm{Na}_{2} \mathrm{O}$ & 4.22 & 3.55 & 2.95 & 2,31 & 3,62 & 4,47 & 4,64 & 2,95 & 2,80 & 3,31 \\
\hline $\mathrm{K}_{2} \mathrm{O}$ & 3.31 & 0.71 & 1.85 & 2,31 & 1,56 & 2,70 & 1,40 & 2,40 & 3,03 & 1,36 \\
\hline $\mathrm{P}_{2} \mathrm{O}_{5}$ & 0.478 & 0.458 & 0.290 & 0,272 & 0,149 & 0,110 & 0,099 & 0,242 & 0,289 & 0,202 \\
\hline Total & 97.30 & 97.89 & 97.78 & 98,52 & 97,90 & 98,07 & 93,73 & 97,87 & 96,67 & 98,37 \\
\hline $\mathrm{Sc}$ & 6 & 36 & 27 & 29 & 13 & 2 & 3 & 18 & 9 & 17 \\
\hline V & 147 & 308 & 249 & 245 & 128 & 24 & 37 & 197 & 120 & 165 \\
\hline Co & 12 & 31 & 28 & 33 & 15 & 4 & 5 & 22 & 15 & 23 \\
\hline $\mathrm{Ni}$ & 7 & 24 & 46 & 33 & 21 & 5 & 4 & 27 & 29 & 73 \\
\hline $\mathrm{Zn}$ & 97 & 110 & 92 & 81 & 59 & 33 & 37 & 72 & 72 & 74 \\
\hline $\mathrm{Rb}$ & 28.5 & 13.5 & 27.3 & 51,50 & 18,65 & 28,57 & 12,25 & 43,30 & 46,00 & 33,60 \\
\hline $\mathrm{Sr}$ & 1334 & 446 & 1571 & 585 & 300 & 706 & 670 & 1500 & 1250 & 1030 \\
\hline Y & 22 & 35 & 17 & 23 & 23 & 5 & 4 & 13 & 8 & 10 \\
\hline $\mathrm{Zr}$ & 163 & 113 & 123 & 124 & 93 & 36 & 62 & 139 & 121 & 100 \\
\hline $\mathrm{Nb}$ & 14.34 & 10.71 & 6.58 & 7,83 & 4,71 & 11,92 & 1,89 & 5,70 & 8,53 & 6,40 \\
\hline $\mathrm{Ta}$ & 0.66 & 0.64 & 0.33 & 0,41 & 0,30 & 0,76 & 0,11 & 0,32 & 0,48 & 0,36 \\
\hline $\mathrm{Cd}$ & 0.04 & 0.17 & 1.65 & 0,18 & 0,05 & 0,03 & 0,02 & 0,03 & 0,03 & 0,06 \\
\hline Cs & 2.45 & 0.14 & 0.40 & 0,56 & 0,17 & 0,72 & 0,18 & 0,62 & 0,59 & 0,51 \\
\hline $\mathrm{Ba}$ & 1354 & 344 & 850 & 1100 & 546 & 1336 & 475 & 1065 & 1175 & 856 \\
\hline $\mathrm{Hf}$ & 3.68 & 3.93 & 3.27 & 2,92 & 2,78 & 1,76 & 1,78 & 3,78 & 3,34 & 2,68 \\
\hline $\mathrm{Pb}$ & 14.15 & 5.50 & 6.22 & 4,59 & 2,23 & 7,85 & 4,34 & 7,58 & 6,60 & 4,98 \\
\hline Th & 5.55 & 2.10 & 5.79 & 2,64 & 1,82 & 9,08 & 2,12 & 6,36 & 6,81 & 4,05 \\
\hline$U$ & 1.35 & 0.66 & 1.52 & 1,07 & 0,51 & 1,96 & 0,82 & 2,01 & 2,03 & 1,30 \\
\hline $\mathrm{La}$ & 34.09 & 19.41 & 32.57 & 18,20 & 11,88 & 26,01 & 6,35 & 28,10 & 31,00 & 21,40 \\
\hline $\mathrm{Ce}$ & 60.44 & 39.55 & 57.06 & 36,00 & 20,44 & 48,72 & 13,64 & 54,70 & 57,70 & 40,00 \\
\hline $\mathrm{Pr}$ & 8.93 & 5.33 & 7.73 & 4,34 & 3,09 & 5,00 & 1,69 & 6,65 & 6,51 & 4,74 \\
\hline $\mathrm{Nd}$ & 35.67 & 23.72 & 30.15 & 18,20 & 13,26 & 17,06 & 6,66 & 26,10 & 24,47 & 18,53 \\
\hline $\mathrm{Sm}$ & 6.38 & 5.69 & 5.31 & 4,11 & 2,85 & 2,40 & 1,28 & 4,56 & 3,87 & 3,26 \\
\hline $\mathrm{Eu}$ & 2.06 & 1.86 & 1.54 & 1,30 & 0,87 & 0,63 & 0,42 & 1,35 & 1,13 & 1,02 \\
\hline $\mathrm{Gd}$ & 5.27 & 6.19 & 4.44 & 4,51 & 3,12 & 1,72 & 1,13 & 3,74 & 2,92 & 2,66 \\
\hline $\mathrm{Tb}$ & 0.70 & 0.98 & 0.53 & 0,65 & 0,49 & 0,19 & 0,14 & 0,45 & 0,33 & 0,34 \\
\hline Dy & 4.07 & 6.40 & 2.97 & 3,84 & 3,20 & 0,98 & 0,76 & 2,52 & 1,73 & 1,96 \\
\hline Ho & 0.78 & 1.29 & 0.57 & 0,80 & 0,70 & 0,18 & 0,15 & 0,46 & 0,31 & 0,37 \\
\hline $\mathrm{Er}$ & 2.12 & 3.67 & 1.54 & 2,29 & 2,15 & 0,41 & 0,39 & 1,22 & 0,77 & 1,00 \\
\hline $\mathrm{Tm}$ & 0.31 & 0.52 & 0.21 & 0,33 & 0,31 & 0,06 & 0,06 & 0,17 & 0,11 & 0,14 \\
\hline $\mathrm{Yb}$ & 2.07 & 3.43 & 1.44 & 2,15 & 2,03 & 0,42 & 0,40 & 1,10 & 0,69 & 0,94 \\
\hline Lu & 0.31 & 0.51 & 0.22 & 0,34 & 0,33 & 0,07 & 0,06 & 0,16 & 0,11 & 0,14 \\
\hline
\end{tabular}


Variations in major element composition for the igneous rocks of the Cordillera de Panama are illustrated in the total alkali-silica diagram (Fig. 4.3). With few exceptions, all rocks are subalkaline, and the suite of samples spans the entire compositional range from basalt and gabbro to rhyolite and tonalite/granite. Higher $\mathrm{Na}_{2} \mathrm{O}+\mathrm{K}_{2} \mathrm{O}$ values (i.e., mildly alkaline rocks) could contain an introduced effect resulting from secondary alteration. These samples have been omitted.

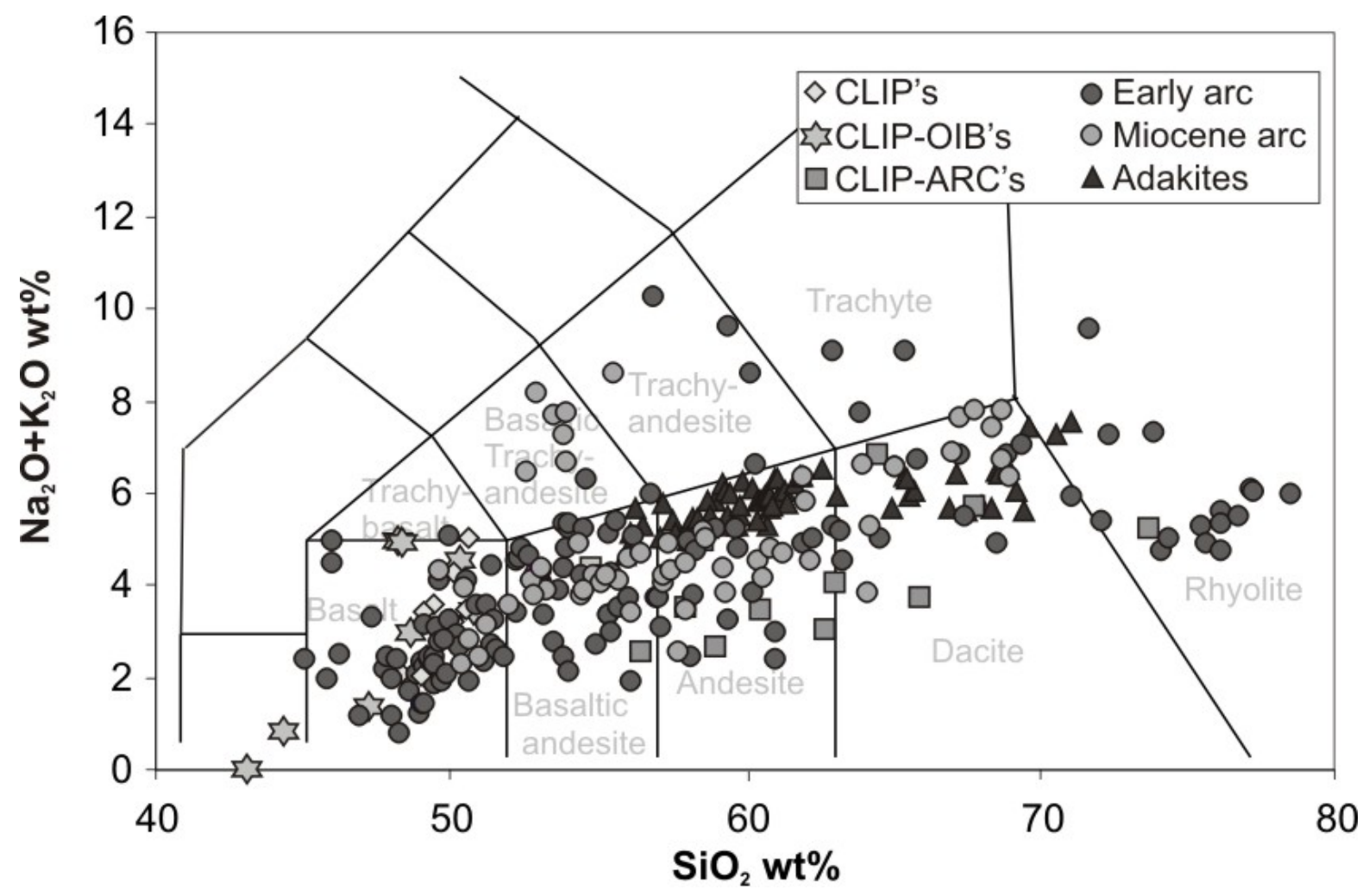

Figure 4.3. Total Alkali - Silica diagram for the volcanic and intrusive rocks from central and western Panama analyzed in this study. CLIP - Caribbean large igneous province; OIB - ocean-island basalt; ARC - arc rocks of variable age.

The remaining samples were subdivided into four groups, based on their age and tectonic setting.

(1) Compositional data from CLIP oceanic basement rocks have been compiled from a range of localities throughout Central America (Nicoya, Azuero, Soná Peninsulas and other minor occurrences; Hoernle et al. 2002, 2004; Hauff et al., 2000, 1997; Sinton et al., 1997, 1998) and combined with own data from Soná, Azuero and Nicoya. CLIP rocks have been dated by Hoernle et al. $(2002,2004)$. These rocks have been further divided on the basis of their trace element signatures (as 
discussed later) into: (a) oceanic basement rocks of the Caribbean plate from 139 to $55 \mathrm{Ma}$ (AN8: $139 \pm 1 \mathrm{Ma}$ from Hoernle et al. [2004]; OS4: $55 \pm 2$ Ma from Hoernle et al. [2002]), (b) rocks from accreted ridges and ocean-island complexes as young as $21 \mathrm{Ma}$ (G22: 21 \pm 1 Hoernle et al. 2002), and (c) rare samples from the CLIP terranes from Soná, Azuero that have a clear subduction-zone signature of unknown age (this paper and Buchs et al., 2007).

(2) "Early" arc rocks are defined as those between 66 and $42 \mathrm{Ma}$, which are dominated by samples from the Chagres Igneous Complex. These mostly represent deeply exposed sections of submarine volcanic and volcaniclastic rocks and intrusions that range in composition from gabbro to tonalite.

(3) Miocene arc rocks are from central and western Panama, and they erupted between 36-5 Ma.

(4) Pliocene-Holocene rocks exhibit steep heavy REE (HREE) patterns, which occur in the "magmatic gap" of south-eastern Costa Rica and western Panama (previously referred to as "adakites" by Defant et al. [1991a, 1991b]; Abratis and Wörner, 2001). The following sections will concentrate on the trace-element signatures for rocks in these groups in order to identify the change of magma sources through time.

\subsubsection{Age, Composition and Mantle Source of CLIP Terranes}

The oldest known rocks in the central portion of the Central American land bridge are terranes of oceanic basalt from the Nicoya peninsula in Costa Rica; (Fig. 4.1) which yield ages between 139 and $111 \mathrm{Ma}$ (Hoernle et al., 2004). Younger CLIP ages down to 55 have also been found (Hauff et al., 2000a, Hoernle et al., 2004, 2002 and references therein). With respect to the initiation of subduction zone magmatism (66 $\mathrm{Ma}$, see following) it is interesting to note that the accretion of seamounts from the Galapagos hot spot track (ocean-island basalts) commenced at $66 \mathrm{Ma}$ (data compilation in Hoernle et al, 2004). The oldest CLIP rocks in Panama come from the Azuero peninsula (Fig. 4.1) where most ages range between 50 an $66 \mathrm{Ma}$ (Hoernle et al, 2002), one sample from Soná gave $71 \pm 2 \mathrm{Ma}$, which is the oldest dated rock in Panama (Hoernle et al., 2002, see also compilation by Hoernle and Hauff, 2007). Hoernle and other workers (Hoernle et al. 2002; Hauff et al., 2000, 1997; Sinton et al., 1997, 1998) documented the geochemical and isotopic signature of these rocks. As originally noted by Goossens et al. (1977), the larger basaltic terranes are tholeiitic in character (Hoernle et al. 2004). Younger (20-66 Ma) and smaller 
occurrences represent intraplate ocean-island basaltic (OIB) rocks (i.e., seamounts) from the hotspot track that have accreted onto the evolving active margin since 66 Ma.
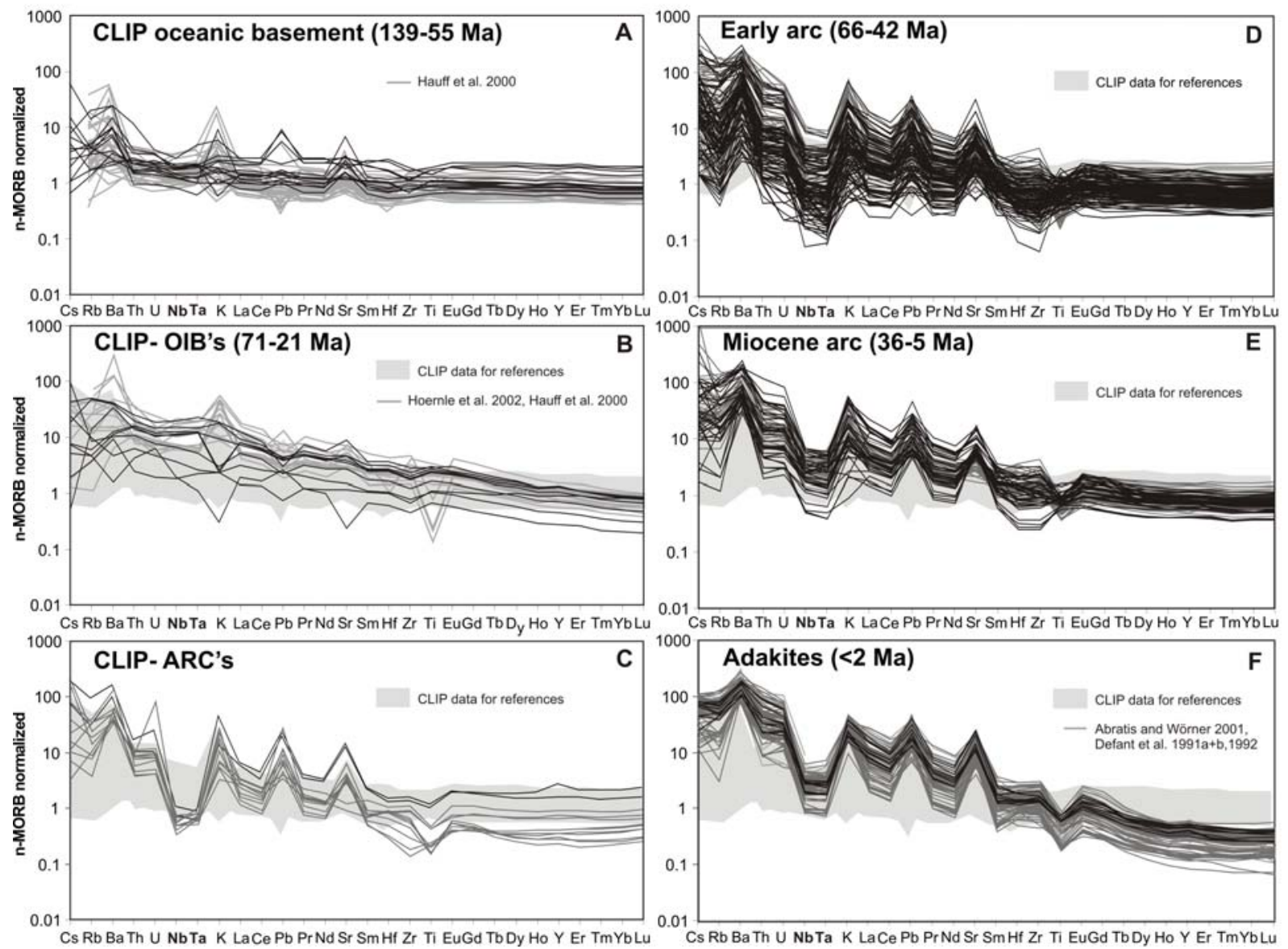

Figure 4.4. Chondrite-normalized (following Sun and McDonough, 1989) trace element patterns for volcanic and intrusive rocks from central and western Panama. The data set has been filtered for compositions with $<57 \% \mathrm{SiO}_{2}$ in black and $>57 \%$ $\mathrm{SiO}_{2}$ in dark grey to avoid effects of fractional crystallization and variable degrees of melting on the trace-element patterns. Light grey paterns are literature data from Hoernle et al. (2002, 2004). (A) Caribbean large igneous province (CLIP) oceanic basement from Azuero and Soná. The CLIP field is also given for reference in the other diagrams to aid comparison. (B) Accreted ocean-island basalt (OIB) terranes derived from the Galapagos hot-spot. Plots $A$ and $B$ include published analyses from Hoernle et al (2002) for reference. (C) Rare arc-rocks from Azuero and Soná. (D) "Early" arc rocks (66-42 Ma) that are dominated by a large set of samples from the Chagres Igneous Complex. (E) Miocene arc centers of the Cordillera de Panama of western Panama, (F) Adakites (including data from Abratis and Wörner, 2001 and Defant et al, 1991a, 1991b). ARC-arc rocks of variable age; n-MORB-normal midoceanic-ridge basalt. See text for further discussion.

The trace element patterns of CLIP rocks described by Hauff et al. $(2000,1997)$ and our new data set from west-central Panama are typically flat or only slightly enriched 
(Fig. 4.4A). The scatter in some mobile elements $(\mathrm{K}, \mathrm{Sr}, \mathrm{Ba})$ is attributed to secondary, low-temperature hydrothermal alteration of these submarine basalts and should not be taken as a subduction- zone signature. Younger (70-20 Ma) accreted terranes are invariably more enriched in incompatible trace elements, akin to an intra-plate OIB signature, and can be related to the Galapagos hot spot track (Hoernle et al., 2002; Fig. 4.4B). In addition to these CLIP and Galapagos-derived OIB rocks, rocks of undoubted arc signature (12 samples) have been found that are associated with the Azuero and Soná CLIP terranes (Fig. 4.4C). Similar arc rocks have also been reported from Osa peninsula in SE Costa Rica (Fig. 4.1; Buchs et al., 2007). These enigmatic rocks may hold significant clues to the earliest volcanic arc development along the southern margin of the Caribbean plate. At this point, however, information about their structural relations with CLIP rocks and ages is lacking due to insufficient outcrop and the absence of datable material.

\subsubsection{The "Early" Arc in Central Panama (66-42 Ma)}

Our sampling and analytical work on these rocks concentrated on the Chagres igneous complex located in the mountains east of the Panama Canal (Fig. 4.1). The deepest and oldest sections of the Central American arc are exposed in this region. As a consequence of an international, multidisciplinary research project on the Rio Chagres watershed (Harmon, 2005), the region was accessed and its geology studied.

The geological basement of the Chagres region consists of hydrothermally-altered submarine volcanic rocks represented by highly deformed basalts, basaltic andesites as sheet flows, rare pillow lavas and volcaniclastic sequences. These are intruded by dike swarms, some of which evolve into intrusive complexes as multiple dike injection inflated the intrusions. Gabbros, and diorites with chemically more evolved granodiorites, tonalities, and granites are also common. Younger and relatively undeformed basaltic andesite/andesite dikes and dike complexes crosscut all lithologies. Intercalated volcaniclastic breccias and rare sandstones have also been observed. Rare oxidized scoria in volcanic debris flows provides evidence for subaerial eruptions and their redeposition on the seamount flanks. The Chagres igneous complex thus represents a deeply eroded section of a submarine lava flowdike complex, associated with overlying and intercalated volcanic breccias, and subvolcanic intrusive rocks, dike swarms, and large intrusive complexes of gabbroic 
composition. Our geological reconstruction envisages a large, mostly submarine seamount and volcanic island complexes with large magma chambers represented by the intrusions. The predominance of sheet flows and abundance of dikes and larger intrusive bodies suggests a relatively high eruption rate for these submarine volcanoes. Ultramafic rocks, that would provide evidence for an ultramafic oceanic basement (i.e., mid-ocean-ridge basalt [MORB] crust or oceanic mantle) in the Chagres region, are absent. Most rocks, in particular the volcanics, volcaniclastic sediments and granites, show evidence of brittle deformation along shear zones, sometimes grading into mylonites. Chemical alteration is ubiquitous in these submarine rocks, but mineralizations by sulfides are primarily observed near the fault zones.

On a water-free normalized basis, major element concentrations vary from (rare) ferro-gabbros with $45 \% \mathrm{SiO}_{2}$ to granites that have $78.5 \% \mathrm{SiO}_{2}$. Potassium contents are generally below $1 \%$, often much lower. This attests both to the initially low $\mathrm{K}_{2} \mathrm{O}$ contents of many rocks and the post-emplacement low-temperature chemical alteration. The majority of rocks (about $60 \%$ of the samples analyzed) have $\mathrm{SiO}_{2}$ contents that range between $48 \%$ and $57 \%$. Rocks of intermediate composition, such as amphibole-bearing andesites, are present but rare. In essence, the rocks of the Chagres igneous complex define an assemblage that is bimodal in composition between basalts, basaltic andesites, and their intrusive counterparts, on the one hand, and granodiorites, tonalites and granites, on the other.

Normalized trace element patterns (Fig. 4.4D) display typical arc signatures i.e., depletions in $\mathrm{Nb}$ and $\mathrm{Ta}$ and enrichment in fluid-mobile elements such as $\mathrm{Sr}, \mathrm{Pb}, \mathrm{K}$, and $\mathrm{Ba}$. Note, however, that the less incompatible trace elements on the right side of the diagram have a flat pattern and are similar in elemental abundances to CLIP rocks. The large range in $\mathrm{Nb}$ and $\mathrm{Ta}$ abundances is quite distinct, however, and trace element patterns show $\mathrm{Nb}-\mathrm{Ta}$ troughs of highly variable magnitude reflected by variable $\mathrm{Nb}$ and $\mathrm{Ta}$ values and a relatively large range in $\mathrm{Ba} / \mathrm{Nb}$ ratios. Both of these observations argue for a mantle wedge with variable extents of enrichment prior to the influence of a (large ion lithophile element [LILE]-enriched) slab fluid. In comparison, the early arc mantle wedge was initially highly variable, i.e., partly more depleted and partly more enriched relative to the earlier CLIP mantle source. This compositionally variable mantle was then subsequently overprinted by slab components from a subducted oceanic plate, which resulted in enrichment of the 
fluid-mobile elements. It is interesting to note, that the (as yet undated) arc rocks from the CLIP terranes (see previous discussion; Buchs et al., 2007) are more restricted in composition with respect to normalized $\mathrm{Nb}$ and Ta vales compared to these (younger ?) early arc rocks.

Age dating of these arc rocks has been initiated using Ar-Ar techniques and initial results indicate ages between 66 and $42 \mathrm{Ma}$ (Wörner et al., 2006).

Further east in Panama, "early" arc rocks consisting of low-K gabbros, tonalities, granites, and andesites with similar ages of 61-55 Ma have been reported by Maury et al., (1995) from areas between the Panama Canal and the Darien region. Thus, the first occurrence of arc magmatism in Panama is dated at $66 \mathrm{Ma}$ (Maury et al., 1995; Buchs et al., 2007). Although the compiled data for this group of "early" arc rocks are dominated by the large set of samples from the Chagres igneous complex (Fig. 4.4) there is no systematic difference in composition between these "early" arc rocks and other arc rocks in western Panama of similar age.

A primary conclusion drawn from these observations and our initial age data (Wörner et al., 2006 and Buchs et al, 2007) is that subduction and arc magmatism commenced around $66 \mathrm{Ma}$, lasted until at least $42 \mathrm{Ma}$, and involved large volumes of low-K tholeiitic basaltic magmas and their derivatives. Even though most CLIP ages are significantly older than the onset of arc magmatism, there is in fact some overlap in ages between 50 and $66 \mathrm{Ma}$ (see compilation by Hoernle and Hauff, 2007) between CLIP basement and arc magmatism. It is interesting to note, that Hoernle et al. (2004) concluded that OIB seamounts began to be accreted onto CLIP basement at around $66 \mathrm{Ma}$. We, therefore, conclude that there should have been a significant rearrangement in the plate-tectonic setting in Panama at the Cretaceous-Tertiary boundary, which is expressed in the onset of subduction and arc magmatism at that time.

The highly variable range of trace element patterns represents both tholeiitic and calk-alkaline magmas and this implies that the mantle source either changed or remained variable during this period (66 Ma to $42 \mathrm{Ma}$ ), and thus is geochemically distinct compared to that from which the older CLIP magmas were derived more than 70 m.y. ago. As sufficient age data on this series of rocks is lacking, it is not possible to determine at what time the change from tholeiitic to calc-alkaline magmas occurred within the age range of 66-42 Ma, and whether or not it was synchronous across western and central Panama. A similar change has been documented for arc 
rocks in Costa Rica, however, at a much more recent time (17 Ma; Alvarado et al., 1992; Abratis and Wörner, 2001).

\subsubsection{The Miocene Arc (36 to $5 \mathrm{Ma}$ )}

Younger sections of volcanic arc rocks occur along the entire Cordillera de Panama in west-central Panama (Drummond et al., 1995; de Boer et al., 1988, 1991). The oldest K-Ar ages for this group of rocks fall in the range of 36-29 Ma (Kesler et al., 1977). These rocks are calc-alkaline andesites and dacites located within the Cordillera de Panama, where morphological expression of these volcanic centers is poor due to deep erosion and cover by younger deposits. This may be the reason why these Miocene arc centers can easily be overlooked, as emphasized by de Boer et al. (1991) and Maury (1995). However, series of younger stratovolcanoes and isolated centers in the Cordilleran and forearc regions have been identified on the basis of morphology and have yielded $\mathrm{K}-\mathrm{Ar}$ and $\mathrm{Ar}-\mathrm{Ar}$ ages from 21 to $5 \mathrm{Ma}$ (de Boer et al., 1988, 1991; Defant et al., 1992; Drummond et al., 1995; this study).

Trace element patterns of all "younger arc" rocks (younger than $35 \mathrm{Ma}$ ) have a lesspronounced $\mathrm{Nb}-\mathrm{Ta}$ depletion relative to LILE compared to older arc rocks in this region, and, in contrast to the volcanic rocks produced during the earlier period of magmatism, very few of the Miocene arc rocks have depleted trace element patterns (i.e., $\mathrm{Nb}$ and Ta normalized concentrations below 1; Fig. 4.4E). This indicates that the change from (depleted) tholeiitic trace-element patterns to more mature (enriched) arc magmatism must have been completed prior to $36 \mathrm{Ma}$, which is significantly earlier than in Costa Rica (17 Ma; Alvarado et al., 1992; Drummond et al., 1995; Abratis and Wörner, 2001).

\subsubsection{Magmatic Gap and HREE-depleted Andesites and Dacites (<2 Ma)}

"Normal" arc magmatism in Central Panama ceased at around $6 \mathrm{Ma}$. Londsdale and Klitgord (1978) first identified a gap in magmatism between about ca. 6 and $3 \mathrm{Ma}$ in west-central Panama and southeastern Costa Rica. Following this magmatic gap, younger volcanic products (1-3 Ma) are invariably HREE-depleted rocks (Abratis and Wörner 2001; Fig. 4.4F). This observation is explained by the cessation of active spreading in the Panama Basin during late Miocene time. More recently, the Pleistocene uplift of the Cordillera de Talamanca in the region where young arc volcanoes are absent was proposed to have been caused by the collision of the 
Cocos Ridge with the subduction zone in southern Costa Rica. As discussed by Abratis and Wörner (2001), the timing of this collision was determined from sedimentological and tectonic evidence as having occurred between 3 and $4 \mathrm{Ma}$ (von Eynatten et al., 1993; Krawinkel et al., 2000). However, Silver et al (2004) presented evidence that a first "disturbance" in the deep-marine environment occurred at 8-10 $\mathrm{Ma}$, which may have been related to the initiation of collision. However, the cessation of "normal" arc magmatism throughout Panama at this early time probably must have had a different cause, since the full ridge collision and associated Cordilleran uplift occurred much later, and uplift is only located in the present Cordillera de Talamanca. Rather, as indicated by Londsdale and Klitgord (1978), the convergence between the Cocos Plate and Panama, and thus also active subduction, stopped at this time as plate motions were progressively accommodated inside the Caribbean plate by the Panama Deformed Belt (Fig. 4.1). In essence, there are two unrelated causes for the magmatic gap in southern Costa Rica and Panama: (1) a platetectonic rearrangement after cessation of subduction of the Cocos Plate throughout Panama at $6 \mathrm{Ma}$, and (2) the collision of the Cocos Ridge in Costa Rica beginning at about 4 to 5 m.y. ago.

Following this evolution, scattered volcanic centers in southern Costa Rica, as well as a few large stratovolcanoes in western Panama, erupted andesites and dacites with an unusually depleted heavy REE character (Fig. 4.4F, Defant et al., 1991a, 1991b; Johnston and Torkelson, 1997). This particular trace-element pattern in arc rocks has been attributed to the melting of basalts at high pressure under conditions where garnet is a stable residual phase (Defant et al., 1991a, 1991b; Drummond et al., 1995; Kay et al., 1993; Johnston and Torkelson, 1997; Abratis and Wörner, 2001, Goss and Kay, 2007). A slab window and melting of Cocos plate MORB following subduction of the Panama spreading center have been proposed as an explanation (Johnston and Torkelson, 1997; Thorkelson and Breitsprecher, 2005). An alternative view was presented by Abratis and Wörner (2001), who argued that the Pb-isotope composition of these rocks is not consistent with the melting of MOR basalts and, therefore, favored melting of the leading edge of the Cocos ridge after its collision with the Central American land bridge as an alternative explanation. Fig. 4.4F includes data for El Baru volcano in westernmost Panama from this study and that from other centers in the Cordillera de Panama and in southern Costa Rica (Defant et al., 1991a, 1991b; Drummond et al., 1995; Abratis and Wörner, 2001). All HREE- 
depleted arc rocks in this region have very similar trace-element patterns. In addition to the fact that Cocos plate MORB is inconsistent with the $\mathrm{Pb}$-isotope composition of these rocks, preliminary trace-element modeling requires a basaltic precursor more enriched in incompatible trace elements compared to MORB. From both of these lines of evidence, we conclude that likely sources for these HREE-depleted andesites and dacites include CLIP basement or Galapagos ridge basalts (e.g., from subducted portions of the Cocos or Coiba Ridge).

\subsection{DISCUSSION: CHANGING MANTLE SOURCES THROUGH TIME}

This work has documented systematic variations in magma compositions for Tertiary volcanic and intrusive rocks (66-6 Ma) from west-central Panama based on a compilation of published and new data. These compositional variations reflect changing magma sources and mantle source compositions over the last 66 m.y. On a wider scope, the igneous basement of the Central American land bridge has been constructed since ca. $139 \mathrm{Ma}$ from basaltic rocks derived from a large oceanic igneous province (CLIP) produced by the Galapagos plume (Hauff et al., 1997, 2000, Hoernle et al., 2002, 2004; Sinton et al., 1997, 1998; Thompson et al., 2004). At this time, the thickened CLIP oceanic crust must have been underlain by a plume-mantle, which had been variably mixed with asthenospheric mantle material during plume ascent and spreading below the lithosphere (Hoernle et al., 2004; Sinton et al., 1997, 1998; Thompson et al., 2004). Magmas, which subsequently were derived from this mixed plume mantle until $55 \mathrm{Ma}$ (Hoernle et al., 2004) range from 1 to 30 in chondrite-normalized compositions for the most incompatible high field strength elements (HFSEs) such as $\mathrm{Nb}$ and $\mathrm{Ta}$, whereas $\mathrm{Zr}$ contents are much more restricted (Fig. 4.4A, and 4.4B). It is important to note that arc magmatism ("early arc"; Fig. 4.4D) followed directly after the main phase of CLIP magmatism from 66 Ma onward. Immobile HFSEs, which should be unaffected by enrichments from the subducting slab, exhibit a similar range of chondrite-normalized trace-element contents as the CLIP rocks, but they extend to much lower values $(0.01$ for chondritenormalized $\mathrm{Nb}$ and $\mathrm{Ta}$ ). The mantle wedge of the "early" arc system consisted of mantle material that was only in part similar to that of the previously underlying the Caribbean plate: it contained, in addition, a much more depleted component. Either a depleted asthenospheric mantle, which was underlying the plume source, was introduced in the melting region of the arc mantle wedge, or an entirely new, depleted 
mantle source was introduced into the melting region of the arc rocks laterally. In any case, arc magmatism initiated with a large melt volumes and eruption rates in an almost entirely marine setting at $66 \mathrm{Ma}$, as documented by the Chagres igneous complex and other age data (Maury et al., 1995, Buchs et al., 2007). The enigmatic arc rocks in the CLIP terranes all have relatively low $\mathrm{Nb}$-Ta contents compared to CLIP rocks, and were entirely derived from a depleted mantle source. However, the "early arc" rocks, while showing an overall large range in $\mathrm{Nb}$ and Ta values, include compositions that were derived from an even more depleted mantle. The large variation in early arc rocks (Fig. 4.4D) could represent a transitional phase of magmatism when subduction was initially established. We do not know the ages of the enigmatic arc rocks found on CLIP terranes (Fig. 4.4C), but if an age around 65 Ma from Osa peninsula (Buchs et al., 2007) is confirmed for other occurrences on Soná and Azuero, then these CLIP-arc rocks could hold a clue to our better understanding of arc initiation at the Cretaceous-Tertiary boundary in Central America. High-precision age dating of these rocks is necessary to better constrain changing plate arrangements at this time.

Based on existing evidence, we propose a major plate-tectonic rearrangement at this time (55 to $65 \mathrm{Ma}$ ) which involved: (1) initiation of voluminous submarine arc magmatism in Panama, (2) a sudden change in magma sources towards variably depleted mantel and strong slab fluid signatures, (3) onset of seamount accretion onto the active southern Caribbean plate margin, (4) cessation of CLIP magmatism. With time, and increasing maturation of the arc system, the mantle source beneath the Cordillera de Panama became more homogeneous. Chondrite-normalized $\mathrm{Nb}-\mathrm{Ta}$ values for volcanic rocks erupted between 66 and $36 \mathrm{Ma}$ cluster in a restricted compositional range (Fig. 4.4E). Two interpretations, or possibly some combination thereof, can explain this observation: either the mantle wedge became thoroughly mixed and homogenized and/or the mantle wedge was replaced by a more homogeneous mantle. In either case, two conclusions can be drawn: (1) strongly depleted mantle material, which gave rise to magmas with chondrite-normalized $\mathrm{Nb}$ Ta values near 0.01 ceased to exist in central Panama, and $(B)$ the mantle wedge and the subduction system must have changed significantly between the "early" arc and the Miocene arc system. One possibility that can explain this change in mantle sources is the tectonic reorganization of the Pacific plate after the breakup of the Farrallon plate at around this time (Londsdale, 2005). Arc magmatism appears to 
have been derived from the same, relatively homogeneous mantle wedge between 36-5 Ma, since large compositional heterogeneities or changes in trace-element signatures are not observed during this time.

As indicated by both morphological evidence and age-dating, "normal" arc magmatism ceased in southern Costa Rica and west-central Panama at ca. $5 \mathrm{Ma}$ as the consequence of a major change in tectonic setting and dynamics of the subduction system. Renewed, but highly localized magmatic activity in western Panama since about $2 \mathrm{Ma}$ is characterized by HREE-depleted andesites and dacites (adakites) that have similar radiogenic isotope signatures to Galapagos-derived CLIP and OIB basalts (Hoernle et al., 2004; Abratis and Wörner, 2001).

We consider that (1) cessation of "normal" arc magmatism around $5 \mathrm{Ma}$, (2) uplift of the Cordillera de Talamanca in southeastern Costa Rica and western Panama, (3) collision of the Cocos and Coiba ridge, and (4) development of the Panama fracture zone and Panama deformed belt (Fig. 4.1) are all related events that resulted in little to no plate convergence and thus the end of active subduction below Panama as documented by Mann and Kolarsky (1995). Apparently, another major plate rearrangement also occurred at this time. "Occom's razor" principle (i.e., that the simplest explanation tends to be the correct one), demands that all these events should be in some way related to one another and also to the origin of the HREEdepleted andesite and dacite magmatism in this region. Since the geochemical data strongly indicate that Galapagos ridge material, rather than Cocos plate MORB, was the precursor to these magmas and, because the crust in Panama is not sufficiently thick to stabilize garnet in the residue of partial melting, one is left with two options to explain the observed HREE-depleted magmatic geochemistry. (1) Westernmost Panama is underlain by a slab window and melting occurs at the leading edge of subducted Cocos and Coiba Ridge (Abratis and Wörner, 2001), or (2) that CLIP- and ridge-type material is being tectonically eroded and involved in the magma source region (Goss and Kay, 2007, and discussion therein). In the course of such tectonic erosion (v. Huene and Scholl, 1991), material from the upper plate may be removed (tectonically eroded), subducted below western Panama and southeastern Costa Rica and then partially melted in the region of magma generation of the subduction zone (Goss and Kay, 2007). More "normal" arc magmatism is absent in the region, and thus subduction, slab dehydration, and mantle-wedge melting do not occur here. At the same time, arc magmatism is observed in abundance to the northwest and 
southeast, respectively (Carr et al., 1990), of the arc magmatic gap in northwestern Costa Rica and northern Colombia. Therefore, we find it difficult to envision melting of tectonically eroded material only occurs where normal arc magmatism is absent, even though CLIP and Galapagos Ridge basalts occur (and may become tectonically eroded almost everywhere along the leading upper plate). Thus, we favor instead an interpretation involving slab window formation and melting of the exposed leading edges of subducted oceanic ridges that were originally derived from the Galapagos hot spot. De Boer et al. (1995) suggested that mantle-wedge material was introduced to the northwest below Central Costa Rica and to the southeast (western-most Panama) by the subducted mass of the Cocos Ridge. A similar idea was postulated by Hoernle et al. (2008), who argued, based mainly on $\mathrm{Pb}$-isotopic composition of arc rocks, that a geochemical component from the subducted seamount chain and ridges can be identified in the arc magma source below Costa Rica. We would like to emphasize that at present, the plate-tectonic situation is highly complex, that geochemical signatures in arc magmas can be highly varied, and that mantle sources could move laterally. In this context, it is very difficult to interpret the compositional characteristics observed for rocks from Panama, which are highly variable spatially, cover a time span of many millions of years in a plate-tectonic setting that may have changed rapidly and may have been equally complicated in the past as it is today.

\subsection{SUMMARY AND CONCLUSIONS}

The geologic development of Panama can be divided into four stages: (1) development of a genetically complex basement prior to about $70 \mathrm{Ma}$, (2) development of an "early" volcanic arc between ca. 65 and $40 \mathrm{Ma}$, (3) development of a "younger" volcanic arc between ca. 40 and $5 \mathrm{Ma}$, and (4) localized HREEdepleted magmas since ca. 2 Ma. Three distinct trace element signatures are recognized in the oldest (younger than 95 to older than $66 \mathrm{Ma}$ ) basement rocks: (1) flat trace-element patterns in oceanic basement of the Caribbean large igneous province (CLIP), (2) enriched OIB signatures in CLIP terranes, and (3) an arc signature in CLIP rocks. The mantle source involved in CLIP magmatism is related to the Galapagos plume. The change from intraplate CLIP magmatism occurred at ca. $66 \mathrm{Ma}$. The arc magmas generated between 66 and $42 \mathrm{Ma}$ were derived from a highly compositionally variable mantle source that ranged from highly depleted to somewhat less depleted in character, onto which a slab signature was imprinted. The 
"younger" arc magmatism that began at ca. $40 \mathrm{Ma}$, orientated from a relatively homogeneous, and slightly enriched mantle wedge. The changes observed in mantle sources for these Panamanian igneous rocks may be related to replacement of plume-mantle in the mantle wedge and/or homogenization by corner flow, and involvement of less depleted mantle material with time. Cessation of "normal" arc magmatism occurred around $5 \mathrm{Ma}$ as a result of the collision of the Cocos ridge in southeastern Costa Rica and cessation of convergence in Panama. The occurrence of HREE-depleted magmas in part of the arc-magmatic gap during the past 2 m.y. was the result of melting of the leading edge of subducting Cocos and Coiba Ridges at the margins of a slab window.

\subsection{REFERENCES}

Abratis, M., and Wörner, G., 2001, Ridge collision, slab-window formation, and the flux of Pacific asthenosphere into the Caribbean realm: Geology, v. 29, p. $12-$ 130.

Alvarado, G. E., Kussmaul, S., Chiesa, S., Gillot, P. Y., Appel, H., Wörner, G., and Rundle, C., 1992, Resumen cronoestratigrafico de las rocas igneas de Costa Rica basado en dataciones radiometricas: Translated Title: Chronostratigraphic review of igneous rocks of Costa Rica based on radiometric dates: Journal of South American Earth Sciences, v. 6, p. 151-168.

Buchs, D.M., Baumgartner, P.O., and Arculus, R., 2007, Late Cretaceous arc initiation on the edge of an oceanic plateau (Southern Central America). EOS trans. AGU, 88(52), FallMeet. Supl., Abstract T13C-1468.

Carr, M. J., Feigenson, M. D., and Bennett, E. A., 1990, Incompatible element and isotopic evidence for tectonic control of source mixing and melt extraction along the Central American arc: Contributions to Mineralogy and Petrology, v. 105, no. 4, p. 369-380.

Coates, A. G., Aubry, M. P., Berggren, W. A., and Collins, L. S., 2000, New evidence for the earliest stages in the rise of the Isthmus of Panama from Bocas del Toro, Panama: Geological Society of America, 2000 Annual Meeting, Abstracts with Programs, v. 32, p.146.

Collins, L. S., Coates, A. G., Berggren, W. A., Aubry, M. P., and Zhang J., 1996, The late Miocene Panama isthmian strait: Geology, v. 24: 687-690.

de Boer, J. Z., Defant, M. J., Stewart, R .H., Restrepo, J. F., Clark, L. F., Ramirez, A., 1988, Quaternary calc-alkaline volcanism in western Panama: Regional variation and implication fo tectonic framework: Journal of South American Earth Sciences, v. 1, p. 275-293.

de Boer, J. Z., Defant, M. J., Stewart, R. H., and Bellon, H., 1991, Evidence for active subduction below western Panama: Geology, v. 19, p. 649-652.

de Boer, J. Z. , Drummond, M. S., Bordelon, M. J ., Defant, M. J., Bellon, H., and Maury, R. C., 1995, Cenozoic magmatic phases of the Costa Rican island arc 
(Cordillera de Talamanca): in Mann P. (ed.) Geologic and tectonic development of the Caribbean plate boundary in Southern Central America Geological Society of America Special Paper 295, p. 35-55.

de Boer, J. Z., Drummond, M. S., Bordelon, M. J., Defant, M. J., Bellon, H., and Maury, R. C., 1995, Cenozoic magmatic phases of the Costa Rican island arc (Cordillera de Talamanca): in: Mann P. (ed.) Geologic and tectonic development of the Caribbean plate boundary in Southern Central America Geological Society of America Special Paper 295, p. 35-55.

Defant, M. J., Clark, L. F., Stewart, R. H., Drummond, M. S., de Boer, J. Z., Maury, R. C., Bellon, H., Jackson, T. E., and Restrepo, J. F., 1991a, Andesite and dacite genesis via contrasting processes: The geology and geochemistry of El Valle Volcano, Panama: Contributions to Mineralogy and Petrology, v. 106, p. 309324.

Defant, M. J., Richerson, P. M., de Boer, J. Z., Stewart, R. H., Maury, R. C., Bellon, H., Drummond, M. S., Feigenson, M. D., and Jackson, T. E., 1991b, Dacite genesis via both slab melting and differentiation: Petrogenesis of La Yeguada volcanic complex, Panama: Journal of Petrology, v. 32, p. 1101-1142.

Defant, M. J., Jackson, T. E., Drummond, M. S., De Boer, J. Z., Bellon, H., Feigenson, M. D., Maury, R. C., and Stewart, R. H., 1992, The geochemistry of young volcanism throughout western Panama and southeastern Costa Rica: an overview: Journal of the Geological Society, v. 149, no. 4, p. 569-579.

Drummond, M. S., Bordelon, M., de Boer, J. Z., Defant, M. J., Bellon, H., and Feigenson, M. D., 1995, Igneous petrogenesis and tectonic setting of plutonic and volcanic rocks of the Cordillera de Talamanca, Costa Rica-Panama, Central American arc: American Journal of Science, v. 295, p. 875-919.

Escalante, G., 1990, The geology of southern Central America and western Colombia: in Dengo, G. and Case, J. E. (eds.), The geology of North America: The Caribbean region, Geological Society of America, vol. H, p. 201-230.

Goossens, P. J., Rose, W. I., and Flores D., 1977, Geochemistry of tholeiites of the Basic Igneous Complex of northwestern South America: Geological Society America Bulletin, v. 88, p. 1711-1720.

Goss A. and Kay S. M., 2007, Steep REE patterns and enriched Pb isotopes in southern Central American arc magmas: Evidence for forearc subduction erosion?: Geochemistry, Geophysics, Geosstems, v. 7, Q05016, doi: 10.1029/2005GC001163

Harmon, R.S. (ed), 2005, The Rio Chagres, Panama, Multidisciplinary profile of a tropical watershed: Springer, Water Science and Technology Library, v. 52, p.1-355

Hauff, F., Hoernle, K., Schmincke, H.-U., Werner, R., 1997, A mid-Cretaceous origin for the Galapagos hotspot; volcanological, petrological and geochemical evidence from Costa Rican oceanic crustal segments: Geologisches Rundschau, v. 86, p.141-155.

Hauff, F., Hoernle, K., van der Bogaard, P., Alvarado, G., Garbe-Schoenberg, D., 2000, Age and geochemistry of basaltic complexes in western Costa Rica; contributions to the geotectonic evolution of Central America: Geochemistry, Geophysics, and Geosystems, v.1, 1009,.doi:10.1029/1999GC000020 
Haug, G.H., and Tiedemann, R., 1998, Effect of the formation of the Isthmus of Panama on Atlantic Ocean thermohaline circulation: Nature, v. 393, p. 673676.

Hoernle, K., Abt., D. L., Fischer, K.., M., Nichols, H., Hauff, V., Abers., G. a., v.d. Bogaard, P., Heydolph, K., Alvarado, G., Protti, M., Strauch, W., 2008, Arparallel flow in the mantle wedge beneath Costa Rica and Nicaragua: Nature, v. 451, 1094 - 1097.

Hoernle, K., Hauff, V., 2007, Oceanic Igneous Complexes. In Bundschuh, J., and Alvarado, G., (Eds.). Geology of Central America, Taylor \& Francis, Leiden, The Netherlands, p. 523-547.

Hoernle, K., Hauff, V., van der Bogaard, P., 2004, 70 m.y. history (139-69 Ma) for the Caribbean large igneous province: Geology, v. 32, p. 697-700.

Hoernle, K., van der Bogaard, P., Werner, R., Lissinna, B., Hauff, V., Allvarado, G., and Garbe-Schönberg, D., 2002, Missing history (16-71 Ma) of the Galapagos hotspot: Implications for the tectonic and biological evolution of the Americas: Geology, v. 30, p. 795-798.

Johnston, S. T., and Thorkelson, D .J., 1997, Cocos-Nazca slab window beneath Central America: Earth and Planetary Science Letters, v. 146, p. 465-474.

Kay, S.M., Ramos, V. A., and Marquez, M., 1993, Evidence in Cerro Pampa volcanic rocks for slab-melting prior to ridge-trench collision in southern South America: Journal of Geology, v. 101, p. 703-714.

Kesler, S. E., Sutter, J. F., Issigonis, M. J., Jones, L. M., and Walker, R. L., 1977, Evolution of porphyry copper mineralization in an oceanic island arc; Panama: Economic Geology, v. 72, no. 6, p. 1142-1153.

Krawinkel, H., Seyfried, H., Calvo, C., and Astorga, A., 2000, Origin and inversion of sedimentary basins in Southern Central America: Zeitschrift für Angewandte Geologie, Sonderheft, v. 1, p. 71-77.

Lonsdale, P., 2005, Creation of the Cocos and Nazca plates by fission of the Farallon Plate: Tectonophysics, v. 404; 3-4,p. 237-264.

Lonsdale, P., and Klitgord, K. D., 1978, Structure and tectonic history of the eastern Panama Basin: Geological Society of America Bulletin, v. 89, no. 7, p. 981999.

Mann, P. and Kolarsky, R. A., 1995, East Panama deformed belt; structure, age, and neotectonic significance: in Mann P. (ed.) Geologic and tectonic development of the Caribbean plate boundary in Southern Central America Geological Society of America, Special Paper 295, p. 111-130.

Maury, R. C., Defant, M. J., Bellon, H., deBoer, J. Z., Stewart, R. W., and Cotten, J., 1995, Early Tertiary arc volcanics from eastern Panama: in Mann P. (ed.) Geologic and tectonic development of the Caribbean plate boundary in Southern Central America, Geological Society of America Special Paper 295, p. 29-34.

Meschede, M, and Barckhausen, U, 2001, The relationship of the Cocos and Carnegie ridges: age constraints from paleogeographic reconstructions: International Journal of Earth Science, v. 90, p, 386-392. 
Pindell, J. L. and Barret, S. F., 1990. Geological evolution of the Caribbean regions: A plate tectonic perspective: in Dengo, G., and Case, J. E. (eds.), Geology of North America, The Caribbean regions: Geological Society of America, v. H, p. 405-432.

Pindell, J. L., Kennan, L., Maresch, W.V., Stanek, K. P., Draper, G., and Higgs, R., 2005, Plate-kinematics and crustal dynamics of circum-Caribbean arccontinent interactions: Tectonic controls on basin development in ProtoCaribbean margins: in Ave Lallemant H. G., Sisson V. B. (eds.), CaribbeanSouth American plate interactions, Venezuela. Boulder, Geological Society of America Special Paper 394, p. 7-52.

Pindell, J., Kennan, L., Stanek, K. P., Maresch, W. V., and Draper, G., 2006, Foundations of Gulf of Mexico and Caribbean evolution: eight controversies resolved. Geological Acta, v. 4, p. 303-341.

Reynaud, C., Jaillard, E., Lapierre, H., Mamberti, M., Mascle, G. H., 1999, Oceanic plateau and island arcs of southwestern Ecuador; their place in the geodynamic evolution of northwestern South America: Tectonophysics, v. 307; 3-4, p. $235-$ 254.

Silver, E., Costa-Pisani, P., Hutnak, M., Fisher, A., DeShon, H., Taylor, B., 2004, An 8-10 Ma tectonic event on the Cocos Plate offshore Costa Rica; results of Cocos Ridge collision? ,Geophysical Research Letters, v. 31; 18.

Sinton, C. W., Duncan, R. A., and Denyer, P., 1997, Nicoya Peninsula, Costa Rica: A single suite of Caribbean oceanic plateau magmas: Journal of Geophysical Research, v. 102, p. 15507 - 15520.

Sinton, C. W., Duncan, R. A., Storey, M., Lewis, J., and Estrada, J. J., 1998, An oceanic flood basalt province within the Caribbean plate: Earth and Planetary Science Letters, v. 155, p. 221-235.

Sun, S. S., and McDonough, W. F., 1989, Chemical and isotopic systematics of oceanic basalts: Implications for mantle composition and processes: in Saunders, A. D. and Norry, M. J. (eds.) Magmatsim in the ocean basins, Geological Society of London Special Publication, v. 42, p. 313-345.

Thompson, P. M. E., Kempton, P. D., White, R. V., Kerr, A. C., Tarney, J., Saunders, A. D., Fitton, J. G., and McBirney, A., 2004, Hf-Nd isotope constraints on the origin of the Cretaceous Caribbean plateau and its relationship to the Galapagos plume: Earth and Planetary Science Letters, v. 217, p. 59-75.

Thorkelson, D. J., and Breitsprecher, K., 2005, Partial melting of slab window margins: genesis of adakitic and non-adakitic magmas. Lithos, v. 79, p. 254von Eynatten, H., Krawinkel, H., and Winsemann, J., 1993, Plio-Pleistocene outer arc basins in southern Central America: in Frostick, L.E., and Steel, R.J., eds., Tectonic controls and signatures in sedimentary successions: International Association of Sedimentologists Special Publication 20, p. 399414.

von Eynatten, H., Krawinkel, H. \& Winsemann, J., 1993, Plio-Pleistocene outer arc basins in Southern Central America (Osa Peninsula, Costa Rica). Internatonal Association of Sedimentologists Special Publications, 20, p. 399-414. 
v. Huene, R., and Scholl, D. W., 1991, Observations at convergent margins concerning sediment subduction, subduction erosion, and the growth of continental crust. Reviews of Geophysics, v. 29, p. 279-316.

Wörner, G., Harmon, R. S., Wegner, W., Singer, B., 2006, Linking Americas Backbone: Geological development and basement rocks of Central Panama: Geological Society of America Conference Backbone of the Americas, Mendoza April 3-7, 2006, Geological Society of America Speciality Meeting Abstracts with Programs, p. 60. 


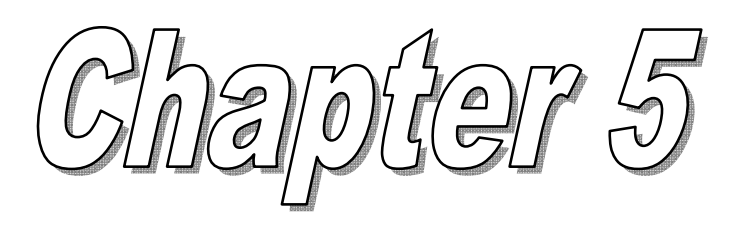

\section{Magmatic history and evolution of the Central American Land Bridge in Panama since Cretaceous times}

Wencke Wegner ${ }^{1}$, Gerhard Wörner ${ }^{1}$, Russell S. Harmon ${ }^{2}$, Brian R. Jicha ${ }^{3}$

${ }^{1}$ Division of Geochemistry, Geosciences Center, University of Göttingen, 37077 Göttingen, Germany

${ }^{2}$ USARL Army Research Office, Durham, NC 27703 USA and Department of Marine, Earth, and Atmospheric Sciences, North Carolina State University, Raleigh, NC 27695 USA ${ }^{3}$ Department of Geology \& Geophysics, University of Wisconsin, Madison, WI 53706 USA

GSA Bulletin v. 123; no. 3-4; p. 703-724 


\subsection{ABSTRACT}

Chemical compositions for 310 igneous rocks from the Cordillera de Panama and the Soná and Azuero Peninsulas were supplemented by ${ }^{40} \mathrm{Ar} /{ }^{39} \mathrm{Ar}$ dating and $\mathrm{Sr}-, \mathrm{Nd}-$, $\mathrm{Pb}$-, and $\mathrm{O}$-isotope analysis to determine the magmatic evolution and oceanic plate interactions over the last $100 \mathrm{Ma}$ in western Panama. An initial phase of intraplate magmatism, having geochemical characteristics of the Galápagos hotspot, formed the oceanic basement of the Caribbean large igneous plateau (CLIP) from 139 to 69Ma. Younger accreted terranes with enriched trace element patterns (accreted ocean island basalt [OIB]) were amalgamated between 70-20 Ma. A second magmatic phase in the Azuero and Soná Peninsulas has trace element patterns (Soná-Azuero arc) suggesting the initiation of subduction at 71 to $69 \mathrm{Ma}$. Arc magmatism continued in the Chagres basin region (Chagres-Bayano arc) from 68 to $40 \mathrm{Ma}$. A third phase formed discrete volcanic centers across the Cordillera de Panama (Cordilleran arc) from 19 to $5 \mathrm{Ma}$. The youngest phase consists of isolated volcanic centers of adakitic composition (Adakite suite) in the Cordillera de Panama that developed over the last two million years. Initiation of arc magmatism at $71 \mathrm{Ma}$ coincides with the cessation of Galápagos plateauformation, suggesting a causal link. The transition from intraplate to arc magmatism occurred relatively quickly and introduced a new enriched mantle source. The arc magmatism involved progressive transition to more homogeneous intermediate mantle wedge compositions through mixing and homogenization of subarc magma sources through time and/or the replacement of the mantle wedge by a homogeneous, relatively undeleted asthenospheric mantle. Adakite volcanism started after a magmatic gap, enabled by the formation of a slab window.

\subsection{INTRODUCTION AND GEOLOGICAL SETTING}

The Central American Land Bridge (Fig. 5.1) is located between Nicaragua and northern Columbia and occupies a critical position connecting the continents of North America and South America. Its formation around 3 million years ago (Coates et al., 2000, 1992) was a consequence of Caribbean regional tectonics possibly combined with interaction of the paleo-Galápagos hotspot tracks with the Central American subduction zone (Hoernle et al. 2002) and had significant effects on marine and terrestrial faunal distributions and global oceanic circulation patterns (Duque-Caro, 1990; Coates et al., 1992; Collins et al. 1996; Haug and Tiedemann, 1998). 


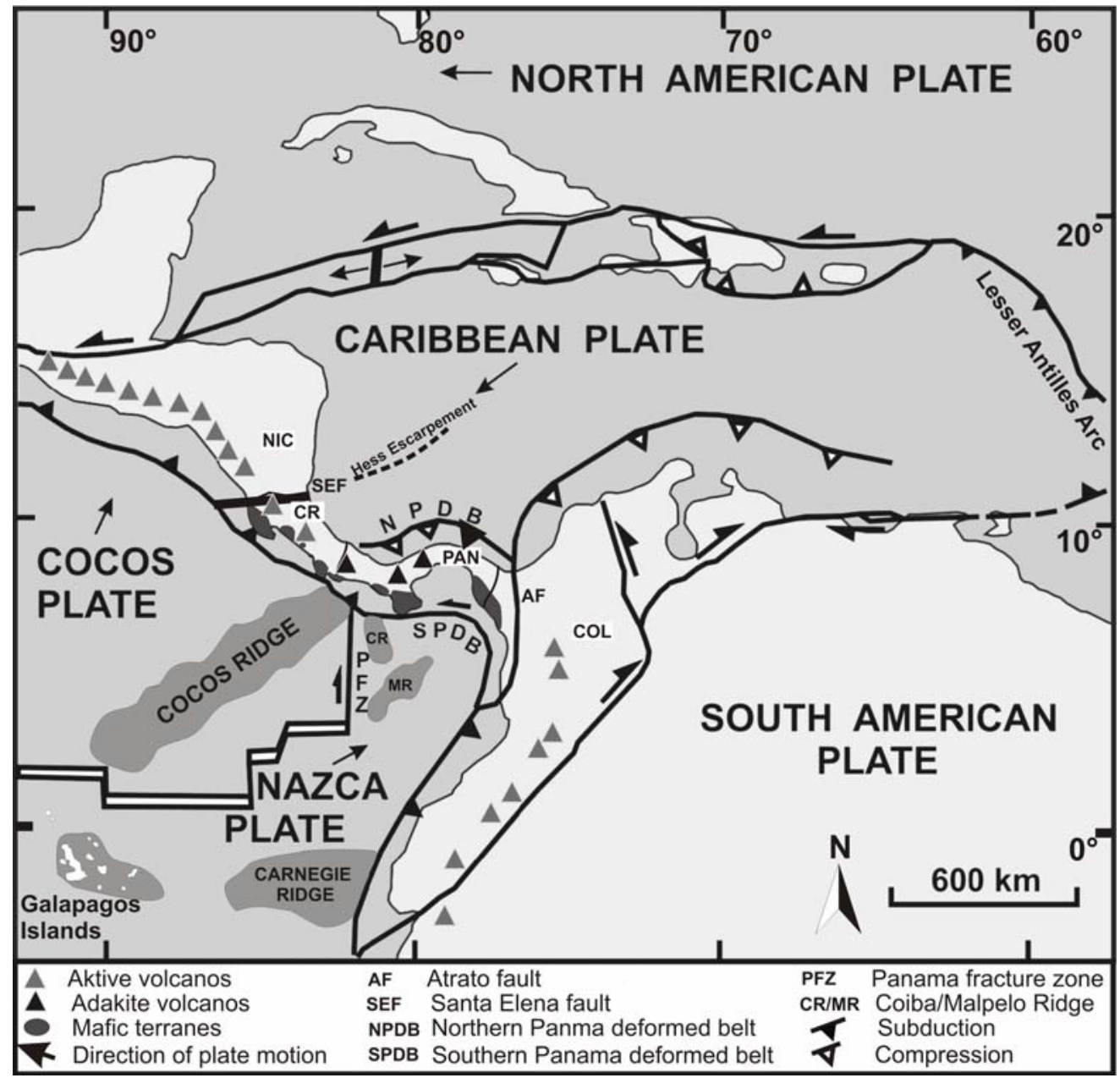

Figure 5.1. Tectonic setting of the Central America Land Bridge region (after Meschede and Frisch 1998). Abbrevaitions are as follows COL-Colombia, CR-Costa Rica, NIC-Nicaragua, PAN-Panama.

The plate tectonic history of the region has been reviewed by Pindell et al. (2006), who postulate a Pacific origin of the Caribbean plate and significant displacement since Cretaceous time relative to the westward-moving North American and South American plates. Arc magmatism, together with high-P/low-T metamorphic rocks, dates the onset of westward-dipping subduction at the eastern margin of the Caribbean plate that resulted from a relative eastward movement of the Pacific region at 125 to $113 \mathrm{Ma}$ (Pindell et al., 2005; 2006). An Aleutian-style transcurrent plate boundary at the eastern margin of the Pacific (Farrallon) plate was converted into a west-facing subduction zone that subsequently changed to be east-facing during Aptian time. The initial Greater Antilles arc and the present Lesser Antilles subduction zone was a consequence of this convergence at the eastern margin of the Caribbean plate. The western plate margin may have been inactive until the time 
when eastward facing subduction commenced between the Pacific and Caribbean plates, probably by Late Albian time (c. $95 \mathrm{Ma}$; Pindell et al., 2006). The origin and the role of the thickened Caribbean plateau have been much debated. Some authors (e.g. Duncan and Hargraves, 1984) have suggested that the plateau formed as a result of the arrival of the Galápagos plume below the Pacific plate and subsequent development of the Carribean Large Igneous Province (CLIP) on Jurassic oceanic crust. This over-thickened crust caused choking of Pacific subduction and initiated the west-facing subduction (e.g., Kerr et al., 2002; Hauff et al., 1997, 2000a). Pindell et al. $(2005,2006)$, however, argued that an age of 92 to $88 \mathrm{Ma}$ for rocks of the Caribbean plateau is inconsistent with older high-P/low-T rocks that suggest an earlier subduction reversal. However, Hoernle et al. (2004) published six Ar-Ar ages for CLIP rocks from the Nicoya Peninsula in the range of 139 to $110 \mathrm{Ma}$ that would permit an older age for the plateau, thus reviving the idea of a possible link between Galápagos and CLIP. This result opens the possibility that plateau formation began at this early time, caused the subduction reversal at $110 \mathrm{Ma}$ (Pindell et al., 2005), and then continued to develop until $\sim 69$ Ma (Hoernle et al., 2004) well after the initiation of convergence on its eastern margin.

The geochemical composition and the age (139 to $69 \mathrm{Ma}$, Hoernle et al. 2004) of the CLIP mafic complexes along the Central American Land Bridge between the Santa Elena transform fault (i.e., the southern tectonic border to the Chortis continental block that contained present-day Guatemala, Honduras, and most of Nicaragua) in the north and the Atrato fault (the continuation of the south Caribbean fault along the northern margin of South America) in the south, have been taken as evidence of the important role of the Galápagos hotspot for the development of the Central American Land Bridge (Hauff et al., 2000a, 2000b; Hoernle et al., 2002). These mafic terranes either comprise a major part of the Central American crust or are fragments amalgamated tectonically to the Chortis block (Goossens et al., 1977; Reynaud et al., 1999). However, the link between the Galápagos hotspot and these terranes remains disputed. Pindell et al. (2006) argue, based on absolute plate motion reconstruction, that linking Galápagos to these terranes would require migration of the Galápagos hot spot some $1000 \mathrm{~km}$ within in the fixed mantle reference frame. Therefore, the tectonic history of the western margin of Caribbean plate requires continued investigation. 
Magmatic rocks in Panama and Costa Rica have been formed by subduction zone volcanism since early Tertiary time (64 or $61 \mathrm{Ma}$, Maury et al. [1995] and Lissinna et al. [2006], respectively). A broad temporal change in magma compositions from tholeiitic to (low-K) calc-alkaline has been observed beginning in the Oligocene (since $>30 \mathrm{Ma}$ ) by Alvarado et al. (1992); de Boer et al. (1995), and Abratis and Wörner (2001). This change continued from low-K ckalc-alkaline toward high-K-calcalkaline compositions, which started between the middle to late Miocene (Gazel et al. 2009). During this time, additional ocean islad basalt (OIB)-type basalt complexes, derived from seamounts related to the Galápagos hotspot, were accreted to the continental margin until $\sim 16$ Ma (Alvarado et al., 1992; Hauff et al. 1997, 2000a; Hoernle et al., 2002). Typical arc volcanism in southern Costa Rica and western Panama ceased during the upper Miocene due to the collision of the Cocos Ridge with the Chortis block. This collision took place at 2-3 Ma (MacMillan et al., 2004). This was followed by a 2-3 million year gap in magmatic activity. At the same time, spreading ceased in the Panama basin (Lonsdale and Klitgord, 1978) and subduction also stopped on the Pacific coast of eastern and central Panama, but continued plate convergence was accommodated by movements in the N-S striking Panama fracture zone and the eastern and northern Panama deformed belt (Mann and Kolarsky, 1995). The progressive closure of the oceanic connection between the Caribbean Sea and Pacific Ocean occurred during the interval between 6.2 and 3.5 Ma (DuqueCaro, 1990; Coates et al., 1992; Collins et al., 1996; Haug et al., 2001; Coates et al., 2000) as a consequence of terrane collision, magmatism, and tectonic uplift (Hoernle et al. 2002, de Boer et al. 1995) along transverse fault systems in present-day central Panama. Subsequently, volcanism of adakitic composition was initiated in western Panama and southern Costa Rica at $\sim 2$ Ma (Defant et al., 1991a, 1991b; Johnston and Torkelson, 1997; Wörner and Abratis, 2001); its source and petrogenesis remain controversial.

Previous geochemical studies on volcanic rocks of the Central American Land Bridge region have focused on three main issues: (1) the origin of the mafic (Caribbean large igneous province and "younger") complexes (Goossens et al., 1977; Hauff et al., 1997, 2000a; Hoernle et al. 2002, 2004 and references therein; Hoernle and Hauff, 2007), (2) the subsequent evolution of Paleocene-Miocene age rocks on the western Caribbean margin having a volcanic arc affinity and (3) the tectonic context and origin of Quaternary volcanic centers in western Panama and Costa Rica (de 
Boer et al., 1988, 1995; Defant et al.,1991a, 1991b; Drummond et al., 1995; Abratis and Wörner, 2001; Carr et al., 2003). However, the link between the Caribbean large igneous province basement and the volcanic arc setting, i.e. Paleocene to Miocene volcanism, has received relatively little attention (de Boer et al., 1988, 1995) due to limited exposure and difficult access to the Central American Cordillera.

Based on existing data related to the magmatic history of southern Central America, this study fills an important knowledge gap by providing new high-resolution ${ }^{40} \mathrm{Ar} /{ }^{39} \mathrm{Ar}$ dates, major and trace element analyzes, and $\mathrm{Nd}-, \mathrm{Sr}-, \mathrm{Pb}-$, and O-isotope ratios for a large suite of volcanic and intrusive rocks from western and central Panama that document the magmatic history and petrogenetic evolution of the Central American Land Bridge region over the past 71 million years. This study examines the temporal evolution of magma compositions and variations in associated magma sources during this period and discusses the tectonic processes which led to these changes.

\subsection{SAMPLE COLLECTION AND ANALYTICAL METHODS}

Figure 5.2 shows the geographic locations of the samples analyzed. The study area extends over an E-W distance of $\sim 500 \mathrm{~km}$ across the Central Cordillera of Panama from the Lake Bayano region in the east to the Costa Rican border in the west (Fig. 5.2). Samples were also collected in a NW-SE traverse along the Panama Canal, throughout the Upper Rio Chagres region northeast of the Panama Canal, and from the Azuero and Soná peninsulas in southern Panama. The majority of the samples are volcanic and plutonic rocks of Upper Cretaceous to Quaternary age, but also include some samples from the Cretaceous basement. The samples are divided into six geographic-temporal groups (Caribbean large igneous province, accreted OIB, Soná-Azuero arc, Chagres-Bayano arc, Cordilleran arc, and Adakite suite) on the basis of age, spatial distribution and trace element characteristics (see discussion that follows). Only the freshest rocks were sampled in the field. However, many samples exhibited minor but noticeable degrees of alteration. 310 samples were selected for geochemical analysis at the Geosciences Center at the University of Göttingen by X-ray fluorescence spectroscopy (XRF) and inductively coupled plasma mass spectrometry (ICP-MS). Based on mineral content, lithology, and presumed age from geological field relations, subsets of 40 samples (rocks and separated dated minerals) were selected for determination of isotopic composition $\left({ }^{87} \mathrm{Sr} /{ }^{86} \mathrm{Sr}\right.$, ${ }^{143} \mathrm{Nd} /{ }^{144} \mathrm{Nd},{ }^{206} \mathrm{~Pb} /{ }^{204} \mathrm{~Pb},{ }^{207} \mathrm{~Pb} /{ }^{204} \mathrm{~Pb},{ }^{208} \mathrm{~Pb} /{ }^{204} \mathrm{~Pb}$ and ${ }^{18} \mathrm{O} /{ }^{16} \mathrm{O}$ ratios) representing all 
lithologies and age groups. Separated clean, acid-etched minerals (amphiboles, Kfeldspars and pyroxenes) were used for isotope analysis rather than whole rocks because clean minerals record magmatic values and should be less affected by alteration processes.
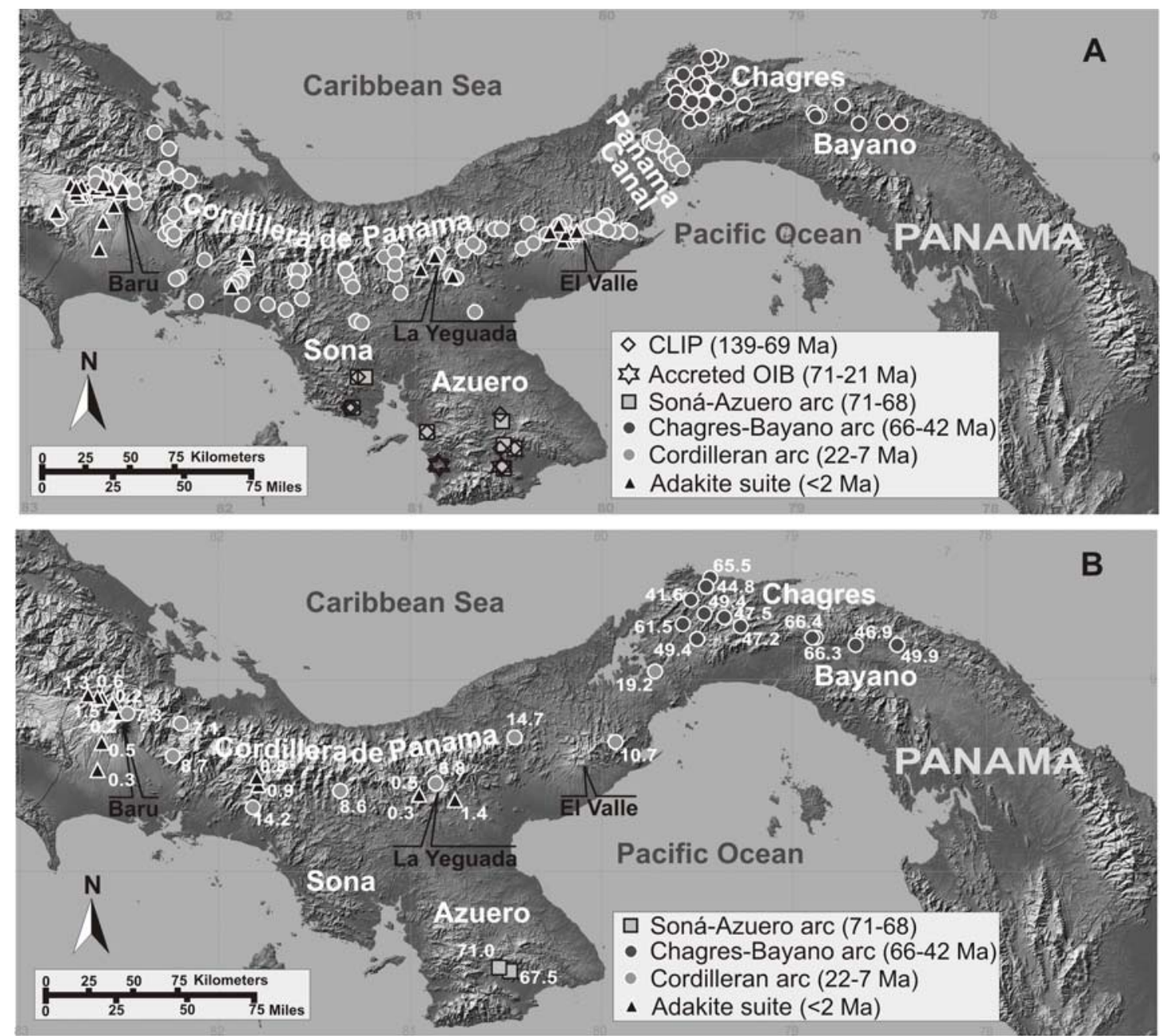

Figure 5.2. Topographic map of Panama showing the locations and volcanic features referred to in the text and the geographic distribution of the samples (A: all samples studied, B: only dated samples with labelled ages) collected for this study. The symbols (explained in the figure) represent the different arc groups sampled sampled.

Based on mineral content, lithology, and presumed age from geological field relations, subsets of 40 samples (rocks and separated dated minerals) were selected for determination of isotopic composition $\left({ }^{87} \mathrm{Sr} /{ }^{86} \mathrm{Sr},{ }^{143} \mathrm{Nd} /{ }^{144} \mathrm{Nd},{ }^{206} \mathrm{~Pb} /{ }^{204} \mathrm{~Pb}\right.$, ${ }^{207} \mathrm{~Pb} /{ }^{204} \mathrm{~Pb},{ }^{208} \mathrm{~Pb} /{ }^{204} \mathrm{~Pb}$ and ${ }^{18} \mathrm{O} /{ }^{16} \mathrm{O}$ ratios) representing all lithologies and age groups. Separated clean, acid-etched minerals (amphiboles, K-feldspars and pyroxenes) were used for isotope analysis rather than whole rocks because clean 
minerals record magmatic values and should be less affected by alteration processes. Of these same minerals 35 were also used for age dating by the highprecision ${ }^{40} \mathrm{Ar} /{ }^{39} \mathrm{Ar}$ method at the University of Wisconsin-Madison Rare Gas Geochronology Laboratory. As a consequence of strong secondary alteration of rocks from the Soná-Azuero arc, only two samples from this group were suitable for isotopic analysis, whereas 14, 10, and 14 samples from the Chagres-Bayano arc, Cordilleran arc, and Adakite suite groups, respectively, were analyzed for isotopic composition.

Concentrations of major and minor elements ( $\mathrm{Si}, \mathrm{Ti}, \mathrm{Al}, \mathrm{Fe}, \mathrm{Mn}, \mathrm{Mg}, \mathrm{Ca}, \mathrm{Na}, \mathrm{K}$, and $\mathrm{P}$ ) as well as selected trace elements ( $\mathrm{Nb}, \mathrm{Zr}, \mathrm{Y}, \mathrm{Sr}, \mathrm{Rb}, \mathrm{Ga}, \mathrm{Zn}, \mathrm{Cu}, \mathrm{Ni}, \mathrm{Co}, \mathrm{Cr}, \mathrm{V}$, $\mathrm{Ba}$, andSc) were analyzed by XRF on glass fusion discs on a PANalytical AXIOS Xray fluorescence spectrometer. About 50 reference materials from the U.S. Geological Survey; the International Working Group on Analytical Standards of Minerals, Ores and Rocks; the National Research Council of Canada; the Geological Survey of Japan; the South African Bureau of Standards; and the U.S. National Institute of Standards and Technology (NIST) were used for the major and trace element calibration. For major element analyzes, analytical precision is better than $1 \%-2 \%$; for trace element determinations standard deviations of consecutive analyzes are in the range of $2 \%$ to $5 \%$ relative at the level of $20-30 \mathrm{ppm}$. Detection limits vary from 3 to $0.5 \mathrm{ppm}$ for the majority of the measured elements.

Rare-earth elements (REE; La to Lu), high-field-strength elements (HFSE; Nb, Ta, Zr, and $\mathrm{Hf}$ ), large-ion-lithophile elements ( $\mathrm{Rb}, \mathrm{Sr}, \mathrm{Ba}$, and $\mathrm{Cs}$ ) and a group of other trace elements ( $\mathrm{Li}, \mathrm{Sc}, \mathrm{Cu}, \mathrm{V}, \mathrm{Cr}, \mathrm{Co}, \mathrm{Ni}, \mathrm{Zn}, \mathrm{Y}, \mathrm{Pb}$, Th, and $\mathrm{U}$ ), were measured using a Perkin Elmer ELAN DRCII ICPMS. Sample solutions were prepared following an approach modified from Heinrichs and Herrmann (1990) and diluted to 1:1000 with $20 \mathrm{ppb} \mathrm{Ge}, \mathrm{Rh}, \mathrm{Re}$, and In as internal standards. Based on co-processing the laboratory internal standards and the international standards JB-3 and JA-2 as unknown samples, the $2 \sigma$ error of the analytical method was estimated to be $<20 \%$ for $\mathrm{Nb}$ and $\mathrm{Ta},<10 \%$ for $\mathrm{Be}, \mathrm{Cs}, \mathrm{Cu}, \mathrm{Hf}, \mathrm{Li}, \mathrm{Y}, \mathrm{Rb}, \mathrm{Pb}, \mathrm{Tl}$, Th and $\mathrm{U}$ and $\sim 5 \%$ for the REE.

Isotope ratios of ${ }^{87} \mathrm{Sr} /{ }^{86} \mathrm{Sr},{ }^{143} \mathrm{Nd} /{ }^{144} \mathrm{Nd},{ }^{206} \mathrm{~Pb} /{ }^{204} \mathrm{~Pb},{ }^{207} \mathrm{~Pb} /{ }^{204} \mathrm{~Pb}$, and ${ }^{208} \mathrm{~Pb} /{ }^{204} \mathrm{~Pb}$ were measured using a Finnigan TRITON TI thermal ionization mass spectrometer (TIMS). For $\mathrm{Sr}-, \mathrm{Nd}-$, and $\mathrm{Pb}$-isotope ratio determinations, $30 \mathrm{mg}$ of hand-picked feldspar and $50 \mathrm{mg}$ of amphibole were leached with $1 \mathrm{ml}$ of $0.18 \mathrm{~N} \mathrm{HCl}$ at $50{ }^{\circ} \mathrm{C}$ and $100{ }^{\circ} \mathrm{C}$, each 
for $15 \mathrm{~min}$ and dissolved in $4 \mathrm{ml}$ of $\mathrm{HF}: \mathrm{HNO}_{3}$ (1:1) for $24 \mathrm{~h}$ at $200{ }^{\circ} \mathrm{C}$ in Savillex beakers inside a pressure vessel. For Sr separation we used columns containing BIORAD AG 50W-X8, 200-400 mesh ion exchange resin. For Nd separation, the REE fraction of the first separation step was separated in a second set of columns filled with Teflon powder impregnated with ion-exchanging HDEHP bis-(2-etylhexy)phosphate. For TIMS measurements, the separated $\mathrm{Sr}$ and $\mathrm{Nd}$ was dissolved in $3 \mu \mathrm{I}$ $\mathrm{HNO}_{3}$ and $3 \mu \mathrm{H}_{3} \mathrm{PO}_{4}$ and loaded on Re double filaments $(\sim 1 \mu \mathrm{g})$. Measured Sr- and Nd-isotope ratios were corrected for mass fractionation to ${ }^{86} \mathrm{Sr} /{ }^{88} \mathrm{Sr}=0.1194$ and ${ }^{146} \mathrm{Nd} /{ }^{144} \mathrm{Nd}=0.7219$ and normalized to values for the NISTstandard reference materials (SRMs) $\left({ }^{87} \mathrm{Sr} /{ }^{86} \mathrm{Sr}=0.710245\right)$, and La Jolla $\left({ }^{143} \mathrm{Nd} /{ }^{144} \mathrm{Nd}=0.511847\right)$ standards. Measured values of these standards over the period of the study were ${ }^{87} \mathrm{Sr} /{ }^{86} \mathrm{Sr}=0.710258 \pm 7$ (10 analyses) and ${ }^{143} \mathrm{Nd} /{ }^{144} \mathrm{Nd}=0.511848 \pm 5$ (10 analyses). External $2 \sigma$ errors are estimated at $<0.001 \%$ for $\mathrm{Sr}$ and $\mathrm{Nd}$. The total blank for $\mathrm{Sr}$ was $261 \mathrm{pg}$ and for $\mathrm{Nd} 135 \mathrm{pg}$ and thus considered negligible. For $\mathrm{Pb}$-isotope analysis, separation $\sim 100 \mathrm{mg}$ of leached minerals were dissolved in $4 \mathrm{ml} \mathrm{HF: \textrm {HNO } _ { 3 }}$ $(1: 1)$ in Savillex pressure vessels at $200{ }^{\circ} \mathrm{C}$ for at least $12 \mathrm{~h}$. After pressure digestion and evaporation, the samples were dissolved twice in $1 \mathrm{ml} 0.5 \mathrm{~N} \mathrm{HBr}$ and centrifuged. $\mathrm{Pb}$ was separated on anion exchange columns containing resin (Biorad AG1-X8, 200-400 mesh). The $\mathrm{Pb}$ fraction was mounted on Re single filament using $3 \mu \mathrm{HNO}_{3}$ and $3 \mu \mathrm{l}$ silica-gel. Ionization temperature for $\mathrm{Pb}$ measurement was held constant between 1150 and $1300{ }^{\circ} \mathrm{C}$ and controlled by an optical temperature-reader. Measured $\mathrm{Pb}$-isotope ratios were corrected to NIST SRM-981 using a mass fractionation factor of $0.069 \%$ for ${ }^{206} \mathrm{~Pb} /{ }^{204} \mathrm{~Pb}, 0.077 \%$ for ${ }^{207} \mathrm{~Pb} /{ }^{204} \mathrm{~Pb}$ and $0.049 \%$ for ${ }^{208} \mathrm{~Pb} /{ }^{204} \mathrm{~Pb}$. Thirteen standard measurements gave means of ${ }^{206} \mathrm{~Pb} /{ }^{204} \mathrm{~Pb}=$ $16.92 \pm 0.01,{ }^{207} \mathrm{~Pb} /{ }^{204} \mathrm{~Pb}=15.47 \pm 0.01$, and ${ }^{208} \mathrm{~Pb} /{ }^{204} \mathrm{~Pb}=36.73 \pm 0.03$. The total error $(2 \sigma)$ was $<0.1 \%$. The total blank for $\mathrm{Pb}$ was $500 \mathrm{pg}$.

${ }^{18} \mathrm{O} /{ }^{16} \mathrm{O}$ ratios were determined on one to three grains $(\sim 1 \mathrm{mg})$ of amphibole, pyroxene or feldspar using a Thermo MAT 253 dual-inlet, gassource mass spectrometer. The gas extraction line used is similar to that described by Sharp (1990) except that $F_{2}$ is used for fluorination instead of $\mathrm{BrF}_{5}$ and that $\mathrm{O}_{2}$ is measured directly and not reacted to $\mathrm{CO}_{2}$. Twelve samples and four standards were loaded into a Ni sample holder and evacuated overnight. The samples were heated $\left(>2000{ }^{\circ} \mathrm{C}\right)$ by a $\mathrm{CO}_{2}$-laser in an atmosphere of $\mathrm{F}_{2}$, liberating molecular oxygen and forming residual fluorides. Excess $\mathrm{F}_{2}$ was then removed by reaction with $\mathrm{NaCl}$ at $\sim 150{ }^{\circ} \mathrm{C}$ to 
form $\mathrm{NaF}$ and any $\mathrm{Cl}_{2}$ produced was collected in two liquid nitrogen traps at $-196{ }^{\circ} \mathrm{C}$. Finally, purified $\mathrm{O}_{2}$ was trapped on a molecular sieve at $-196{ }^{\circ} \mathrm{C}$ and the $\mathrm{O}_{2}$ then expanded into the mass spectrometer inlet system for the simultaneous analysis of masses 32,33 , and 34 by heating the molecular sieve to $\sim 80^{\circ} \mathrm{C}$. The sample gas is compared to a reference $\mathrm{O}_{2}$ of known $\delta^{18} \mathrm{O}_{\text {vsmow (Vienna standard mean ocean }}$ water) of $+12.5 \%$ to determine its O-isotopic composition. For further details see Pack et al. (2007). Measured $\delta{ }^{18} \mathrm{O}$ values were corrected for machine drift by normalization to measured standards (National Bueau of Standerds [NBS] 28 quartz, San Carlos olivine, UWG-2 garnet).

Incremental heating experiments for ${ }^{40} \mathrm{Ar} /{ }^{39} \mathrm{Ar}$ analysis were performed on amphibole, K-feldspar, plagioclase crystals, and matrix material in the Rare Gas Geochronology Laboratory at the University of Wisconsin-Madison using a defocused $25 \mathrm{~W} \mathrm{CO}_{2}$ laser. Individual grains were analyzed from four samples, but in most cases, multicrystal aliquots $(\sim 10 \mathrm{mg})$ were lased to yield sufficient argon for analysis. Prior to each laser step-heating experiment, samples were pre-degassed at $2.0 \%$ power $(0.06 \mathrm{~W})$ to remove potentially large amounts of water and atmospheric argon. Very little ${ }^{39} \mathrm{Ar}\left(<0.1 \%\right.$ of total ${ }^{39} \mathrm{Ar}$ in the sample) is released during this pre-heating procedure. Experiments yielded largely concordant age spectra with 4-10 steps comprising $>82 \%$ of the gas released. Isotopic analyses and data reduction followed the procedures of Smith et al. (2006). Details of the method and results are given in the appendix (complete Ar-results)

\subsection{RESULTS AND DISCUSSION}

The results of the 310 chemical analyses and their locations are given in the appendix (full data table and sample regions Panama). Our Caribbean large igneous province and accreted OIB groups were defined based on regional geology and similarities to published trace element data (Hauff et al., 2000a, Hoernle et al., 2002). The other groups are defined on the basis of stratigraphy and field morphology of sampled units, together with petrology and spatial vicinity of the dated samples of the same group. To ensure that our sample grouping indeed represents mostly time rather than only regional geographic distribution, dated and undated samples of different groups were compared for chemical and isotopic similarities. The withingroup consistency is much higher than the intergroup consistency of neighboring samples. 


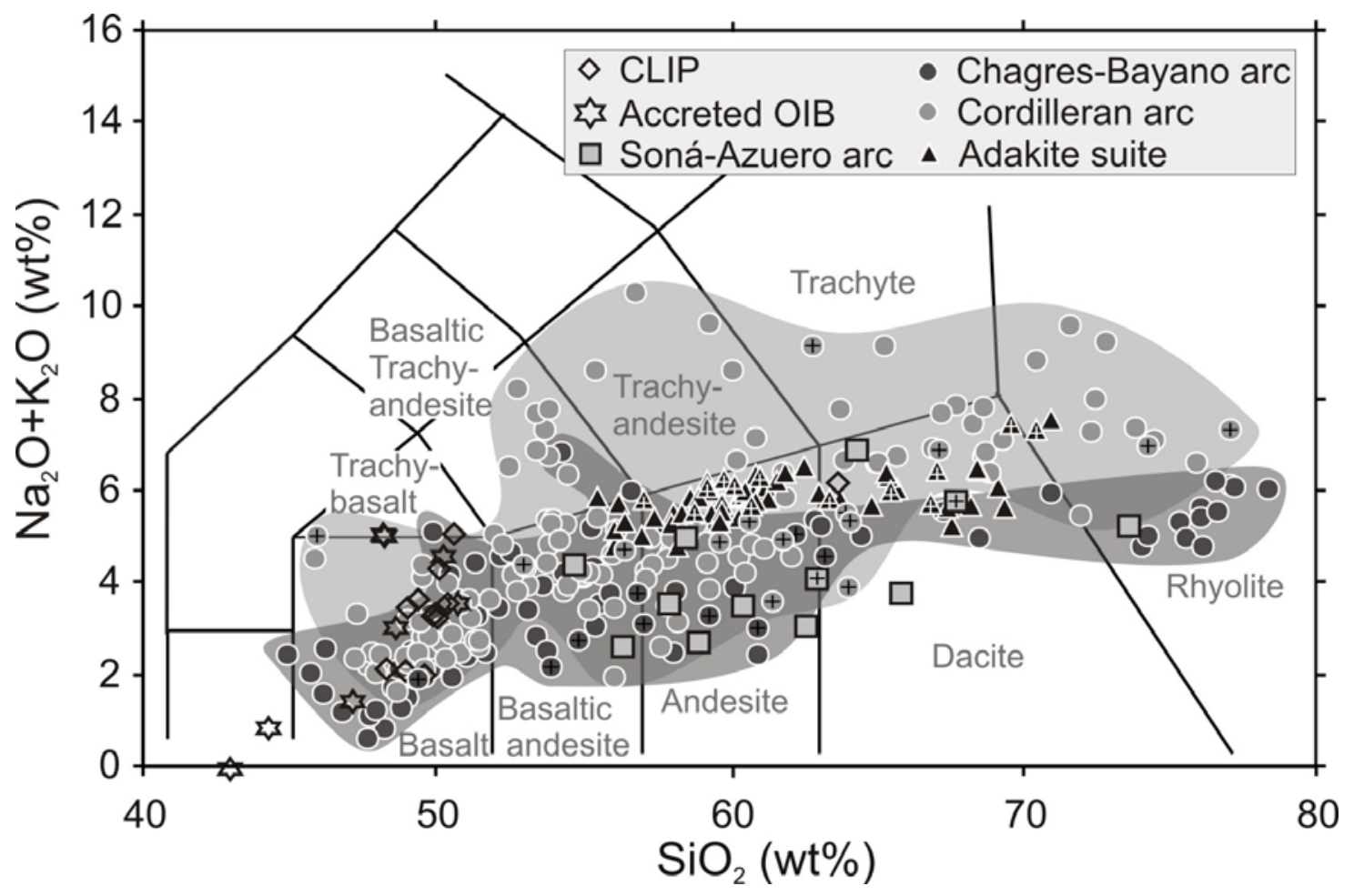

Figure 5.3. Chemical classification and nomenclature of volcanic rocks displayed in total alkali versus silica (TAS) diagram according Le Maitre et al. (1989). Shaded areas highlight the two largest arc groups: dark grey for Chagres-Bayano arc and light grey for Cordilleran arc. Samples for which ${ }^{40} \mathrm{Ar}{ }^{39} \mathrm{Ar}$ ages were obtained are denoted with crosses. CLIP-Caribbean large igneous province; OIB-ocean island basalt.

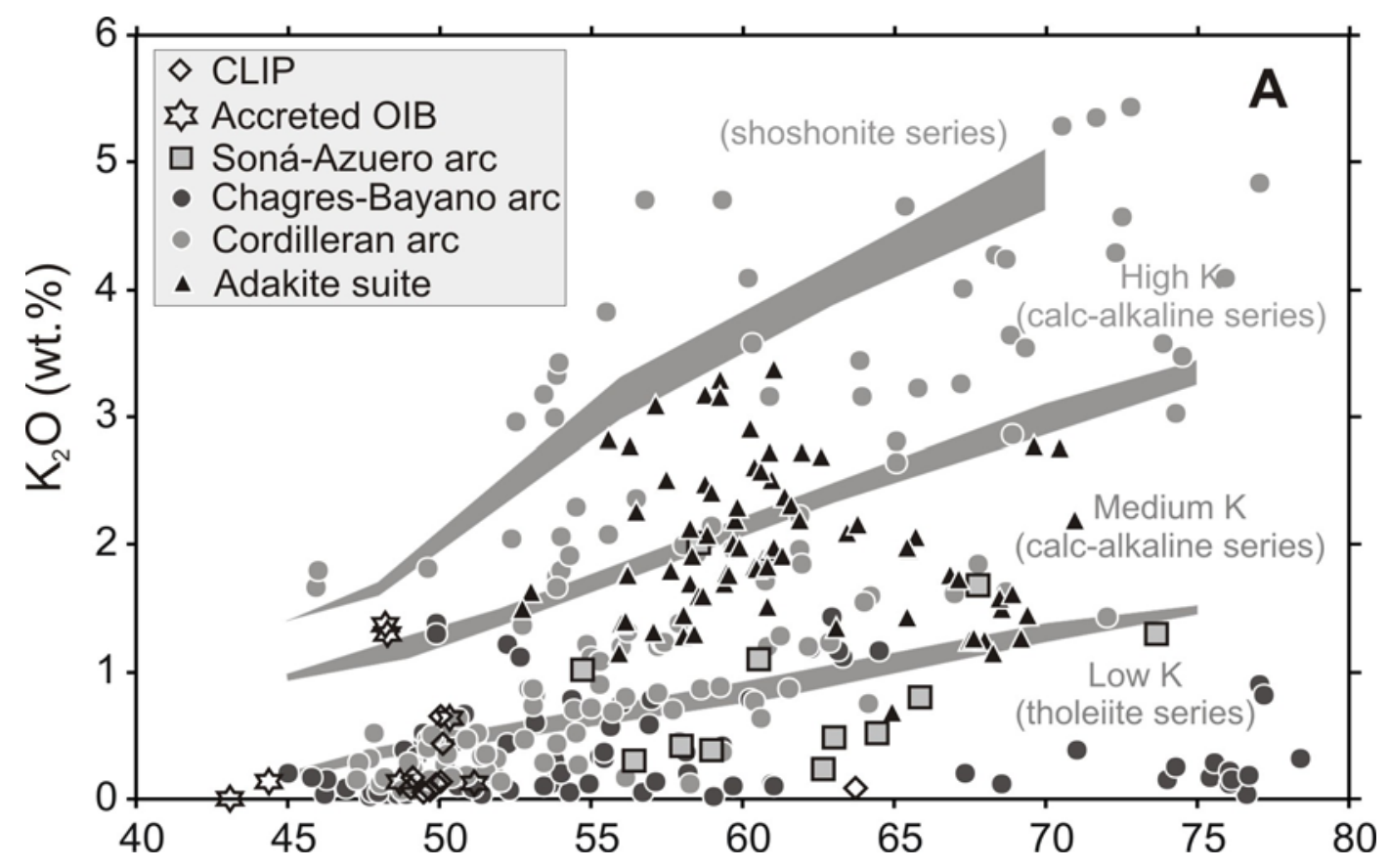




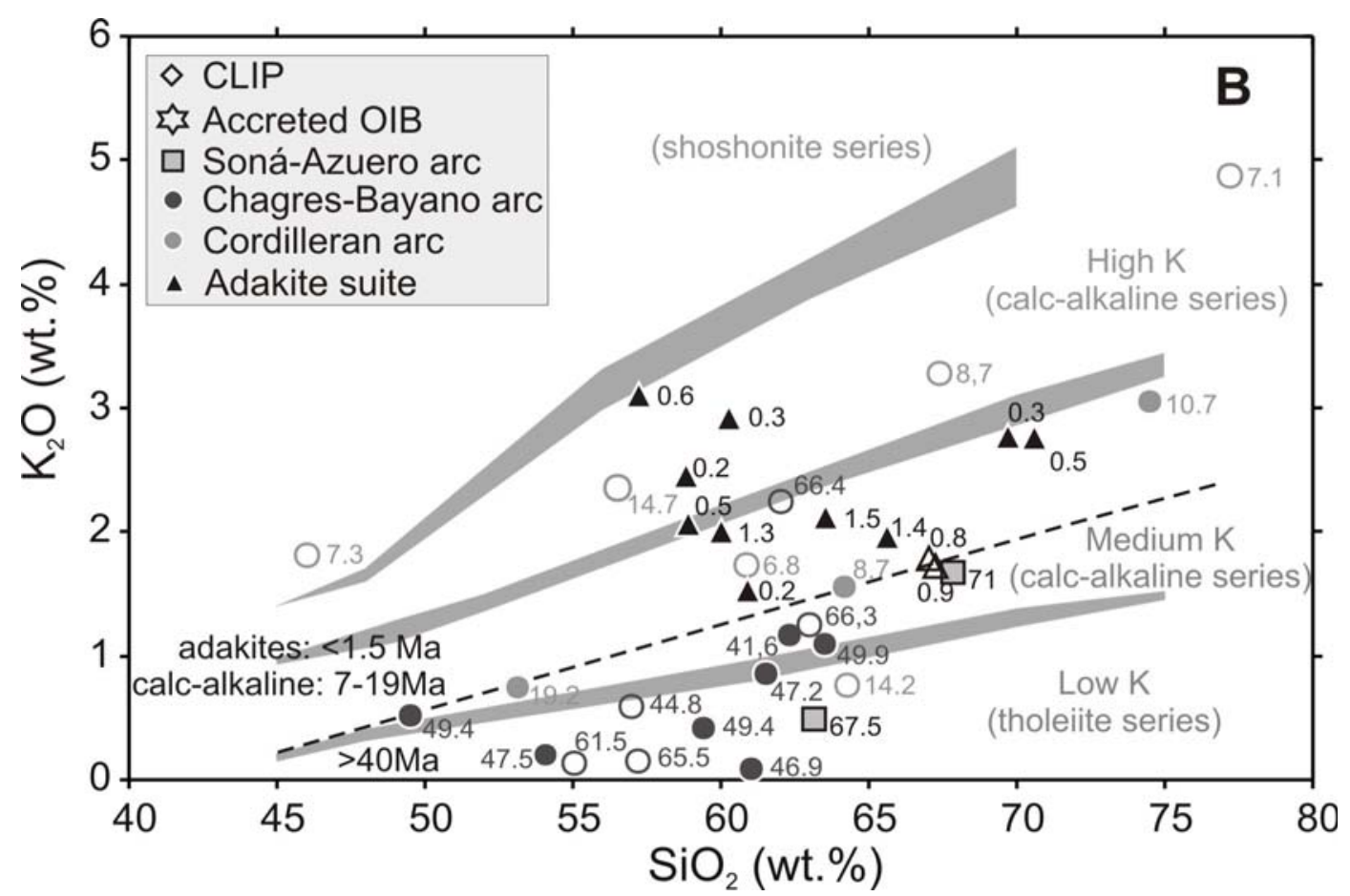

Figure 5.4. (this and previous page) Subdivision of subalkaline rocks after Rickwood (1989) based on the basis of $K_{2} O$ versus silica content: $(A)$ all samples and (B) only dated samples. Open data symbols denote altered samples (see text for discussion). The numbers by the data points in $(B)$ are the ${ }^{40} \mathrm{Ar} /{ }^{39} \mathrm{Ar}$ ages. CLIP-Caribbean large igneous province; OIB-ocean island basalt.

Most volcanic and plutonic rocks of westerncentral Panama are subalkaline in character (Figs. 5.3 and 5.4). Although care was taken to analyze only fresh samples, thin section examination has revealed minor degrees of secondary alteration in some samples. Therefore, some alkali values in the data table (full data table in the appendix) and Figures 5.3 and 5.4 may not be absolutely reliable due to the fact that these elements are easily affected by secondary alteration.

\subsubsection{Major Element Geochemistry}

The Caribbean large igneous province suite in Panama consists mainly of submarine flood basalts (43-51 wt\% $\left.\mathrm{SiO}_{2}\right)$ that are characteristic of the oceanic basement of the Caribbean plate generated between 139 to 69 Ma. Most Caribbean large igneous province basement samples are classified in Figure 5.4 as tholeiites following Rickwood (1989). The remaining five types are subdivided into two more subgroups on the basis of trace element patterns (Fig. 5.6). Accreted OIB denotes accreted ridges and ocean islands that have an enriched, intraplate geochemical signature (Alvarado et al., 1992; Hoernle et al., 2002). Also, there are some rare samples with 
an arc signature that have been found within the Caribbean large igneous province terranes in central and western Panama (Soná-Azuero arc), which are similar in composition to the Chagres-Bayano arc rocks.

The Chagres-Bayano arc is represented mostly by samples from the Upper Rio Chagres region located northeast of the Panama Canal (Wörner et al., 2005, 2009; Fig. 5.2). The Chagres Igneous Complex is an exposed section through a highly tectonized Late Cretaceous to mid-Tertiary submarine lava flow-dike complex, associated subvolcanic intrusive rocks (gabbros to granites), and overlying and intercalated volcanic breccias. This magmatic sequence formed between 66 and 42 $\mathrm{Ma}$ (see discussion of age data below) and was previously grouped into the Caribbean large igneous province domain by previous workers (e.g. Hoernle et al., 2002 and others). However, as will be shown below based on trace element systematic, all rocks of the Chagres-Bayano region have a clear arc geochemical affinity.

We define a Cordilleran arc mostly based on the regional occurrence of deeply eroded volcanic edifices and their intrusive counterparts along the western Panamenian Cordillera that were originally described by deBoer et al. (1988) and Defant et al $(1991 a, 1991 b)$. Ages for rocks from the Cordilleran arc fall into the Oligocene to Miocene, which correspond to magmatic activity in southern Costa Rica around that time (Drummond et al., 1995). This group is mostly comprised by lavas, dikes and intrusives that are variably altered. However, fine-grained aphyric andesites also occur, which are particularly fresh and have been preferentially sampled.

The last sample group (Adakite suite) comprises a suite of andesitic to dacitic rocks (Fig. 5.3) from geographically scattered locations in central-western Panama that are associated with isolated stratovolcanoes in the Veraguas and Chiriquí provinces and occur as remnants of dacitic ignimbrites that span the Panama-Costa Rica border (Defant and Drummond, 1990; Defant et al., 1991a, 1991b; Johnston and Torkelson, 1997; Abratis and Wörner, 2001). These rocks have 58-71 wt. \% $\mathrm{SiO}_{2}$, steep heavy REE patterns, and high $(\mathrm{Sm} / \mathrm{Yb})_{\mathrm{n}}$ ratios of 2.47-10.3 and are generally younger than $5 \mathrm{Ma}$ (Fig.5.5). As illustrated in Figures 5.3, the three arc suites (Soná-Azuero arc, Chagres-Bayano arc and Cordilleran arc) span the entire compositional range from basalt to rhyolite and from gabbro to granite (45 wt\% to $78.5 \mathrm{wt} \% \mathrm{SiO}_{2}$ ). Samples from the Caribbean large igneous province and accreted OIB groups are mostly of 
basaltic composition and most samples from the two older arc groups, Soná-Azuero arc and Chagres-Bayano arc, fall into the low-K array (Fig. 5.4A).
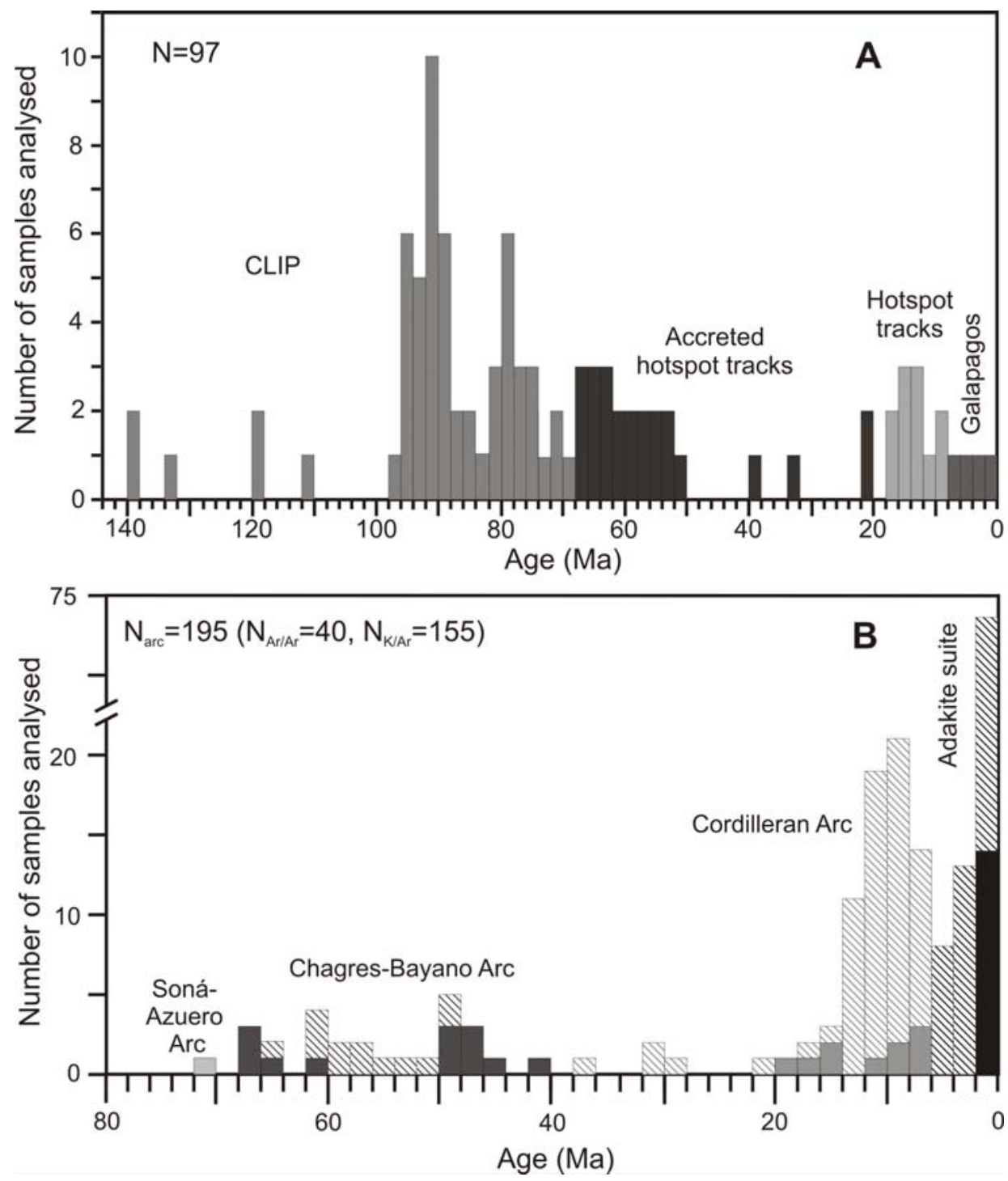

Figure 5.5. (A) Age distribution of CLIP rocks and Galápagos-derived seamounts (after Hoernle et al. 2004). Data sources: Alvarado et al. (1997); Christie et al. (1992); Hauff et al. (2000a); Hoernle et al. (2002, 2004); Kerr at al. (1997, 2002); Lapierre et al. (1999); Revillon et al. (2000a); Sinton et al. (1996, 1997, 1998); White et al. (1993). (B) Age distribution of arc rocks in central and western Panama and in southern Costa Rica; Grey bars- ${ }^{40} \mathrm{Ar} /{ }^{39} \mathrm{Ar}$ data from Abratis and Wörner (2001); black bars-this study; hatched bars-KJAr data from Keseler et al. (1977), de Boer et al. (1991), Defant et al. (1991 a, 1991b, 1992), Drummond et al. (1995), and Maury et al. (1995). CLIP-Caribbean large igneous province.

A few analyses plot in the medium- $\mathrm{K}$ and high- $\mathrm{K}$ field, most likely as a consequence of secondary alteration and thus these samplesare not considered further. Considering only the dated, pristine samples, the Soná-Azuero arc and ChagresBayano arc plot only in the low-K and lower part of the medium-K array. The 
Cordilleran arc samples are extremely variable in $\mathrm{K}_{2} \mathrm{O}$ content, spanning the range from low-K to shoshonitic compositions. Some of this scatter is likely due to alteration.

Considering only the dated and pristine samples, the rocks of the Cordilleran arc plot exclusively in the medium-K array (Fig. 5.4). Samples of the Adakite suite also show some scatter with respect to $\mathrm{K}_{2} \mathrm{O}$ (Fig. 5.4A), but all adakite samples are fresh and unaltered and the majority fall in the medium-K and high-K field (Fig. 5.4). It is not possible from our age data to precisely determine the timing for the change from tholeiitic to calc-alkaline magmatism (Figs. 5.3 and 5.4). Rocks of the Soná-Azuero arc and Chagres-Bayano arc are mainly tholeitic but both groups contain some calcalkaline samples. The Cordilleran arc is composed of both tholeiitic and calc-alkaline samples. No compositional evolution through time is seen within single rock suites. Therefore, it is likely that the change from largely tholeiitic to predominantly calcalkaline magmatism took place at different times in different locations across Panama during Cordilleran arc magmatism. This is consistent with the general age pattern for volcanism in southern Costa Rica (MacMillan et al., 2004; and discussion below).

\subsection{2 ${ }^{40} \mathrm{Ar} /{ }^{39} \mathrm{Ar}$ Dating}

High-precision ${ }^{40} \mathrm{Ar} /{ }^{39} \mathrm{Ar}$ ages were determined for a subset of 35 samples. Plateau ages, determined by incremental heating are listed in Table 5.1 and displayed in histogram form in Figure 5.5 (see also complete Ar-results in the appendix). These samples span the entire range with respect to composition and geographic location across west-central Panama. Although $\mathrm{K}_{2} \mathrm{O}$ values are relatively low in the whole rocks, precise dating of mineral separates of amphibole and K-feldspar was possible. There now is sufficient geochronologic data to examine the temporal nature of magmatism across southern Central America over the past 100 million years. The small overlap in age between Caribbean large igneous province (>69 Ma) and arc rocks ( $<71 \mathrm{Ma}$ ) is shown in Figure 5.5; in fact, only two samples fall into the overlap interval between 69 and $71 \mathrm{Ma}$. Our oldest ages of 71- 67.5 Ma for Soná-Azuero arc samples come from the Azuero and Soná Peninsulas (Fig. 5.2). Thus, the age data strongly imply that subduction-related magmatism in Panama commenced $\sim 71$ million years ago in the vicinity of the CLIP complexes on the Azuero and Soná peninsulas, subsequently shifting into the Chagres region (Fig. 5.2) of the central Cordillera de Panama at $66 \mathrm{Ma}$ (Fig. 5.5B). 
Table 5.1. Summary of ${ }^{40} \mathrm{Ar} /{ }^{39} \mathrm{Ar}$ incremental-Heatig experiments (for details see complete Ar-results in the appendix)

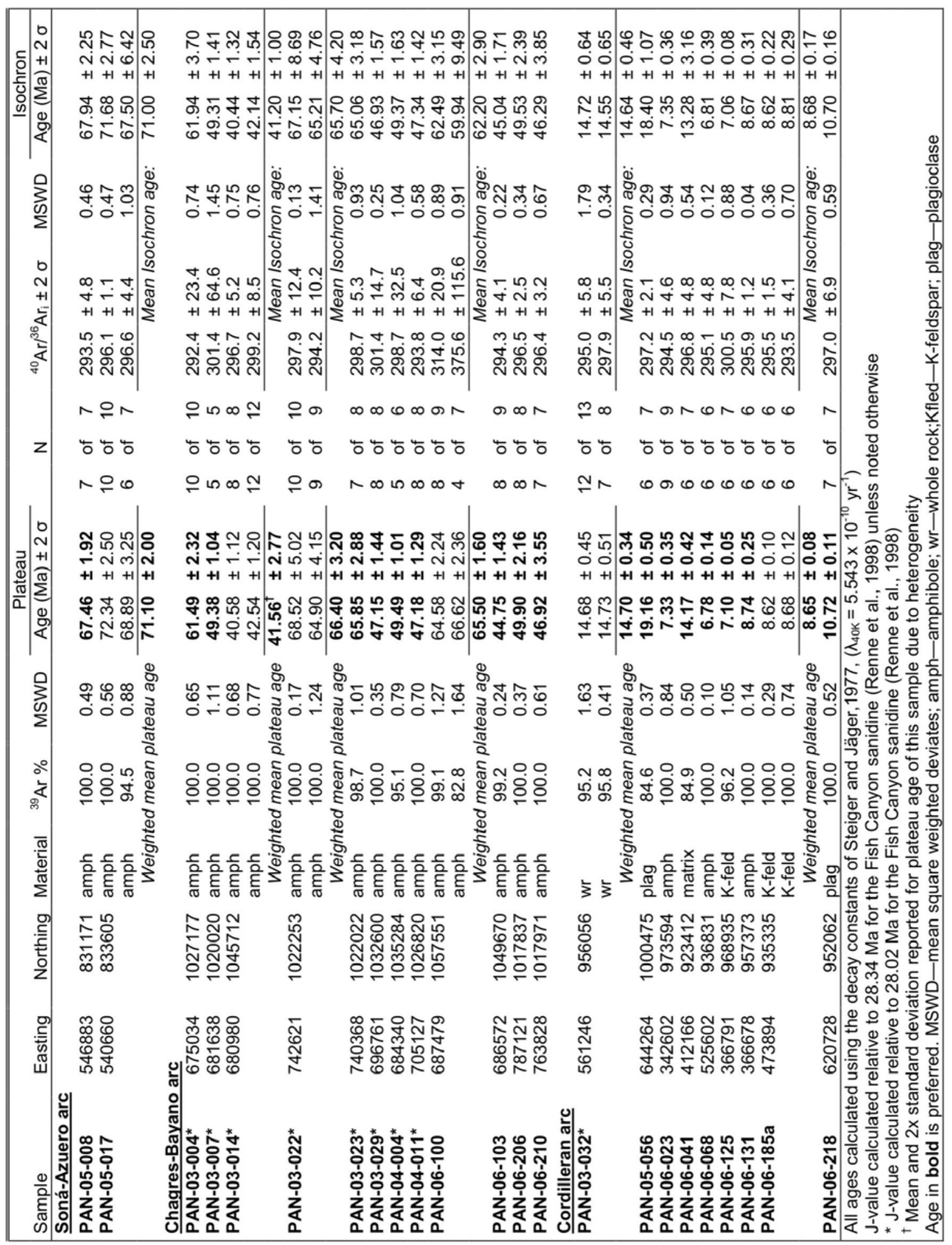


Table 5.1. Summary of ${ }^{40} \mathrm{Ar} /{ }^{39} \mathrm{Ar}$ incremental-Heatig experiments (continued)

\begin{tabular}{|c|c|c|c|c|c|c|c|c|c|c|c|c|c|}
\hline \multirow{2}{*}{$\begin{array}{l}\text { Sample } \\
\text { Adakite suite }\end{array}$} & \multirow[t]{2}{*}{ Easting } & \multirow[t]{2}{*}{ Northing } & \multirow[t]{2}{*}{ Mineral } & \multirow[t]{2}{*}{$\begin{array}{l}{ }^{39} \mathrm{Ar} \\
\%\end{array}$} & \multirow[t]{2}{*}{ MSWD } & \multirow{2}{*}{\multicolumn{2}{|c|}{$\begin{array}{l}\text { Plateau } \\
\text { Age (Ma) } \\
\quad \pm 2 \sigma\end{array}$}} & \multirow{2}{*}{\multicolumn{2}{|c|}{$\mathrm{N}$}} & \multirow[t]{2}{*}{$\begin{array}{l}{ }^{40} \mathrm{Ar}^{36} \mathrm{Ar}_{\mathrm{i}} \\
\pm 2 \sigma\end{array}$} & \multirow[t]{2}{*}{ MSWD } & \multicolumn{2}{|c|}{$\begin{array}{l}\text { Icochron } \\
\text { Age (Ma) } \\
\pm 2 \sigma\end{array}$} \\
\hline & & & & & & & & & & & & & \\
\hline PAN-05-047 & 515419 & 932671 & amph & 100.0 & 0.99 & 0.26 & \pm 0.04 & 7 & of 7 & $297.9 \pm 6.6$ & 1.08 & 0.23 & \pm 0.08 \\
\hline PAN-05-049 & 515419 & 932671 & amph & 100.0 & 0.76 & 0.46 & \pm 0.07 & 6 & of 6 & $302.3 \pm 12.7$ & 0.65 & 0.34 & \pm 0.21 \\
\hline PAN-06-006 & 308969 & 976393 & amph & 92.5 & 0.33 & 1.32 & \pm 0.18 & 5 & of 6 & $294.7 \pm 5.0$ & 0.39 & 1.45 & \pm 0.78 \\
\hline PAN-06-010 & 311164 & 976475 & amph & 100.0 & 1.06 & 1.49 & \pm 0.10 & 6 & of 6 & $290.7 \pm 13.5$ & 0.21 & 1.53 & \pm 0.16 \\
\hline PAN-06-014 & 312003 & 975064 & amph & 100.0 & 0.23 & 0.63 & \pm 0.06 & 6 & of 6 & $296.1 \pm 5.0$ & 0.28 & 0.62 & \pm 0.09 \\
\hline PAN-06-043 & 415967 & 935660 & amph & 100.0 & 0.71 & 0.82 & \pm 0.13 & 5 & of 5 & $297.8 \pm 11.1$ & 0.95 & 0.78 & \pm 0.25 \\
\hline PAN-06-044 & 415724 & 938624 & amph & 100.0 & 0.28 & 0.92 & \pm 0.16 & 5 & of 5 & $299.0 \pm 6.8$ & 0.03 & 0.82 & \pm 0.26 \\
\hline PAN-06-073 & 535861 & 925254 & amph & 100.0 & 0.96 & 1.37 & \pm 0.09 & 6 & of 6 & $296.8 \pm 10.5$ & 1.10 & 1.34 & \pm 0.24 \\
\hline PAN-06-136 & 324735 & 940222 & amph & 99.7 & 0.49 & 0.32 & \pm 0.06 & 5 & of 6 & $296.7 \pm 4.2$ & 0.55 & 0.28 & \pm 0.13 \\
\hline PAN-06-166 & 340254 & 973213 & amph & 99.4 & 0.25 & 0.18 & \pm 0.08 & 6 & of 7 & $295.5 \pm 2.9$ & 0.31 & 0.18 & \pm 0.12 \\
\hline PAN-06-168 & 337490 & 974820 & amph & 92.8 & 0.73 & 0.19 & \pm 0.09 & 4 & of 6 & $299.2 \pm 16.5$ & 0.99 & 0.13 & \pm 0.15 \\
\hline PAN-06-176 & 326350 & 955330 & amph & 100.0 & 0.48 & 0.48 & \pm 0.08 & 6 & of 6 & $295.5 \pm 5.9$ & 0.60 & 0.48 & \pm 0.15 \\
\hline \multicolumn{14}{|c|}{ All ages calculated using the decay constants of Steiger and Jäger,1977, $\left(\lambda_{40 \mathrm{~K}}=5.543 \times 10^{-10} \mathrm{yr}^{-1}\right)$} \\
\hline \multicolumn{14}{|c|}{ J-value calculated relative to $28.34 \mathrm{Ma}$ for the Fish Canyon sanidine (Renne et al., 1998) unless noted otherwise } \\
\hline \multicolumn{14}{|c|}{ * J-value calculated relative to 28.02 Ma for the Fish Canyon sanidine (Renne et al., 1998) } \\
\hline \multicolumn{14}{|c|}{${ }^{\dagger}$ Mean and $2 x$ standard deviation reported for plateau age of this sample due to heterogeneity } \\
\hline \multicolumn{14}{|c|}{$\begin{array}{l}\text { Age in bold is preferred. MSWD-mean square weighted deviates; amph-amphibole; wr-whole rock;Kfled-K-feldspar; } \\
\text { plag-plagioclase }\end{array}$} \\
\hline
\end{tabular}

This conclusion is consistent with published K-Ar data (Kesler et al., 1977), stratigraphic evidence of Fisher and Pessagno (1965) and Weyl (1980), and a recent study by Buchs et al. (2007) who concluded that arc magmatism in Costa Rica and Panama was initiated in Late Cretaceous to early Tertiary time. However, Pindell et al. (2006) cite evidence from clasts in boreholes and detrital minerals in older sediments to suggest a possible onset of arc magmatism during Albian time $\sim 95 \mathrm{Ma}$. However, because the latter evidence is scarce and not based on measured trace element character of these rocks, and because of the consistent and abundant age data discussed above, we conclude that a later onset of subduction in the western margin of the Caribbean plate at around $71 \mathrm{Ma}$ is much more likely.

The oldest Chagres-Bayano arc rocks of the Cordillera de Panama (66 Ma) are found in the Chagres and Lake Bayano areas east of the Panama Canal (Fig. 5.2), but younger rocks of this group in the same region range in age down to $41.6 \mathrm{Ma}$ (Table 5.1). Given the abundance of ages determined and the complete coverage of lithologies and their spatial distribution, the paucity of ages between 61.5 and $50 \mathrm{Ma}$ in Figure 5.4 is interpreted to be geologically meaningful. Earlier (66.4-61.5 Ma) and later (49.4- 41.6 Ma) magmatic suites within the Chagres-Bayano arc suite, however, are indistinguishable geochemically. Based on the wide regional distribution and the 
dozens of Chagres-Bayano arc samples dated, this temporal gap is unlikely to be due to insufficient sampling. A temporal gap during the Chagres-Bayano arc magmatic episode is also supported by the work of Kesler et al. (1977), who determined K-Ar ages for amphibole and feldspar from 65 to $53 \mathrm{Ma}$ on the Azuero peninsula (Fig. 5.2) and 62- $51 \mathrm{Ma}$ at Cerro Azul on the eastern boundary of the Chagres region. The K-Ar ages of Maury et al. (1995) extend the volcanic arc toward the east into the Darien region of Panama from 61 to $55 \mathrm{Ma}$ (the Rio Morti area east of Lake Bayano in Fig. 5.2). These data fall within the age range observed for the Chagres region and Kesler et al. (1977) reported K-Ar ages for feldspar and amphibole of 49-48 Ma for an in-situ quartz diorite from the Rio Pito mineralized area farther east.

All of these observations above are in good agreement with the work of Recchi (1975) who postulated an E-W-trending volcanic arc between the Soná peninsula in Panama and northwestern Colombia during Late Cretaceous time (Fig. 5.1), which subsequently was offset by a sinistral motion along a northwest-trending fault zone that is located in the vicinity of the present-day Canal Zone. However, based on our high precision ${ }^{40} \mathrm{Ar} /{ }^{39} \mathrm{Ar}$ age data, we hold that magmatism of the Chagres-Bayano arc system was discontinuous in time and that the majority of arc magmatic products were generated in two main periods from 68 to $60 \mathrm{Ma}$ and from 50 to $40 \mathrm{Ma}$.

Rocks of the Cordilleran arc suite underlying the El Valle and La Yeguada volcanic areas, scattered regions of the Cordillera de Panama, and domes from the forearc region (Fig. 5.2) range mostly in K-Ar-ages from 22 to 7 Ma (de Boer et al., 1988, 1991; Defant et al., 1992; Drummond et al., 1995) with few exceptions (Fig. 5.5; Kesler et al., 1977 and de Boer et al. 1995). Our new ages from the main Cordillera de Panama and the forearc regions (19.2 and 6.8 Ma) also fall within this range (Table 5.1), consistent with the majority of the K-Ar ages. We therefore argue that the main phase of magmatic activity of the Cordilleran arc occurred between 22 and 7 Ma. This phase was followed by a volcanic lull of 2 to 5 million years (Fig. 5.5B) after which only adakites were erupted in southern Costa Rica and western Panama. It is interesting to note that an older volcanic gap between 11 and $6 \mathrm{Ma}$ was also observed in southern Costa Rica by MacMillan et al. (2004). These authors, however, noted intrusive activity during this time based on dating plutonic rocks that became exposed during strong uplift after the collision of the Cocos Ridge. Such 
significant uplift did not occur in western Panama and thus intrusive rocks younger than 7 Ma may have remained concealed.

The heavy rare earth element (HREE)-depleted andesites and dacites of the Adakite suite were erupted only at isolated, geographically-scattered volcanic centers in southern Costa Rica and westcentral Panama over the past 3.5 million years (de Boer et al., 1995; Johnston and Thorkelson, 1997; Abratis and Wörner, 2001; and new data from this study; Table 5.1). These adakitic rocks are associated with stratovolcanoes at El Valle, La Yeguada, and Barú, and occur as remnants of dacitic ignimbrites that span the Panama-Costa Rica border (Defant and Drummond, 1990; Defant et al., 1991a, 1991b, 1992).

\subsubsection{Trace Element Geochemistry}

The trace element compositions of the rocks analyzed in this study are compiled in the full data table (appendix). Mantle-normalized trace element patterns are shown in Figure 5.6, which displays clear differences in trace element patterns for the different age groups with respect to levels of incompatible element enrichment and concentrations of HFSE.

Caribbean large igneous province trace element patterns in Figure 5.6 are almost horizontal, with only a few, unsystematic variations observed for the fluid-mobile elements such as $\mathrm{Ba}, \mathrm{K}, \mathrm{Pb}$, and $\mathrm{Sr}$. These variations are probably a consequence of secondary, low-temperature hydrothermal alteration.

Accreted OIB shows a clear enrichment in the more incompatible elements and low rare earth element patterns to the right of Sm (HREE) concentrations relative to Caribbean large igneous province and primitive mantle (Fig. 5.6). This pattern indicates an intraplate mantle source, an interpretation that is consistent with the ideas of Alvarado et al. (1992) and Hoernle et al. (2002) who described a set of 70$20 \mathrm{Ma}$ accreted terranes from Costa Rica that have this same trace element signature. These were interpreted as seamounts from the Galápagos hotspot track that were accreted to the Central American Arc (Fig. 5.1). The Soná-Azuero arc samples show a clear subduction-related volcanic arc trace element signature that is characterised by depletion in $\mathrm{Nb}$ and $\mathrm{Ta}$ and enrichment of fluid-mobile elements such as $\mathrm{Ba}, \mathrm{K}, \mathrm{Pb}$, and $\mathrm{Sr}$. These are rare rocks within the Soná and Azuero peninsulas (Figs. 5.1 and 5.2) and provide important insights into the earliest evolution of the volcanic arc in this region (Buchs et al., 2007). Unfortunately, we 
have no information about structural relations relative to the other Caribbean large igneous province rocks due to their very limited exposure. The new ${ }^{40} \mathrm{Ar} /{ }^{39} \mathrm{Ar}$ ages for Soná-Azuero arc rocks range from 68 to $71 \mathrm{Ma}$ and, thus, are slightly older than those observed for the Chagres-Bayano arc rocks of the Chagres region (see below).

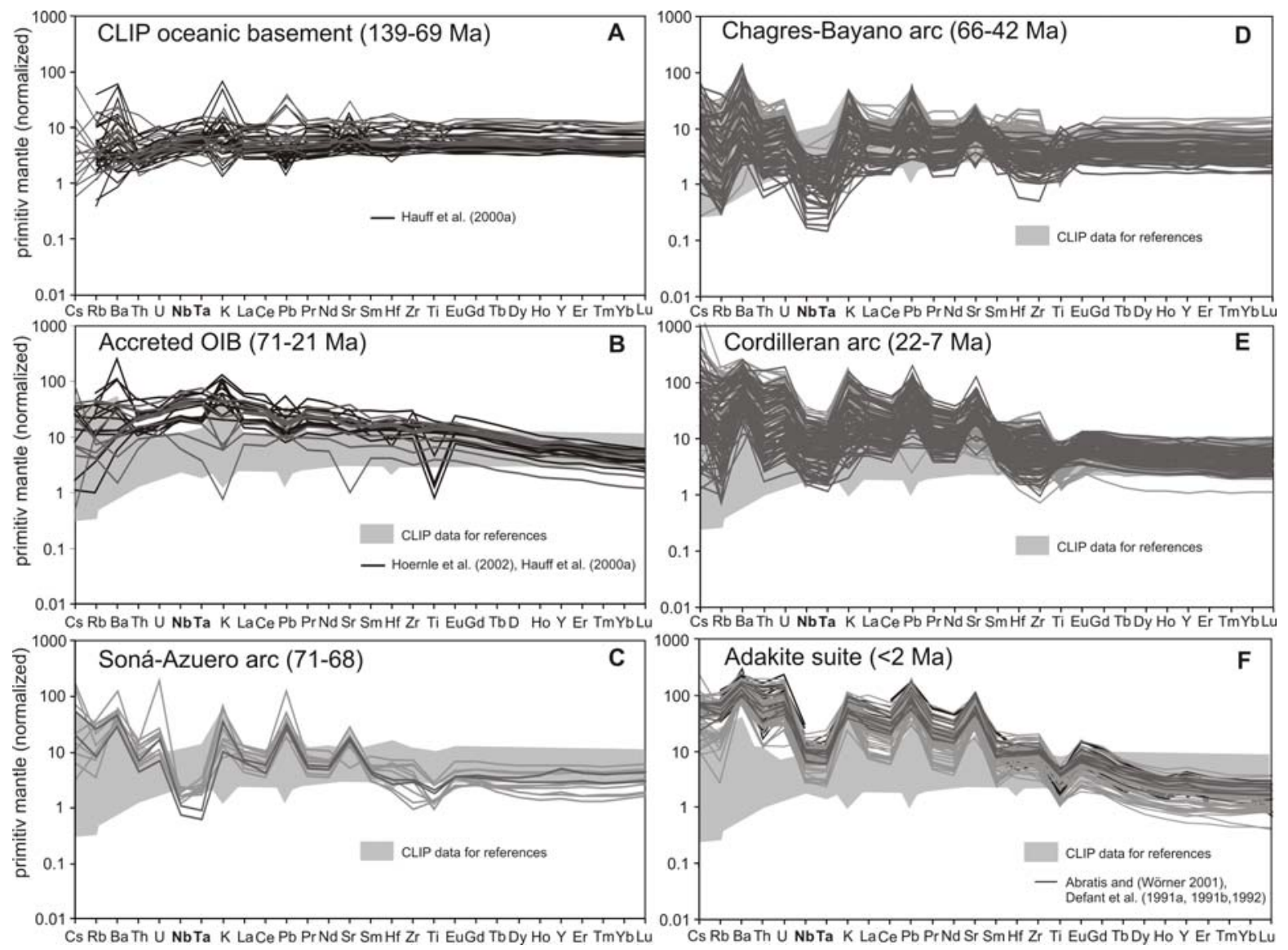

Figure 5.6. Trace element patterns, normalized to primitive mantle (Sun and McDonough 1989), for igneous rocks from central and western Panama. Elements are plotted according to their decreasing incompatibility from left to right. Dark colours denote samples with $\mathrm{SiO}_{2}<57$ wt\%, whereas pale grey indicate samples with $\mathrm{SiO}_{2}$ $>57 w t \%$. The light-grey field shows the CLIP data for reference. Literature data from the sources cited in the text are shown in black lines for comparison. CLIP-Caribbean large igneous province; OIB- ocean island basalt.

Most rocks of the Chagres-Bayano arc were sampled in the Chagres region northeast of the Panama Canal (Fig. 5.2) and in the Bayano area to the east. The large geochronological data set shown in Figure 5.5 and, in particular, the new ${ }^{40} \mathrm{Ar} /{ }^{39} \mathrm{Ar}$ ages for the Chagres region show that voluminous subduction magmatism in this region started somewhat earlier at $66 \mathrm{Ma}$, slightly later than in the Soná and Azuero areas where arc magmatism is first recorded at $71 \mathrm{Ma}$, and lasted until 42 Ma. Most Chagres-Bayano arc samples are characterized by horizontal trace 
element patterns to the right of Sm similar to Caribbean large igneous province samples, although a few rocks are relatively enriched whereas others are relatively depleted by comparison. The most obvious geochemical feature of this group is the large variation in $\mathrm{Nb}$ and $\mathrm{Ta}$ and for some samples a very strong depletion in these elements. Some of the samples are even below primitive mantle values in $\mathrm{Nb}$ and Ta.

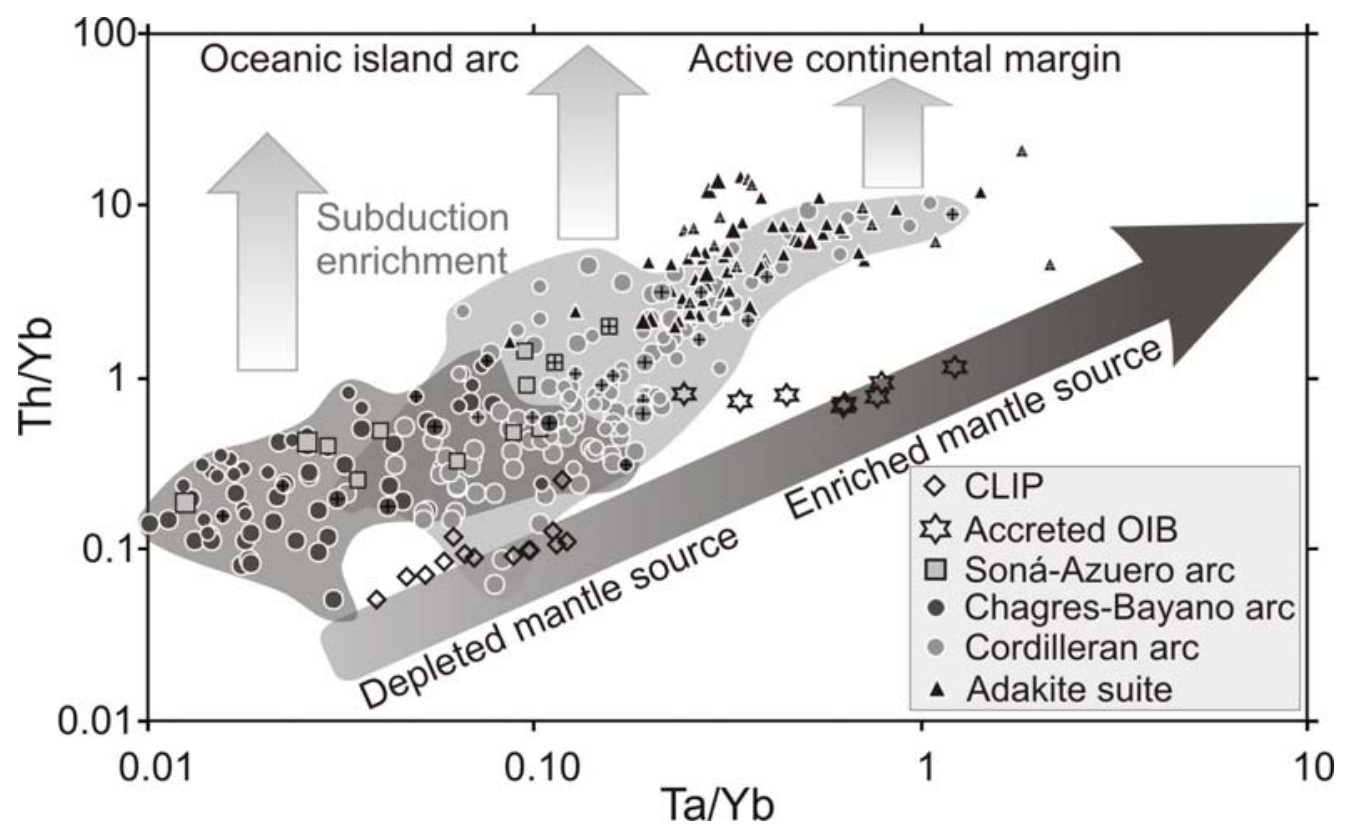

Figure 5.7. Plot of Ta/Yb versus $\mathrm{Th} / \mathrm{Yb}$ for magmatic rocks from central and western Panama. This diagram can be used to recognize arc magmas generated via subduction and fluid enrichment of a depleted to enriched mantle sources. Large symbols denote samples with $<57$ wt\% $\mathrm{SiO}_{2}$, whereas small symbols indicate samples with $>57$ wt\% $\mathrm{SiO}_{2} .{ }^{40} \mathrm{Ar}{ }^{39} \mathrm{Ar}$ dated samples are denoted with crosses. CLIP-Caribbean large igneous province; OIB-ocean island basalt.

Because $\mathrm{Nb}$ and $\mathrm{Ta}$ are not affected by fluid addition, this implies that the mantle source region at this time was heterogeneous and subject to large variations in incompatible element composition prior to fluid enrichment. An alternative view would attribute this feature to involvement of variable amounts of subducted sediments, or fluids derived therefrom, in their source (see discussion below). We have insufficient data to test whether there are systematic compositional changes with time in this group or if there might be a compositional trend from tholeiitic to calc-alkaline rocks as the arc matured. However, there is a clear compositional difference between the Soná-Azuero arc and Chagres-Bayano arc rocks (71-42 Ma) and Caribbean large 
igneous province basement rocks that were erupted before $69 \mathrm{Ma}$ (Hoernle et al., 2004).

Compared to the Chagres-Bayano arc, samples of the Cordilleran arc exhibit a slightly narrower range in $\mathrm{Nb}$ and Ta concentrations. Only very few samples from this phase of magmatism have depleted trace element patterns, which is typical of many of the arc magmas erupted earlier in the development of the Panama volcanic arc system (Figs. 5.6- 5.8). Based on trace element ratios and patterns (Figs. 5.6- 5.8), we conclude that the change from a depleted tholeiitic magma source indicative of the early stage of arc magmatism to a more mature, less depleted magma source must have taken place at the beginning of the Cordilleran arc magmatic episode at 22 Ma. This change also involved a transition to a more homogeneous magma source with time.

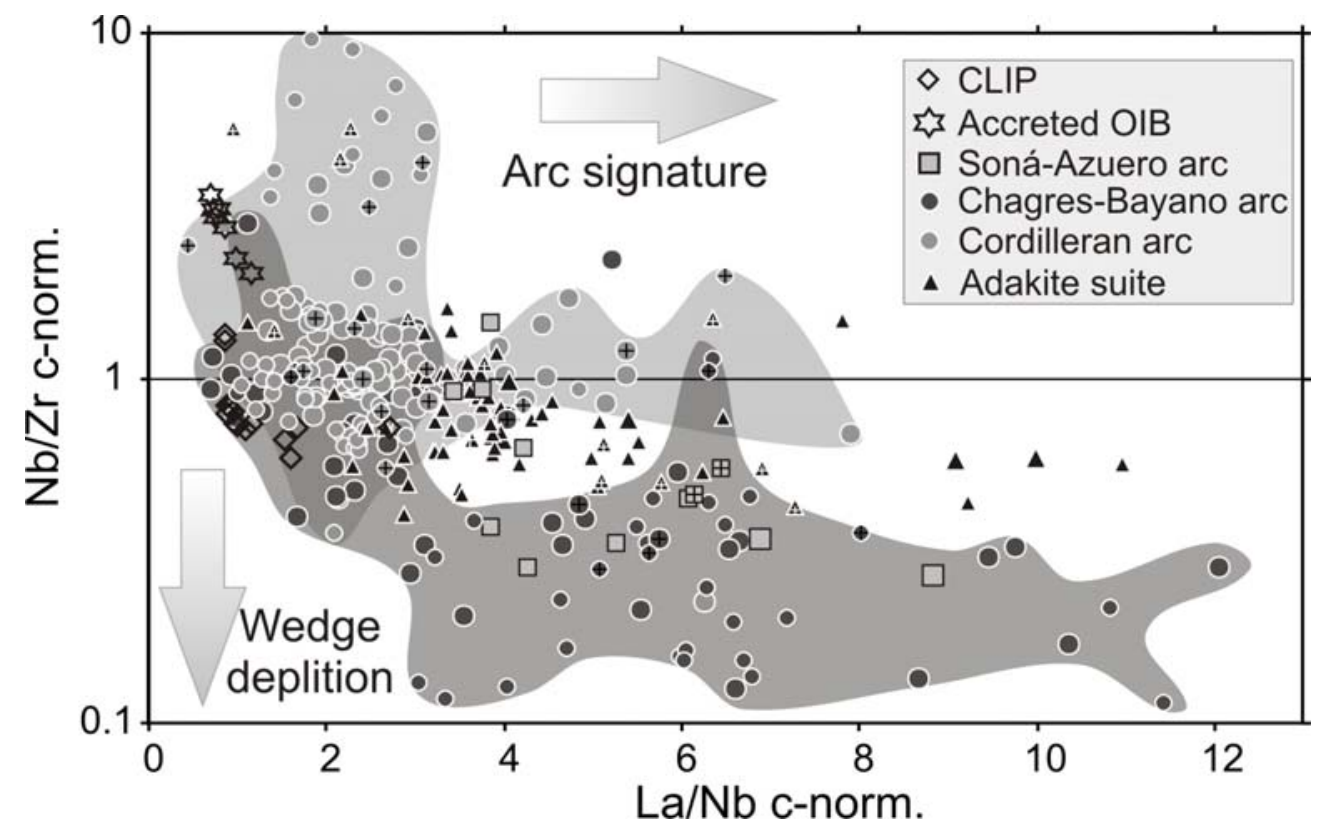

Figure 5.8. Plot of chondrite normalized ratios of $\mathrm{La} / \mathrm{Nb}$ versus $\mathrm{Nb} / \mathrm{Zr}$ showing the different affects of wedge depletion and arc signature for the different arc groups. Large symbols denote samples with $<57$ wt\% $\mathrm{SiO}_{2} .{ }^{40} \mathrm{Ar} /{ }^{39} \mathrm{Ar}$ dated samples denoted with crosses.

The Adakite suite forms form a separate group that is characterized by steep REE patterns from $\mathrm{Sm}$ to $\mathrm{Yb}$ (Fig. 5.6), which is diagnostic of residual garnet in the magma source. Our samples of this group are all younger than $2 \mathrm{Ma}$, indicating a gap in magmatism of a few million years between the cessation of the Cordilleran arc stage of magmatism and the onset of the Adakite suite phase. There are two models for genesis of the Panama-Costa Rican adakites. Johnston and Thorkelson (1997) 
argue that a slab window formed due to subduction of the Panama spreading center and that Cocos plate mid-ocean ridge basalt (MORB) then melted to form adakitic magmas. By contrast, Abratis and Wörner (2001) consider that Cocos MORB is not a viable source for the adakites and instead, based on $\mathrm{Pb}$ isotope evidence, favor melting of the leading edge of the Cocos ridge (Fig. 5.1) after its collision with the Chortis block and consequent slab window formation. In any case, the magma source for the Adakite suite stage of Panamanian magmatism is significantly different from that which produced the magmas during the earlier Soná-Azuero arc, ChagresBayano arc, and Cordilleran arc stages.

The plot of $\mathrm{Ta} / \mathrm{Yb}$ versus $\mathrm{Th} / \mathrm{Yb}$ in Figure 5.7 illustrates the effect of slab enrichment on depleted mantle source regions with low ratios of $\mathrm{Th} / \mathrm{Yb}$ and $\mathrm{Ta} / \mathrm{Yb}$ (i.e., MORBsource mantle) to mantle sources enriched in both Th and Ta (e.g., OIB-source mantle). Magmas produced by subduction-related arc magmatism in which enrichment of a depleted mantle source occurs by the introduction of LILE-enriched fluids and sediments, are differentiated in Figure 5.7 by their enrichment in Th but not $\mathrm{Ta}$, i.e., higher $\mathrm{Th} / \mathrm{Yb}$ ratio at constant $\mathrm{Ta} / \mathrm{Yb}$ ratio.

The Caribbean large igneous province basement rocks fall largely within the depleted mantle field in Figure 5.7. By contrast, accreted OIB samples have higher $\mathrm{Th} / \mathrm{Yb}$ and $\mathrm{Ta} / \mathrm{Yb}$ ratios that are indicative of derivation from an enriched mantle source whereas the Soná-Azuero arc samples have higher $\mathrm{Th} / \mathrm{Yb}$ ratios that are suggestive of fluid enrichment of a depleted mantle source. Overall, the Chagres-Bayano arc, Cordilleran arc, and Adakite suite samples in Figure 5.7 define a trend that is parallel to the mantle trend with higher $\mathrm{Th} / \mathrm{Yb}$ ratios. Samples of the Soná-Azuero arc group form a field contained within the low $\mathrm{Ta} / \mathrm{Yb}$ portion of the broad field defined by the Chagres-Bayano arc rocks. This situation is not unexpected, as both groups are considered to have been derived from a depleted mantle wedge source (see above). As demonstrated by their trace element patterns (Fig. 5.6), the Chagres-Bayano arc reflects a fluidmodified but variable depleted mantle source, as documented by the more than one orders of magnitude range observed in both $\mathrm{Th} / \mathrm{Yb}$ and $\mathrm{Ta} / \mathrm{Yb}$ ratios. By comparison, the majority of rocks of the Cordilleran arc require a more enriched magma source composition that overlaps the high-Ta/Yb end of the Chagres-Bayano arc field and extends into high values of the Adakite suite field., The Cordilleran arc is in the same range as the Chagres-Bayano arc in terms of degree of homogeneity and fluid modification of the mantle source. The Adakite suite exhibits the highest 
$\mathrm{Ta} / \mathrm{Yb}$ and $\mathrm{Th} / \mathrm{Yb}$ ratios, which is interpreted to reflect the strong subduction enrichment of an already enriched mantle source.

The arc signature is strongest for the Adakite suite and Chagres-Bayano arc samples (Fig. 5.8). For the Chagres-Bayano arc this may be mainly due to the depleted source composition, which even for a small amount of arc fluids produces a large effect. The Cordilleran arc samples display less of an arc signature and most are clearly more enriched than Chagres-Bayano arc and Soná-Azuero arc samples. The Soná-Azuero arc is intermediate between the Chagres-Bayano arc and the Cordilleran arc in terms of wedge depletion and arc signature.

The trace element patterns of Figure 5.6 and ratios of Figure 5.7 and 5.8 document a systematic temporal evolution in magma composition beginning in Cretaceous time that continues to the present. We interpret this change in mantle source composition over more than 100 million years to be related to tectonic rearrangements in a developing complex arc setting through time (see below).

\subsubsection{Oxygen Isotope Geochemistry}

The object of the O-isotope portion of the study was to determine the primary magmatic $\delta^{18} \mathrm{O}$ values for a subset of 56 of the Panamanian intrusive and volcanic rocks using theoretical and experimental mineral-mineral and mineral-melt isotopic fractionations and thereby establish the O-isotope character of the source region from which their parental melts originated. The samples analyzed span a wide range in bulk composition from $46 \%$ to $77 \% \mathrm{SiO}_{2}$. As a consequence of their age and complex geological history, the samples were subjected to varying degrees of postcrystallization alteration and several samples display visible alteration in hand specimen or thin section. Because of concern about the geochemical integrity of some samples, it was not appropriate to determine the O-isotope composition of whole rocks. Instead, ${ }^{18} \mathrm{O} /{ }^{16} \mathrm{O}$ ratios were measured for 87 mineral separates that appeared to be entirely free of alteration under a binocular microscope that were obtained by hand-picking from seven intrusive rocks, one magmatic segregation vein, and phenocrysts from 47 volcanic samples. A particular focus was on the mafic minerals amphibole and clinopyroxene but plagioclase, which is more susceptible to the effects of post-crystallation O-isotopic modification, was included where present, and the glass matrix of three volcanic rocks was also sampled. Measured ${ }^{18} \mathrm{O} /{ }^{16} \mathrm{O}$ ratios are reported in Table 5.2 in the familiar " $\delta$ " notation $\left[\delta^{18} \mathrm{O}(\%)=\right.$ 
$\left.\left({ }^{18} \mathrm{O} /{ }^{16} \mathrm{O}_{\text {sample }} /{ }^{18} \mathrm{O} /{ }^{16} \mathrm{O}_{\text {standard }}-1\right) \times 1000\right]$ relative to the VSMOW, together $\delta^{18} \mathrm{O}$ values estimated for equilibrium magmas at high temperature that were calculated following the procedure of Bindeman et al. (2004). From the analysis below, magmatic $\delta^{18} \mathrm{O}$ values were estimated for 41 of the 56 rocks of this study, 15 of which were based on ${ }^{18} \mathrm{O} /{ }^{16} \mathrm{O}$ ratios of multiple minerals.

Table 5.2 presents ${ }^{18} \mathrm{O} /{ }^{16} \mathrm{O}$ ratio measurements for 47 amphibole, 11 clinopyroxene and 29 plagioclase separates. The distribution of these $\delta^{18} \mathrm{O}$ values is shown in histogram form in Figure 5.9 and their ranges for the four groups sampled are presented in Table 5.3. For the Panama suite as a whole, $\delta^{18} \mathrm{O}_{\mathrm{am}}=3.6$ to $6.9 \%$, $\delta^{18} \mathrm{O}_{\mathrm{cpx}}=4.9$ to $6.6 \%$, and $\delta^{18} \mathrm{O}_{\mathrm{fsp}}=3.9$ to $10.9 \%$. The range of O-isotope variation observed for feldspar $(7.0 \%)$ is much larger than that for amphibole $(3.3 \%)$, which in turn is about twice that recorded for clinopyroxene $(1.7 \%)$ which was only separated from the adakite lavas. The sections which follow discuss the extent to which this $\mathrm{O}-$ isotope data can be used estimate magmatic ${ }^{18} \mathrm{O} /{ }^{16} \mathrm{O}$ for the parental magmas of the Panamanian igneous rocks.

From studies of peridotite xenoliths (lonov et al., 1994; Mattey et al., 1994) and a wide variety of volcanic rocks (Eiler et al., 1996, 1997, 2000; Bindeman et al., 2004, 2005), it is known that normal basaltic melts derived from hydrous melting of the subducting mantle wedge in convergent plate margin settings should have ${ }^{18} \mathrm{O} /{ }^{16} \mathrm{O}$ ratios in the range of $\delta^{18} \mathrm{O}=5.8 \pm 0.2 \%$ and, as demonstrated by Matsuhisa (1979), Harmon and Gerbe (1992), and Bindeman et al. (2004), derivative high-Si dacitic to rhyolitic melts produced solely by closed-system crystal fraction should have elevated $\delta^{18} \mathrm{O}$ values that can range up to a maximum of $\sim 7 \%$. Rare instances of young subduction-zone volcanic rocks containing olivine with $\delta^{18} \mathrm{O}$ up to $7.1 \%$, implying melt $\delta^{18} \mathrm{O}$ values of up to $\sim 8 \%$, have been documented for Kamchatka (Dorendorf et al., 2000; Bindeman et al., 2004) and for a variety of adakites from Panama (Abratis 1998; Bindeman et al., 2005) and various other circum-Pacific localities by Bindeman et al. (2005).

Because most rocks and fluids contain similar concentrations of oxygen, the $\mathrm{O}$ isotope composition of an igneous rock can be used both as a screening tool for evaluating effects of secondary alteration and, if high-temperature equilibrium $\mathrm{O}$ isotope systematics are observed, variations in ${ }^{18} \mathrm{O} /{ }^{16} \mathrm{O}$ ratios also can be used as an additional petrogenetic indicator and guide to magma source character and process 
because oxygen isotopes provide geochemical information that is complementary to that derived from trace elements and radiogenic isotopes. Table 5.2. O-isotope compostion of minerals and $\delta^{18} \mathrm{O}_{\text {magma }}$ values
calculatedfollowing the procedure of Bindeman et al. (2004).

\begin{tabular}{|c|c|c|c|c|c|c|c|}
\hline Sample & Rock type & $\delta{ }^{18} \mathrm{O}_{\mathrm{amp}}$ & 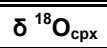 & 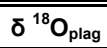 & $\overline{\mathrm{SiO}} \mathrm{Si}_{2}(\mathrm{wt} \%)$ & MgO (wt\%) & Calculated $\delta^{18} \mathrm{O}$ in melt ${ }^{\S}$ \\
\hline \multicolumn{8}{|c|}{ Soná-Azuero arc } \\
\hline $\begin{array}{l}\text { Pan-05-007 } \\
\end{array}$ & Andesite & 6.6 & N.D. & N.D. & 62.74 & 7.43 & N.D. \\
\hline Pan-05-008 & Dacite & 5.9 & N.D. & 7.8 & 63.12 & 6.85 & 7.0 \\
\hline Pan-05-017 & Dacite & 5.3 & N.D. & 8.3 & 67.82 & 4.28 & 6.7 \\
\hline \multicolumn{8}{|c|}{ Chagres-Bayano arc } \\
\hline Pan-03-004 & Microdiorite & 4.5 & N.D. & 7.2 & 54.99 & 4.63 & N.D. \\
\hline Pan-03-007 & Gabbro & 5.4 & N.D. & 4.7 & 49.49 & 7.20 & 5.7 \\
\hline Pan-03-014 & Andesite & 5.9 & N.D. & 7 & 62.34 & 2.40 & $7.10 \pm 0.14$ \\
\hline Pan-03-022 & Granodiorite & 3.6 & N.D. & 9.1 & 61.97 & 3.52 & N.D. \\
\hline Pan-03-023 & Andesite & 6.4 & N.D. & 9.9 & 62.96 & 2.68 & N.D. \\
\hline Pan-03-029 & Basalt. andesite & 5.5 & N.D. & 6 & 54.05 & 6.62 & $6.05 \pm 0.07$ \\
\hline Pan-04-004 & Andesite & 5.4 & N.D. & 7.4 & 59.42 & 3.31 & 6.3 \\
\hline Pan-04-011 & Granodiorite & 4.9 & N.D. & 7.4 & 61.57 & 3.05 & 5.9 \\
\hline Pan-06-100 & Microdiorite & 3.8 & N.D. & N.D. & 57.17 & 6.56 & N.D. \\
\hline Pan-06-103 & Andesite & 4.7 & N.D. & N.D. & 56.99 & 3.71 & N.D. \\
\hline Pan-06-104 & Segregation & 3.9 & N.D. & N.D. & 53.73 & 3.33 & N.D. \\
\hline Pan-06-206 & Granodiorite & 4.7 & N.D. & N.D. & 63.37 & 3.01 & 5.8 \\
\hline Pan-06-210 & Andesite & 5 & N.D. & N.D. & 61.07 & 3.54 & 6.0 \\
\hline \multicolumn{8}{|c|}{ Cordilleran arc } \\
\hline Pan-03-032 & Basalt. andesite & 6 & N.D. & 10.9 & 56.53 & 4.90 & N.D. \\
\hline Pan-05-031 & Andesite & N.D. & N.D. & 5.8 & 59.78 & 2.56 & 6.0 \\
\hline Pan-05-056 & Basalt. andesite & N.D. & N.D. & 6 & 53.11 & 4.33 & 6.0 \\
\hline Pan-05-066 & Basalt. andesite & N.D. & N.D. & 6.8 & 52.77 & 5.18 & N.D. \\
\hline Pan-06-023 & Diorite & 4.6 & N.D. & N.D. & 46.02 & 4.15 & N.D. \\
\hline Pan-06-068 & Andesite & 4.4 & N.D. & N.D. & 60.78 & 3.55 & N.D. \\
\hline Pan-06-125 & Ryolith & N.D. & N.D. & 7.1 & 77.17 & 0.23 & N.D. \\
\hline Pan-06-131 & Dacite & 4.9 & N.D. & N.D. & 64.10 & 1.85 & 6.1 \\
\hline Pan-06-185a & Granite & N.D. & N.D. & 3.9 & 67.30 & 1.45 & N.D. \\
\hline Pan-06-218 & Ryolith & N.D. & N.D. & 5.9 & 74.39 & 0.32 & 6.5 \\
\hline Pan-06-219 & Dacite & 5.2 & N.D. & N.D. & 64.28 & 1.91 & 6.4 \\
\hline \multicolumn{8}{|l|}{ Adakite suite } \\
\hline Pan-05-047 & Dacite & 5.5 & N.D. & 7.6 & 69.68 & 0.92 & $7.50 \pm 0.76$ \\
\hline Pan-05-049 & Dacite & 5.5 & N.D. & 6.8 & 70.57 & 0.76 & $7.20 \pm 0.14$ \\
\hline Pan-06-006 & Andesite & 5.1 & N.D. & N.D. & 59.93 & 3.33 & 6.0 \\
\hline Pan-06-010 & Dacite & 5.3 & N.D. & N.D. & 63.50 & 2.67 & 6.5 \\
\hline Pan-06-014 & Andesite & 4.9 & N.D. & N.D. & 57.21 & 3.30 & 5.7 \\
\hline Pan-06-043 & Dacite & 6.9 & N.D. & N.D. & 66.96 & 1.31 & N.D. \\
\hline Pan-06-044 & Dacite & 3.9 & N.D. & N.D. & 67.22 & 1.31 & N.D. \\
\hline Pan-06-073 & Dacite & 4.8 & N.D. & N.D. & 65.60 & 1.03 & 6.1 \\
\hline Pan-06-136 & Andesite & 5.1 & N.D. & N.D. & 60.32 & 2.93 & 6.1 \\
\hline Pan-06-137a & Andesite & 5.9 & 6.4 & 7.5 & 60.76 & 3.32 & $7.33 \pm 0.40$ \\
\hline Pan-06-137b & Andesite & 4.5 & N.D. & 7.3 & 60.46 & 3.46 & $6.5 \pm 1.41$ \\
\hline Pan-06-137d & Cndesite & 5.8 & 6.6 & 7.5 & 60.54 & 3.41 & $7.37 \pm 0.49$ \\
\hline Pan-06-138b & Dacite & 5.5 & N.D. & 6.4 & 65.48 & 2.02 & $6.75 \pm 0.07$ \\
\hline Pan-06-140 & Andesite & 5 & N.D. & N.D. & 58.23 & 4.74 & 5.8 \\
\hline Pan-06-141 & Basalt.andesite & N.D. & 5.4 & N.D. & 55.99 & 6.22 & 6.1 \\
\hline Pan-06-161 & Andesite & 5.5 & N.D. & N.D. & 60.82 & 3.24 & 6.5 \\
\hline Pan-06-165 & Andesite & 5.3 & 4.9 & N.D. & 61.13 & 3.00 & $6.1 \pm 0.28$ \\
\hline Pan-06-166 & Andesite & 5.2 & 5.5 & 7.3 & 58.84 & 3.54 & $6.65 \pm 0.68$ \\
\hline Pan-06-168 & Andesite & 5.2 & N.D. & N.D. & 60.87 & 3.35 & 6.2 \\
\hline Pan-06-169 & Andesite & 5.6 & N.D. & N.D. & 60.67 & 3.43 & 6.6 \\
\hline Pan-06-170 & Andesite & 5.7 & N.D. & N.D. & 59.88 & 3.58 & 6.6 \\
\hline Pan-06-173 & Andesite & 5.2 & 5.4 & N.D. & 59.46 & 3.33 & $6.20 \pm 0.14$ \\
\hline Pan-06-174 & Andesite & N.D. & 5.6 & N.D. & 57.55 & 4.13 & 6.4 \\
\hline Pan-06-175 & Andesite & 5 & 5.2 & 6.4 & 58.39 & 4.65 & $6.10 \pm 0.36$ \\
\hline Pan-06-176 & Andesite & 5.2 & 5.8 & 7.5 & 58.89 & 3.41 & $6.86 \pm 0.70$ \\
\hline Pan-06-177 & Andesite & 4.7 & 5.1 & 6.1 & 59.35 & 3.44 & $6.00 \pm 0.35$ \\
\hline Pan-06-179 & Andesite & 4.9 & N.D. & 6.3 & 61.13 & 3.10 & $6.35 \pm 0.21$ \\
\hline Pan-06-183 & Andesite & 4.6 & N.D. & 6.5 & 61.38 & 3.00 & $6.15 \pm 0.78$ \\
\hline Pan-06-184 & Andesite & N.D. & 6.3 & N.D. & 59.75 & 3.39 & 7.2 \\
\hline \multicolumn{8}{|c|}{$\begin{array}{l}8 \mathrm{Magma}{ }^{18} \mathrm{O} /{ }^{16} \mathrm{O} \text { ratios were estimated only for those instances where expected high-temperature fractions were observed for mineral } \\
\text { pairs or where minerals with measured } \delta^{18} \mathrm{O} \text { values that fall within the range expected for the unaltered host rock composition. Averages } \\
\text { and standard deviation values are given for multiple estimates of } \delta^{18} \mathrm{O}_{\text {magma }} \text { derived from two or three measured mineral } \delta^{18} \mathrm{O} \text { values. }\end{array}$} \\
\hline
\end{tabular}


Table 5.3. Ranges of $\delta^{18} \mathrm{O}$ variation for Panamanian igneous rocks.

\begin{tabular}{lcccccccc}
\hline \hline & No. & $\delta^{18} \mathrm{O}_{\text {amphibole }}$ & No. & $\delta^{18} \mathrm{O}_{\text {clinopyroxene }}$ & No. & $\delta^{18} \mathrm{O}_{\text {plagioclase }}$ & No. & $\delta^{18} \mathrm{O}_{\text {glass }}$ \\
\hline Soná-Azuero arc & 3 & 5.3 to 6.6 & N.D. & 2 & 7.8 to 8.3 & N.D. \\
Chagres-Bayano arc & 13 & 3.6 to 6.4 & N.D. & 8 & 4.7 to 9.9 & N.D. \\
Cordilleran arc & 5 & 4.4 to 6.0 & N.D. & 7 & 3.9 to 10.9 & 3 & 5.9 to 12.9 \\
Adakite suite & 26 & 3.9 to 6.9 & 11 & 4.9 to 6.6 & 12 & 6.1 to 7.5 & N.D. \\
\hline
\end{tabular}

To ascertain if measured ${ }^{18} \mathrm{O} /{ }^{16} \mathrm{O}$ ratios are pristine and have not been affected by secondary modification, measured $\delta^{18} \mathrm{O}$ values can be evaluated based on equilibrium mineral-mineral and mineral-melt O-isotope fractionations expected on the basis of theoretical considerations (Kieffer, 1982; Zheng, 1991, 1997; Zhao and Zheng , 2003; Bindeman et al. 2004) or laboratory experiments (Matthews et al., 1983; Chiba et al., 1989; Chacko et al., 2001). The ${ }^{18} \mathrm{O}$ content of a bulk rock, particularly fine-grained magmatic rocks or subvolcanic intrusives, can be readily modified by water-rock interactions both at high and low temperature (see e.g. Gregory et al., 1989). Radiogenic isotopes systems, particularly Sr, may also be affected by secondary alteration, if sufficiently intense. Most natural waters are ${ }^{18} \mathrm{O}$ deficient compared to magmatic silicate rocks. Thus, isotopic exchange as a consequence of water-rock interaction at high temperatures, where fractionation coefficients are small, will result in a lowering of rock $\delta^{18} \mathrm{O}$ values. By contrast, weathering and alteration in the near-surface environment will be characterized by strong ${ }^{18} \mathrm{O}$ enrichment because fractionation factors are large at low temperatures. A variety of studies have shown that most Tertiary and older volcanic rocks have elevated ${ }^{18} \mathrm{O} /{ }^{16} \mathrm{O}$ ratios as a consequence of hydration and weathering at Earth's surface (Muehlenbachs and Clayton, 1972; Taylor et al., 1984; Cerling et al., 1985; Harmon et al., 1987). Silicic glass and feldspar are the phases most susceptible to secondary alteration, but even minerals like amphibole and pyroxene can have their ${ }^{18} \mathrm{O} /{ }^{16} \mathrm{O}$ ratios modified through high degrees of water-rock interaction particularly at elevated temperature. Two approaches can be taken to ascertain whether measured ${ }^{18} \mathrm{O} /{ }^{16} \mathrm{O}$ ratios are pristine or have been affected by secondary modification.

Based on a careful screening of our data using predicted equilibrium fractionation, 56 of the 87 mineral separates analyzed (Table 5.2) have $\delta^{18} \mathrm{O}$ values that are considered to be representative of the magmas from which the minerals crystallized based upon measured ${ }^{18} \mathrm{O} /{ }^{16} \mathrm{O}$ ratios and mineral-pair fractionations. A group of 31 minerals are considered to have anomalously low or high ${ }^{18} \mathrm{O} /{ }^{16} \mathrm{O}$ ratios that indicate 


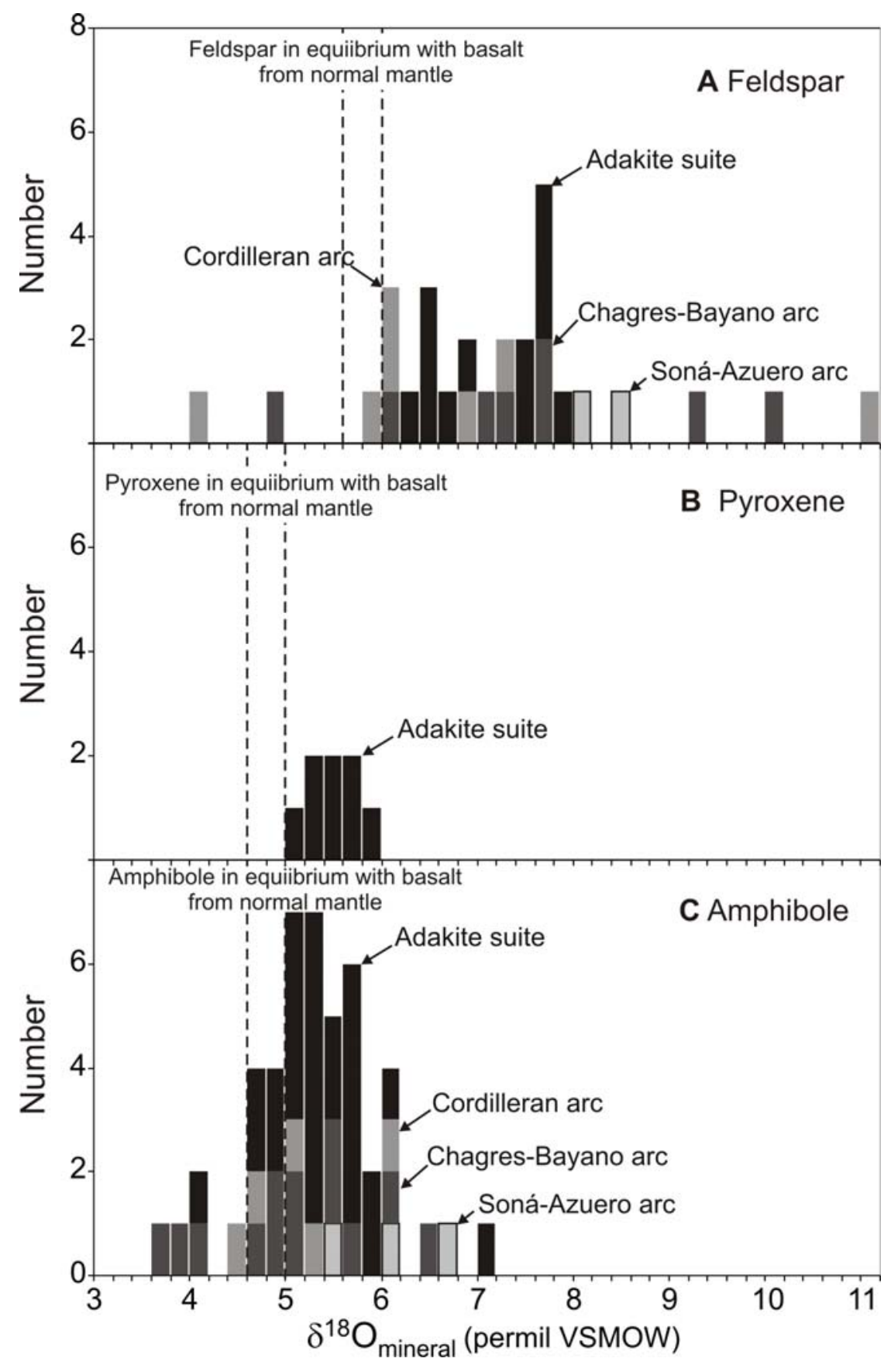

Figure 5.9. Histogram of $\delta^{18} \mathrm{O}$ values illustrating the O-isotope variation in $(A)$ feldspar, (B) pyroxene, and (C) amphibole for Panamanian igneous rocks. The dashed lines denote the field for the mineral in equilibrium with parental basalts generated within the mantle wedge in convergent plate margin subduction zone settings, from 5.6 to $6.0 \%$ for plagioclase and 4.6 to $5.0 \%$ for clinopyroxene and amphibole. A process of magmatic evolution through only closed-system fractionation will produce evolved rhyodacitic magmas from a basaltic parent magma that are enriched in ${ }^{18} \mathrm{O}$ by $\leq 1 \%$ (Matsuhisa, 1979; Harmon \& Gerbe, 1992; Bindeman et al., 2004). Feldspar crystallized under equilibrium from highly evolved rhyodacitic melts will be enriched in ${ }^{18} \mathrm{O}$ by $\sim 0.4 \%$ as compared with $\sim 1.5 \%$ for pyroxene and amphibole. VSMOW-Vienna standard mean ocean water. 
post-crystallization modification (Fig. 5.10). As expected, feldspar is the mineral most affected by post-crystallization alteration, with only five of the Soná-Azuero arc, Chagres-Bayano arc, and Cordilleran arc plagioclase separates having O-isotope ratios that fall within the $\delta^{18} \mathrm{O}$ range of $5.6 \%$ to $7.0 \%$ expected for normal subduction zone magmatic rocks The other 13 feldspars, independent of their age group or rock type, have lower or higher $\delta{ }^{18} \mathrm{O}_{\mathrm{pl}}$ values that are outside this range and indicative of post-crystallization secondary modification. Some of these feldspars have a cloudy appearance in thin section, consistent with this interpretation. Two samples (gabbro PAN-03-007 with $\delta^{18} \mathrm{O}_{\mathrm{pl}}=4.7 \%$ and granite PAN-06-185a with $\delta^{18} \mathrm{O}_{\mathrm{pl}}=3.9 \%$ ) have $\delta^{18} \mathrm{O}_{\mathrm{pl}}$ values below $5.5 \%$ that are indicative of high-temperature subsolidus hydrothermal alteration. Four other samples (dacite PAN-05-017 with $\delta^{18} \mathrm{O}_{\mathrm{pl}}=8.3 \%$, granodiorite PAN-03-022 with $\delta^{18} \mathrm{O}_{\mathrm{pl}}=9.1 \%$, andesite PAN-03-023 with $\delta^{18} \mathrm{O}_{\mathrm{pl}}=$ 9.9\%o, and basaltic andesite PAN-03-032 with $\delta^{18} \mathrm{O}_{\mathrm{pl}}=10.9 \%$ ) are strongly ${ }^{18} \mathrm{O}$ enriched with $\delta^{18} \mathrm{O}$ values elevated above $8 \%$ that have been produced by secondary alteration at low-temperature. Twelve samples have $\delta^{18} \mathrm{O}_{\mathrm{pl}}$ values in the intermediate range from between 7 and $8 \%$ that are more difficult to interpret. However, based upon either (i) a normal $\delta^{18} \mathrm{O}$ value for coexisting amphibole or (ii) a $\delta^{18} \mathrm{O}_{\mathrm{pl}}$ value higher than expected for the bulk composition of the host rock, these samples are considered to have not fully retained the original O-isotope signature so that magmatic $\delta^{18} \mathrm{O}$ values were not estimated for these samples from the measured feldspar ${ }^{18} \mathrm{O} /{ }^{16} \mathrm{O}$ ratios.

Matrix glass samples were analyzed for three Cordilleran arc volcanic rocks. Two of these samples, one from dacite PAN-06-041 with $\delta^{18} \mathrm{O}_{\mathrm{gl}}=8.4 \%$ and the other from PAN-06-218 with $\delta^{18} \mathrm{O}_{\mathrm{gl}}=12.9 \%$, exhibit strong ${ }^{18} \mathrm{O}$ enrichment as a consequence of low-temperature hydration. This is not surprising given the Miocene age and silicic composition of these glasses. The third glass sample, with $\delta^{18} \mathrm{O}_{\mathrm{gl}}=5.9 \%$, comes from basaltic andesite PAN-03-032. This sample contains strongly ${ }^{18} \mathrm{O}$-enriched feldspar with $\delta^{18} \mathrm{O}_{\mathrm{pl}}=10.9 \%$ that could only have been produced by postcrystallization alteration at low-temperature. The $\delta^{18} \mathrm{O}_{a m}=6.0 \%$, for the amphibole from this rock also has elevated relative to the normal basaltic-andesitic range, but to a far lesser extent than its companion feldspar. Thus, the O-isotopic composition of the glass, although appearing reasonable for such an arc lava with $\delta^{18} \mathrm{O}=5.9 \%$, must be considered suspect. 

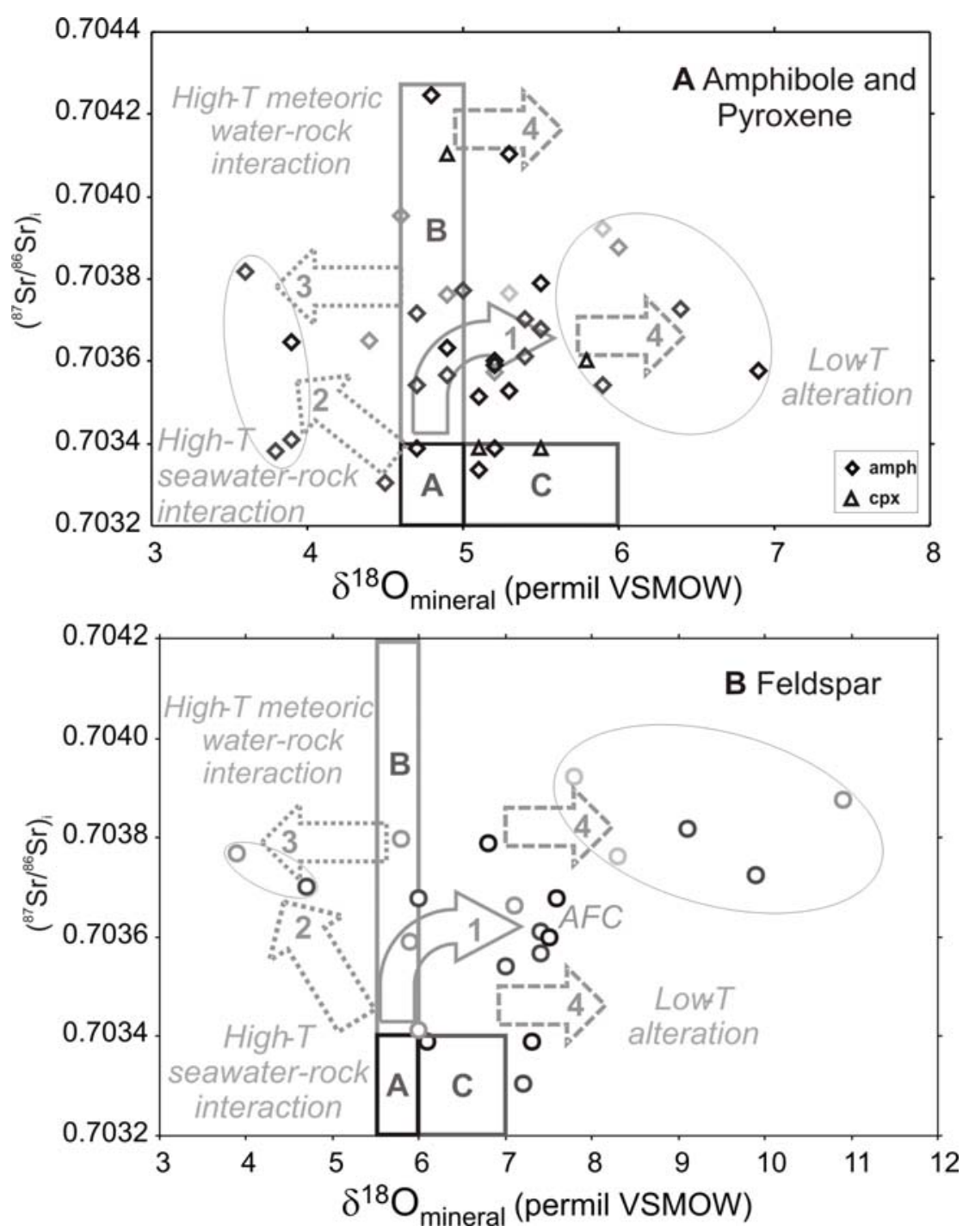

Figure 5.10. Plot of mineral ${ }^{87} \mathrm{Sr} /{ }^{86} \mathrm{Sr}$ versus $\delta^{18} \mathrm{O}$ for $(A)$ amphibole and pyroxene and $(B)$ feldspar for Panamanian igneous rocks. See text for explanation. The two circles in the figures bound samples that have had their O-isotopic compositions modified by high- and low-temperature secondary processes as indicated in the figure and discussed in the text. VSMOW-Vienna standard mean ocean water. amph-Amphibole; cpx-clinopyroxene.

In Figure $5.10,{ }^{87} \mathrm{Sr} /{ }^{86} \mathrm{Sr}$ ratios are plotted versus $\delta^{18} \mathrm{O}$ for amphibole and pyroxene $(A)$ and plagioclase (B). The field $(A)$ in each plot denotes the field for the mineral in equilibrium with normal arc parental basalt magmas having ${ }^{87} \mathrm{Sr} /{ }^{86} \mathrm{Sr}=0.7032-0.7034$ and $\delta^{18} \mathrm{O}=5.6-6.0 \%$. The area $(\mathrm{B})$ above the mantle magma field, bounded by the light grey lines in each plot, that extends to just above ${ }^{87} \mathrm{Sr} /{ }^{86} \mathrm{Sr}=0.7042$ denotes mantle source heterogeneity that produces ${ }^{87} \mathrm{Sr}$-enriched basaltic magmas with normal $\delta^{18} \mathrm{O}$ values. The introduction of seawater-derived fluids into the magma source also can elevate the ${ }^{87} \mathrm{Sr} /{ }^{86} \mathrm{Sr}$ ratio without affecting $\mathrm{O}-$-, $\mathrm{Nd}$-, or $\mathrm{Pb}$-isotope ratios. The two Adakite suite samples with the highest ${ }^{87} \mathrm{Sr} /{ }^{86} \mathrm{Sr}$ ratios (PAN-06-073 
and PAN-06-165) have a likely source from the subducted oceanic basalt that had been affected by such seawater alteration. The area $(C)$ to the right in each figure, indicated by the grey box, denotes the ${ }^{18} \mathrm{O}$ enrichment possible through closed system fractional crystallization from basalt to rhyodacitic compositions. Rhyolite PAN-06-218 with a feldspar $\delta^{18} \mathrm{O}$ value of $5.9 \%$ can be explained in this way. The different arrows indicate the sense of ${ }^{87} \mathrm{Sr} /{ }^{86} \mathrm{Sr}-\delta^{18} \mathrm{O}$ trends for process that can affect observed rock and mineral isotopic compositions. Combined assimilation-fractional crystallization (1) of parental magmas generate both ${ }^{87} \mathrm{Sr}$ - and ${ }^{18} \mathrm{O}$-enriched phenocrysts in evolved andesite-rhyolite magmas. Chagres-Bayano arc andesite PAN-03-023 with $\delta^{18} \mathrm{O}_{\text {magma }}=7.10 \pm 0.14 \%$ was likely a product of such an AFC (assimilation, fractionation, and crystalisation) process. Subsolidus high-temperature seawater-rock interaction (2) with sub-volcanic intrusives, or assimilation of such submarine hydrothermally altered crust, will result in concomitant ${ }^{18} \mathrm{O}$ depletion and ${ }^{87} \mathrm{Sr}$ enrichment. By contrast, subsolidus high-temperature interaction with meteoric hydrothermal water (3) will result in ${ }^{18} \mathrm{O}$ depletion but not affect ${ }^{87} \mathrm{Sr} /{ }^{86} \mathrm{Sr}$ ratios, whereas low-temperature alteration (4) will produce ${ }^{18} \mathrm{O}$ enrichment and not affect $\mathrm{Sr}$ isotope composition. The two circles in the figures bound samples that have had their isotopic compositions modified by secondary processes. It can be seen from Table 5.2 and Figure 5.10 that some samples characterized by O-isotope disequilibrium have been affected by high-temperature alteration (e.g. granite Pan-06-185a with $\delta^{18} \mathrm{O}_{\mathrm{pl}}=3.9 \%$ ) whereas others have been subjected to low-temperature alteration processes (e.g. basaltic andesite Pan-03-032 with $\delta^{18} \mathrm{O}_{\mathrm{pl}}=10.9 \%$ ).

About half of the Soná-Azuero arc, Chagres-Bayano arc, and Cordilleran arc amphiboles O-isotope compositions are consistent with a mantle derivation of their host magmas. Clearly, the amphibole in granodiorite PAN-03-022, with an anomalously low $\delta^{18} \mathrm{O}_{a m}$ value of $3.6 \%$, has been affected by subsolidus water-rock interaction at high-temperature, but to a lesser extent than the corresponding feldspar from the same rock. Samples PAN-06-100, PAN-06-044, and PAN-06-104 have similarly low $\delta^{18} \mathrm{O}_{\mathrm{am}}$ values of $3.8 \%$ and $3.9 \%$ o that also document extensive subsolidus hydrothermal alteration of these rocks. The same is likely the case for three other samples: andesite PAN-06-068, with $\delta^{18} \mathrm{O}_{a m}=4.4 \%$, and both microdiorite PAN-03-004 and granodiorite PAN-04-011, with respective $\delta^{18} \mathrm{O}_{a m}$ values of $4.4 \%$ and $4.9 \%$ and elevated feldspar $\delta^{18} \mathrm{O}$ values $>7 \%$. The degree of secondary alteration is lower for these rocks than for PAN-03-022. 
The amphibole $\delta^{18} \mathrm{O}$ value of $6.6 \%$ for Soná-Azuero arc andesite PAN-05-007 indicates that this sample has suffered a significant degree of low-temperature alteration and ${ }^{18} \mathrm{O}$ enrichment. The large $\Delta_{\mathrm{pl}-\mathrm{am}}$ values of $+1.9 \%$ and $+3.0 \%$ for the two Soná-Azuero arc dacites, PAN-05-008 and Pan-05-01, indicate that the Oisotope composition rocks is not pristine. With respective amphibole and feldspar $\delta^{18} \mathrm{O}$-values of $5.9 \%$ and $7.8 \%$ for PAN-05-008 and $5.3 \%$ and $8.3 \%$ for PAN-05-017, this alteration appears to have been of sufficiently low water-rock ratio that amphibole ${ }^{18} \mathrm{O} /{ }^{16} \mathrm{O}$ ratios were retained intact, while the feldspar ${ }^{18} \mathrm{O} /{ }^{16} \mathrm{O}$ ratios were elevated $\sim 1-2 \%$ as a consequence of low-temperature alteration. The magmatic $\delta^{18} \mathrm{O}$ values estimated from the amphibole ${ }^{18} \mathrm{O} /{ }^{16} \mathrm{O}$ ratios for these two compositionally evolved lavas are $6.7 \%$ and $7.0 \%$, respectively.

For the Chagres-Bayano arc, six samples have O-isotope systematic that yield reliable estimates of magmatic $\mathrm{O}$-isotope composition. With respective $\delta^{18} \mathrm{O}_{\mathrm{am}}$ and $\delta^{18} \mathrm{O}_{\mathrm{pl}}$ values of $5.5 \%$ and $6.0 \%$, and a $\delta^{18} \mathrm{O}_{\mathrm{pl}-\mathrm{am}}$ value of $+0.5 \%$, basaltic andesite PAN-03-029 had a parental magma $\delta^{18} \mathrm{O}$ value of $6.05 \pm 0.07 \%$. Very slightly lower magma $\delta^{18} \mathrm{O}$ values of $5.7 \%$ and $5.9 \%$ are estimated for gabbro PAN-03-007 and granodiorite PAN-04-011 on the basis of their amphibole ${ }^{18} \mathrm{O} /{ }^{16} \mathrm{O}$ ratios. Three compositionally evolved Chagres-Bayano arc andesites (PAN-03-023, PAN-04-004, and PAN-06-210 with $\mathrm{SiO}_{2}$ contents between 59 and $62 \mathrm{wt} \%$ ) have $\delta^{18} \mathrm{O}_{\text {magma values }}$ ranging from 6.0 to $7.10 \pm 0.14 \%$. The feldspar ${ }^{18} \mathrm{O} /{ }^{16} \mathrm{O}$ ratios for all Chagres-Bayano arc samples except basaltic andesite PAN-03-029 have been elevated by low temperature alteration.

The only Cordilleran arc sample for which it was possible to separate both amphibole and feldspar is basaltic andesite PAN-03-032. With respective amphibole and plagioclase $\delta^{18} \mathrm{O}$ values of $6.0 \%$ and $10.9 \%$, and a $\delta^{18} \mathrm{O}$ plamp value of $+4.9 \%$, PAN03-032 documents a significant degree of isotopic modification as a result of lowtemperature secondary alteration. For the ten other Cordilleran arc samples, either amphibole or feldspar was analyzed. Two volcanic rocks also exhibit a modest level of $\delta{ }^{18} \mathrm{O}_{\mathrm{pl}}=6.8 \%$ and rhyolite PAN-06-125 with $\delta^{18} \mathrm{O}_{\mathrm{pl}}=7.1 \%$. By contrast, two samples from Cordilleran arc intrusive rocks and one volcanic sample have been affected by subsolidus water-rock interaction at elevated temperature, diorite PAN06-023 with $\delta^{18} \mathrm{O}_{\mathrm{am}}=4.6 \%$, andesite PAN-06-068 with $\delta^{18} \mathrm{O}_{\mathrm{am}}=4.4 \%$, and granite PAN-06-185 with $\delta^{18} \mathrm{O}_{a m}=3.9 \%$. Magmatic $\delta^{18} \mathrm{O}$ values falling within the narrow range from $6.0 \%$ to $6.5 \%$ could be estimated for five Cordilleran arc samples: 
basaltic andesite PAN-05-56 with $\delta^{18} \mathrm{O}_{\mathrm{pl}}=6.0 \%$, andesite PAN-05-031 with $\delta^{18} \mathrm{O}_{\mathrm{pl}}=$ $5.8 \%$, dacite PAN-06-131 with $\delta^{18} \mathrm{O}_{a m}=4.9 \%$, and rhyolite PAN-06-218 with $\delta^{18} \mathrm{O}_{p l}=$ $5.2 \%$.

More O-isotope data are available for the Adakite suite because it was possible to separate amphibole from most samples as well as clinopyroxene and feldspar from some rocks. Based on their young age, we have calculated magmatic $\delta^{18}$ Ovalues for all but two of the 29 Adakite suite samples (see below). The least evolved adakite sample, basaltic andesite PAN-06-141, has a $\delta^{18} \mathrm{O}_{\mathrm{cpx}}$ value of $5.4 \%$, which yields a magmatic $\delta^{18} \mathrm{O}$ value of $6.1 \%$ that is consistent with a normal subduction zone mantle origin. Another eight andesites (PAN-06-141, PAN-06-140, PAN-06-175, PAN-06-177, PAN-06-173, PAN-06-006, PAN-06-136, and PAN-06-165) and a dacite (PAN-06-073) have magmatic $\delta^{18} \mathrm{O}$ values that fall between 5.7 to $6.2 \%$ indicative of a similar origin. By contrast, the remainder of the Adakite sample suite of 13 andesites and four dacites exhibit surprisingly variable magmatic ${ }^{18} \mathrm{O} /{ }^{16} \mathrm{O}$ ratios that vary more than $1 \%$ from $\delta^{18} \mathrm{O}=6.4 \%$ to $7.5 \%$ and exhibit the same characteristic ${ }^{18} \mathrm{O}$ enrichment observed for adakitic lavas globally (Fig. 5.11) that were originally described by Abratis and Wörner (2001) and Bindeman et al. (2005). The four Panamanian adakites analyzed by Bindeman et al. (2005) have magmatic $\delta^{18} \mathrm{O}$ values of between 6.4 and $6.9 \%$, which fall toward the center of the $5.7 \%$ to $7.5 \%$ o $\delta^{18} \mathrm{O}$ distribution determined here for 27 samples.

Two samples, PAN-06-043 and PAN-06-044, are compositionally akin to the other dacitic Adakite suite lavas analyzed except that they have unusually high and low $\delta^{18} \mathrm{O}_{\mathrm{am}}$ values of $6.9 \%$ and $3.9 \%$, respectively. These anomalous O-isotopic compositions for phenocrysts in fresh young lavas are difficult to explain, but may offer critical insight into the petrogenesis of the Panamanian adakites. Adakites are widely considered to be the result of melting the subducting slab (Kay, 1978; Defant and Drummond, 1990; Stern and Kilian, 1996). Bindeman et al. (2005) have argued that adakites from convergent plate margin settings with modest enrichments in ${ }^{18} \mathrm{O}$ and ${ }^{87} \mathrm{Sr}$, like those from Panama and Fiji, may be generated through melting of the ${ }^{18} \mathrm{O}$ enriched upper portion of the subducting slab. Since the unusual O-isotope values in Central American adakites are related to strongly elevated Sr-isotope compositions at constant and high Nd-isotope ratios (Abratis, 1998) this signature is considered a clear indication for melting of seawater-altered basaltic rocks within the subducting slab. 


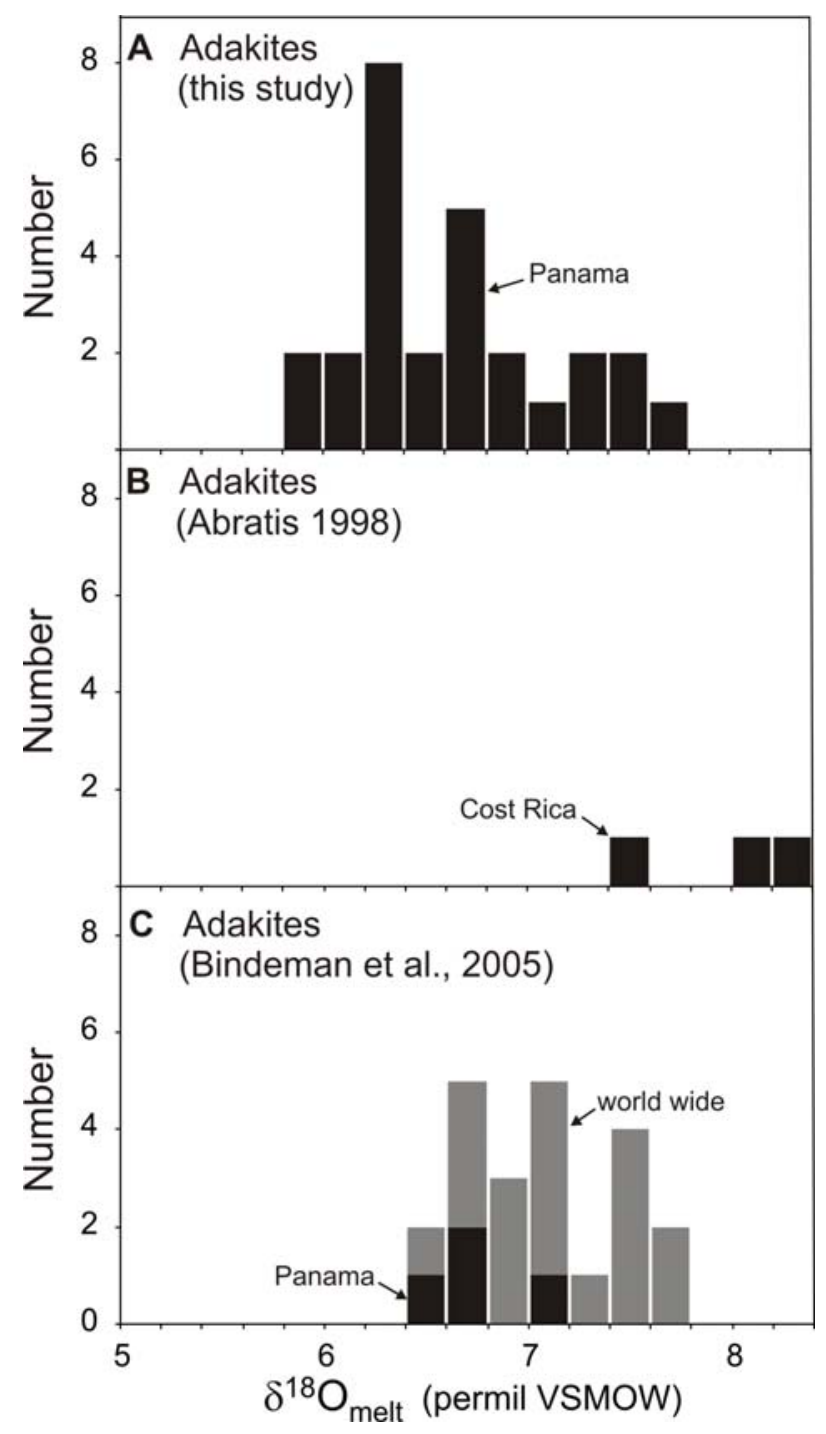

Figure 5.11. Histogram comparing $\delta^{18} \mathrm{O}$ values Panamanian adakites $(A)$ with those from Costa Rica (B) analyzed by Abratis (1998) and various locations worldwide including Panama (C) analyzed by Bindeman et al. (2005). VSMOW-Vienna standard mean ocean water.

The broad range of O-isotope ratios observed here for the Panamanian Adakite suite, with $\delta^{18} \mathrm{O}_{\text {magma }}=5.7 \%$ to $7.5 \%$, and the two adakite amphiboles with anomalously high and low $\delta^{18} \mathrm{O}_{\mathrm{am}}$ values of $6.9 \%$ and $3.9 \%$, suggests melting occurred throughout the slab, with both the upper ${ }^{18} \mathrm{O}$-enriched and lower ${ }^{18} \mathrm{O}$ depleted zones of the hydrothermally altered basaltic ocean crust involved in the melting process.

\subsubsection{Temporal History of Radiogenic Isotope Variations}

The radiogenic isotopic data are listed in Tables 5.4 and 5.5 and plotted as a function of sample age in Figure 5.12. Since a careful screening was performed based on the 
O-isotope data to identify samples affected by post-crystallization alteration, we will now consider in the discussion and interpretation of the radiogenic isotopes that follows only those samples identified to be pristine. A clear temporal trend is observed for $\mathrm{Nd}$-isotope ratios (Fig $5.12 \mathrm{~A}$ ), with ${ }^{143} \mathrm{Nd} /{ }^{144} \mathrm{Nd}$ for the different groups progressively increasing over the past 71 million years. The two Soná-Azuero arc samples have low and uniform Nd-isotope ratios of $0.512864 \pm 5$ and $0.512866 \pm 4$. The Chagres-Bayano arc suite displays a larger Nd-isotope variation from 0.512929 \pm 4 to $0.512853 \pm 4$, consistent with large variations in HFSE, distinctly higher compared to the Soná-Azuero arc and Cordilleran arc groups. The Cordilleran arc has Nd-isotope ratios from $0.513000 \pm 3$ to $0.512963 \pm 8$ that are significantly higher than those for the Chagres-Bayano arc. The Adakite suite displays a narrow but high range of ${ }^{143} \mathrm{Nd} /{ }^{144} \mathrm{Nd}$ ratios from $0.513016 \pm 9$ to $0.512951 \pm 4$. This progressive increase in ${ }^{143} \mathrm{Nd} /{ }^{144} \mathrm{Nd}$ ratios over the course of the past 71 million years indicates a more depleted mantle wedge composition through time with respect to $\mathrm{Sm} / \mathrm{Nd}$ during the evolution of the Central American arc. Similarly, an increase through time toward more radiogenic lead is observed for both ${ }^{206} \mathrm{~Pb} /{ }^{204} \mathrm{~Pb}$ and ${ }^{208} \mathrm{~Pb} /{ }^{204} \mathrm{~Pb}$ ratios (Figs. 5.12B, and 5.12C). There is a large difference in $\mathrm{Pb}$-isotope composition between Soná-Azuero arc and Chagres-Bayano arc samples, especially for ${ }^{206} \mathrm{~Pb} /{ }^{204} \mathrm{~Pb}$ ratios, whereas the Chagres-Bayano arc and Cordilleran arc samples are of similar $\mathrm{Pb}$ isotopic composition. The Soná-Azuero arc has $l o w{ }^{206} \mathrm{~Pb} /{ }^{204} \mathrm{~Pb}$ ratios of $18.65 \pm 0.01$ and $18.53 \pm 0.008$. The Chagres-Bayano arc lavas show distinctly higher values from $19.04 \pm 0.002$ to $18.78 \pm 0.007$. The Cordilleran arc is more homogeneous with ${ }^{206} \mathrm{~Pb} /{ }^{204} \mathrm{~Pb}$ ratios ranging from $19.03 \pm 0.008$ to $18.96 \pm 0.003$. The Adakite suite displays the highest $\mathrm{Pb}$-isotope ratios and largest variation, with ${ }^{206} \mathrm{~Pb} /{ }^{204} \mathrm{~Pb}$ ratios ranging from $19.34 \pm 0.005$ to $18.89 \pm 0.003$.

The temporal trends for ${ }^{207} \mathrm{~Pb} /{ }^{204} \mathrm{~Pb}$ and ${ }^{87} \mathrm{Sr} /{ }^{86} \mathrm{Sr}$ are not as distinct as those for the other radiogenic isotope systems (Figs. 5.12D, 5.12E). On average, ${ }^{207} \mathrm{~Pb} /{ }^{204} \mathrm{~Pb}$ ratios are similar in all groups. Variation is again largest for the Adakite suite, mainly due to the high ${ }^{207} \mathrm{~Pb} /{ }^{204} \mathrm{~Pb}$ ratios of PAN-06-165 and PAN-06-006. The ${ }^{87} \mathrm{Sr} /{ }^{86} \mathrm{Sr}$ ratios exhibit an initial decline from Soná-Azuero arc to Chagres-Bayano arc to the oldest Cordilleran arc samples, but then trend toward a partial enrichment in ${ }^{87} \mathrm{Sr}$ in the youngest Cordilleran arc rocks. For the Adakite suite, samples PAN-06-165 and PAN-06-073 again contribute to the large Sr-isotopic variation of the Adakite suite samples. 


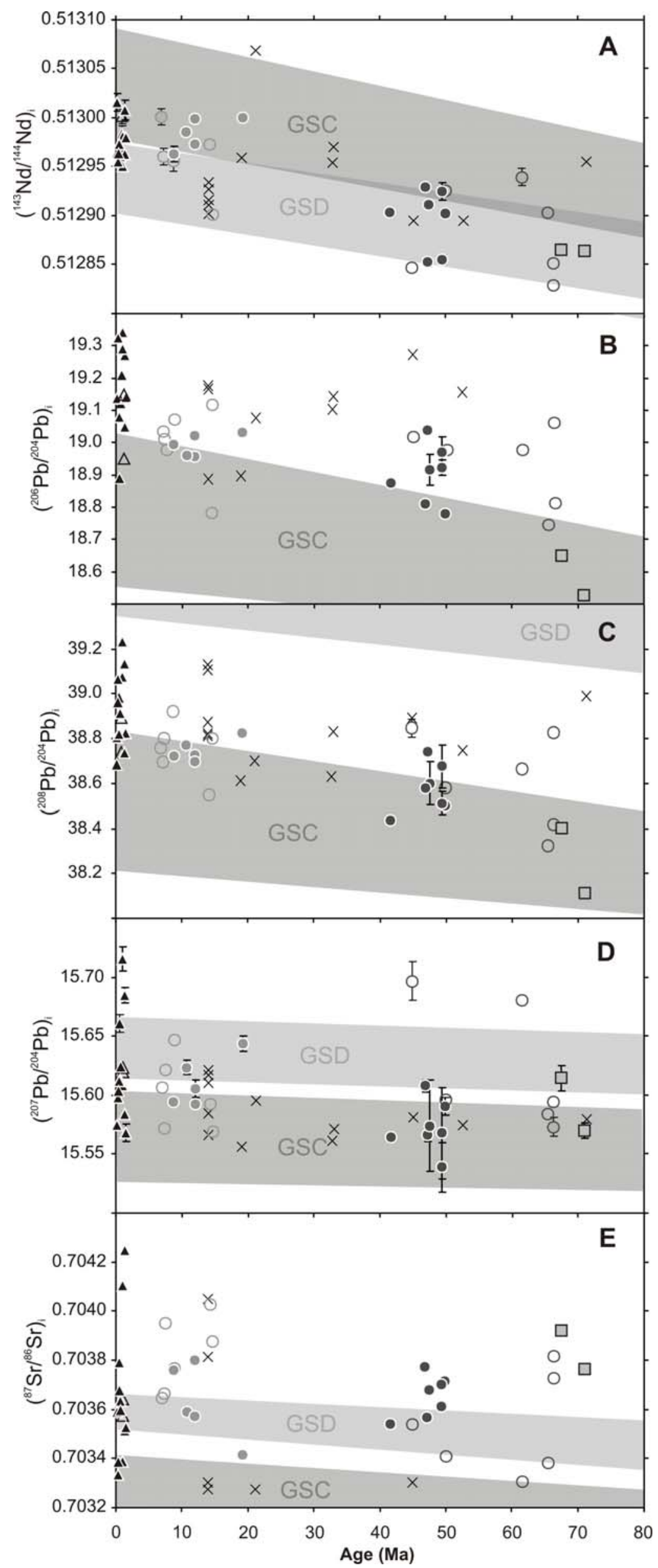


Figure 5.12 (privious page). (A-E) Plot of $\mathrm{Pb}$-, $\mathrm{Nd}$-, and Sr-isotope ratios for igneous rocks from central and western Panama over the past 80 million years. Open symbols are altered samples based on mineral $\delta^{18} \mathrm{O}$ values. The light- grey field shows references data for the GSC-Galápagos spreading center (compilation from the PetDB [Petrological Database of the ocean floor]: http://www.petdb.org/petdbWeb/search/download_pg.jsp), and the dark-grey field shows reference data for the southern Galápagos domain defined by Hoernle et al. (2000) together with data from White et al. (1993). Isotopic evolution has been calculated back in time. Due to a lack of $U$, Th and $P b$ concentrations for the Galápagos data, we followed the method of Hauff et al. (2000a) assuming a linear increase with ${ }^{206} \mathrm{~Pb} /{ }^{204} \mathrm{~Pb}\left(\mu=10^{* 206} \mathrm{~Pb} /{ }^{204} \mathrm{~Pb}-175\right)$ and ${ }^{232} \mathrm{Th} /{ }^{238} \mathrm{U}=3$ to allow for comparison of magma sources. Crosses represent data for rocks from accreted hotspot track from Sadofsky et al. (2009) and Hoernle et al. (2002).

Figure 5.12 also shows reference fields for the Galápagos spreading center (GSC) from the Petrological Database of the ocean floor (PetDB) and the Galápagos southern domain (GSD) from White et al. (1993) as defined by Hoernle et al. (2000). In order to compare magma sources through time radiogenic isotopic evolution has been calculated back in time. Due to a lack of $\mathrm{U}$, Th and $\mathrm{Pb}$ concentrations for the Galápagos data, we followed the method of Hauff et al. (2000a) and assumed a linear increase of $\mu$ with ${ }^{206} \mathrm{~Pb} /{ }^{204} \mathrm{~Pb}\left(\mu=10^{\star 206} \mathrm{~Pb} /{ }^{204} \mathrm{~Pb}-175\right)$ and ${ }^{232} \mathrm{Th} /{ }^{238} \mathrm{U}=3$. In addition, data for rocks of accreted terranes from the hotspot tracks outboard of Central America are also plotted (Sadofsky et al. 2009, Hoernle et al. 2002). Where clear differences exist for ${ }^{206} \mathrm{~Pb} /{ }^{204} \mathrm{~Pb}$ and ${ }^{208} \mathrm{~Pb} /{ }^{204} \mathrm{~Pb}$ ratios between GSC and GSD, Panama magmas sources are intermediate or displaced from GSC toward GSD indicating that the Galápagos southern domain may have been an important source component throughout the entire magmatic history of central and western Panama from as early as $66 \mathrm{Ma}$. It is clear from the unsystematic scatter of Sr-isotope ratios, and in particular their higher values relative to both GSD and GSC (Fig. 5.12), that some Sr-isotope compositions have been affected by seawater, either by introduction to their source or as a consequence of rock alteration after formation. Radiogenic isotopes are presented in Figure 5.13 together with reference data for MORB from the southern Eastern Pacific Rise (EPR) and from the Galápagos spreading center (GSC) from literature sources (from the PetDB). Data for the hotspot tracks are taken from Sadofsky et al. (2009) and Hoernle et al. (2002) and for the active Central American arc from Carr et al. (2003), Feigenson et al. (2004), and Hoernle et al. (2008). The global subducted sediment (GLOSS) field is from Plank and Langmuir (1998) and the local sediment field is form Sadofsky et al. (2009) and Feigenson et al. (2004). 
Table 5.4. Initial and measured Sr- and Nd-isotopic composition for separated minerals.

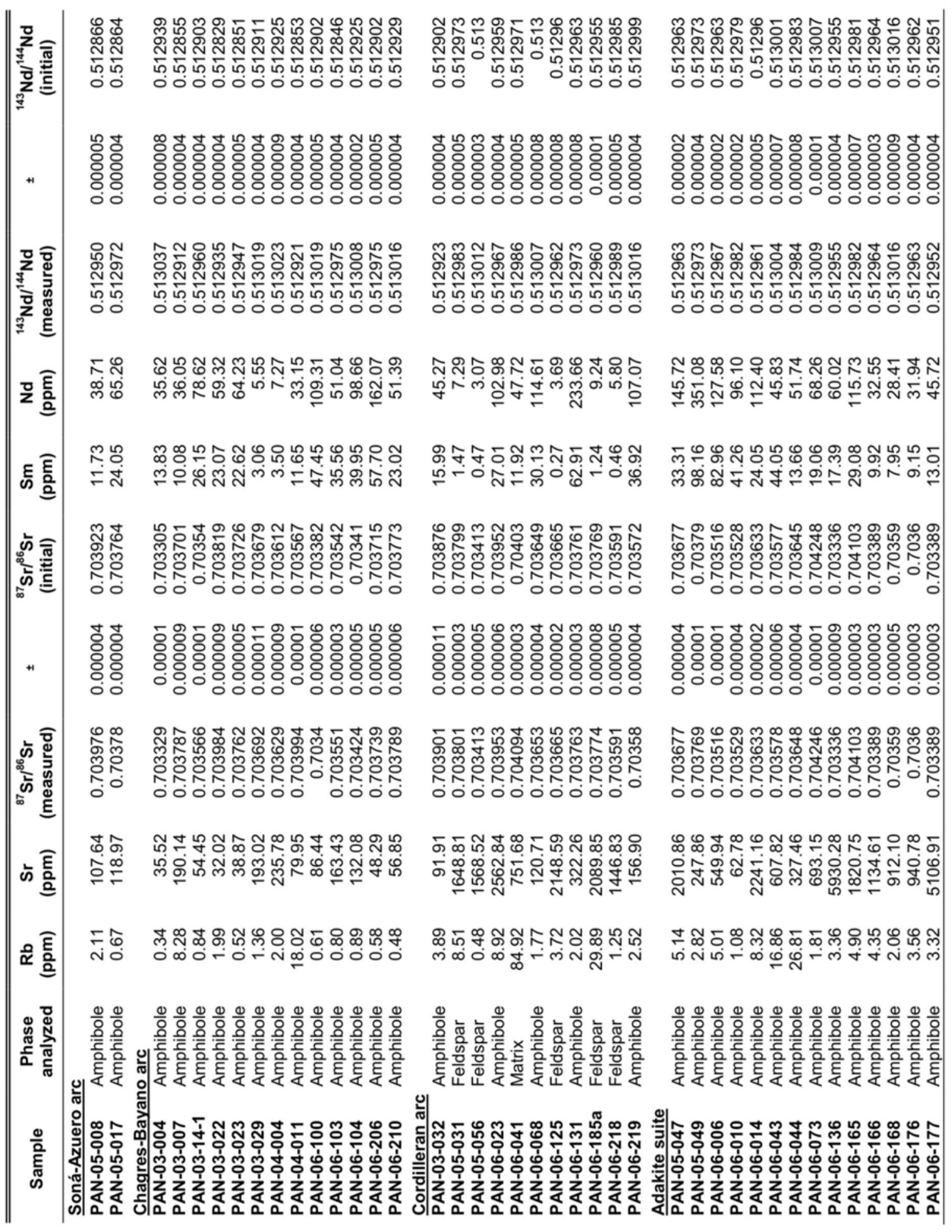


Table 5.5. Initial and measured Pb-isotopic composition for separated minerals.

\begin{tabular}{|c|c|c|c|c|}
\hline 2 & $\underset{\substack{\infty \\
\infty}}{\stackrel{m}{\infty}=\infty}$ & 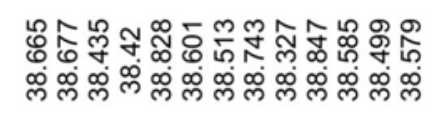 & 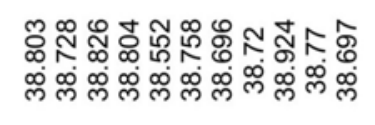 & 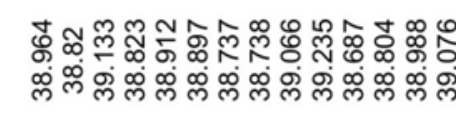 \\
\hline & เ్రి: & 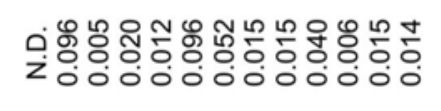 & 凤 & 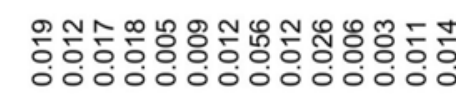 \\
\hline & 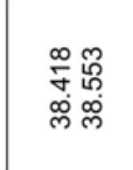 & 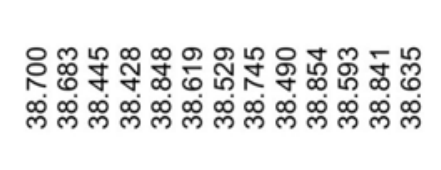 & 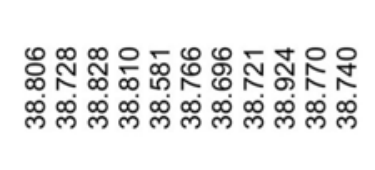 & 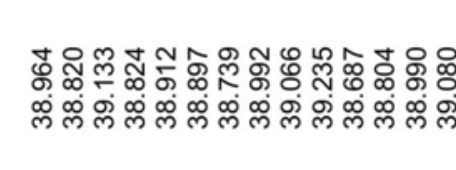 \\
\hline & 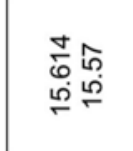 & 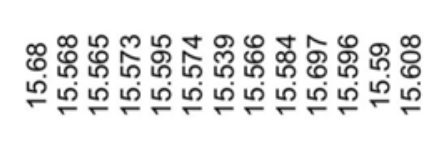 & 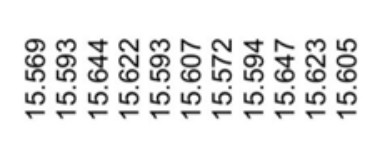 & 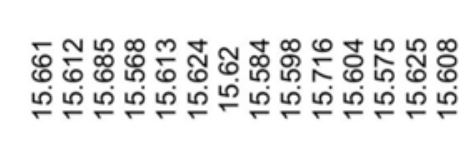 \\
\hline+1 & 웅유. & 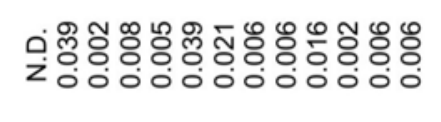 & 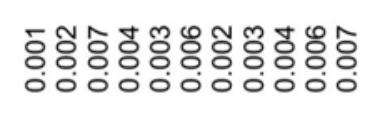 & 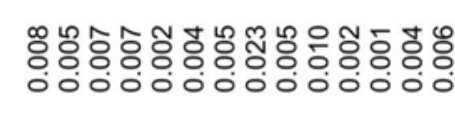 \\
\hline 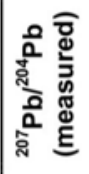 & 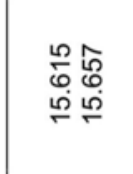 & 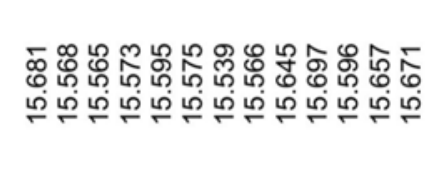 & 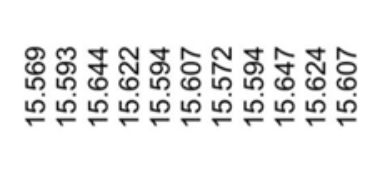 & 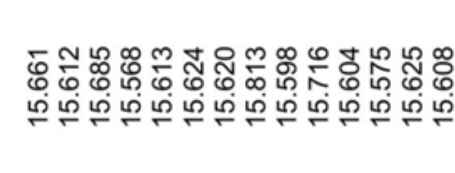 \\
\hline & 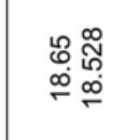 & 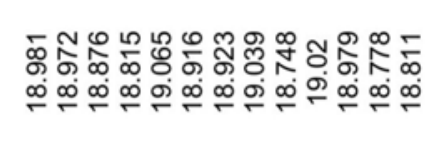 & 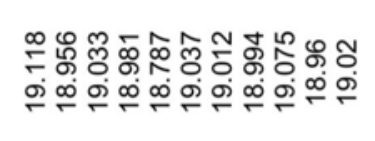 & 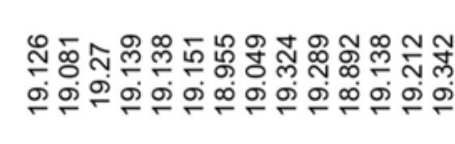 \\
\hline+1 & 당임 & 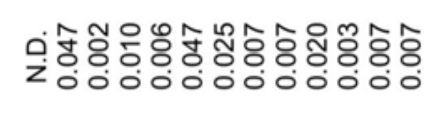 & 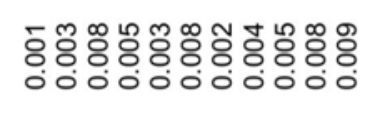 & 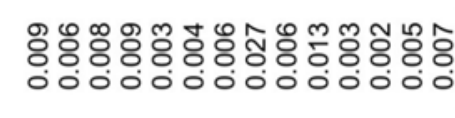 \\
\hline$\frac{1}{0}$ & 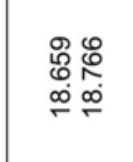 & 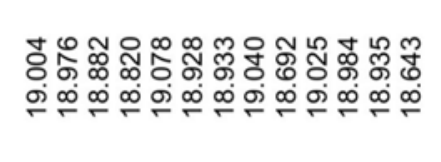 & 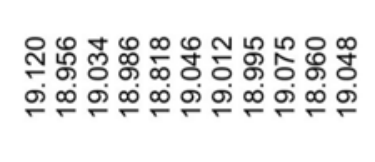 & 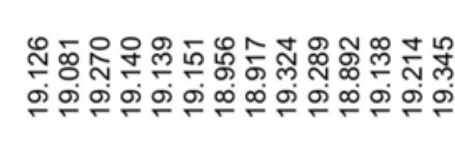 \\
\hline 8 & gृ & 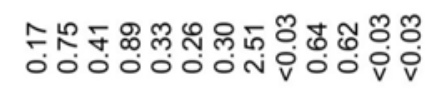 & 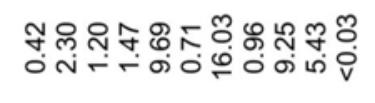 & 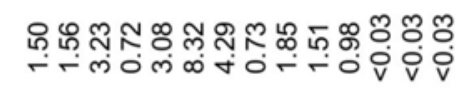 \\
\hline$\varepsilon \bar{\varepsilon}$ & mo & 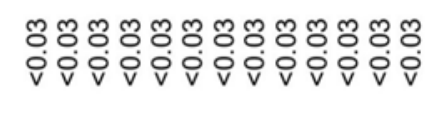 & 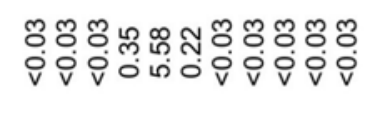 & 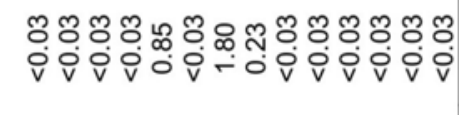 \\
\hline$>$ 흘 & - & 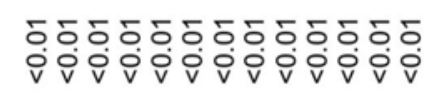 & 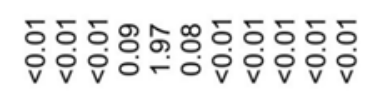 & 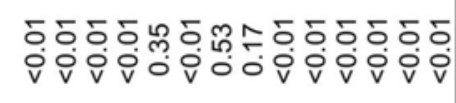 \\
\hline $\begin{array}{l}\bar{\pi} \\
\frac{\pi}{\mathbb{d}} \\
\frac{\pi}{\pi}\end{array}$ & 응을 & 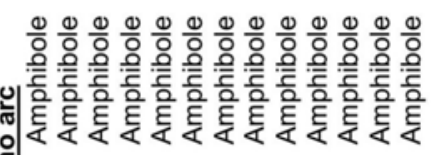 & 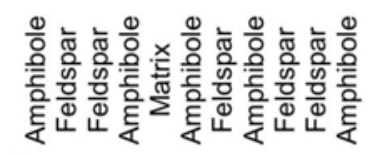 & 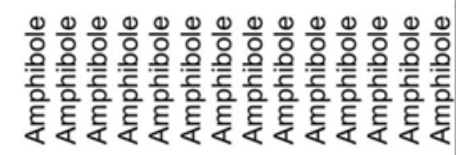 \\
\hline घ & 装 & & & \\
\hline
\end{tabular}


The Caribbean large igneous province data are from Kerr et al. $(1997,2002)$ and Hauff et al. (2000a, 2000b). Initial isotope ratios were calculated based on parent/daughter ratios of $\mathrm{Rb} / \mathrm{Sr}, \mathrm{Sm} / \mathrm{Nd}$ and $\mathrm{U} / \mathrm{Pb}$ and $\mathrm{Th} / \mathrm{Pb}$ measured by ICP-MS for single crystal aliquots from each sample. The mean error for $\mathrm{Rb} / \mathrm{Sr}$ is $7 \%$ and for $\mathrm{Sm} / \mathrm{Nd} 6 \%$. $U$ and Th for most samples were below the detection limit of $0.01 \mathrm{ppm}$ for $U$ and $0.03 \mathrm{ppm}$ for Th for ICP-MS. Therefore we used these values as upper boundary for $\mathrm{U}$ and $\mathrm{Th}$ and $\mathrm{Pb}$ as measured for our initial calculation. The differences between measured and initial values are negligible for most samples, except for eight samples that have particularly low values of $\mathrm{Pb}$.

The ${ }^{143} \mathrm{Nd} /{ }^{144} \mathrm{Nd}-{ }^{87} \mathrm{Sr} /{ }^{86} \mathrm{Sr}$ plot (Fig. 5.13A) and the ${ }^{143} \mathrm{Nd} /{ }^{144} \mathrm{Nd}^{206} \mathrm{~Pb} /{ }^{204} \mathrm{~Pb}$ plot (Fig. $5.13 \mathrm{~B}$ ) both show clearly that the Chagres-Bayano arc has a radiogenic isotopic character that is similar to the Caribbean large igneous province. The two ChagresBayano arc samples PAN-03-007 and PAN-04-011 with low ${ }^{143} \mathrm{Nd} /{ }^{144} \mathrm{Nd}$ have pristine $\delta^{18} \mathrm{O}_{\text {melt }}$ values only slightly above the mantle reference value $(5.6 \% \pm 0.2 \%)$. This indicates that the low ${ }^{143} \mathrm{Nd} /{ }^{144} \mathrm{Nd}$ signature observed for the Chagres-Bayano arc rocks is a source signal and not a result of assimilation in the arc crust. The displacement of the Panama field toward GLOSS and the local sediments in Figure 5.13 is likely caused by subducted sediment melts in the Chagres-Bayano arc source, a feature that is consistent with the variable HFSE contents and Th/La ratios of Chagres-Bayano arc magmas. These sediments, however, would have to have been relatively nonradiogenic with respect to $\mathrm{Pb}$ isotopes (Fig. 5.13D and 5.13E). The Soná-Azuero arc is very similar isotopically in the ${ }^{143} \mathrm{Nd} /{ }^{144} \mathrm{Nd}-{ }^{87} \mathrm{Sr} /{ }^{86} \mathrm{Sr}$ plot (Fig. $5.13 \mathrm{~A}$ ), but it is clearly less radiogenic than the Chagres-Bayano arc in terms of its $\mathrm{Pb}$-isotope composition (Fig. 5.13D and 5.13E). Caribbean large igneous province rocks are enriched in ${ }^{87} \mathrm{Sr}$, probably as a consequence of seawater interaction or possibly a contribution from subducted sediments (low ${ }^{143} \mathrm{Nd} /{ }^{144} \mathrm{Nd}$ subfield in Fig. 5.13A). Most probably, Caribbean large igneous province and Chagres-Bayano arc magmas were derived from a source that contained a mixture of depleted MORB mantle (DMM) and an enriched, slab component such as subducted sediments and/or melts thereof. In terms of their $\mathrm{Nd}$ - and Sr-isotope compositions (Fig. 5.13A), the Cordilleran arc samples plot into the Central American arc and Caribbean large igneous province fields. The higher ${ }^{143} \mathrm{Nd} /{ }^{144} \mathrm{Nd}$ values for the Cordilleran arc and Adakite suite compared to the Soná-Azuero arc and Chagres-Bayano arc probably 
reflect a more primitive mantle source in a less mature arc system that had been affected by a lower degree of slab component enrichment.
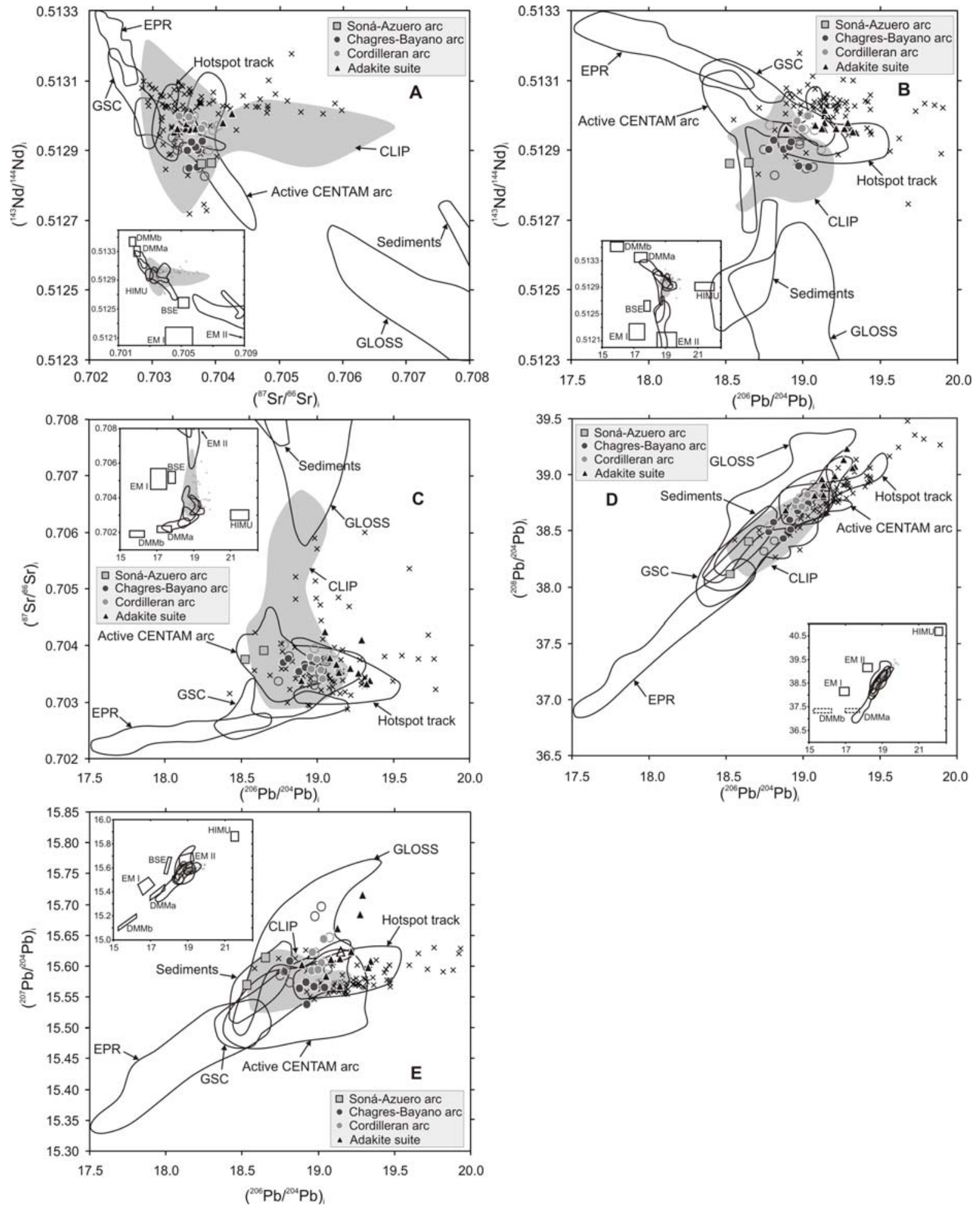

Figure 5.13. Plots of initial $\mathrm{Sr}$-, $\mathrm{Nd}$ - and $\mathrm{Pb}$ - isotope ratios for magmatic rocks of western and central Panama (A-E) together with reference fields for initial and measured Caribbean large igneous province (CLIP) (data from Kerr et al., 1997, 2002; Hauff et al., 2000a). GLOSS-Global Subducted Sediment (Plank \& Langmuir, 1998); sediment-local sediments (Sadofsky et al., 2009; Feigenson et al., 2004); 
active CENTAM arc-active central American arc (Carr et al., 2003; Feigenson et al., 2004; Hoernle et al., 2008), EPR-East Pacific Rise; GSC - Galápagos spreading center (both from the PetDB [Petrological Database of the ocean floor], http://www.petdb.org/petdbWeb/search/download_pg.jsp), and the initial hotspot track data (Sadofsky et al., 2009; Hoernle et al., 2002). The reference field for Caibbean large igneous province is subdivided into two parts: a grey shaded-initial values and grey crosses-measured values. The insert on each figure shows the data relative to the mantle reference fields (Zindler and Hart, 1986) for depleted mantle-DMMa and DMMb; enriched mantle-EMI and EMII; bulk silicate earth-BSE; and the enriched Pb reservoir-HIMU. Open symbols are altered samples based on mineral $\delta^{18} \mathrm{O}$ values. Analytical uncertainty is smaller than the size of data symbols.

In ${ }^{143} \mathrm{Nd} /{ }^{144} \mathrm{Nd}$ versus ${ }^{206} \mathrm{~Pb} /{ }^{204} \mathrm{~Pb}$ space (Fig. 5.13B), the Cordilleran arc plots largely coincident with the Central American arc and accreted OIB fields, whereas the Adakite suite closely follows the trend of the hotspot track samples and their plume mantle source. The Adakite suite consists of the Panama samples that have the most radiogenic $\mathrm{Pb}$-isotopic composition (Fig 5.13D and 5.13E) and thus most directly reflect the melting of Caribbean large igneous province basement or subducted Galápagos seamount basalts, both of which would carry the Galápagos plume source signature (Abratis and Wörner, 2001; Bindeman et al., 2005). Lavas of the Adakite suite also are enriched in ${ }^{18} \mathrm{O}$, with $\delta^{18} \mathrm{O}$ values up to $7 \%$, a feature that suggests a magma source component that was strongly affected by low-temperature seawater alteration. Significant crustal input (i.e. sediment subduction or assimilation) is not consistent with the relatively high and uniform Adakite suite ${ }^{143} \mathrm{Nd} /{ }^{144} \mathrm{Nd}$ ratios. Overall, our sample suite can be described in terms of four geochemical components, each of which contributed to arc magmatism in Panama during the past $71 \mathrm{Ma}$. It is noteworthy that Soná-Azuero arc rocks, which represent the onset of subduction at the western margin of the Caribbean large igneous province plateau, show the highest sediment component, whereas the young Adakite suite magmatism has the strongest signature from a (seawatermodified) Galápagos source with only minor sediment addition. The Chagres-Bayano arc and Cordilleran arc samples fall between these two end-member situations and mix toward a depleted mantle. Three mantle components have contributed to Panamanian magmatism: (1) depleted asthenospheric mantle that is present in all groups, (2) subducted sediments that produced an enriched isotopic signature in the Soná-Azuero arc and ChagresBayano arc, and (3) a Galápagos-plume type source, which is strongly manifest in the Adakite suite and of only minor significance for the Chagres-Bayano arc and Cordilleran arc magma sources. An additional ${ }^{87}$ Sr-enriched component (4) is 
recognized that reflects a seawater contribution to Adakite suite magmagenesis and hydrothermal alteration of the other age groups after their emplacement. A ubiquitous slab-derived LILE-enriched and HFSE-depleted fluid is present in all rocks.

\subsubsection{Changing Mantle Sources through Time}

Initial Caribbean large igneous province magmatism was derived from a plume mantle source and resulted in the thickening of the Caribbean oceanic crust over a period of $\sim 25$ million years from $\sim 95$ to $71 \mathrm{Ma}$ (Hoernle et al., 2004). The second, Chagres-Bayano arc phase of magmatism from 66 to 42 Ma was generated within a subduction-modified depleted mantle source. Significant amounts of oceanic sediment were subducted and mixed into this depleted mantle during the initiation of the Panama arc. The earliest Soná-Azuero arc (71-68 Ma) samples are still geochemically distinct in this scenario. They display trace element characteristics that more closely resemble the OIB-like Caribbean large igneous province basement than the rocks of Chagres-Bayano arc (Figs. 5.7 and 5.8), because they are less depleted in radiogenic isotope character than Chagres-Bayano arc samples. Because the Soná-Azuero arc represents the transition from plume activity at the Galápagos hotspot to subduction, the mantle wedge at that time may still have contained a component of enriched Caribbean large igneous province mantle, but also had a significant contribution from subducted sediments. This idea is supported by Buchs et al. (2007), who found arc rocks on the Azuero peninsula with REE compositions similar to the composition of the Caribbean large igneous province plateau. They concluded that these proto-arc magmas were derived from the subplateau lithospheric mantle. During Chagres-Bayano arc time (66-42 Ma), the mantle source producing arc magmas was still immature and compositionally variable, possibly reflecting the progressive establishment and progressive maturation of the arc system by variable compositions of mantle wedge and sediment components. After a significant temporal gap in arc magmatic activity, the Cordilleran arc lavas erupted from 19 to $7 \mathrm{Ma}$ (our new Ar-Ar ages) and reflect a less depleted mantle source compared to that which produced the Chagres-Bayano arc magmas. The final Adakite suite phase of magmatism during the past 2 million years is distinct because magma generation is largely independent of mantle wedge composition. Adakite suite magmas likely formed by melting the leading edge of the subducted Cocos Ridge and older Caribbean large igneous province basement, either at the margin of 
a slab window or after slab breakoff below west-central Panama (Johnston \& Thorkelson, 1997; Abratis and Wörner, 2001).

Initiation of arc magmatism $\sim 70 \mathrm{Ma}$, at the same time as formation of the Galápagos plateau ended, removes the structural problem of forming Galápagos-plateau rocks on the Caribbean side of the proto-Central American arc. It was this issue that led Pindell et al. (2006) to argue against a link between the Galápagos hotspot and the thickened Caribbean plate. This temporal coincidence may, in fact, suggest a causal link.

The change in magma source character from Chagres-Bayano arc to Cordilleran arc magmatism, defined by trace element composition, is mostly a trajectory toward a more evolved parental magma composition. This could indicate increased mixing and homogenisation of sub-arc magma sources with time and/or the replacement of the mantle wedge by homogeneous, relatively undepleted asthenospheric mantle. The breakup of the Farallon plate at $\sim 25 \mathrm{Ma}$ (Lonsdale, 2005) which preceded the onset of the Cordilleran arc (22-19 Ma) may have been the trigger for these changes. The newly established Cocos-Nasca spreading center led to a change in mantle dynamics, for example upwelling in the region below the new ridge. The direction of plate movement also changed between 22.7 and $19.5 \mathrm{Ma}$, from mainly westward for the Farallon plate to northwest for the Cocos plate and southwest for the Nazca plate (Barckhausen et al. 2008). This rearrangement in relative plate motions caused the changes in mantle source after the brea up. We note that these changes are partly coincident to gaps in the magmatic activity and probably occurred relatively rapidly. This suggests that mantle source changes may have been triggered forcibly by the rearrangement of the plate tectonic setting and that the mantle wedge must have been relatively mobile in responding to these dynamic changes of plate configurations.

\subsection{CONCLUSIONS}

A mantle source composed of the old Caribbean large igneous province source and variable degrees of a mixed-plume source is inferred for the Soná-Azuero arc, which represents the switch from island arc volcanism to subduction zone magmatism, with arc magmatism in the region of the Azuero and Soná peninsulas of Panama commencing as early as $71 \mathrm{Ma}$. The developing arc then migrated eastward into the Chagres- Bayano region of central Panama east of the Panama Canal. During this 
time, magmas were derived from a variably-depleted subarc mantle source. Subsequently, as the arc system matured, the subarc mantle source evolved toward a slightly more homogeneous and less depleted state. The two phases of ChagresBayano arc of magmatism, from 66.4 to $61.5 \mathrm{Ma}$ and from 49.4 to $41.6 \mathrm{Ma}$, are both distinct in terms of ${ }^{206} \mathrm{~Pb} /{ }^{204} \mathrm{~Pb}$ isotope ratios from the earlier Soná-Azuero arc magmatism. This heterogeneous mantle source for Chagres-Bayano arc magmatism consisted of a mixture of depleted mantle and enriched crustal components, most likely derived from variable amounts of subducted marine pelagic sediments and subduction fluids. After a temporal lull of some 20 million years, the Cordilleran arc stage of magmatism commenced at 19.2 Ma and lasted until 6.8 Ma (our new $\mathrm{Ar}-\mathrm{Ar}$ ages). The mantle source at this time was similar in composition to that which is presently generating magmas below the active Central American arc to the west in Costa Rica. This mantle source for this magmatism was less depleted in composition and tended to produce magmas of a more homogeneous intermediate composition. The difference between Chagres-Bayano arc and Cordilleran arc source compositions reflects a maturation of the subarc mantle as indicated by increased mixing and homogenization of subarc magma sources through time and/or the replacement of the mantle wedge by a homogeneous and relatively undepleted asthenospheric mantle source. For the most recent Adakite suite magmatism in western and central Panama (<2 Ma), an origin is envisioned from partial melts of seawater altered subducted basaltic oceanic crust derived from the Galápagos hotspot mantle.

Changes in subduction style and resultant variations in magma sources are attributed to dynamic changes in regional tectonics over the ast 100 million years. The initiation of Soná-Azuero arc magmatism partly overlaps in time the cessation of the high plume activity at the Galápagos hotspot. The change from Chagres-Bayano arc to Cordilleran arc magmatism was likely triggered by the breakup of the Farallon plate at $25 \mathrm{Ma}$. Changes in contributing mantle sources appear to be relatively abrupt, indicating that the mantle source in the subduction wedge may have been moved forcibly by these plate rearrangements. Adakite suite magmatism was only possible because of slab window formation and accompanied melting of Caribbean large igneous province basement components or Cocos Ridge OIB by intensive slab hydration. 


\subsection{ACKNOWLEDGEMENTS}

We thank the following organizations and people for their logistical assistance and help in collection of samples across Panama from 2001 to 2006: Thomas Exenberger and Thomas Jakits of Helipan Panama; Lance Vander Zyl of U.S. Army Yuma Proving Ground Tropic Regions Test Center; Eric Nicolaisen, Ricardo Martinez, and Alonso Iglesias of TRAX Evalución Ambiental, S.A. The Volcan Barú samples were collected and partially analyzed by S. Rausch as a part of her Master's thesis at Göttingen University. G. Hartmann, R. Przybilla. I. Reuber, I. Schönberg, and K. Simon assisted with geochemical and isotopic analytical work. We thank B. Hansen and A. Pack for access to the thermal ionization mass spectrometer and stable isotope laboratories. Financial support for the fieldwork came from an Army Researge Laboratory fellow stipend to R.S.H. and from the Deutsche Forschungsgemeinschaft project WO 362/27-2 to G.W. Constructive comments by K. Hoernle and E. Gazel are greatly appreciated.

\subsection{REFERENCES CITED}

Abratis M., 1998, Geochemical variations in magmatic rocks from southern Costa Rica as a consequence of Cocos Ridge subduction and uplift of the Cordillera de Talamanca [PhD-thesis]: University of Göttingen, 144p.

Abratis, M., and Wörner, G., 2001, Ridge collision, slabwindow formation, and the flux of Pacific asthenosphere into the Caribbean realm: Geology, v. 29, p. 127130.

Alvarado, G. E., Kussmaul, S., Chiesa, S., Gillot, P. Y., Appel, H., Wörner, G., and Rundle, C., 1992, Resumen cronoestratigráfico de las rocas ígneas de Costa Rica basado en dataciones radiométricas: Journal of South American Earth Sciences, v. 6, p. 151-168.

Alvarado, G. E., Denyer, P., and Sinton, C. W., 1997, The 89 Ma Tortugal komatiitic suite, Costa Rica: Implications for a common geological origin of the Caribbean and Eastern Pacific region from a mantle plume: Geology, v. 25, p. 439-442.

Barckhausen, U., Ranero, C. R., Cande, S. C., Engels, M., and Weinrebe, W., 2008, Birth of an intraoceanic spreading center: Geology, v. 36, np. 767-770.

Bindeman, I. N., Ponomareva, V. V., Bailey, J. C., and Valley, J. W., 2004, Volcanic arc of Kamchatka: a province with high-[delta]180 magma sources and largescale 180/160 depletion of the upper crust: Geochimica et Cosmochimica Acta, v. 68, p. 841-865.

Bindeman, I. N., Eiler, J. M., Yogodzinski, G. M., Tatsumi, Y., Stern, C. R., Grove, T. L., Portnyagin, M., Hoernle, K., and Danyushevsky, L. V., 2005, Oxygen isotope evidence for slab melting in modem and ancient subduction zones: Earth and Planetary Science Letters, v. 235, no. 3-4, p. 480-496. 
Buchs, D. M., Baumgartner, P. O., and Arculus, R., 2007, Late Cretaceous arc initiation on the edge of an oceanic plateau (South Central America): American Geophysical Union, Fall Meeting 2007, abstract T13C-1468.

Carr, M., Feigenson, M., Patino, L., and Walker, J., 2003, Volcanism and geochemistry in Central America; progress and problems, in Eiler, J. M., ed., Inside the Subduction Factory: American Geophysical Union, Geophysical Monograph Series, v. 133, p. 153-174.

Cerling, T. E., Brown, F. H., and Bowman, J. R., 1985, Low-temperature alteration of volcanic glass: hydration, $\mathrm{Na}, \mathrm{K},{ }^{18} \mathrm{O}$ and Ar mobility: Chemical Geology, v. 52, p. 281-293.

Chaco, T., Cole, D. R., and Horita, J, 2001, Equilibrium oxygen, hydrogen, and carbon isotope fractionation factors applicable to geologic systems: Reviews in Mineralogy and Geochemistry, v. 43, p. 1-81

Chiba, H., Chacko, T., Clayton, R. N., and Goldsmith, J. R., 1989, Oxygen isotope fractionations involving diopside, forsterite, magnetite and calcite: Application of geothermometry: Geochimica et Cosmochimica Acta, v. 53, p. 2985-2995.

Christie, D. M., Duncan, R. A., McBirney, A. R., Richards, M. A., White, W. M., Harpp, K. S., and Fox, C. G., 1992, Drowned islands downstream from the Galápagos hotspot imply extended speciation times: Nature, v. 355, p. 246248.

Coates, A. G., Jackson, J. B. C., Collins, L. S., Cronin, T. M., Dowsett, H. J., Bybell, L. M., Jung, P., and Obando, J. A., 1992, Closure of the Isthmus of Panama: The near-shore marine record of Costa Rica and western Panama: Geological Society of America Bulletin, v. 104, p. 814-828.

Coates, A., Aubry, M., Berggren, W., and Collins, L., 2000, New evidence for the earliest stages in the rise of the Isthmus of Panama from Bocas del Toro, Panama: Geological Society of America, 2000 annual meeting Abstracts with Program, v. 32, p. A-146.

Collins, L. S., Coates, A. G., Berggren, W. A., Aubry, M.-P., and Zhang, J., 1996, The late Miocene Panama isthmian strait: Geology, v. 24, p. 687-690.

de Boer, J. Z., Defant, M. J., Stewart, R. H., Restrepo, J. F., Clark, L. F., and Ramirez, A. H., 1988, Quaternary calc-alkaline volcanism in western Panama: Regional variation and implication for the plate tectonic framework: Journal of South American Earth Sciences, v. 1, p. 275-293.

de Boer, J. Z., Defant, M. J., Stewart, R. H., and Bellon, H., 1991, Evidence for active subduction below western Panama: Geology, v. 19, p. 649-652.

de Boer, J., Drummond, M., Bordelon M. J., Defant M. J., Bellon H, and Maury, R.C. 1995, Cenozoic magmatic phases of the Costa Rican island arc (Cordillera de Talamanca): in Mann, P., ed., Geologic and Tectonic Development of the Caribbean Plate Boundary in Southern Central America, Geological Society of America Special Paper 262, p. 35-55.

Defant, M. J. and Drummond, M. S., 1990, Derivation of some modern arc magmas by melting of young subducted lithosphere: Nature, v. 347, p. 662-665.

Defant, M., Clark, L., Stewart, R., Drummond, M., de Boer, J., Maury, R., Bellon, H., Jackson, T., and Restrepo, J., 1991a, Andesite and dacite genesis via 
contrasting processes: the geology and geochemistry of El Valle Volcano, Panama: Contributions to Mineralogy and Petrology, v. 106, p. 309-324.

Defant, M. J., Richerson, P. M., De Boer, J. Z., Stewart, R. H., Maury, R. C., Bellon, H., Drummond, M. S., Feigenson, M. D., and Jackson, T. E., 1991b, Dacite Genesis via both Slab Melting and Differentiation: Petrogenesis of La Yeguada Volcanic Complex, Panama: Journal of Petrology, v. 32, p. 11011142.

Defant, M. J., Jackson, T. E., Drummond, M. S., De Boer, J. Z., Bellon, H., Feigenson, M. D., Maury, R. C., and Stewart, R. H., 1992, The geochemistry of young volcanism throughout western Panama and southeastern Costa Rica: an overview: Journal of the Geological Society, v. 149, no. 4, p. 569-579.

Dorendorf, F., Wiechert, U., and Worner, G., 2000, Hydrated sub-arc mantle: a source for the Kluchevskoy volcano, Kamchatka/Russia: Earth and Planetary Science Letters, v. 175, p. 69-86.

Drummond, M. S., Bordelon, M., de Boer, J. Z., Defant, M. J., Bellon, H., and Feigenson, M. D., 1995, Igneous petrogenesis and tectonic setting of plutonic and volcanic rocks of the Cordillera de Talamanca, Costa Rica-Panama, Central American arc: American Journal of Science, v. 295, p. 875-919.

Duncan, R.A. and Hargraves, R.B., 1984, Plate tectonic evolution of the Carribbean region in the mantle reference frame: in Bobini, W. E., Hargraves, R. B., and Shagam, R., eds., The Caribbean Plate Boundary and Regional Tectonics, Geological Society of America, Memoroir162, p. 81-93.

Duque-Caro, H., 1990, The choco block in the northwestern corner of South America: Structural, tectonostratigraphic, and paleogeographic implications: Journal of South American Earth Sciences, v. 3, p. 71-84.

Eiler, J. M., Farley, K. A., Valley, J. W., Hofmann, A. W., and Stolper, E. M., 1996, Oxygen isotope constraints on the sources of Hawaiian volcanism: Earth and Planetary Science Letters, v. 144, no. 3-4, p. 453-467.

Eiler, J. M., Farley, K. A., Valley, J. W., Hauri, E., Craig, H., Hart, S. R., and Stolper, E. M., 1997, Oxygen isotope variations in ocean island basalt phenocrysts: Geochimica et Cosmochimica Acta, v. 61, p. 2281-2293.

Eiler, J. M., Grönvold, K., and Kitchen, N., 2000, Oxygen isotope evidence for the origin of chemical variations in lavas from Theistareykir volcano in Iceland's northern volcanic zone: Earth and Planetary Science Letters, v. 184, p. 269286.

Feigenson, M. D., Carr, M. J., Maharaj, S. V., Juliano, S., and Bolge, L. L., 2004, Lead isotope composition of Central American volcanoes: Influence of the Galápagos plume: Geochemistry Geophysics Geosystems, v. 5, Q06001, doi: 10.1029/2003GC000621

Fisher S.P. and Pessagno E.A., 1965, Upper Cretaceous strata of northwestern Panama: American Association of Petroleum Geologists Bulletin, v. 49, p. 433444

Gazel, E., Carr, M. J., Hoernle, K., Feigenson, M. D., Szymanski, D., Hauff, F., van den Bogaard, P., 2009, Galápagos-OIB signature in southern Central America: Mantle refertilization by arc-hot spot interaction:Geochemistry Geophysics Geosystems, v. 10, Article Number: Q02S11 
Goossens, P. J., Rose, W. I. J., and Flores, D., 1977, Geochemistry of tholeiites of the Basic Igneous Complex of northwestern South America: Geological Society of America Bulletin, v. 88, p. 1711-1720.

Gregory, R. T., Criss, R. E., and Taylor, H. P., 1989, Oxygen isotope exchange kinetics in mineral pairs in closed and open systems: application to problems of hydrothermal alteration and Precambrian Iron Formations: Chemical Geology, v. 75, p. 1-42.

Harmon, R. S., Hoefs, J., and Wedepohl, K.-H., 1987, Stable isotope (O, H, S) relkationships in Tertiary basalts and their mantle xenoliths from the Northern Hessian Depression, W. Germany: Contributions to Mineralogy and Petrology, v. 95 , p. $350-369$.

Harmon, R. S. and Gerbe, M.-C., 1992, The 1982-83 eruption at Galunggung Volcano, Java (Indonesia): Oxygen isotope geochemistry of a chemically zoned magma chamber: Journal of Petrology, v. 33, p. 585-609.

Hauff, F., Hoernle, K., Schmincke, H. U., and Werner, R., 1997, A Mid Cretaceous origin for the Galápagos hotspot: volcanological, petrological and geochemical evidence from Costa Rican oceanic crustal segments: Geologische Rundschau, v. 86, p. 141-155.

Hauff, F., Hoernle, K., van den Bogaard, P., Alvarado, G., and Garbe-Schönberg, D., 2000a, Age and geochemistry of basaltic complexes in western Costa Rica: Contributions to the geotectonic evolution of Central America: Geochemistry, Geophysics, Geosystems, v. 1, 1009, doi:10.1029/1999GC000020

Hauff, F., Hoernle K., Tilton, G., Graham, D., Kerr, A.C., 2000b, Large volume recycling of oceanic lithosphere over short time scales: geochemical constraints from the Caribbean Large Igneous Province: Earth and Planetary Science Letters, v. 174, p. 247-263.

Haug, G. H. and Tiedemann, R., 1998, Effect of the formation of the Isthmus of Panama on Atlantic Ocean thermohaline circulation: Nature, v. 393, p. 673676.

Haug, G. H., Tiedemann, R., Zahn, R., and Ravelo, A. C., 2001, Role of Panama uplift on oceanic freshwater balance: Geology, v. 29, no. 3, p. 207-210.

Heinrichs, H., and Herrmann, A. G., 1990, Praktikum der analytischen Geochemie, Springer-Lehrbuch: Berlin, Springer-Verlag, 669p.

Hoernle, K., Werner, R., Morgen, J. P., Garbe-Schönberg, D., Bryce, J., and Mrazek, J., 2000, Existence of complex spatial zonation in the Galápagos plume: Geology, v. 28, p. 435-438.

Hoernle, K., van den Bogaard, P., Werner, R., Lissinna, B., Hauff, F., Alvarado, G., and Garbe-Schönberg, D., 2002, Missing history (16-71 Ma) of the Galápagos hotspot: Implications for the tectonic and biological evolution of the Americas: Geology, v. 30, p. 795-798.

Hoernle, K., Hauff, F., and van den Bogaard, P., 2004, 70 m.y. history (139-69 Ma) for the Caribbean large igneous province: Geology, v. 32, p. 697-700.

Hoernle, K., and Hauff, F., 2007, Oceanic Igneoous Complexes in Bundschuh, J., and Avarado, G., eds., Central America: Geology, Resources and Hazards: Lisse, Swets \& Zeitlinger, p. 523-547. 
Hoernle, K., Abt, D. L., Fischer, K. M., Nichols, H., Hauff, F., Abers, G. A., van den Bogaard, P., Heydolph, K., Alvarado, G., Protti, M., and Strauch, W., 2008, Arc-parallel flow in the mantle wedge beneath Costa Rica and Nicaragua: Nature, v. 451, p. 1094-1097.

Ionov, D. A., Harmon, R. S., France-Lanord, C., Greenwood, P. B., and Ashchepkov, I. V., 1994, Oxygen isotope composition of garnet and spinel peridotites in the continental mantle: Evidence from the Vitim xenolith suite, southern Siberia: Geochimica et Cosmochimica Acta, v. 58, p. 1463-1470.

Johnston, S. T., and Thorkelson, D. J., 1997, Cocos-Nazca slab window beneath Central America: Earth and Planetary Science Letters, v. 146, p. 465-474.

Kay, R. W., 1978, Aleutian magnesian andesites: melts from subducted Pacific ocean crust: Journal of Volcanology and Geothermal Research, v. 4, p. 117132.

Kerr, A. C., Marriner, G. F., Tarney, J., Nivia, A., Saunders, A. D., Thirlwall, M. F., and Sinton, C. W., 1997, Cretaceous Basaltic terranes in Western Columbia: Elemental, chronological and Sr-Nd isotopic constraints on petrogenesis: Journal of Petrology, v. 38, p. 677-702.

Kerr, A. C., Tarney, J., Kempton, P. D., Spadea, P., Nivia, A., Marriner, G. F., and Duncan, R. A., 2002, Pervasive mantle plume head heterogeneity: Evidence from the late Cretaceous Caribbean-Colombian oceanic plateau: Journal of Geophysical Research, v. 107, doi:10.1029/2001JB000790.

Kesler, S. E., Sutter, J. F., Issigonis, M. J., Jones, L. M., and Walker, R. L., 1977, Evolution of porphyry copper mineralization in an oceanic island arc; Panama: Economic Geology, v. 72, p. 1142-1153.

Kieffer, S. W., 1982, Thermodynamics and lattice-vibrations of minerals: 5. Applications to phase equilibria, isotope fractionation and hiht-pressure termodynamic properties: Reviews of Geophysics, v. 20, p. 827-849.

Lapierre, H., Dupuis, V., de Mercier, L. B., Bosch, D., Monie, P., Tardy, M., Maury, R. C., Hernandez, J., Polve, M., Yeghicheyan, D., and Cotten, J., 1999, Late Jurassic Oceanic Crust and Upper Cretaceous Caribbean Plateau Picritic Basalts Exposed in the Duarte Igneous Complex, Hispaniola: A Reply: Journal of Geology, v. 107, p. 509-512.

Le Maitre, R. W., Bateman, P., Dudek, A., Keller, J., Lemeyre J., Le Bas, M., Sabine, P., Schmid, R., Sorensen, H., Streckeisen, A., Wooley, A., and Zanettin, B., 1989, A classification of igneous rocks and glossary of terms: Oxford, Blackwell Publishing, 193 p.

Lissinna, B., Hoernle, K., Hauff, F., van den Bogaard, P., Sadofsky, S., 2006, The Panamanian island arc and Galápagos hotspot: A case study fort he long-term evolution of arc/hotspot interaction, Geophysical Research Abstracts, Copernicus Group.

Lonsdale, P., and Klitgord, K. D., 1978, Structure and tectonic history of the eastern Panama Basin: Geological Society of America Bulletin, v. 89, p. 981-999.

Lonsdale, P., 2005, Creation of the Cocos and Nazca plates by fission of the Farallon plate: Tectonophysics, v. 404, p. 237-264. 
MacMillan, I., Gans, P. B., Alvarado-Induni, G. E., 2004, Middle Miocene to present plate tectonic history of the southern Central American Volcanic Arc. Tectonophysics, v. 392, p. 325-348.

Mann, P. and Kolarsky, R., 1995, East Panama deformed belt; structure, age, and neotectonic significance: in Mann, P., ed., Geologic and Tectonic Development of the Caribbean Plate Boundary in Southern Central America, Geological Society of America Special Paper 262, p. 111-130.

Matsuhisa, Y., 1979, Oxygen isotopic compositions of volcanic rocks from the east Japan island arcs and their bearing on petrogenesis: Journal of Volcanology and Geotehrmal Research, v. 5, p. 271-296.

Mattey, D., Lowry, D., and Macpherson, C., 1994, Oxygen isotope composition of mantle peridotite: Earth and Planetary Science Letters, v. 128, p. 231-241.

Matthews, A. Goldsmith, J. R., and Clayton, R. N., 1983, Oxygen isotope fractionations involving pyroxenes: The calibration of mineral pari geothermometers: Geochimica Cosmochimica Acta, v. 47, p. 631-644.

Maury, R. C., Defant, M. J., Bellon, H., de Boer, J. Z., Stewart, R. H., C., and Cotton, J., 1995, Early Tertiary arc volcanics from eastern Panama: in Mann, P., ed., Geologic and Tectonic Development of the Caribbean Plate Boundary in Southern Central America, Geological Society of America Special Paper 295, p. 29-34.

Meschede, M., and Frisch, W., 1998, A plate-tectonic model for the Mesozoic and Early Cenozoic history of the Caribbean plate: Tectonophysics, v. 296, no. 34, p. $269-291$.

Muehlenbachs, K. And Clayton, R.N., 1972, Oxygen isotope studies of fresh and weatherd submarine basalts: Canadian Journal of Earth Science, 9: 471-479.

Pack, A., Toulouse, C., and Przybilla, R., 2007, Determination of oxygen triple isotope ratios of silicates without cryogenic separation of NF3-technique with application to analyzes of technical $\mathrm{O}_{2}$ gas and meteorite classification: Rapid Communications in Mass Spectrometry, v. 21, p. 3721-3728.

PetDB (Petrological Database of the Ocean Floor), 2008, http://www.petdb.org/petdbWeb/search/download_pg.jsp, online source.

Pindell, J., Kennan, L., Maresch, M. W., Stanek, K. P., Draper, G., and Higgs, R., 2005, Plate-kinematics and crustal dynamics of circum-Caribbean arccontinent interactions: Tectonic controls an basin development in ProtoCaribbean margins, in Lallemant, H. G. A., and Sisson, V. B., eds., CaribbeanSouth American Plate Interactions, Venezuela, Geological Society of America, Special paper 394, p. 7-52.

Pindell, J., Kennan, L., Stanek, K. P., Maresch, M. W., and Draper G., 2006, Foundations of Gulf of Mexico and Caribbean evolution: eight controversies resolved: Geological Acta, v. 4, p. 303-341.

Plank, T., and Langmuir, C. H., 1998, The chemical composition of subducting sediment and its consequences for the crust and mantle: Chemical Geology, v. 145 , p. $325-394$.

Recci, J., 1975, Paleografia Atlas Nacional de Panamá:Instituto Geografico Nacional "Tommy Guardia", 128 p. 
Renne, P. R., Swisher, C. C., Deino, A. L., Karner, D. B., Owens, T. L., and DePaolo, D. J., 1998, Intercalibration of standards, absolute ages and uncertainties in ${ }^{40} \mathrm{Ar} /{ }^{39} \mathrm{Ar}$ dating: Chemical Geology, v. 145, p. 117-152.

Revillon, S., Arndt, N. T., Chauvel, C., and Hallot, E., 2000, Geochemical study of ultramafic volcanic and plutonic rocks from Gorgona Island, Colombia: The plumbing system of an oceanic plateau: Journal of Petrology, v. 41, no. 7, p. 1127-1153.

Reynaud, C., Jaillard, É., Lapierre, H., Mamberti, M., and Mascle, G. H., 1999, Oceanic plateau and island arcs of southwestern Ecuador: their place in the geodynamic evolution of northwestern South America: Tectonophysics, v. 307, p. 235-254.

Rickwood, P. C., 1989, Boundary lines within petrologic diagrams which use oxides of major and minor elements: Lithos, v. 22, no. 4, p. 247-263.

Sadofsky, S., Hoernle, K., Duggen, S., Hauff, F., Werner, R. Garbe-Schönberg, D., 2009, Geochemical variations in the Cocos Plate subducting beneath Central America : implications for the composition of arc volcanism and the extent of the Galápagos Hotspot influence on the Cocos oceanic crust: International Journal of Earth Sciences, v. 98, p. 901-913.

Sharp, Z. D., 1990, A laser-based microanalytical method for the in situ determination of oxygen isotope ratios of silicates and oxides: Geochimica et Cosmochimica Acta, v. 54, p. 1353-1357.

Sinton, C. W., Christie, D. M., and Duncan, R. A., 1996, Geochronology of Galápagos seamounts: Journal of Geophysical Research, v. 101, p. 1368913700.

Sinton, C. W., Duncan, R. A., and Denyer, P., 1997, Nicoya Peninsula, Costa Rica: A single suite of Caribbean oceanic plateau magmas: Journal of Geophysical Research, v. 102, p. 15507-15520.

Sinton, C. W., Duncan, R. A., Storey, M., Lewis, J., and Estrada, J. J., 1998, An oceanic flood basalt province within the Caribbean plate: Earth and Planetary Science Letters, v. 155, p. 221-235.

Smith, M. E., Singer, B. S., Carroll, A. R., and Fournelle, J. H., 2006, High-resolution calibration of Eocene strata: ${ }^{40} \mathrm{Ar} /{ }^{39} \mathrm{Ar}$ geochronology of biotite in the Green River Formation: Geology, v. 34, p. 393-396.

Steiger, R. H., and Jäger, E., 1977, Subcommission on geochronology: Convention on the use of decay constants in geo- and cosmochronology: Earth and Planetary Science Letters, v. 36, p. 359-362.

Stern, C. R. and Kilian, R., 1996, Role of the subducted slab, mantle wedge, and continental crust in the generation adakites from the Andean Austral volcanic zone: Contributions to Mineralogy and Petrology, v. 123, p. 263-281.

Sun, S. S., and McDonough, W. F., 1989, Chemical and isotopic systematics of oceanic basalts: implications for mantle composition and processes: Geological Society, London, Special Publications, v. 42, p. 313-345.

Taylor, H. P., Turi, B., and Cundari, A., $1984,{ }^{18} \mathrm{O} /{ }^{16} \mathrm{O}$ and chemicval relationships in K-rich volcanic rocks from Australia, East Africa, Antarctica, and San Venanzo Cupaello, Italy: Earth and Planetary Science Letters, v. 69, p. 263-276. 
Weyl, R., 1980, Geology of Central America (2 ${ }^{\text {nd }}$ edition): Berlin-Stuttgart, Gebrueder Borntraeger, $371 \mathrm{p}$.

White, W. M., McBirney, A. R., and Duncan, R. A., 1993, Petrology and geochemistry of the Galápagos Islands: Portrait of a pathological mantle plume: Journal of Geophysical Research, v. 98, p. 19533-19563.

Wörner, G., Harmon, R., Hartmann, G., and Simon, K., 2005, Igneous geology and geochemistry of the Upper Río Chagres Basin, in Harmon, R. S., ed., The Río Chagres, Panama: A Multidisciplinary Profile of a Tropical Watershed, Springer, Amsterdam p. 65-81.

Wörner, G., Harmon, R. S., and Wegner, W., 2009, Geochemical evolution of igneous rock and changing Magma Sources during the Evolution and Closure of the Central American Landbridge, in S. M. Kay, V. A. Ramos, and Dickinson, W. R., eds., Backbone of the Americas: Shallow Subduction, Plateau Uplift, and Ridge and Terrane Collision:, Geological Society of America Memoir 204, p. 183-196.

Zheng, Y.-F., 1991, Calculation of oxygen isotope fractionation in metal oxides: Geochimica et Cosmochimica Acta, v. 55, p. 2299-2307.

Zheng, Y.-F., 1997, Prediction of high-temperature oxygen isotope fractionation factors between mantle minerals: Physics and Chemistry of Minerals, v. 24, p. 356-364.

Zhou, Z.-F. and Zheng, Y.-F., 2003, Calculation of O-isotope fractionation in magmatic rocks: Chemical Geology, v. 193, p. 59-80.

Zindler, A., and Hart, S., 1986, Chemical geodynamics: Annual Review of Earth and Planetary Sciences, v. 14, p. 493-5. 
Chaviser (5)

Conclusions 


\subsection{CONCLUSIONS}

Based on major and trace elements, $\mathrm{Sr}-, \mathrm{Nd}-, \mathrm{Pb}-$, and O-isotopes, ${ }^{40} \mathrm{Ar} /{ }^{39} \mathrm{Ar}$ dating and petrographic investigations the following conclusions for the evolution of the Central American landbridge in Panama can be drawn:

1. Taking the Chagres igneous complex (CHICO) as an example it is shown that even with strong petrographic evidence for alteration and new growth of minerals, the compositional and isotopic systematics are changed relatively little. This leads creditability to the interpretation of changing mantle sources based on trace element pattern and $\mathrm{Pb}-, \mathrm{Nd}-, \mathrm{Sr}$ - and $\mathrm{O}$ - isotopes.

2. Alteration in the $\mathrm{CHICO}$ is characterized by a primary high temperature hydrothermal alteration followed by a subsequent second low temperature hydrothermal event which partly reset the changes of the former alteration. The low temperature event is subdivided into a group with low fluid/rock ratio and high seawater/rock ratio.

3. The alteration potential of the CHICO rocks is less pronounced than for mid ocean ridges and ocean island settings. The high magma production rate leads to the formation of thick stacks of sheet flows which offer only limited fluid pathways compared to settings with lower eruption rates like OIB seamounts. These ocean islands are dominantly composed of pillows and breccias which provide numerous fluid pathways. Therefore even massive submarine volcanism of the CHICO type would not lead to extensive exchanges between magmatic rocks and seawater.

4. The geologic evolution of Panama can be divided into five stages: (1) emergence of a genetically complex basement prior to $71 \mathrm{Ma}$, (2) initiation of the Soná-Azuero arc (3) formation of the Chagres-Bayano arc (4) development of the Cordilleran arc (5) localized Adakite volcanism.

5. Stage 1: Two distinct trace element signatures are recognized in the oldest (< $95 \mathrm{Ma}$ and > $71 \mathrm{Ma}$ ) basement rocks: (a) flat trace-element patterns in oceanic basement of the Caribbean large igneous province (CLIP), and (b) enriched OIB signatures in CLIP terranes. The mantle source involved in CLIP magmatism is related to the Galápagos plume (Fig. 6.1A). 
(A) > 71 Ma Pre-arc

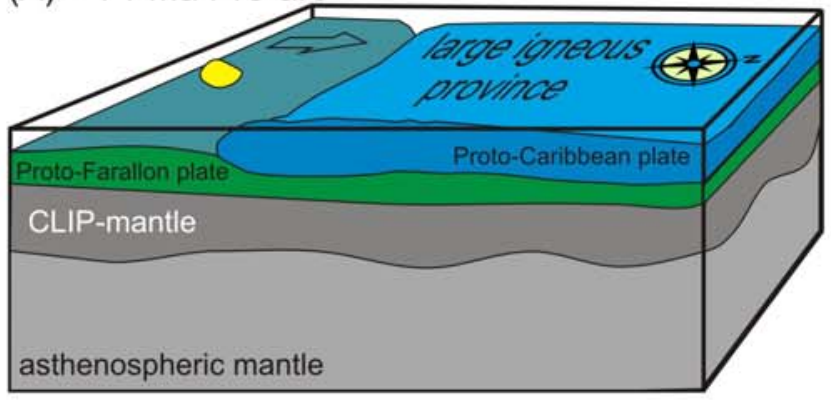

(B) 71-68 Ma Soná-Azuero arc

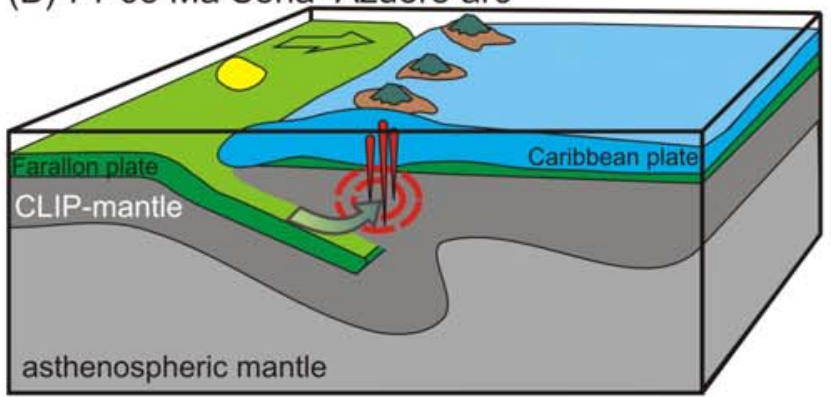

(C) 66-41 Ma Chagres-Bayano arc

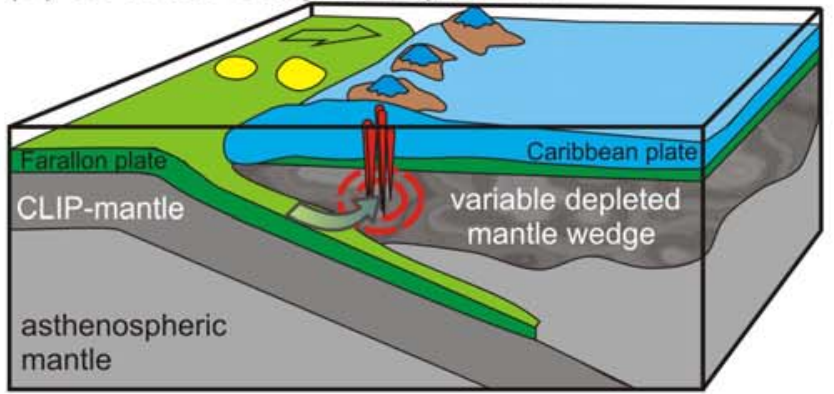

(D) 19-7 Ma Cordilleran arc

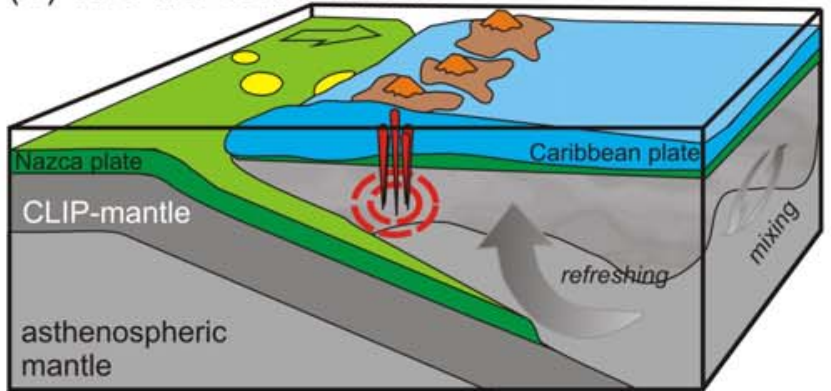

(E) $<2$ Ma adakite suite

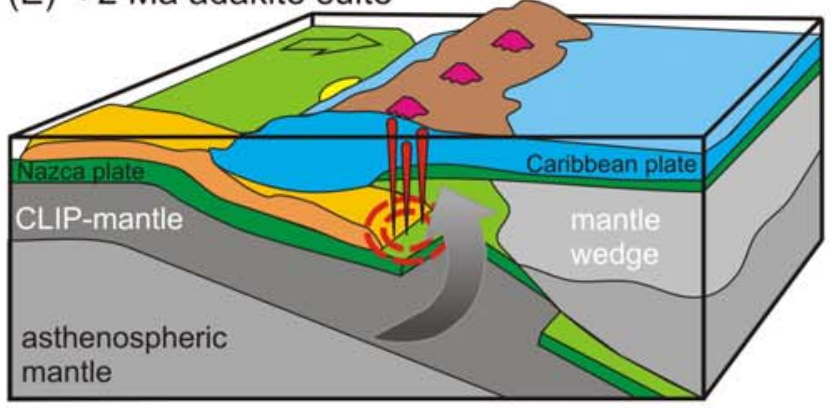

Figure 6.1. Schematic sketch of the arc evolution of south Central America between the Late Cretaceous and today. 
6. Stage 2: The Soná-Azuero arc represents the switch from island arc volcanism to subduction zone magmatism commencing as early as $71 \mathrm{Ma}$ showing a mantle source composed of the old Caribbean large igneous province source and variable degrees of a mixed-plume mantle (Fig. 6.1B).

7. Stage 3: The Chagres-Bayano arc is characterized by two phases from 66 to $61 \mathrm{Ma}$ and from 49 to $41 \mathrm{Ma}$. The heterogeneous mantle source for this arc magmatism consisted of a mixture of depleted mantle and enriched crustal components, most likely derived from variable amounts of subducted marine pelagic sediments, which evolved toward a slightly more homogeneous and less depleted state over time (Fig. 6.1C).

8. Stage 4: After a temporal lull of some 20 million years, the Cordilleran arc stage of magmatism commenced at $19 \mathrm{Ma}$ and lasted until $7 \mathrm{Ma}$. The mantle source for this magmatism was less depleted in composition and tended to produce magmas of a more homogeneous intermediate composition. This reflects a maturation of the subarc mantle as indicated by increased mixing and homogenization of the sources through time and/or the replacement of the mantle wedge by a homogeneous and relatively undepleted asthenospheric mantle source (Fig. 6.1D).

9. Stage 5: For the most recent Adakite suite magmatism in western and central Panama (<2 Ma), an origin is envisioned from partial melts of seawater altered subducted basaltic oceanic crust derived from the Galápagos hotspot mantle enabled by slab window formation (Fig. 6.1E).

10. Changes in subduction style and resultant variations in magma sources are attributed to dynamic changes in regional tectonics over the last $95 \mathrm{Ma}$. The initiation of Soná-Azuero arc magmatism partly overlaps in time the cessation of the high plume activity at the Galápagos hotspot. The change from Chagres-Bayano arc to Cordilleran arc magmatism was likely triggered by the breakup of the Farallon plate at $\sim 25 \mathrm{Ma}$. Adakite suite magmatism was only possible because of slab window formation and accompanied melting of Caribbean large igneous province basement components or Cocos Ridge OIB by intensive slab hydration. 


\section{Wencke Wegner}

*18. Oktober 1978 in Mannheim

\begin{tabular}{|c|c|c|}
\hline Abitur & 1998 & Otto-Hahn-Gymnasium Göttingen \\
\hline Studium & 1998-2004 & Studium an der Georg-August- Universität Göttingen \\
\hline Bachelor & Mai 2002 & $\begin{array}{l}\text { Titel der Bachelorarbeit: } \\
\text { "Kristallgrößenverteilung in El Misti Andesiten: eine C? } \\
\text { Studie" }\end{array}$ \\
\hline Diplom & Sept. 2004 & $\begin{array}{l}\text { Titel der Diplomarbeit: "Growth History of Sanidine } \\
\text { Crystals in Taapaca Dacites (Northern Chile)" }\end{array}$ \\
\hline Promotion & seit 2005 & $\begin{array}{l}\text { wissenschaftliche Mitarbeiterin an der Georg-August- } \\
\text { Universität Göttingen }\end{array}$ \\
\hline
\end{tabular}

Veröffentlichungen

Abstracts:

Wegner W, Wörner G, Kronz A (2005) Evolution of Taapaca Volcano, N.Chile: Evidence from major and trace elements, $\mathrm{Sr}-, \mathrm{Nd}-, \mathrm{Pb}$-isotopes, age dating and chemical zoning in sanidine megacrysts. Int. Sym. on Andean Geodynamics (2005)

Wegner W, Kronz A, Wörner G (2005) Growth history of sanidine crystals in Taapaca dacites (northern Chile). Lateinamerika Kolloquium 2005

Wörner G, Wegner W, Harmon RS, Hartmann G, Simon K, Singer B, Hora J (2006) Geochemical signatures in igneous rocks from Southern Costa Rica and Western Panama: Evidence for a maturing arc system and the effect of Cocos Ridge subduction. Backbone of the Americas 2006

Wegner W, Wörner G, Harmon RS, Hartmann G, Simon K, Singer B, Hora J (2007) Geochemical fingerprints in igneous rocks from Chagres Igneous Complex, Central Panama and Western Panama: Evolution of a maturing arc system. Lateinamerika Kolloquium 2007

Wegner W, Wörner G, Harmon RS, Simon K, Jicha B (2007) Evolution of a maturing arc system: The west-central Isthmus of Panama. Goldschmidt Conference 2007

Wegner W, Wörner G, Harmon RS, Jicha B (2009) Geochemical evolution of arc magmatism since Late Cretaceous of the Central American land-bridge. Lateinamerika Kolloquium 2009

Wegner W, Wörner G, Harmon RS, Jicha B (2009) Magmatic evolution and reconstruction of the Central American land-bridge since Late Cretaceous. EGU 2009

Wegner W, Banszak M , Kronz A, Wörner G (2009) Zoned sanidines in Taapaca dacites (II): Temperature, pressure and residence time. 2009 Annual Meeting of the Mineralogical Society of Great Britain and Ireland

\section{Publikationen:}

Wörner, G., Harmon, R. S., and Wegner, W., 2009, Geochemical evolution of igneous rock and changing Magma Sources during the Evolution and Closure of the Central American Landbridge, in S. M. Kay, V. A. Ramos, and Dickinson, W. R., eds., GSA Memoir, Backbone of the Americas: Shallow Subduction, Plateau Uplift, and Ridge and Terrane Collision: Boulder, Colorado, p. 183196.

Wegner, W., Wörner, G., Harmon, R. S., and Jicha, B. R., 2011, Magmatic history and evolution of the Central American Land Bridge in Panama since Cretaceous times: Geological Society of America Bulletin, v. 123, no. 3-4, p. 703-724. 


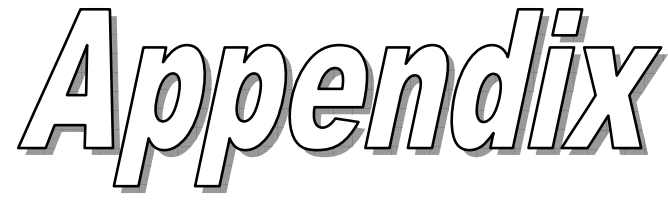

electronically provided on $C D$

I. Sample Regions Panama

II. Full Data Table

III. Complete Ar-results 